TIDES AND CURRENTS

IN

\title{
BOSTON HARBOR
}

PAUL SCHUREMAN
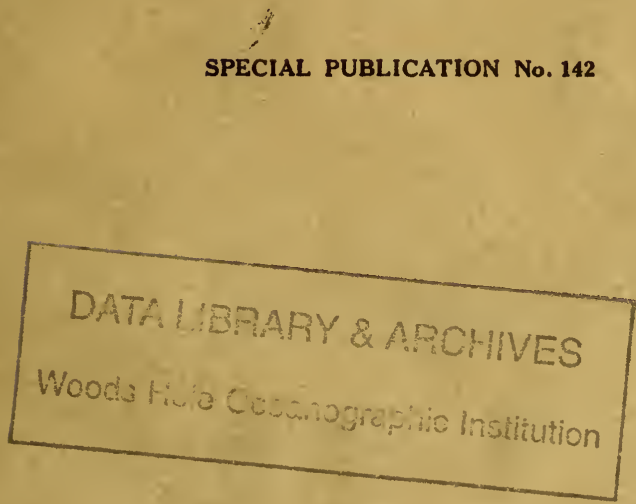

$G C$
309
186
55
1928

DEPARTMENT OF COMMERCE

U. S. COAST AND GEODETIC SURVEY

$\downarrow$ 



\title{
DEPARTMENT OF COMMERCE \\ U. S. COAST AND GEODETIC SURVEY \\ E. LESTER JONES, DIRECTOR
}

\section{TIDES AND CURRENTS}

IN

\section{BOSTON HARBOR}

\author{
BY \\ PAUL SCHUREMAN \\ Mathematician, U. S. Coast and Geodetic Survey
}

Special Publication No. 142

PRICE 30 CENTS

Sold only by the Superintendent of Documents, U. S. Government Printing Office Washington, D. C. 


\section{O N T E N T S}

Page

Introduction

Tide observations, Boston Navy Yard

Tide observations, Commonwealth Pier No. $5 \ldots \ldots \ldots$

Tide observations, miscellaneous series_........................ 18

Current observations, 1847 and $1848 \ldots \ldots \ldots \ldots \ldots \ldots \ldots \ldots$

Current observations, 1860,1861 , and $1863 \ldots$

Current observations, $1902 \ldots$

Current observations, $1926 \ldots$

Current observations, Boston Light Vessel

Summary of surface currents

Temperature and density observations._.

Tidal datums_...

Bench marks

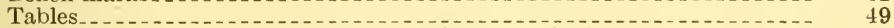

Appendix.-General characteristics of tides and tidal currents 98

List of publications relating to tides and currents by the Coast and Geodetic Survey

Index

\section{ILLCSTRATIONS}

1. Boston Harbor in 1775

2. Tide stations, Boston Harbor

3 . Annual variation in high water, Commonwealth Pier No. 5

4. Annual variation in low water, Commonwealth Pier No. $5 \ldots . .$.

5. Annual variation in range of tide, Commonwealth Pier No. 5

6. Annual variation in mean tide level and sea level, Commonwealth Pier No. 5

7. Current stations, approaches to Boston Harbor and Nantasket Roads

8. Current stations, Broad Sound

9. Current stations, President Roads and Main Ship Channel........

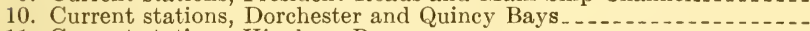

11. Current stations, Hingham Bay

12. Typical current curves for stations $\mathrm{D} 46$, W 13 , and $\mathrm{W} 16$

13. Typical current curves for stations D 47 , W11, W20, and W16...

14. Currents at time of low water at Commonwealth Pier No. 5

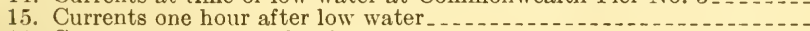

16. Currents two hours after low water

17. Currents three hours after low water

18. Currents four hours after low water

19. Currents five hours after low water

20. Currents at time of high water at Commonwealth Pier No. 5

21. Currents one hour after high water

22. Currents two hours after high water

23. Currents three hours after high water

24. Currents four hours after high water

25. Currents five hours after high water 




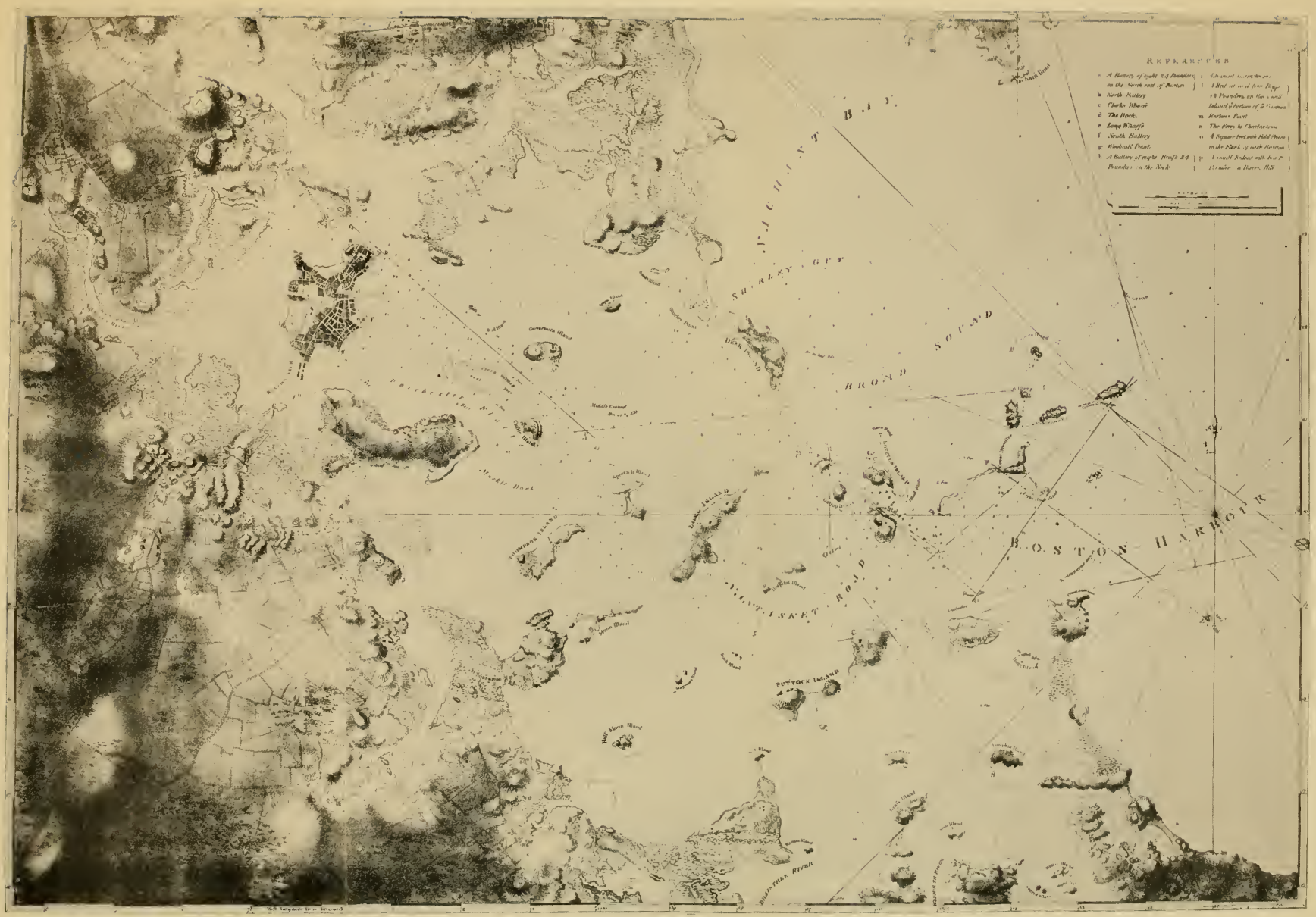






\section{TIDES AND CURRENTS IN BOSTON HARBOR}

\section{INTRODUCTION}

This volume constitutes the fifth of a series on tides and currents in important waterways of the United States, the purpose of which is to make available to the mariner, the engineer, the scientist, and the public generally the tidal and current data now in the files of the United States Coast and Geodetic Survey. In preparing this publication it has been the aim to give in considerable detail the results of all observations in Boston Harbor which were available at the time of the publication.

The tide observations include a long series at the navy yard at Charlestown, which extended more or less continuously from 1847 to 1877; a series at Commonwealth Pier No. 5 in South Boston, which commenced in 1921 and is still being continued; and a number of short series covering periods from a single day to a number of months at various places throughout the harbor. The two longer series are known as primary, a primary tide station being one which is maintained over a series of years for the main purpose of securing extensive tidal information in any locality. The shorter series of observations were generally taken in connection with other hydrographic work, especially for use in the reduction of soundings to a uniform datum. Results from short series are corrected by comparison with simultaneous observations at some primary tide station. In addition to the records of the Coast and Geodetic Survey, there are also included in this volume the results of tidal observations at the navy yard by the Navy officials for the period 1902 to 1911 and shorter series at Moon Head and Nut Island by city officials.

The current observations include those taken under the direction of the following parties: Lieut. C. H. Davis, in 1847 and 1848; Assistant Henry Mitchell, in 1860, 1861, and 1863; and Lieut. R. W. Woodworth, in 1926. Current data secured by the committee on the Charles River Dam in 1902 are also included. In general the current observations at each station covered only a day or two, but at a few stations the observations were continued over longer periods. The observations were reduced by comparison with the tides at one of the primary tide stations.

Through a cooperative arrangement with the Bureau of Lighthouses hourly current observations were taken on the Boston Light Vessel during two periods - from September 22 to December 26, 1913, and from June 8, 1926, to June 30, 1927.

The general characteristics of tides and tidal currents, which were discussed in Special Publication No. 111, are reprinted in the appendix of the present volume for convenience of reference.

Attention is also directed to the tide and current tables which are published in advance annually by the Coast and Geodetic Survey. These tables contain data based upon the latest information available at the time of publication. They include the predicted tides and currents for every day in the year at a number of principal ports and 
also contain summaries of the principal tidal and current elements for several thousand places throughout the world. Other publications of the Coast and Geodetic Survey relating to tides and currents are listed in the back of this volume.

Changes in the physiographic features of Boston Harbor during the past 150 years are illustrated by a comparison of a map published in England in 1775 (fig. 1) with a modern chart of the Coast and Geodetic Survey covering this harbor (fig. 2).

\section{TIDE OBSERVATIONS, BOSTON NAVY YARD}

The first primary tide station in Boston Harbor was established at the Charlestown Navy Yard, June 1, 1847, under the direction of Lieut. C. H. Davis. In the preceding year there was a short series of observations covering the period October 30 to November 20, this short series constituting the earliest tide observations in Boston Harbor of which we have record.

Original tide scale.-At first the observations wore made by reading the height of the water on a tide scale located at the old dry dock. These readings were generally taken every five minutes near the times of high and low water, beginning about a half hour before the estimated time and continuing until after the tide had turned. The tide scale was located on the southern side of entrance to the old dry dock (Dry Dock No. 1), just outside the gate. The scale consisted of copper or bronze strips inlaid in the stone wall of the dry dock, these strips having presumably been set in place during the construction of the dock some 16 years before the tide observations were commenced.

In addition to the scale used for the tide observations, there were five other similar scales in the walls of the dry dock, four of these being inside the dock and the other, like the tide scale, outside the gate. Apparently, the inlaid strips of each scale had been originally spaced at 1 -foot intervals, although during the period of observations and afterwards it was reported that the opening of the seams between the stones of the wall had caused the distance between strips on adjacent stones to be slightly in excess of 1 foot. Each even foot of the scales was marked by a numeral, also inlaid in the stone. The scales inside the dry dock were complete, with the zeros corresponding with the level of the dock sills and the 30 -foot elevation corresponding with the top of the coping, the last inlaid strip being 1 foot below the coping at the 29-foot elevation. The two scales outside the gate, including the tide scale, commenced with the 16 -foot mark and ended with the 29foot mark just 1 foot below the top of the coping.

Auxiliary staff.- It was reported that an auxilary staff was used for the tide observations to obtain the subdivisions of the foot, and such a staff was presumably used also to obtain readings below the 16foot mark of the scale. Just how this auxiliary staff was set is not known. Although it was reported from time to time that the zero of gauge was 30 feet below the top of the coping above the scale, which had been adopted as a bench mark, it is quite reasonable to assume that in the actual setting any one of the footmarks of the auxiliary staff may have been brought opposite the corresponding footmark of the inlaid scale. In such case the distance of the staff zero below the bench mark would have exceeded 30 feet by an amount equal to the excess expansion of the seams between the stones lying above the graduation used in setting the auxiliary staff. 




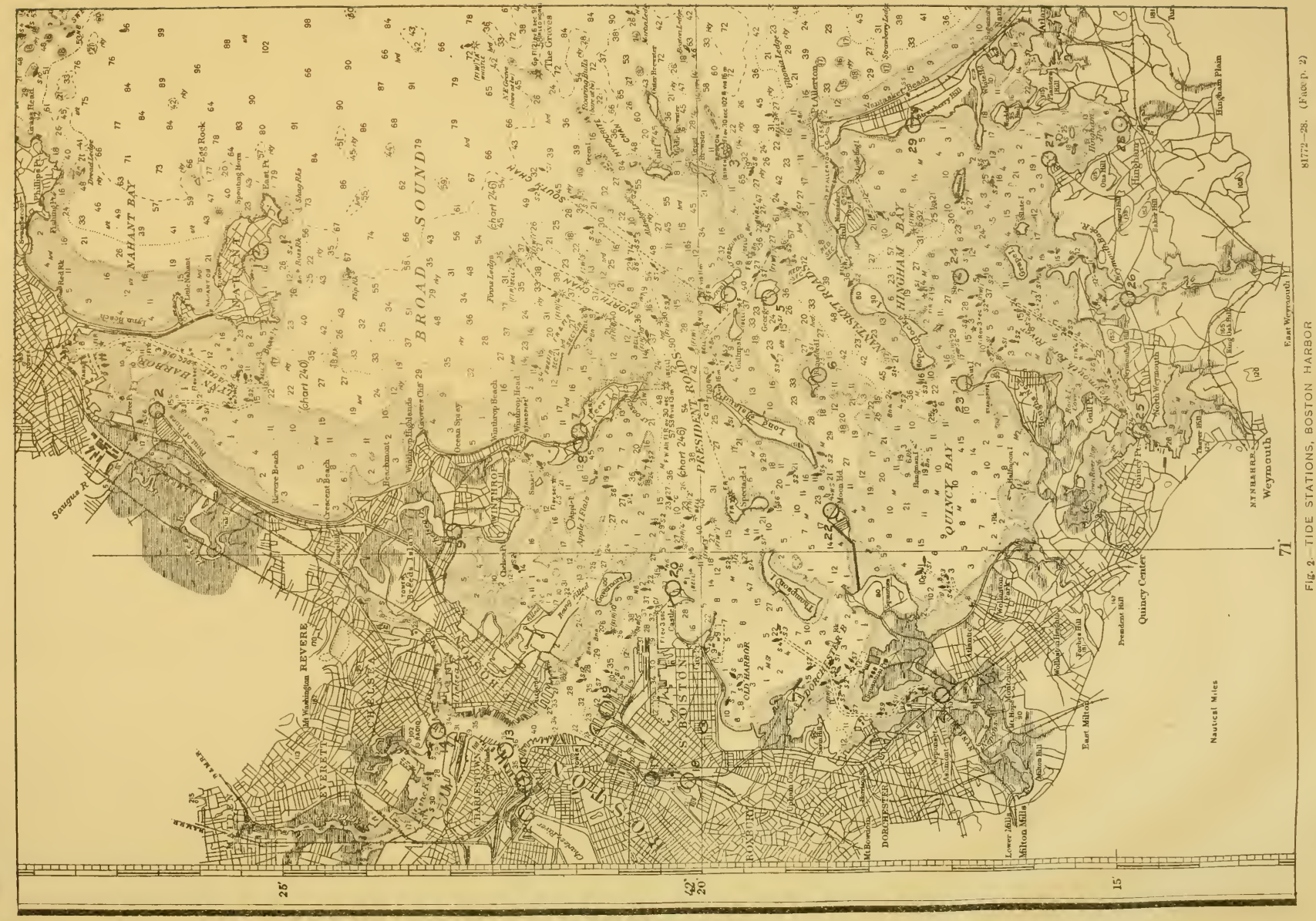



Tide observers.-The first staff readings were taken by Isaac Williams, a sergeant in the Marine Corps, who served as tide observer from the beginning of the series in 1847 until the time of his death on August 14, 1857. He was succeeded by his son-in-law, T. E. Ready, who served until the station was temporarily discontinued in 1866 .

Letter from tide observer. - The following is a copy of a letter written by $\mathrm{Mr}$. Williams in 1857, apparently in reply to inquiries from the office:

Capt. M. L. Sмiтн,

Charlestown, Mass., July 9, 185\%.

Assistant in charge Coast Survey Office, Washington, D. C.

DeAR Sir: Yours of the 7th instant has just been received, and I hasten to answer the question asked therein.

1. "Have the tides been observed at the same spot and the same gauge?" The wall of the dry dock has settled some 4 or 5 inches; there is a difference of 2 inches in some of the feet, say from 20 to 22 feet. The foot will measure near 14 inches, while in some other feet the measure is nearly right. I have within a short time taken the observation a short distance below. I have taken particular notice that it did not vary a moment in time or measurement.

2 . The time is kept by a rather poor watch which I keep regulated by Cambridge time. I have used the same watch, or rather the same time, for a number of years. I have made application to Mr. Mitchell to purchase a good one warranted from 1 to 10 years. Hope you will use your influence in getting the permission to purchase.

3. My work of observing has been always the same.

4. I am not aware that there has been any change in the depth of the water near the gauge or in the channels leading to it. I never look at the difference between mean and apparent time but take my observations every 5 minutes, 30 minutes previous to high and low water. When the last 5 minutes expire I wait until the water begins to rise or fall; I then note (after stopping 5 minutes) the first rise or fall and then in 5 minutes more make another observation and leave until half an hour of the next tide.

Yours truly,

(Signed) IsaAC Wrlliams.

Expansion of seams in dry dock.-From the above letter it appears that in 1857 the seams between the stones had opened by a very noticeable amount, although it is possible that the excess of 2 inches noted by Mr. Williams may have been estimated by eye rather than obtained by direct measurement. Mr. Williams attributed these openings to a settlement of the dock, but from later investigations, especially those of John R. Freeman, chief engineer of the committee on the Charles River Dam, it appears more probable that they resulted from the action of frost in raising the stones above the seams.

Change of location of staff.- Some time in 1857 the place of taking the observations was changed from the entrance to the dry dock to a point about 400 feet easterly, and it is possible that the statement in Mr. Williams's letter that he had "within a short time taken the observation a short distance below," had reference to this change. He adds that he had "taken particular notice that it did not vary a moment in time or measurement." Just how the staff in its new position was set to agree with the old tide scale is not known, possibly by water-level comparisons.

Repairs to dry dock.--It appears that about the year 1859 the dry dock was lengthened by extending the inner end and that other repairs were made. References to these repairs are contained in a 
letter from Henry Mitchell, assistant in the Coast Survey, under date of October 21, 1860, in which he writes-

In a recent letter on tidal matters I gave you information of an error in the position of the Charlestown gauge. I have fully examined this matter now and can make an official report.

Within the last year the blocks of granite, forming the outer position of the dry dock, have been removed to make repairs; and when these were replaced it was thought advisable to drop them a little below their old positions, as it had been found that the coping of the dock inclined inland. The positions of the copper figures were also altered, so as to make the top of the wall read 30 feet, as before.

The gauge is placed in a situation which makes it rather inconvenient for leveling, so that lines run by different persons differ several hundredths.

We have determined, with the utmost care, that the coping directly over copper figures, instead of reading 30 feet on our gauge, reads 29.93 feet-i. e., 0.07 lower than before repairs.

If your mean low water read 14.76 feet below coping before, it should now be 14.69 below same point of new wall.

In my last I stated that the dock coping inclines seaward. I find now that the observer had accidentally reversed his figures and that it still inclines inland over one-tenth foot for the original length of the dock.

This letter contained a rough sketch showing the position of the tide gauge a short distance to the northeastward of the dry-dock entrance.

Mr. Mitchell ascertained that the top of the coping which was being used as a bench mark corresponded to a reading of 29.93 feet on the tide gauge instead of 30 feet. It is assumed that this result was obtained by leveling to the tide staff which was located northeasterly from the dry-dock entrance and did not refer to the bronze scale below the bench mark. The 29-foot division of the bronze scale is on the coping stone itself, and no disturbance of the stone would have affected the relation of bench mark to this scale division. Although Mr. Mitchell assumed that the difference of 0.07 foot between 30 feet and 29.93 feet was due to a change in the elevation of the bench mark, it is not at all certain that the tide staff had previously been set with its zero exactly 30 feet below the bench mark. Taking into consideration the wide openings between the stones, as reported by Mr. Williams in 1857, it seems quite possible that in resetting these stones the bench mark on the coping may have been lowered by even a greater amount than 0.07 foot.

Installation of box gauge.-The tide station appears to have been retained in its position northeast of the dry dock until May 28, 1861, when a box gauge was installed in a tide house a short distance southwesterly from the dry-dock entrance. The following is a copy of Henry Mitchell's descriptions of this gauge:

A cylindrical copper float $51 / 4$ by 9 inches (outside) rises and falls within a copper pipe of 6 inches (inside) diameter, closed at bottom. A wooden box incases the copper pipe and protects the latter. from being jammed by vessels lying alongside the wharf. This box is firmly secured to a pile by iron straps. The water enters the outer box by several half-inch holes near the bottom and enters the copper pipe by six 1/8-inch holes, similarly situated.

The graduated rod, from which the observer reads the height of the tide, passes from a socket in the float upward through the floor of the house built for the self-registering tide gauge. A hole through the roof of the house will allow the gauge rod to pass up to any height. This hole is to be covered whenever it storms, and at such times the observer may shut up the hole, it being provided with hinges. Whenever the observer is not at the station the pole is doubled upon its hinges in order that it need not be exposed to accidents by projecting above the roof-the flying-jib booms of vessels frequently project over the gauge house. 
The reading point upon this new gauge is so placed that the heights will correspond with those upon the staff gauge heretofore used.

The observer may always keep his gauge rod dry and thus prevent changes of float line.

Cost of above, exclusive of expenses for traveling and subsistence of builder, $\$ 42$.

The self-registering gauge to which reference is made in the preceding description was a gauge that had previously been installed by A. Boschke, for the harbor improvement commission of Boston. This gauge was placed in charge of the same tide observer who read the Coast Survey tide gauge.

The box gauge, like the previous staff gauge, was read by the tide observer every five minutes near the times of high and low water.

Observations appear to have been continued with the box gauge until the series was temporarily stopped, September 30, 1866.

Reestablishment of station with self-registering gauge.- On August 15, 1867, the tide station was reestablished and a self-registering gauge was installed at the dock next southwest of the dry dock, A. C. Mitchell having charge of the installation. Mr. Mitchell was instructed to put up a staff for comparative readings and also a box gauge.

The observer first placed in charge of the self-registering gauge when installed in 1867 was C. Levin, who served until September 3, 1867, and was succeeded by Henry Howland, who continued in charge until the end of the series, in 1877.

Establishment of new bench mark. - When the self-registering gauge of the Coast Survey was installed in August, 1867, A. C. Mitchell reported "The old bench mark does not exist, the dry dock having been rebuilt." Mr. Mitchell presumably considered the relaying of the stones as equivalent to the destruction of the old bench mark and established another bench mark near the upper end of the dry dock on a section that was built about the year 1859, the dock being lengthened about that time.

This mark, now designated as "B. M. 2," and originally referred to as the "new bench mark," was described as "the top of the facing of the dry dock on the west side and near the head directly over the foot of the long steps and is designated by an arrowhead cut in the side of the stone." A spike driven into a spile directly in the rear of the tide house and corresponding with the 18 -foot mark on the staff was 1.433 feet below the new bench mark, thus making the new bench mark 19.433 feet above the zero of the tide staff.

In the following year Mr. Mitchell connected the new bench mark with the point on the coping previously used as the old bench mark and ascertained that the new bench mark was 0.176 foot lower than the old one. The zero of the new staff was therefore approximately 19.61 feet below the old bench mark, assuming the elevation of the coping had not been materially changed.

Pressure gauge.--In the latter part of the year 1869 a pressure gauge designed by John M. Batchelder was installed for experimental purposes, the regular gauge being continued in operation. The pressure of the water was transmitted through a rubber bag filled with glycerin, and the rise and fall of the tide was automatically registered in the form of a curve similar to the curve from the regular gauge. In the records it was called the "glycerin gauge." It was retained in use until February, 1872. The records from this gauge are not used in this publication. 
Repairs to dry dock.-In the years 1869 and 1870 extensive repairs were made to the dry dock, which included the relaying of the coping stones. These repairs necessitated the removal of the tide station to another position in July, 1870.

Porcelain tide staff.--In the latter part of the year 1869 the tide staff had been reported to be in bad condition. Under date of October 23, $1869, \mathrm{~A}$. C. Mitchell was informed that a new porcelain staff would be sent to him for installation, and he was instructed as follows:

These tide staffs are made of sheet iron, with a porcelain covering on the face side and paint on the back side. They should be handled with some care to avoid bending, lest the covering be cracked. You should select a place for the one at the navy yard where it will be as secure as may be from accidental injury and remain as a permanent scale for reference, and not too far from the tide gauge. It should be fixed up on the stone wall of a wharf, if it can be done conveniently, and where the height of the water can be read on it at any time. We use for economy ordinary brass wood screws with thick brass washers between the heads of the screws and the plates. These washers fit into the holes in the plates and protect the coating from injury. The plates can be screwed upon a well-painted pine plank, which must be at least 2 inches tbick and a little longer and wider than the plates. The staff is 20 feet long and made in 10 -foot sections, and you will find in putting it up that the lower end of the upper section must go a little over or under the upper end of the other piece in order to preserve the proper distance between the divisions. The pine plank that receives the plates may be fixed directly upon the wall if that is perpendicular, but if not, then to another piece of timber properly cut to bring it so, and painted. All the bolts or spikes used should be of brass or copper in order to secure durability.

If you can do so, it will be best to place the 20 -foot mark of this staff on a level with the old bench mark at the entrance of the dry dock, which reads 30 feet on its own scale. We believe some of the copper figures and marks are still remaining which will enable you to find that place for the 30 . That bench mark has been used a great deal and we know its history, and if you can place the new staff as here directed it will be very convenient in computations, there being just 10 feet difference. We believe the old bench mark has never been submerged more than once or twice when there were very severe easterly storms.

We suppose you will have to use a level to fix the position of the new staff or to ascertain its height relatively to the bench marks, and while doing so we want you to level between the old bench mark at the entrance to the dry dock and the bench mark fixed by you in August, 1867, near the head of the dry dock.

In reply to the above Mr. Mitchell wrote under date of November 1,1869 , asking for further instructions and stated-

The old bench mark is again gone, as they have just taken down the lower end of the dry dock.

In reply to this letter the assistant in charge of the Coast Survey office wrote-

We infer from your letter of the 1st that the repairs that are being made at the dry dock are so extensive that it is not best for us to put up the porcelain staff until they are completed. When they renew the copper scale at the entrance of the dry dock we shall want to know how it compares with the old one, and it will, we suppose, be necessary for us to do it by leveling. We will therefore defer the whole thing till then.

\section{On January 12, 1870, A. C. Mitchell wrote-}

Before leaving Boston I found that the marks on the tide staff at the navy yard had become so obliterated that it could not be read at low water. So I ordered John Cass to prepare the pile for the porcelain plates (the same pile being the only suitable place) and instructed him how to put the plates on so that the 18-foot mark would come in the same place as before. I expect that this has been done and also that the dry dock is done. The plates can be moved at any time, so that the 20 -foot mark can be on a level with the bench mark, but the sooner it is done the better, before the screws get rusted in. Would it not be best for me to go and attend to that when I get through here? 
On February 9, 1870, Mr. Mitchell again wrote-

I have altered the staff at the Charlestown Navy Yard as you clirected, so that the 20-foot mark on the staff corresponds with the bench mark at entrance of dry dock. The bench mark at foot of entrance of dry dock is 0.155 foot above the bench mark at head of dry dock. These levels I ran over eight times on three separate days (the only suitable weather I have had), and they all agree with one another within half a hundredth-most of them nearer-so that I am quite sure they are correct. The staff is attached to the same pile as before, behind the tide house, 8 or 10 feet from it.

Change in location of gauge.-On July 19-21, 1870, the self-registering tide gauge was moved to the next pier on the opposite side of the same slip on which it had been established. The removal of the tide staff was delayed to aw ait the arrival of a leveling instrument, but the staff was carried away by a colliding steamer on July 24 and reinstalled July 26, 1870 , with the 20 -foot mark level with bench mark No. 1. Apparently there was no further change in the position of the tide station until it was discontinued on February 19, 1877.

Later series at navy yard.- Since the primary station was discontinued in 1877 observations covering a few tides were made at the navy yard in 1892, 1893, and 1894. These were taken in connection with hydrographic work, but the series were too short to be of any value except for comparison.

In 1902 an automatic tide gauge was installed by the public works department of the navy yard, and observations have been continued to the present time. The records, however, have not been completely tabulated, but such results as are arailable are included in this publication.

The datum to which these later observations are referred has been reported as 14.54 feet below bench mark 2. If the eleration of bench mark 1 above bench mark 2 is taken as 0.36 foot from the average of all the levels between 1900 and 1923 , this datum is found to be 14.90 feet below bench mark 1 .

Reduction to a uniform datum.-The reduction of all the observations at the navy yard to a uniform datum must depend largely upon a single bench mark, the top of the coping of the dry dock over the inlaid tide scale used for the early observations. Unfortunately, this bench mark has been subject to some changes, as already noted, the principal changes being the expansion of the joints between the stones of the dry-dock wall by the action of frost and the changes due to relaying the stones at times of repairs. The exact amount of these changes as they occurred at different times can not now be determined, but we can draw some conclusion in regard to the probably maximum variations from such information as we have available.

Dry Dock No. 1, at Charlestown.-Together with one being built at Norfolk, Va., at the same time, Dry Dock No. 1, at Charlestown, is the oldest dry dock in the United States. It was authorized by act of Congress passed March 3, 1827, and the coping was completed in 1831. It was built under the direction of Loammi Baldwin, a noted engineer of that period. In preparing for the foundation, excavations were made through 18 inches of marsh mud, 5 feet of blue clay, 13 feet of yellow sand and gravel, then hard clay interspersed with small strata of sand, gravel, and bowlders. Piles were driven 3 feet from centers each way to hardpan or rock at depths of from 8 to 30 feet. The walls are of eastern granite, laid in cement mortar. 
Tide observations were commenced in 1847 , about 16 years after the completion of the dock. Ten years later, in 1857, the tide observer reported opening of joints between the stones under the bench mark, estimated to be as much as 2 inches in some cases. About two years later, in 1859-60, repairs were made which involved the relaying of the coping stones. Other repairs involving the relaying of the coping stones were made 10 years later, in 1869-70.

Leveling connections.- Until the year 1867 the tide staffs were referred solely to bench mark 1, the top of the coping at the entrance to the dry dock. In 1867 bench mark 2 was established on the coping near the head of the dry dock.

The elevation of the old bench mark No. 1 above the new bench mark No. 2 has been reported from time to time as follows:

June, 1868, A. C. Mitchell, Coast Survey _. _ _ _ _ _ _ _ _ _ _ . 0.176

Feb. 8, 1870, A. C. Mitchell, Coast Survey

July 26, 1870, A. C. Mitchell, Coast Survey _... 153

1878, city survey office, Boston, Mass

1882, Gilbert Hodges

January, 1900, Hyde \& Sherry, civil engineers, Boston........... . 35

1903, F. M. Miner, city surveyor's office, Boston

1903, W. E. Spear, Charles River Dam, Boston ... . . . 34

1903, H. B. Wood, State harbor commission

Aug. 9, 1916, N. H. Heck, Coast and Geodetic Survey

Oct. 13-16, 1923, E. B. Roberts, Coast and Geodetic Survey

Nov. 15, 1927, Dwight P. Robinson \& Co. (Inc.), New York._..... . 36

The change from 0.176 in 1868 to 0.155 in 1870 was probably due to the repairs in 1869 , while the gradual change from 1870 to 1900 may be assumed to be due primarily to the action of frost on the seams between the stones. Between 1900 and 1927 the changes are small and irregular.

In 1916 the third bench mark, designated as bench mark 3, which consisted of a standard disk of the Coast and Geodetic Survey, was established on Dry Dock No. 2 at the navy yard. This dock was built in 1905. The relation of bench mark 3 to the two older benches bas been determined by levels as follows:

Aug. 9, 1916, N. H. Heck, Coast and Geodetic Survey.-

October, 1923, E. B. Roberts, Coast and Geodetic Survey.-

November, 1927, Dwight P. Robinson Co. (Inc.), New York

\begin{tabular}{|c|c|c|}
\hline & $\begin{array}{l}\text { Below } \\
\text { B. M. } 1\end{array}$ & $\begin{array}{l}\text { Below } \\
\text { B. M. } 2\end{array}$ \\
\hline & $\begin{array}{l}\text { Foot } \\
0.89\end{array}$ & $F_{0 o o t}{ }_{0.52}$ \\
\hline York & & \\
\hline
\end{tabular}

Assuming that bench mark 3 has remained fixed, the above results suggest that both the older bench marks may have settled from 0.03 to 0.04 foot between 1916 and 1927, although the differences are too small to be conclusive.

Tide scale.- In 1903 measurements under the direction of John R. Freeman, chief engineer of the committee on the Charles River Dam, were made between the footmarks of the inlaid tide scales on the walls of the dry dock. It was found that the spacing between marks on the same stone was always exactly 1 foot, but between marks on different stones the difference was a little in excess of 1 foot. On the tide scale, directly under bench mark 1 , the excess varied from 0.04 to 0.07 foot, with a total excess of 0.36 foot between the top of the coping and the 
16-foot mark, which was the lowest division of the scale. It was also determined that the top of the coping was 30.47 feet above the average level of the gate sills of the dry dock.

Another measurement of this scale, made under the direction of an officer of the Coast and Geodetic Survey on June 27, 1927, indicated an excess varying from 0.04 to 0.08 foot between individual stones and a total excess in the entire scale which was 0.04 foot greater than that obtained in 1903. Although this suggests that bench mark 1 may have risen 0.04 foot during the period 1903 to 1927 , it will be noted that the levels between bench mark 1 and bench mark 2 show a relative change of only 0.02 foot for this period, and that levels to bench mark 3 indicate a settlement of 0.04 foot between 1916 and 1927 .

Conclusions in regard to bench-mark changes.-What conclusions can be drawn from the above data in regard to any changes in the elevation of bench mark 1 since the tide observations were commenced in 1847? Changes from three causes are conceivable-settlement of the dock as a whole, raising of the stones by the action of frost in the seams between the stones, and changes caused by relaying the stones during repairs.

The dock was substantially constructed by a capable engineer; approximately 16 years had elapsed after its construction before the tide observations were commenced; and a careful investigation by the chief engineer of the committee of the Charles River Dam in 1902 failed to reveal any evidence of a settlement. For these reasons we may safely disregard the question of settlement.

Changes due to other causes are in evidence, but the exact amount of such changes is unknown. It will be noted that in 1857 an expansion of the seams between stones amounting to approximately 2 inches in some cases was reported. In 1903 a careful measurement gave the maximum expansion between two stones as 0.07 foot, or a little less than 1 inch, and in 1927 this expansion was found approximately the same. Taking into account the possibility that the value given in 1857 may have been only a rough estimate rather than a direct measurement, there appears to be no reason for concluding that the elevation of the bench mark on the coping since 1903 has differed materially from its elevation in 1857 because of the opening of the seams between the stones. It appears probable that the expansion due to the action of the frost had already reached a maximum in 1857 , and it is not impossible that this expansion had reached a maximum prior to that time. As the dry-dock walls had been completed approximately 16 years before the tide observations were commenced in 1847 , it is reasonable to assume that there had already been some expansion in the seams prior to the beginning of the observations, and the bench mark may not have changed much in elevation between that time and 1857 .

During the repairs of 1859 some of the stones were relaid, and it is probable that the bench mark on the coping was lowered a little but through the action of frost in subsequent years again raised. Similarly in 1869-70 the bench mark may have been lowered again a small amount by repairs and later raised through the action of frost.

From the year 1900 to the present time (1927) leveling connections with other bench marks indicate that bench mark 1 has remained very nearly fixed. If all the leveling is accepted as absolutely accurate, bench mark 1 apparently rose 0.02 foot relative to bench 
mark 2 between the years 1900 and 1916 and then settled 0.01 foot relative to bench mark 2 or 0.04 foot relative to bench mark 3 between the years 1916 and 1927 , but these differences are too small to be conclusive.

Because of the uncertainty in regard to the exact amount of the fluctuation in the elevation of bench mark 1 due to the causes described and also for want of positive information concerning the methods always used for connecting the several tide staffs with the bench mark, no attempt has been made to apply corrections for these fluctuations, but the heights of the tide planes as directly obtained are compiled in the tables which follow. The general uniformity of the results indicate no considerable change in the datum.

Reduction of records.-Detailed results from each year of observations obtained from the reduction of the tide records for the navy yard are given in Tables 1 to 8 , and summaries of the tidal data are included in Tables 25 to 28 . The items contained in these tables are explained in the following paragraphs:

Lunitidal intervals. - The mean high-water lunitidal interval is the average time that elapses between the transit of the moon over the meridian of a place and the following high water. Similarly, the mean low-water lunitidal interval is the time between the transit of the moon and the following low water. For brevity these intervals are frequently designated simply as the high and low water intervals and are represented by the symbols HWI and LWI, respectively. In general the tides are referred to either the upper or lower meridian passage of the moon. The intervals usually vary from day to day with changes in the phase, parallax, and declination of the moon and sun, but the average over a considerable period of time is fairly constant for any particular locality.

The mean high-water interval is also sometimes called the "corrected establishment of the port," and is approximately the same as the "high water, full and change," which applies to the tide at the times of new and full moon. At such times, however, the intervals are usually 10 to 15 minutes greater than the mean.

The mean high-water interval at the navy yard, as derived from 30 years of observations from 1847 to 1876 , is 11.44 hours, or 11 hours 26 minutes, and the mean low-water interval for the same period is 5.23 hours, or 5 hours 14 minutes. The intervals as obtained for the individual years will be found in Table 1. The averages for the three 10-year groups are also given.

Mean rise interval.-The mean rise interval, abbreviated MRI, is the average time between the transit of the moon and the middle of the period of the rise of the tide. It may be computed by adding the half period of rise to the mean low-water interval, rejecting multiples of the semidiumal tidal period ( 12.42 hours) when desired. The mean rise interval is convenient for comparing the time of the tides at different stations when it is unnecessary to distinguish between the high and low water differences. The mean rise interval for the navy yard is 8.34 hours.

Tropic lunitidal interials.-Near the times of the maximum declination of the moon there is often considerable inequality both in the intervals and in the heights of the two high waters and also of the two low waters of each day. The term "tropic tides" is applied to 
the tides at this time. From an harmonic analysis of the observations for the year 1869, the following tropic intervals were obtained for the navy yard: Tropic higher high-water interval- that is, the interval referring to the higher of the two high waters of the day at the time of the tropic tides-11.36a hours; tropic lower high-water interval, referring to the lower of the two high waters of the day, $11.58 \mathrm{~b}$ hours; tropic higher low-water interval, referring to the higher of the two low waters of the day, 5.15 a hours; and tropic lower low-water interval, referring to the lower of the two low waters of the day, $5.46 \mathrm{~b}$ hours. The intervals marked "a" refer exclusively to the moon's upper meridian passage at the time of its north declination and to the lower meridian passage at the south declination; the intervals marked "b" refer exclusively to the moon's lower meridian passage at its north declination and to the upper meridian passage at the south declination.

From an inspection of these tropic intervals, the sequence of the tides is higher high water to lower low water followed by the lower high and higher low water.

Greenwich intervals. - The lunitidal intervals which are usually computed and published refer to the transits of the moon over the local meridian of the place where the tides have been observed. Such intervals do not afford a direct means for comparing the time of the tide at stations located in different longitudes but require certain corrections for the difference in longitude. If the lunitidal intervals for all stations were referred to the transits of the moon over some standard meridian, such as the meridian of Greenwich, they would afford a direct means of obtaining the actual difference in the time of tide without further correction. In west longitude the Greenwich intervals exceed the local intervals by an amount equal to the average time elapsed between the transit of the moon over the meridian of Greenwich and the transit over the local meridian. For the longitude of the navy yard, and also for Commonwealth Pier No. 5 in Boston, this is 4.90 hours. Applying this difference to the local lunitidal intervals and rejecting multiples of the semidiurnal period when desired, the corresponding Greenwich intervals are obtained. The Greenwich intervals for mean high water, mean low water, and mean rise of tide are included in Table 25.

Duration of rise of tide. - The mean duration of rise of tide, abbreviated $\mathrm{DR}$, is the average time required for the water to rise from its minimum height at low water to its maximum height at high water. Similarly the mean duration of fall is the average time required for the tide to fall from high to low water. Since the average period between two consecutive high waters or between two consecutive low waters is the semilunar day, or 12.42 hours, the sum of the mean duration of rise and the mean duration of fall must equal this amount. The mean duration of rise for the navy yard from 30 years of observations is 6.21 hours, and the mean duration of fall is the same. Therefore, the average time required for the tide to rise from low to high water at the navy yard is the same as the average time required for it to fall from high to low water. The duration of rise for individual years will be found in Table 1. The average for three 10-year groups are also given.

High and low water heights.-The mean high and low water heights at the navy yard for each of the 30 years of observations by the Coast 
Survey and also for 9 years of observations by the navy-yard authorities are given in Table 2. These heights are referred as near as practicable to the zero of the original tide scale, which was 30 feet below bench mark 1 on the coping of the dry dock. In Table 3 these heights are referred to the sea-level datum which is defined on page 41. The mean high water from the entire series is 4.81 feet above the sea-level datum and mean low water 4.93 feet below this datum. When corrected for the longitude of the moon's node these values become 4.80 feet and 4.91 feet, respectively.

The spring and neap high and low waters depending upon the phase of the moon, the perigean and apogean high and low waters depending upon the parallax of the moon, the tropic high and low waters depending upon the declination of the moon, the diurnal high and low waters depending upon the daily height inequalities, and the extreme high and low waters depending upon a combination of astronomical and meteorological conditions are included in Table 27. These planes were derived from the corresponding tidal ranges and inequalities.

Mean range of tide.- The mean range of tide is the difference in height between the mean of all high waters and the mean of all low waters. From theoretical considerations, the range of tide is least when the longitude of the moon's node is zero and the inclination of the moon's orbit to the Equator is at a maximum and greatest when the longitude of the moon's node is $180^{\circ}$ and the inclination of its orbit to the Equator a minimum. This inequality has a period of approximately 19 years, and in order to reduce the range as determined from a single year of observations to a mean value a correction factor is necessary. The mean of the corrected ranges for the navy yard for 39 years is 9.71 feet. The mean range for each individual year as directly obtained and also as corrected for the longitude of the moon's node will be found in Table 4. The corrected ranges have also been arranged in groups, the first three groups containing 10 years each and the last group 9 years. The averages for these are (1847-1856) 9.83 feet, $(1857-1866) 9.77$ feet, (1867-1876) 9.66 feet, and (1902-1911) 9.57 feet. It will be noted that the range consistently diminishes but not by a uniform amount, the difference between the third and last group being only 0.09 foot, although there is a gap of 25 years between these two groups. Changes in the mean range of tide in harbors due to various changes in the configuration of the shore line and bottom are not unusual.

Ranges depending upon phase and parallax of the moon.-The spring range of tide is the average maximum semidiurnal range near the times of new and full moon; the neap range of tide is the average minimum semidiurnal range near the times of the quadratures of the moon; the perigean range of tide is the average maximum semidiurnal range when the moon is near its perigee; and the apogean range is the average of the minimum semidiurnal range when the moon is near its apogee.

Near the times of new and full moon the forces of the sun and moon conspire to increase the range of tide, and near the quadratures their forces are opposed to each other, causing a diminution in the range. The nearness of the moon when it is in perigee tends to give an increased range, while its greater distance when in apogee tends to diminish the range. The spring and neap ranges of tide at the navy yard, as derived from a phase reduction of the 
high and low waters for 30 years (1847-1876), are 11.09 and 8.32 feet, respectively. The perigean and apogean ranges, as derived by applying to the mean range differences obtained from the harmonic analysis of the hourly heights for the year 1869, are 11.37 and 8.39 feet, respectively.

It will be noted that the perigean range is a little greater than the spring range. In this locality the parallax of the moon appears to have a little greater influence in increasing the range of tide than does the phase of the moon. When the perigean and spring tides occur about the same time of month the range of tide will be especially large, and when the apogean and neap tides occur together the range will be especially small.

Diurnal ranges.-There is usually a difference in the height of the two high waters of each day and also in the height of the two low waters. For distinction, the two high waters of each day are designated as the higher high and lower high and the two low waters as the higher low and the lower low. The great diurnal range of tide is the difference in height between the average of all the higher high waters and the average of all the lower low waters. The small diurnal range is the difference in height between the average of all the lower high waters and the average of all the higher low waters.

The diurnal ranges for the navy yard, obtained by applying inequalities from the reductions of a single year (1869) to the mean range for 39 years, are 10.44 feet for the great diurnal range and 8.98 feet for the small diurnal range.

Tropic ranges.- The high and low waters near the times of maximum declination of the moon are designated as tropic tides. At these times, while the average semidiurnal range of tide is less than usual, the inequality in the heights is generally greater. The great tropic range is the difference in height between the tropic higher high water and the tropic lower low water, and the small tropic range is the difference in height between the tropic lower high water and the tropic higher low water. The values of these ranges, as derived from an analysis of the observations for the year 1869, are 10.24 feet for the great tropic range and 7.85 feet for the small tropic range.

Extreme ranges.-Extreme tides result primarily from meteorological conditions, but they may also depend largely upon combinations of astronomical causes. The highest and lowest tides for each month of observations at the navy yard, as far as available, are given in Tables 5 and 6 . The average of the monthly extremes for each year and the averages for the corresponding calendar months throughout the series are also given. The average monthly extreme range of tide is the difference between the average of the monthly extreme high waters and the average of the monthly extreme low waters. For the navy yard this was found to be 13.93 feet. The greatest range between the highest tide observed and the lowest tide observed was 18.5 feet.

Diurnal inequalities.-The diurnal high-water inequality is the difference between the mean of the higher high waters and the mean of all high waters. The diurnal low-water inequality is the difference between the mean of all low waters and the mean of the lower low waters. As determined from the high and low waters for one year (1869), the diurnal high-water inequality at the navy yard was found to be 0.40 foot and the diurnal low-water inequality as 0.33 foot.

$$
81772-28-2
$$


Mean tide level.-Mean tide level, also known as half tide level, is a plane midway between the mean of all high waters and the mean of all low waters. In the reduction of the long series of observations at the navy yard the mean tide level was obtained for each year of observations, and the results are given in Table 7 . The mean tide level for the entire series of 39 years was found to be 20.12 feet above the zero of the tide scale. In Table 8 the mean tide level for each year is referred to the sea-level datum.

Spring and neap tide level.--Aside from the irregular fluctuations due primarily to meteorological conditions, there appear to be small variations in the mean tide level due to change in the phase of the moon. From the phase reductions for the navy yard covering a period of 30 years, from 1847 to 1876 , the spring tide level, or average level at the time of the spring tides, was found to be 0.04 foot below the mean tide level, and the neap tide level, or average level at the time of the neap tides, was 0.04 foot above the mean tide level.

Mean sea level.-The mean sea level is obtained by taking the average of the hourly heights of the tide over a considerable period of time. For places near the coast mean sea level thus obtained differs very little from the mean tide level derived from the high and low waters. The records for three years-1868, 1869, and 1871-at the navy yard were reduced to obtain mean sea level, and the average elevation of mean sea level above mean tide level for these years was 0.16 foot. Adding this difference to the mean tide level as obtained from the 39 years of observations, we have 20.28 feet as the elevation of mean sea level above zero of the original tide scale. A discussion of the sea-level datum will be found on page 41 under "Tidal datums."

Harmonic constants. - Tidal harmonic constants from an harmonic analysis of the hourly heights of the tide at the navy yard have been determined from a series of 369 days, beginning January 1, 1869. The processes used in the analysis are described in Special Publication No. 98 of the Coast and Geodetic Survey. The harmonic constants from this series of observations are given in Table 28. For many years, until the more recent series of observations was started in South Boston, these constants were used in making the tidal predictions for Boston for the annual tide tables of the Coast and Geodetic Survey.

Ages of the tide.-Inequalities in the tide resulting from changes in astronomical conditions will generally follow the assumed cause by several hours in time. The time that elapses between the cause and the maximum effect on the tide is called the age.

The following ages have been derived from the harmonic constants for the navy yard: The phase age, or interval by which the spring and neap tides follow the new and full moon or the quadratures, 38 hours; the parallax age, or interval by which the perigean and apogean tides follow the corresponding positions of the moon, 57.7 hours; and the diurnal age, or interval by which the tropic tides follow the maximum north and south declination of the moon, 19.1 hours.

\section{TIDE OBSERVATIONS, COMMONWEALTH PIER NO. 5}

A primary tide station was established on Commonwealth Pier No. 5, South Boston, on May 3, 1921. The float well is a 12-inch iron pipe with a conical casting containing a $3 / 4$-inch hole at the bottom for the access of water. The pipe is about 23 feet long to the intake, and 
below the intake there is a supporting section $71 / 2$ feet lons in which are cut four 3 by 9 inch slots for the admission of water. The intake to the main pipe is about 7 feet below mean low water and 6 feet above the bottom of the harbor. Kerosene is used inside the float pipe to prevent freezing in the wintertime. Any difference in level in the pipe due to the introduction of this kerosene is taken into account in the tabulations by comparative readings on an exposed tide staff.

Tide staff.-A portable tide staff was installed, the support being secured to a pile on the north side of the pier near the inner end. At first a 12-foot standard staff was used with the 12-foot mark corresponding to the top of support. On September 1, 1922, this was replaced by a new staff, the support for which was nailed to the old support with the top at the same elevation. The new portable staff was set with the 15 -foot mark corresponding to the top of this support. All tabulations of this series have been referred to the sccond staff. From first-order levels, October 13 to 16,1923, by party of E. B. Roberts, the zero of this staff was found to be 17.97 feet below the old bench mark 1 at the navy yard. As the original series of observations at the navy yard was referred to a datum 30 feet below this bench mark, the staff readings of the later series can be made comparable with the old series by the addition of the constant 12.03 feet.

Primary bench mark.-As the tide-staff support in its exposed position is in more or less danger of destruction or change, it is necessary to check its elevation from time to time by leveling to some bench mark in the near vicinity. The mark adopted as the primary bench mark for this series of observations is designated as "B. M. 7 " and consists of a standard disk stamped "7/1922," which is cemented into the upper surface of water table on the side of heating plant opposite Commonwealth Pier No. 5. This bench mark is 21.45 feet above the zero of the tide staff installed in September, 1922. The primary bench mark has also been connected by levels with a number of other bench marks in Boston to further insure the permanency of the tidal datums.

Reduction of records.-The records of the observations at Commonwealth Pier No. 5 have been reduced by the usual methods. Monthly means and extremes of the high and low waters are compiled in Tables 9 to 24, and summaries of the tidal data are included in Tables 25 to 28. Definitions of the various tidal constants have already been given on pages 10-14 in connection with the observations at the navy yard.

Monthly means.-The monthly means for the first portion of the series of observations at Commonwealth Pier No. 5 to the end of the year 1924 were derived from 29-day groups, beginning with the first of each calendar month. Beginning with the year 1925, the means have been derived from the full calendar months. The record from the first few months of observations was rejected as defective on account of the clogging of the intake to the float well, and the tabulated means begin with August, 1921.

Annual variation.-The several tide planes appear to be subject to certain seasonal fluctuations, as illustrated in Figures 3 to 6, which represent the means from the observations at Commonwealth Pier No. 5 covering a period of a little more than five years. By Figure 3 it will be noted that the high water in the summer months is several tenths of a foot higher than in the winter months. Figure 4, which represents the annual variation in the low water, is somewhat similar to that for the high water but shows a secondary depression through the middle 


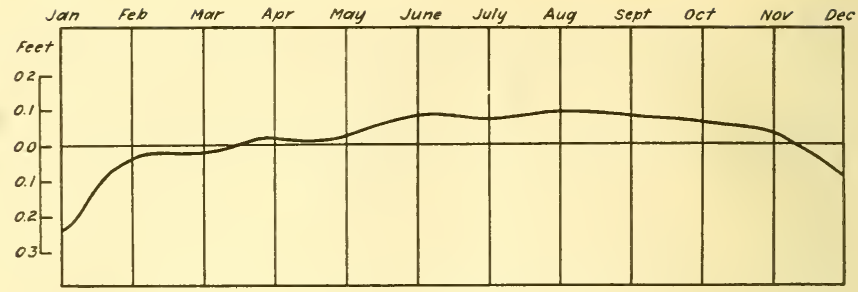

FIg. 3.-ANNUAL VARIATION IN HIGH WATER, COMMONWEALTH PIER NO. 5

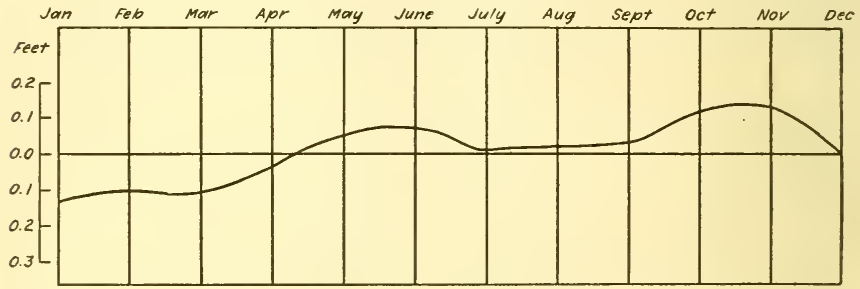

Fig. 4.-ANNUAL VARIATION IN LOW WATER, COMMONWEALTH PIER NO. 5

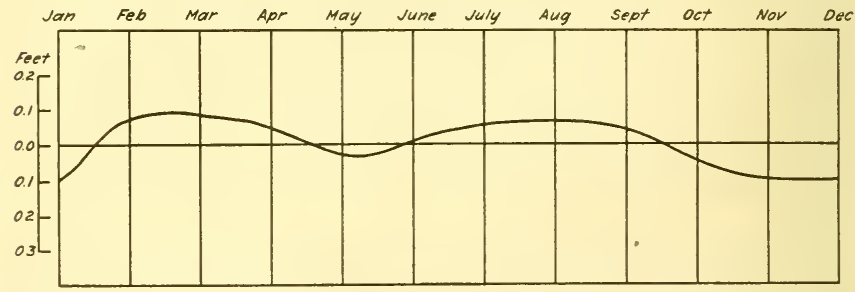

Fig. 5.-ANNUAL VARIATION IN RANGE OF TIDE, COMMONWEALTH PIER NO. 5

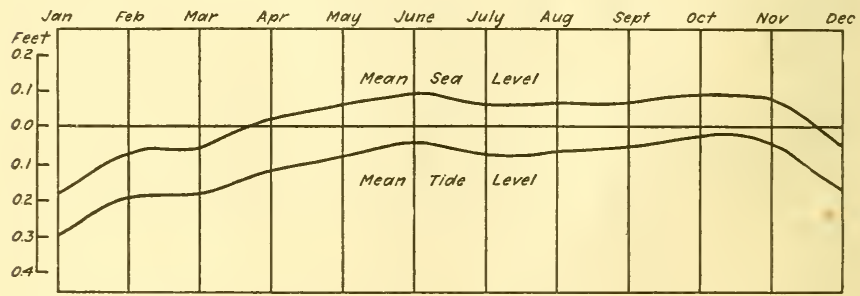

FIg. 6.-ANNUAL VARIATION IN MEAN TIDE LEVEL AND MEAN SEA LEVEL. COMMONWEALTH PIER NO. 5 
of the summer. Figure 5 shows the variation in the mean range, which depends upon the relative variation in the high and low water heights. This curve shows two maxima and two minima points.

Mean tide level, which is a mean between the high and low water heights, and the sea level, which is the average of the hourly heights, are represented in Figure 6 . It will be noted that these two curves are approximately parallel and that the mean tide level is consistently about a tenth of a foot lower than the sea level. Both the mean tide level and the sea level are from two to three tenths of a foot higher in the summer months than in the winter months.

The fluctuations illustrated by these figures may be due partly to meterological conditions depending upon changes in the seasons and partly to astronomical conditions depending upon changes in the declination and parallax of the sun.

Intervals, ranges and inequalivies.-In addition to the principal tidal elements derived from the full series of observations, the summaries of Tables 25 to 28 include the following quantities for Commonwealth Pier No. 5. Intervals, ranges, and tide planes depending upon the tropic tides, and the ages of the tide were computed from the harmonic constants given in Table 28. The spring, neap, perigean and apogean ranges were obtained by applying differences derived from the harmonic constants to the mean range of tide from the full series of observations. The diurnal high and low water inequalities were obtained from three complete years of observations, 1922 to 1924 , inclusive. The diurnal ranges were obtained by applying the diurnal inequalities to the mean range for the entire series of observations. The relations of the spring and neap tide levels to the mean tide level were obtained from a phase reduction of the high and low waters for the year 1924.

Tide planes.-The tide planes given in Table 27 are referred to both the sea-level datum and the Boston low-water datum which are defined on page 41 . The relations of the different tide planes to each other and to mean tide level depend largely upon the various tidal ranges and inequalities. The mean tide level at the navy yard was derived independently from the high and low water observations covering some 39 years. The observations at Commonwealth Pier No. 5 available at the time of this publication cover a period of only a little more than five years. Because of the fluctuations in the yearly mean level in any locality, this shorter period of observations is not sufficient for a satisfactory independent determination of mean tide level. Comparisons have therefore been made with simultaneous observations at Portland, Me., where a mean level has been determined from 15 years of observations. During the period of observations at Commonwealth Pier No. 5 it appears that the average level of the water was 0.07 foot below normal, and this difference has been applied in Table 27 to the mean tide level and other tide planes determined from the observations at Commonwealth Pier No. 5, excepting the highest and lowest tides observed, which are taken without modification.

Harmonic constants.- The harmonic constants for Commonwealth Pier No. 5, which are given in Table 28, were derived from an analysis of two 369-day series beginning January 1, 1922, and January 1, 1924. These constants are now being used in making the tidal predictions for Boston, published in the annual tide tables of the Coast and Geodetic Survey. 


\section{TIDE OBSERVATIONS, MISCELLANEOUS SERIES}

Besides the principal series of tide observations at the navy yard and at Commonwealth Pier No. 5, there have been a number of shorter series in various parts of the harbor which were obtained from time to time in connection with other hydrographic work. The observations have been reduced and compared with simultaneous observations at certain standard ports, and the results are given in Table 29. For the comparisons the observations at the navy yard and Commonwealth Pier No. 5 were used as far as practicable, but when observations at either of these stations were not available other ports of reference were used.

The results obtained from very short series of observations may be affected by accidental conditions prevailing at the time of the observations, which would be largely eliminated in a longer series. For this reason such results are to be considered only as approximate values and subject to adjustments based upon other tidal data for the same general locality.

Adjusted tidal data.-Table 30 contains adjusted tidal results for the tide stations which are enumerated in the preceding table. In obtaining these adjusted values consideration was given to various factors involved. The results from the more recent observations were given preference to those of earlier observations, not only because of possible changes in the tide due to changes in the configuration of the harbor but also because the later series were presumably made under more favorable conditions. The difficulties of maintaining accurate time in the earlier years were undoubtedly much greater than during more recent years.

In making the adjustment consideration was given to the harbor as a whole. The times of the high and low waters throughout the harbor differ by only a small amount, the tides at the navy yard occurring about a quarter of an hour later than at Boston Light. The mean range of tide at the navy yard is about 0.7 foot greater than at Boston Light. The mean range throughout the harbor varies from 9 to 10 feet.

The spring and neap ranges are included in this table. For the two primary stations at the navy yard and Commonwealth Pier No. 5 these ranges were obtained directly from the observations. For the other stations they were derived by applying to the mean range factors based upon the observations at the primary stations.

Information in regard to the distance that tidal influences extend up the several rivers is included in Table 30 for convenience of reference.

\section{CURRENT OBSERVATIONS, 1847 AND 1848}

In connection with a hydrographic survey of Boston Harbor under the direction of Lieut. Commander Charles H. Davis, current observations were taken between June 9 and October 22, in 1847, and between June 7 and October 21, in 1848. A sailing schooner, the U. S. S. Gallatin, was used in making the observations, and the work was under the immediate supervision of Lieut. John N. Maffitt. Although the apparatus used is not described in the records, it is presumed that the velocities were obtained by a log line and that 



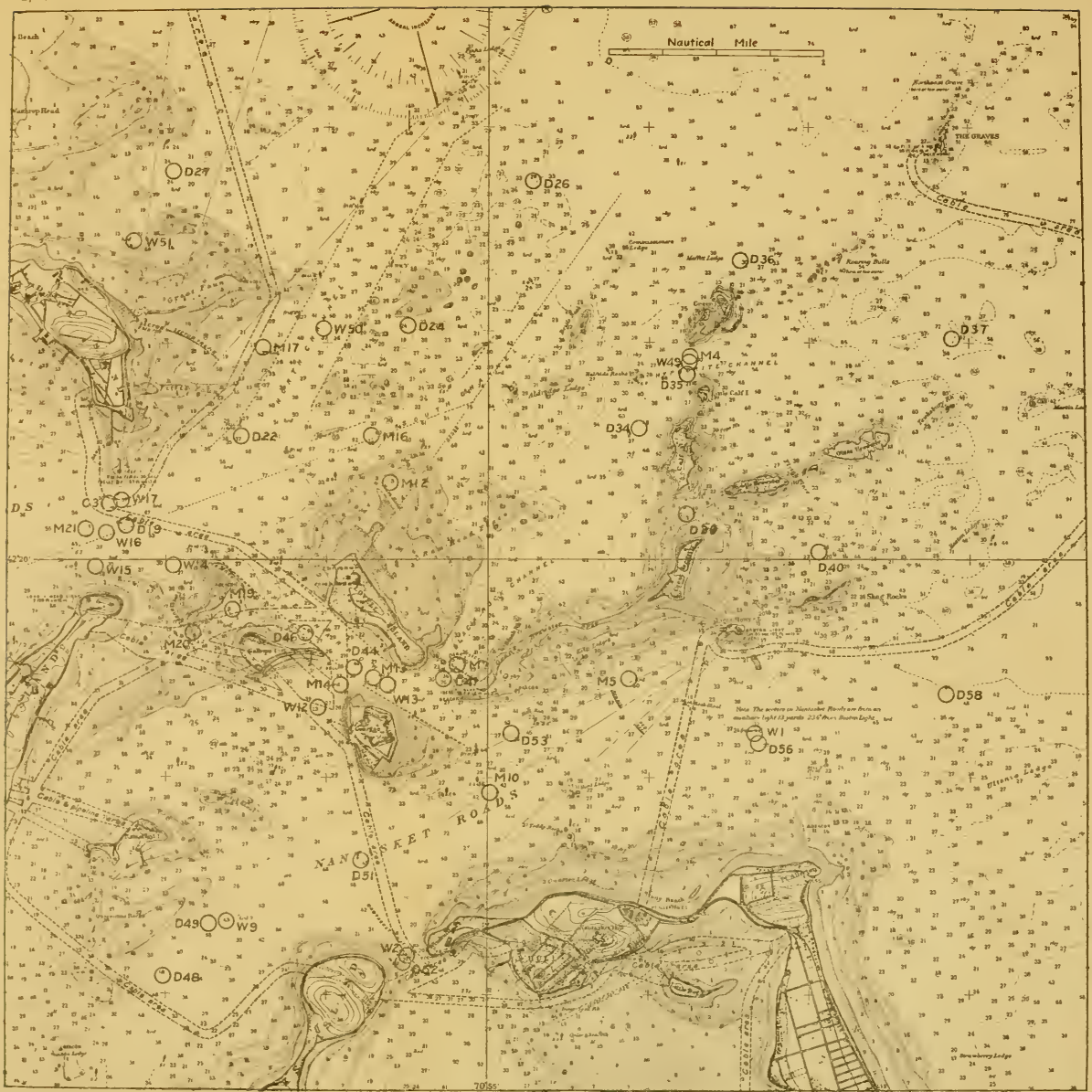

FIg. 7. - CURRENT STATIONS, APPROACHES TO BOSTON HARBOR AND NANTASKET ROADS 


they represent the currents near the surface. Directions of the current were obtained by angles between the float and objects on shore.

The results from these observations are shown in Table 31 . The station numbers refer to those assigned in the original reductions but are prefixed by the letter "D" to signify that they are stations occupied by the party of Lieutenant Davis. Numbers omitted refer to stations for which insufficient data were obtained or to stations which were reoccupied after a preceding number had already been assigned. Following the location and dates on which the observations were made, the length of observations is given to the nearest half or whole day.

The times of the slacks and strengths are referred to the tides as observed at the Boston Navy Yard, the slack before flood and the flood strength being referred to the low waters and the slack before $\mathrm{ebb}$ and ebb strength to the high waters. In general the current phases follow the tidal phases to which they are referred, but if the current occurs earlier than the tide, it is indicated in the table by a minus (-) sign. The time differences are given in hours and decimals.

The direction for the flood and ebb strength is reckoned in degrees from the true north as $0^{\circ}$, through east as $90^{\circ}$, south $180^{\circ}$, and west $270^{\circ}$. The velocities of the flood and ebb strength have been corrected by factors depending upon the range of tide at the navy yard.

The flood duration from slack before flood to slack before ebb and the ebb duration from slack before ebb to slack before flood are given in hours and decimals.

Mean current hour.-The mean current hour as given in this table is expressed in solar time and is the mean interval between the transit of the moon over the meridian of Greenwich and the time of the strength of the flood current modified by the times of slack water and strength of ebb. In computing the mean current hour an average is obtained of the intervals for the following phases: Flood strength, slack before flood increased by one-fourth semilunar day (3.10 hours), slack after flood decreased by one-fourth semilunar day, and ebb strength increased or decreased by one-half semilunar day (6.21 hours). Before taking the average the four phases are made comparable by the addition or rejection of such multiples of the semilunar day (12.42 hours) as may be necessary.

\section{CURRENT OBSERVATIONS, 1860, 1861, AND 1863}

A survey of Boston Harbor was undertaken in 1860, and current observations were made between July 30 and October 10, 1860, under the direction of Assistant Henry Mitchell. Additional observations were made between August 4 and September 19, 1861, and between August 8 and August 29, 1863, under the direction of Assistant Mitchell.

Surface velocities were obtained by a log line. Observations for different depths were made by using two cylinders or two globes connected by wire, the upper cylinder or globe supporting the lower one, which was set at various depths. By this method the observed current was the resultant of the current at the surface and at the depth 
of the lower cylinder or globe. In these observations the direction of the current was obtained by angles between the float and objects on the shore.

The results given in Table 32 cover depths to 10 and 12 feet, and may therefore be considered as applying to the current at an average depth of 5 to 6 feet. The numbers for the stations occupied in 1860

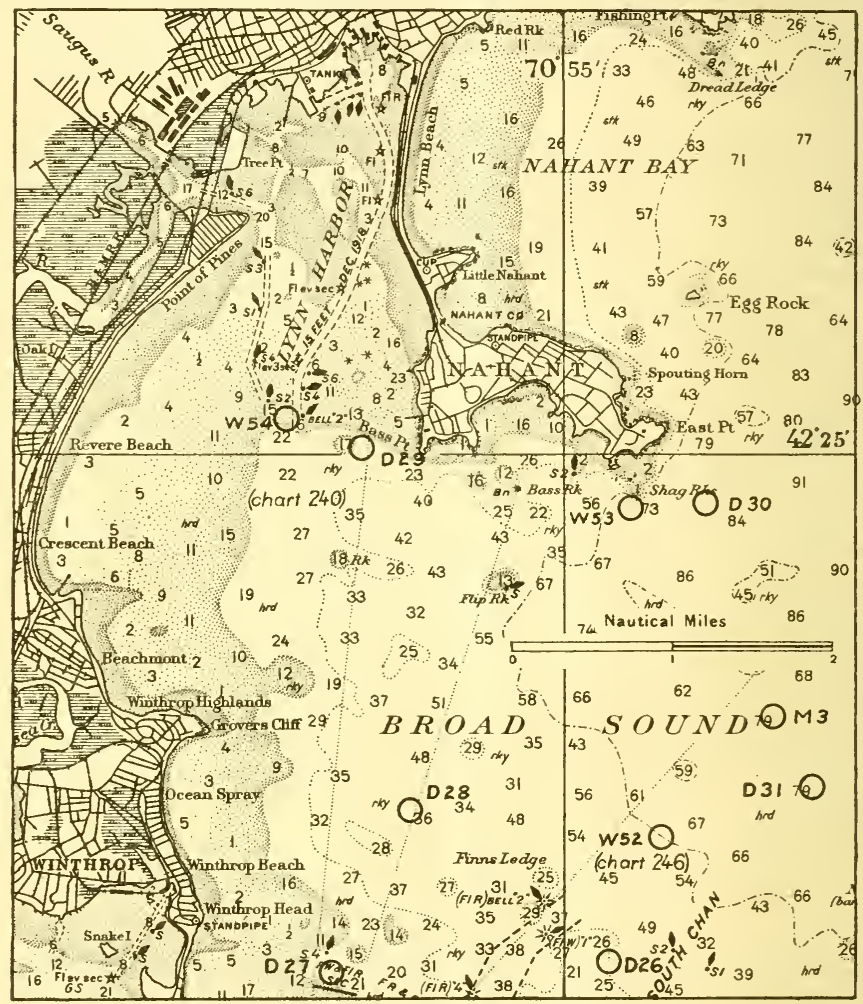

FIg. 8.-CURRENT STATIONS, BROAD SOUND

are the same as originally assigned, and following these the stations occupied in 1861 and 1863 are numbered in the order in which they were occupied. All the station numbers in this table are prefixed by the letter " $M$ " to signify that they were stations occupied by the party of Assistant Mitchell. Table 32 is similar to the preceding table which was explained on page 19 . 




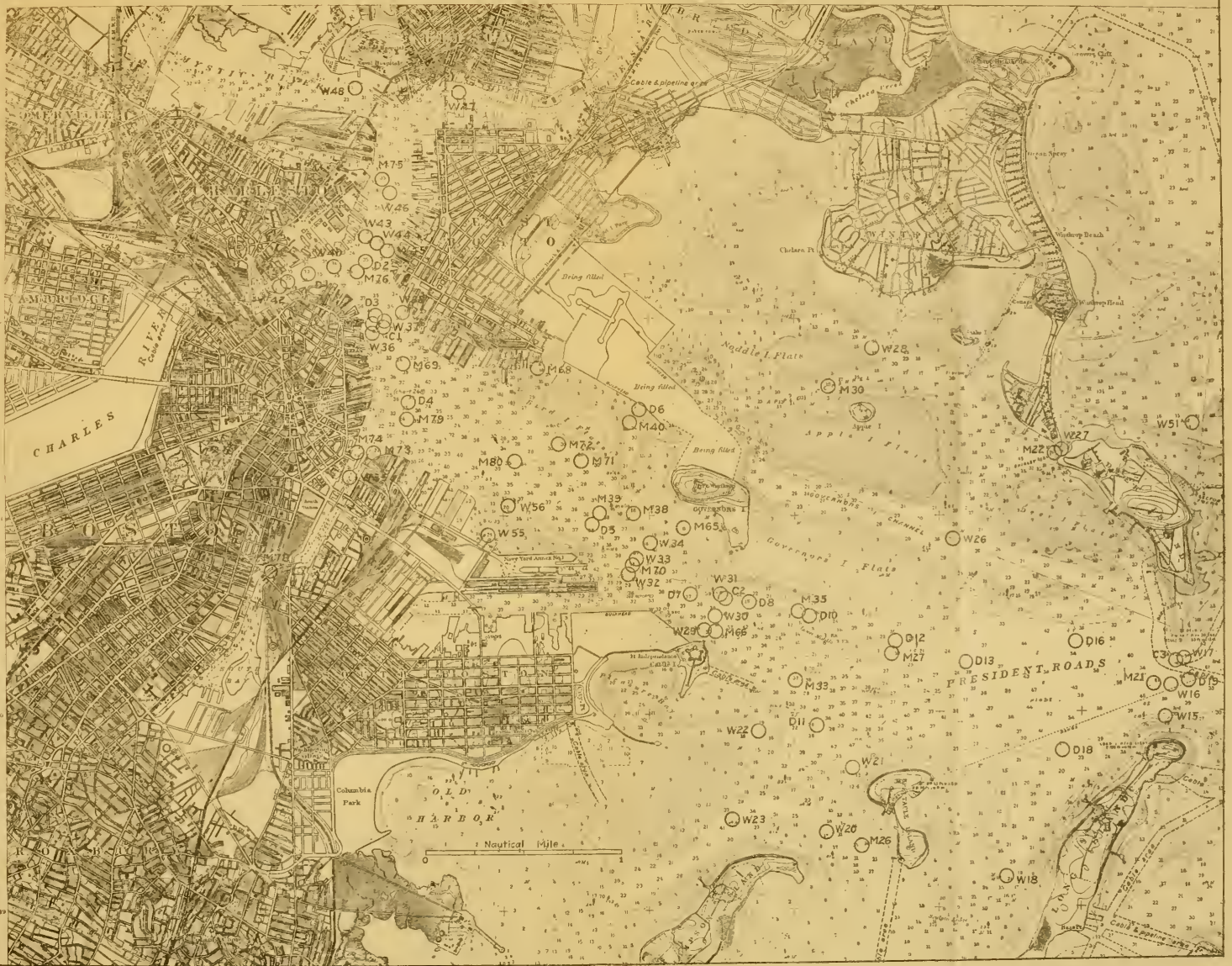





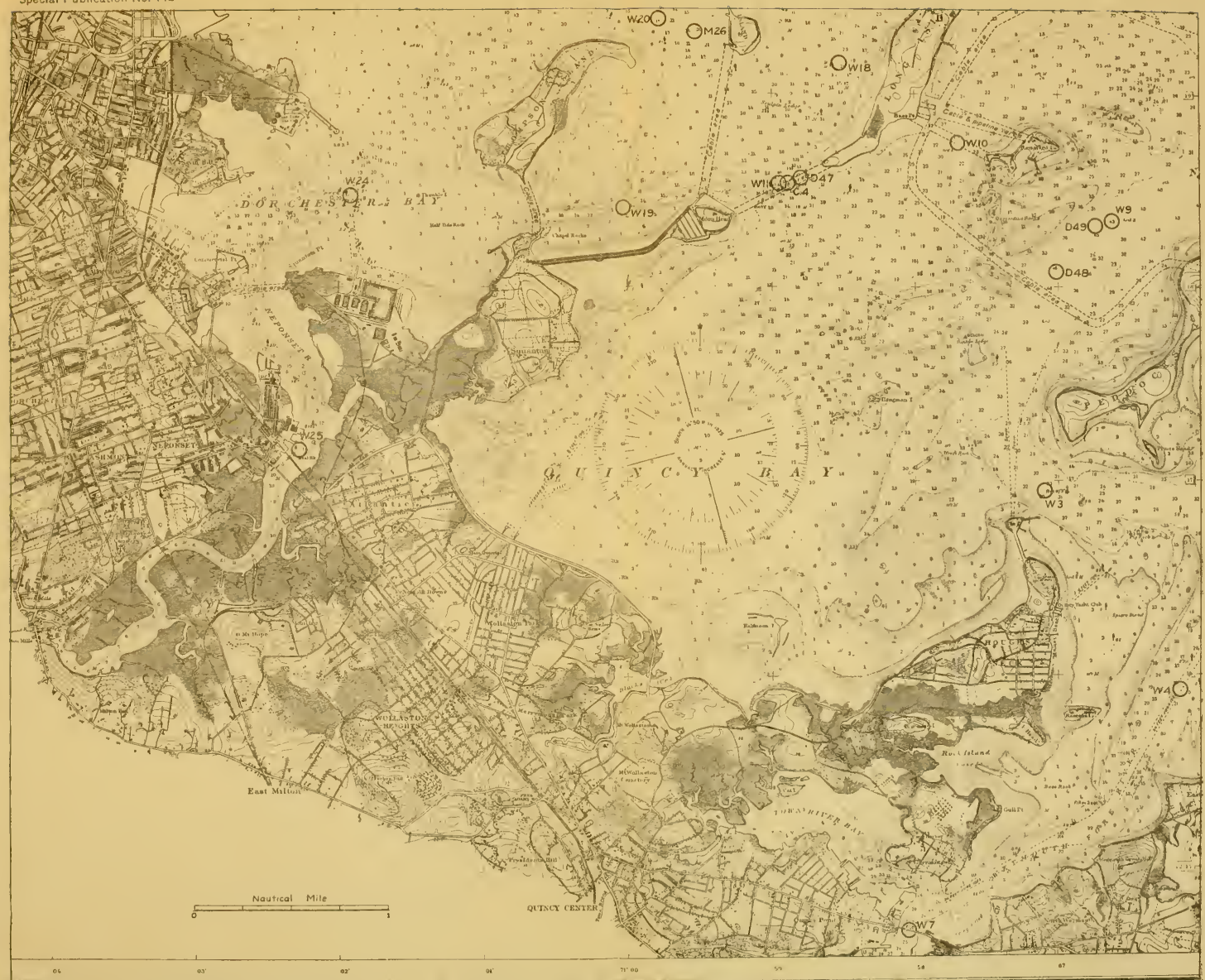





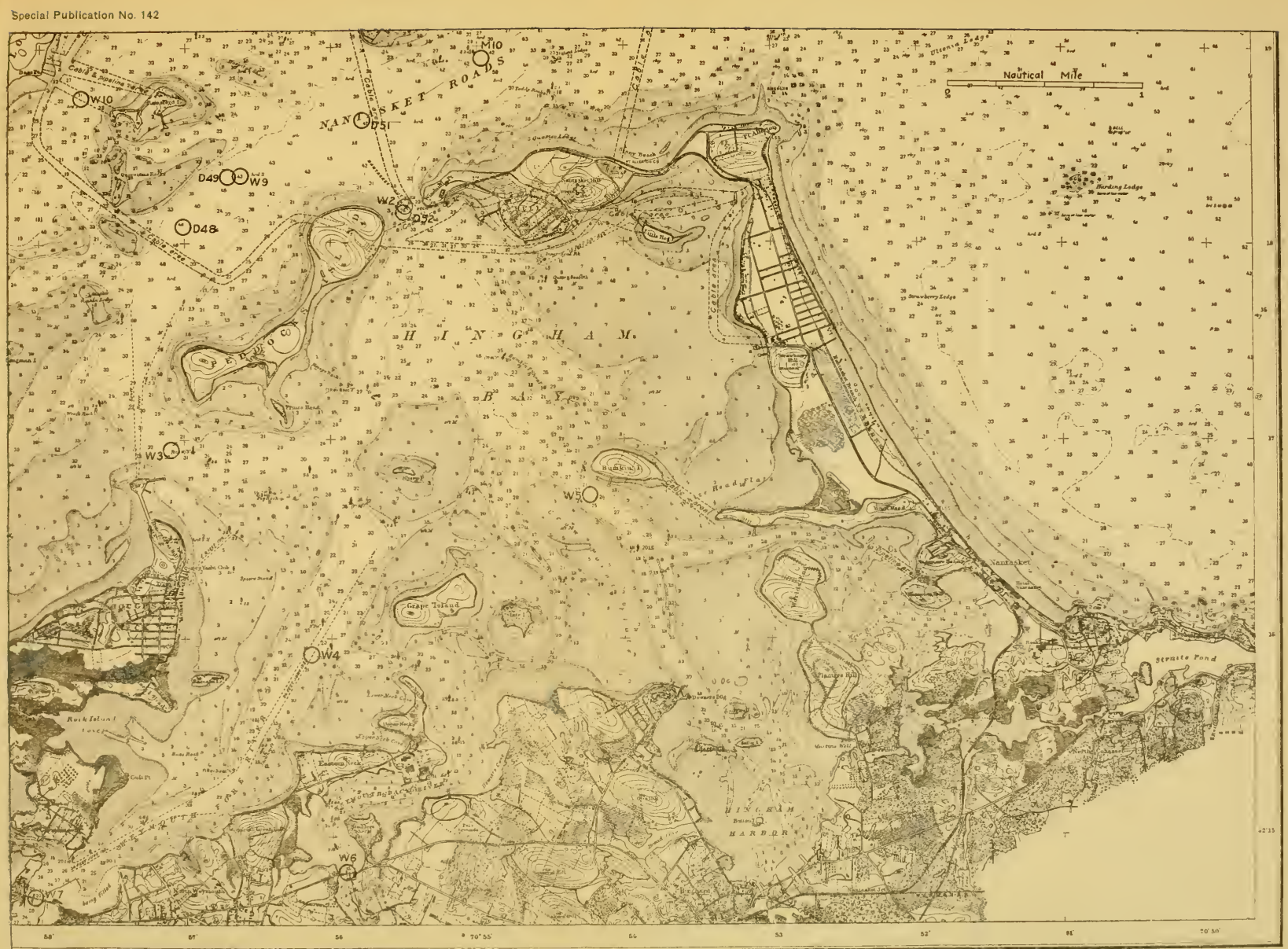



CURRENT OBSERVATIONS, 1902

In connection with a general survey preliminary to the construction of the Charles River Dam, the committee in charge obtained current observations at several points in Boston Harbor. These current observations were conducted by W. E. Spear under the direction of J. R. Freeman, chief engineer, and the results were published in 1903 by the committee on the Charles River Dam. They were made principally in the channels in four localities, between Boston and East Boston, between Governors Island and Castle Island, between Deer Island and Long Island, and between Long Island and Moon Head. In the first three localities named the observations were taken at five different depths, namely, near the surface, about one-third to bottom, one-half to bottom, two-thirds to bottom, and near the bottom. In the last lacation the observations were taken at four depths only.

The velocities were obtained by current meters, five different meters being used for the different depths. Three of these were Ritchie Haskell meters, one a Fteley \& Stearns meter, and the other an Ellis meter. The direction of the current was in general parallel to the axis of the stream.

The observations were made principally near the mid-channel, where the velocity is greatest, but there were also some observations made at a number of points in the sections across the channels. The results in Table 33 are from the observations in the mid-channel and refer to the several depths indicated. In this table the station numbers are prefixed by the letter " $\mathrm{C}$ " to signify that the observations were made by the committee on the Charles River Dam.

\section{CURRENT OBSERVATIONS, 1926}

A special tidal current survey of Boston Harbor was begun June 8, 1926 , by a party under the direction of $R$. W. Woodworth, of the Coast and Geodetic Survey. The work was continued until August 11,1926 , when the party proceeded to Portsmouth, N. H., for a survey of that locality.

Equipment.-The floating equipment included the two wire-drag launches, Ogden and Rodgers, and the launch Helma, a 55-foot boat which was leased for the period of the survey. In addition to these three launches which were used in the observation of currents, the launch Treasure Trove, a 40 -foot boat, was leased as a dispatch boat and was also used for observing currents. Each of the three larger launches had accommodations for a crew of eight men, while the smaller launch had accommodations for six men. All launches were equipped to remain on station for periods of one week at a time. The principal current apparatus ${ }^{1}$ in use consisted of current poles, Price current meters, and bifilar current indicators. There was also in use a Pettersson current meter.

Current pole.- The current poles were used in obtaining the direction and velocity of the current near the surface. The pole generally used was 15 feet long and weighted to float uprightly with 1 foot of its length above the water surface. Such a pole would therefore indicate the resultant current for the first 14 feet of depth, which

${ }^{1}$ A pparatus used in current surveys is described in considerable detail in Specisl Publication 124 of the C. \& G. Survey. 
may be considered as referring to an average depth of 7 feet. For very shallow depths shorter current poles were used.

The line attached to the pole was so graduated that the observer determined the velocity in knots by the number of divisions that passed over a given point during an interval of one minute. To permit the pole to get a sufficient distance beyond the disturbed waters near the launch and also to attain the velocity of the current before observing, a stray line of approximately 100 feet in length was used between the graduated line and the pole.

The direction of the current relative to the boat was obtained by means of the pelorus, a graduated dial arranged in a convenient place on the boat so that the current line would pass over its center as the pole was carried out by the current. The direction of the vessel's head being known by the compass, the direction of the current for each observation was readily calculated, corrections being applied for the deviation and variation of the compass.

Price meter.-Price current meters were generally used for the lower depths. These meters indicate velocity only. Meter cups rotating with the current cause an electric contact to be made at each turn of the cups, or, with a device known as the pentahead used for the greater velocities, at each five turns of the cups. These contacts are audible to an observer with ear phones on board the boat and indicate the velocity of the current by their frequency. Each meter in use during the survey was tested by the United States Bureau of Standards, and a rating table was prepared, showing the velocity of the current corresponding to different rates of rotation of the meter cups.

In order to expedite the raising or lowering of the meter to any desired depth and at the same time to prevent it being carried sidewise by any strong current, a guiding cable held vertically by a heavy weight was used. The meter, which was raised and lowered by its own cable, was shackled to the guiding cable in such a manner as to permit it to slide up and down as desired.

Bifilar indicator. - To obtain the direction of the current at the different depths at which the velocities were obtained by the Price current meter, an apparatus known as the bifilar current indicator was used. This device enabled the direction of the current at three different depths to be determined simultaneously. Three vanes, each supported by two parallel wires, were arranged so that they could be lowered independently to the depths desired. The supporting wires were connected with frames which turned with the vanes. Indicators attached to the frames, passing over peloruses, gave the direction of the current relative to the vessel's heading.

Pettersson meter. - A Pettersson current meter was also used in this survey, but as only a single meter of this type was available observations were made principally with the Price meter and the current pole. At several current stations the Pettersson meter was used in connection with the Price meter with very satisfactory agreement in results.

The Pettersson meter is designed to give a photographic record of both the velocity and direction of the current and will operate automatically for a period of two weeks. A water-tight cylinder contains a tiny camera with a roll of film moved by clockwork, a small electric lamp with batteries, a glass velocity disk with numerals inscribed near the outer edge, and a glass compass disk carrying two magnetic needles and inscribed with numerals to indicate direction. 
The compass dial is free to move so that the needles may assume a north-and-south direction. The velocity dial, through a system of reducing gears and parallel magnets, rotates with an anemometer wheel which is actuated by the current. At intervals of 30 minutes the electric lamp is automatically flashed and a picture is taken showing certain numerals on the velocity and compass dials. The numeral on the velocity dial indicates the accumulated motion of that dial due to the movement of the current. The difference between two successive readings, as interpreted by a rating table, gives the average velocity of the current for the half-hour period. The numeral on the compass dial indicates the direction of the current at the moment the picture was taken.

Stations occupied.-During this survey 56 current stations were occupied in Boston Harbor, the locations being indicated in Figures 7 to 11 . At stations W1, W16, and W37 the observations covered periods from 6 to 14 days. At the other stations the period of observations ranged from one-half to two days.

In general observations were made at each station with both the current pole and the Price meter, the latter being set at depths approximately equal to two-tenths, five-tenths, and eight-tenths of the depth at each station. These observations were usually made in groups at half-hourly intervals, each group consisting of a pole observation and two meter observations at each of the depths, the direction of the current at each depth being obtained by the bifilar current indicator. Supplementary observations with the Pettersson meter were obtained at stations W2, W5, W9, W10, W33, W49, and W54, the results practically agreeing with those obtained by the Price meter.

Reduction of records.-Following the method generally employed in the reduction of current observations, the velocities as observed at approximate half-hourly intervals were plotted on cross-section paper with the flood velocities above and the ebb velocities below the zero line representing slack water. A smooth curve was then drawn following the general line of the plotted velocities. From these curves the times of slack water and the times and velocities of the current at strength of flood and ebb were tabulated.

The times of slack water and strength of current were then compared with the times of high and low water at the primary tide station at Commonwealth Pier No.5, and the observed velocities were reduced to mean velocity by comparison with the range of tide at the primary tide station. The directions of the current as observed on the pelorus were corrected for ship's head and the variation and deviation of the ship's compass and are therefore represented in true azimuth as reckoned from the north toward the east.

The reductions were made separately for each depth at which observations were taken, and the results are given in Table 34 . The station numbers are as originally assigned in the survey, with the letter "W" prefixed to indicate that the stations were those occupied by Lieutenant Woodworth in 1926.

Harmonic analysis.-The hourly velocities at stations W1, W16, and W37 were reduced by harmonic analysis. Station W1 is located at the entrance to Nantasket Roads, Station W16 is at the entrance to President Roads, and Station IV37 is in the channel between 
Boston and East Boston. The total lengths of series used for the analyses at these stations were 5,14 , and 6 days, respectively. For station W16 two separate analyses were made, one for a 10-day series and the other for a 4-day series.

Because of the shortness of these series, the usual elimination processes were not applicable, but corrections were made by comparison with tidal harmonic constants derived from simultaneous tide observations at Commonwealth Pier No. 5, Boston. The analyses were made for components $\mathrm{M}_{2}, \mathrm{M}_{4}, \mathrm{M}_{6}, \mathrm{~N}_{2}, \mathrm{~S}_{2}, \mathrm{~K}_{1}$, and $\mathrm{O}_{1}$, and values for other components were inferred from these principal components and from the tidal components for Boston. The harmonic constants are given in Table 35.

The consistency of the results derived from the several series indicates that the semidiurnal components for these stations have been reasonably well determined, notwithstanding the shortness of the series of observations upon which they are based. The constants derived for the diurnal components, especially the epochs for these components, are less well determined. Because of the small amplitude of these components and also of components $\mathrm{M}_{4}$, and $\mathrm{M}_{6}$, the epochs are very sensitive to any small irregularities introduced by accidental conditions. On the other hand, the small amplitudes of these components in this locality render them of little practical importance.

Station W16, off Deer Island Light at the entrance to President Roads, is a principal current station for which predictions are given in the current tables published annually by this bureau. Hereafter these predictions wil. be based upon the harmonic constants in Table 35.

\section{CURRENT OBSERVATIONS, BOSTON LIGHT VESSEL}

There have been two series of current observations at the Boston Light Vessel in accordance with a general plan for obtaining such observations through a cooperative arrangement between the Coast and Geodetic Survey and the Bureau of Lighthouses. The first series of current observations at the Boston Light Vessel covers the period September 22 to December 26, 1913, and the second series June 8, 1926, to June 30, 1927. The apparatus consisted of a $\log$ line graduated for a run of 60 seconds, a 15 -foot current pole weighted to float with 1 foot of its length above water, a pelorus, and a stop watch or sand glass, the latter having been used for the earlier obserrations. An observation was taken each hour of the day.

The tidal current in this locality is weak and slightly rotary and is affected to a considerable extent by the wind. In general the velocities are less than one-half knot. The maximum velocity recorded was 1 knot, which occurred on April 7, 1927, during a northwest gale and at a time when the normal tidal current would have been easterly. The wind therefore tended to increase the normal velocity and also to divert the direction of the current to the south of east.

Tidal current.--In reducing these records the observed velocities were resolved in north and east directions and then referred to the times of high water at Boston, the earlier series being referred to the predicted tides for the navy yard and the later series to the observed 
tides at Commonwealth Pier No. 5. The average velocity and direction of the current for each hour after high water are given in Table 36. The average times for the slacks and the strengths for both series are referred to the tides at Commonwealth Pier No. 5, and the velocity and direction at the strength of flood and ebb are also given. The average velocity of the tidal current at strength of flood and ebb is only 0.1 knot. This velocity, being derived from resolved currents, grouped according to the number of hours after high water, is less than would be obtained by selecting the maximum velocities during the periods of flood and ebb regardless of tidal hour or exact direction. The average velocity for both flood and ebb current obtained by such a selection for a 29 -day period was 0.3 knot.

Set of current.- - In Table 37 there is given the set of the nontidal current for each month of observations. This set is very irregular, and the velocity is too small to be of practical importance. The resultant set from the longer series is in an easterly direction with a velocity of 0.02 knot. Because of the irregularity in the direction of the set from month to month, this velocity derived from the resolved currents for the entire series is less than the average of the set for each month taken regardless of direction.

Wind reduction.- In order to determine the effect of the wind on the current in this locality, the resolved currents were grouped in accordance with the direction of the wind, and the results are given in Table 38. The current due to the wind had an average velocity from 0.06 to 0.19 knot in a direction usually somewhat to the right of the direction toward which the wind was blowing.

Harmonic analysis.- The resolved hourly velocities for a 221-day series beginning June 9, 1926, were reduced by harmonic analysis, separate analysis being made for the north and east components. The resulting values for the principal components are given in Table 39 . As the currents in the locality are chiefly in an easterly and westerly direction, the values of the $H$ 's for the east component are somewhat larger than the $\mathrm{H}$ 's for the north component. The east component of principal element $\mathrm{M}_{2}$ has an amplitude of 0.08 knot, which is consistent with the velocity of the tidal current as given in Table 36 .

\section{SUMMARY OF SURFACE CURRENTS}

For the navigator the currents near the surface are of principal importance, and for convenience the results for these currents from the several surveys are brought together in Table 40 and grouped according to location. For the purpose of this table averages have been taken of the results from the pole observations and from the meter observations to a depth of 14 feet, and the times of slack and strength of current for all stations are referred to the tides at Commonwealth Pier No. 5, in order that they may be comparable with each other:

The results from the observations at the various stations listed in this table show a number of minor irregularities. Some of these may be due to location. The current near the shore may differ considerably from that in the middle of the channel, and the current at stations near each other may sometimes vary in time, velocity, and direction. Some of the irregularities may be due to changes in the con- 
figuration of the harbor, and the currents observed during the later surveys may actually differ from those of earlier surveys. Many of the small irregularities, however, may be the result of accidental conditions prevailing at the time of the observations. Only in a few instances did the observations at any station cover more than two days, and in many cases the period was one day or less. There was therefore no opportunity to average out any accidental errors that might have resulted from special conditions prevailing on the day or days on which the observations were made.

The tidal currents have access to Boston Harbor through two main channels, President Roads and Nantasket Roads. In general the times of the current phases do not differ greatly in different parts of the harbor. The slack before flood occurs near or soon after the time of low water and the strength of flood from three to four hours later.

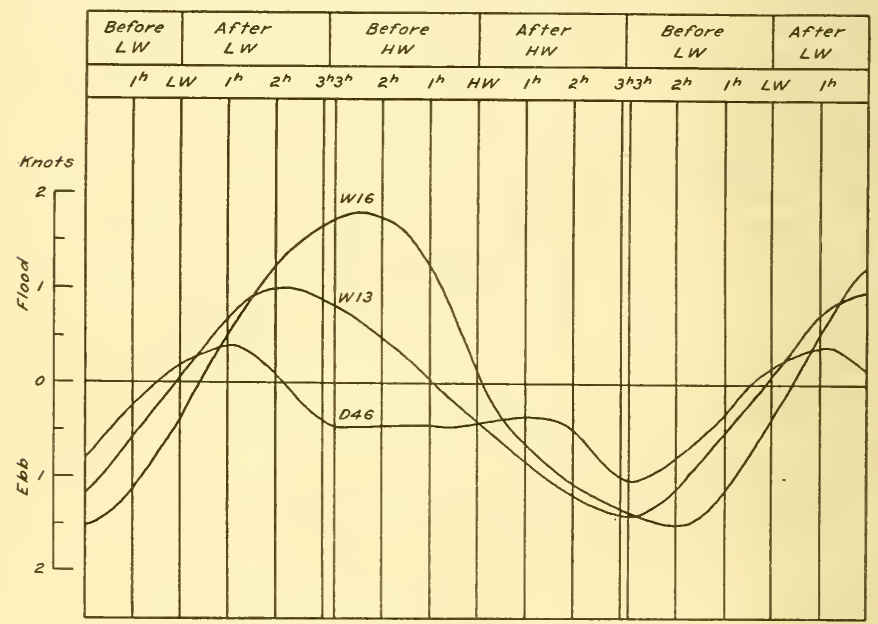

Fig. 12. - TYPICAL CURRENT CURVES FOR STATIONS D46, W13, AND W16

The slack before ebb occurs near the time of high water and the strength of ebb from three to four hours later.

The Narrows.-The Narrows (see fig. 7) is a channel leading into Boston Harbor from the southeastward, with Lovell Island on the northeast and Georges Island and Gallups Island on the southwest. In this locality the main flood and ebb streams appear to flow westerly and easterly, passing between Georges Island on the south and Lovell and Gallups Islands on the north. In that part of the Narrows lying between Lovell and Gallups Islands the currents appear to be somewhat irregular, as indicated by the observations made at the single station D46 in the year 1848. This is illustrated in Figure 12, in which a typical curve prepared from the current observations of 1848 at station D46 is compared with corresponding curves for station W13 between Lovell and Georges Islands and for station W16 at the entrance to President Roads. It shoulr. be kept in mind, 
however, that the observations at station D46 were made many years ago, and it is not impossible that changes such as the recent improvement in the North Channel may have materially affected the current in this locality.

Off Moon Head.-From an examination of Table 40 and by reference to Figure 10 it will be noted that in the passage between Moon Head and Long Island, and also between Thompson and Spectacle Islands, the results from the recent observations in 1926 differ materially from those of the earlier series in regard to the time of the turning of the current. The relation of the current from observations of 1848 at station D47 with the current in 1926 at stations W11 and W20, and also with the current at the principal current station W16, is illustrated in Figure 13. In the earlier observations the phase of the current corresponded approximately with those for the harbor generally

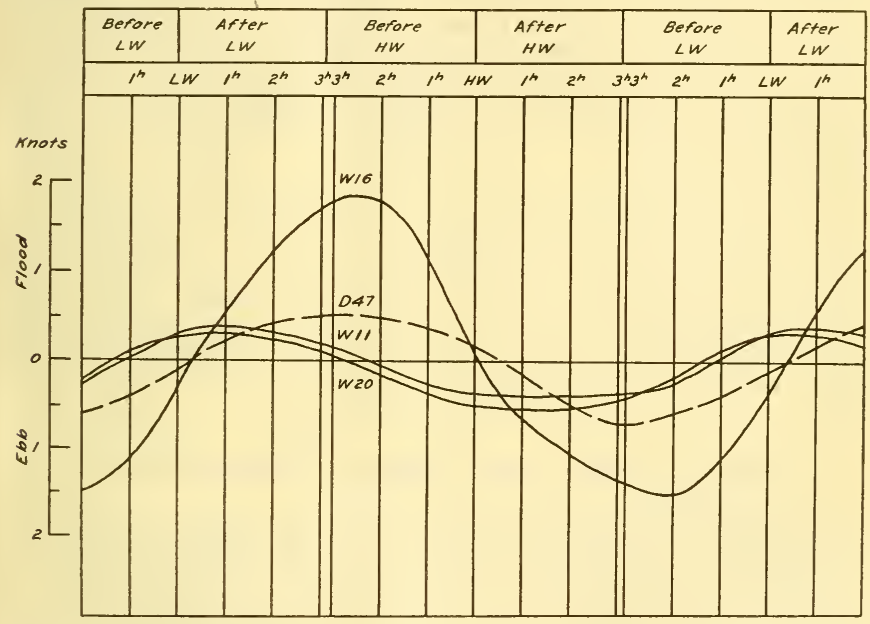

Fig. 13. -TYPICAL CURRENT CURVES FOR STATIONS D47, W11, W20, AND W16

but in the later series the times of the phases have been advanced two or three hours.

As these passages connect the main current stream through President Roads with the current stream entering Quincy Bay through Nantasket Roads, the currents through these passages are virtually cross currents which would depend to a considerable extent upon the relative volume of water passing through the main channels. Such currents might be affected to a considerable extent by changes in the configuration of the harbor.

Condensed current data.-For convenience of reference there have been compiled in Table 41 condensed current data for selected localities. The time differences refer to the current at the principal station IV16, off Deer Island Light at the entrance to President Roads. These differences, which are given to the nearest five minutes, represent the a verage differences for all phases of the current, including both the 
slacks and strengths of the current, the minus sign indicating that the current phases occur earlier than at the principal station and the plus sign that they occur later. The strength of flood interval is the average interval between the transit of the moon over the local meridian and the time of the following strength of flood. The direction of the strength of flood is given in degrees as reckoned from the true north by way of the east. The flood and ebb velocities represent the average velocities at the strength of flood and ebb. The observations at the current stations listed in the last column furnished the basis for the data given in this table, but small adjustments have been made, and the results are given in rounded numbers.

Current charts.-Currents in Boston Harbor are schematically represented for each hour of the tide at Commonwealth Pier No. 5 in Figures 14 to 25 , which are based primarily upon the observations of 1926. The general direction in which the current is flowing is represented by arrows and the average velocities in knots and tenths of knots by small figures near the arrows. At the times of spring and perigean tides the velocities will usually be greater and at the times of neap and apogean tides less than indicated. Winds and other meteorological conditions may also affect both the velocity and direction of the current.

Near the times of high and low water, the currents slacken and are more or less irregular in direction. The velocities, usually small at these times, are not included in the charts. The maximum velocity is reached three or four hours after high and low waters. The average velocity at strength of current through the entrances to the harbor is approximately $11 / 2 \mathrm{knots}$. Inside the harbor this velocity diminishes to about 1 knot or less, except that through Nantasket Gut east of Peddocks Island the average velocity at strength of current is $21 / 2$ knots.

\section{TEMPERATURE AND DENSITY OBSERVATIONS}

Temperature and density observations of the sea water in Boston Harbor have been made from time to time in connection with tide observations, and the mean results which are available have been compiled in Tables 42 to 44 . The results of such observations at the navy yard from February to December in 1863 are given in Table 42.

Incidental to the tide observations at Commonwealth Pier No. 5, South Boston, the observer takes a temperature and density observation of the sea water each day the tide station is visited. There are no requirements that he visit the station at any specified hour nor that the hour selected should be the same each day. Neither is he required to make these visits on Sundays or holidays. The times actually selected for the visits have probably covered nearly all hours of daylight but appear to be more frequent between 3 and 5 o'clock in the afternoon. It may be assumed that the observations are distributed approximately uniformly over all phases of the tide. The observed densities were corrected and reduced to temperature $15^{\circ} \mathrm{C}$. Table 43 contains the monthly means and extremes of the temperatures and densities observed.

Incidental to the special current survey of 1926, temperatures and densities were taken at three different depths at nearly all of the stations occupied. The densities were reduced to temperature $15^{\circ}$ C., and the results have been compiled in Table 44 . 


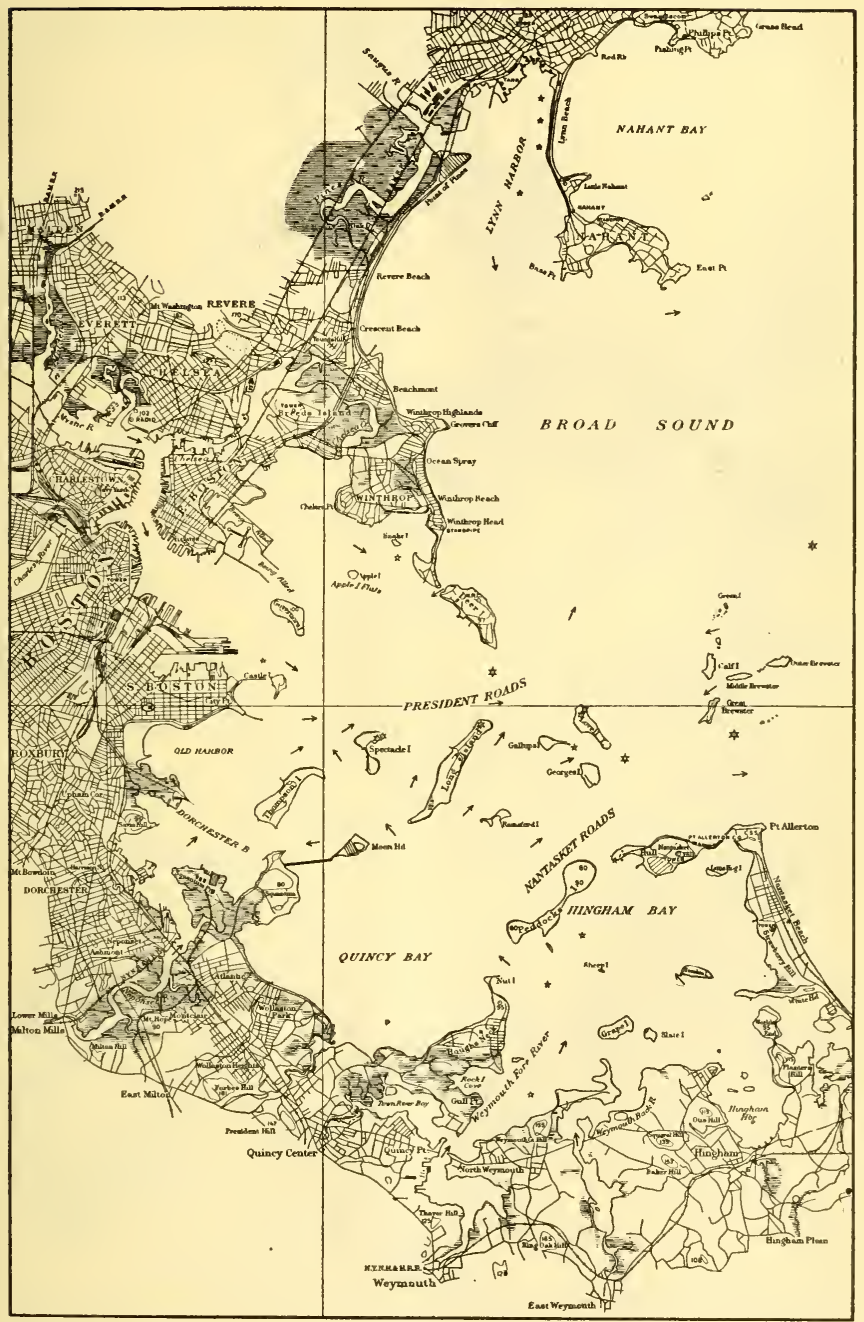

FIg. 14.-CURRENTS AT TIME OF LOW WATER AT COMMONWEALTH PIER NO. 5. END OF EBB, CURRENTS GENERALLY WEAK AND IRREGULAR $81772-28-3$ 


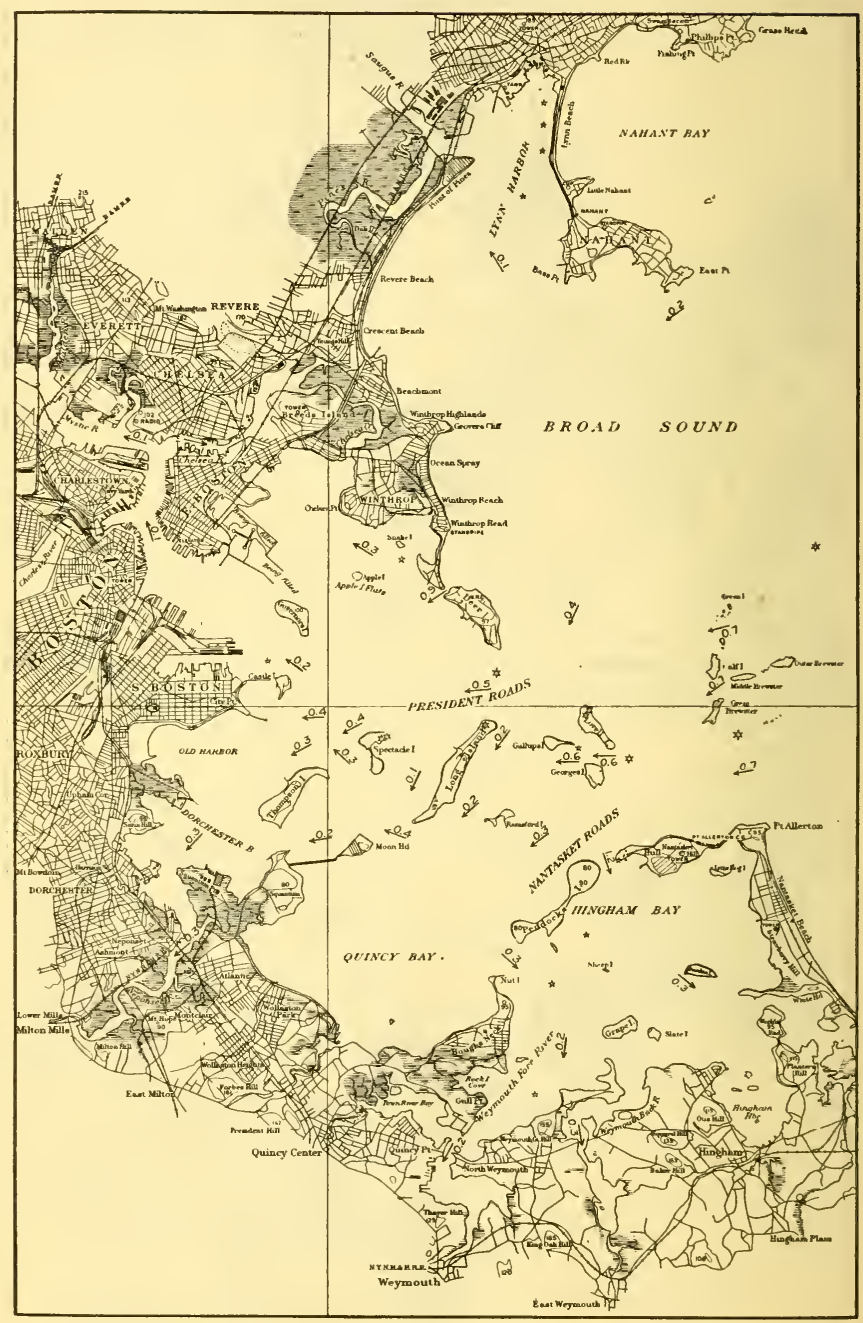

FIg. 15.-CURRENTS ONE HOUR AFTER LOW WATER AT COMMONWEALTH PIER NO. 5 


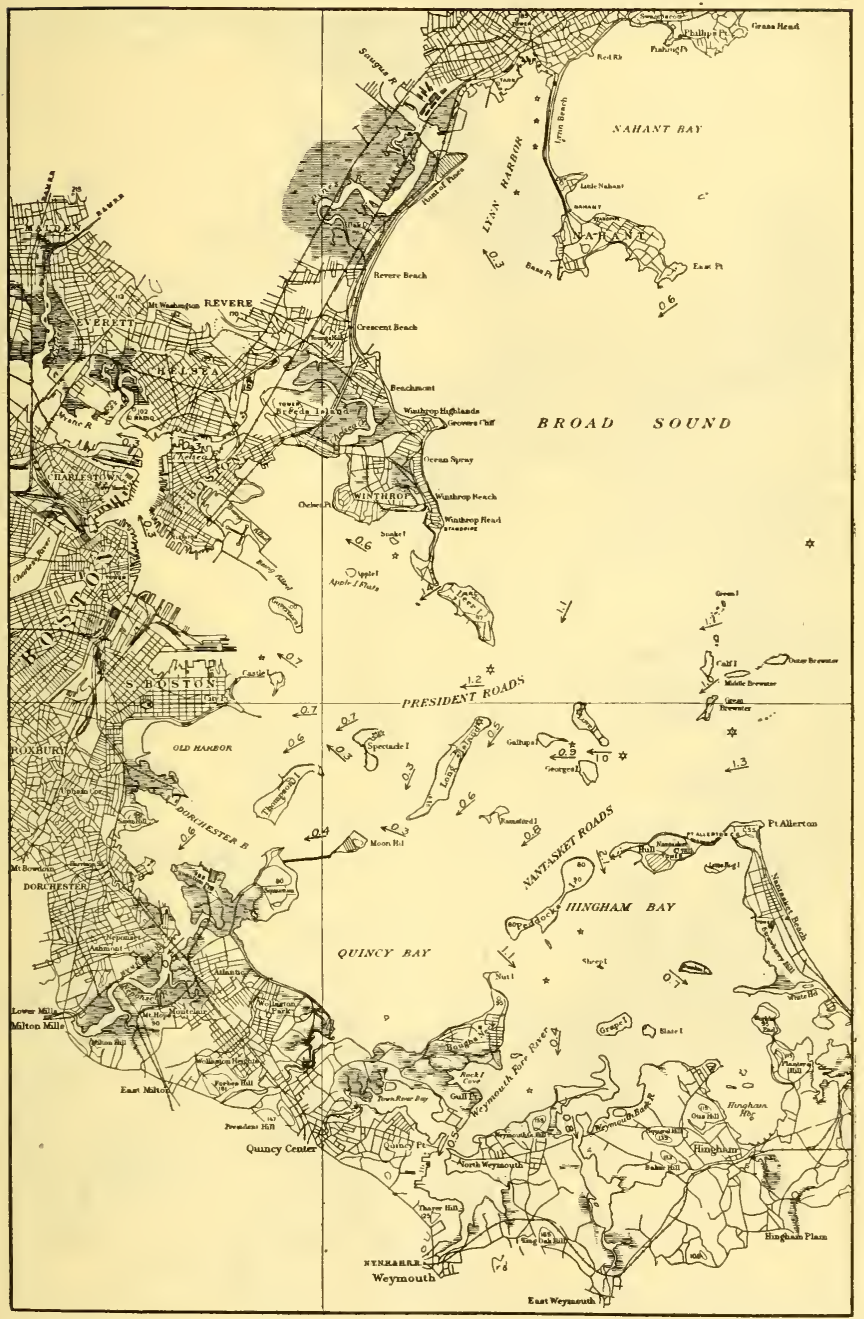
Fig. 16.-CURRENTS TWO HOURS AFTER LOW WATER AT COMMONWEALTH
PIER NO. 5 


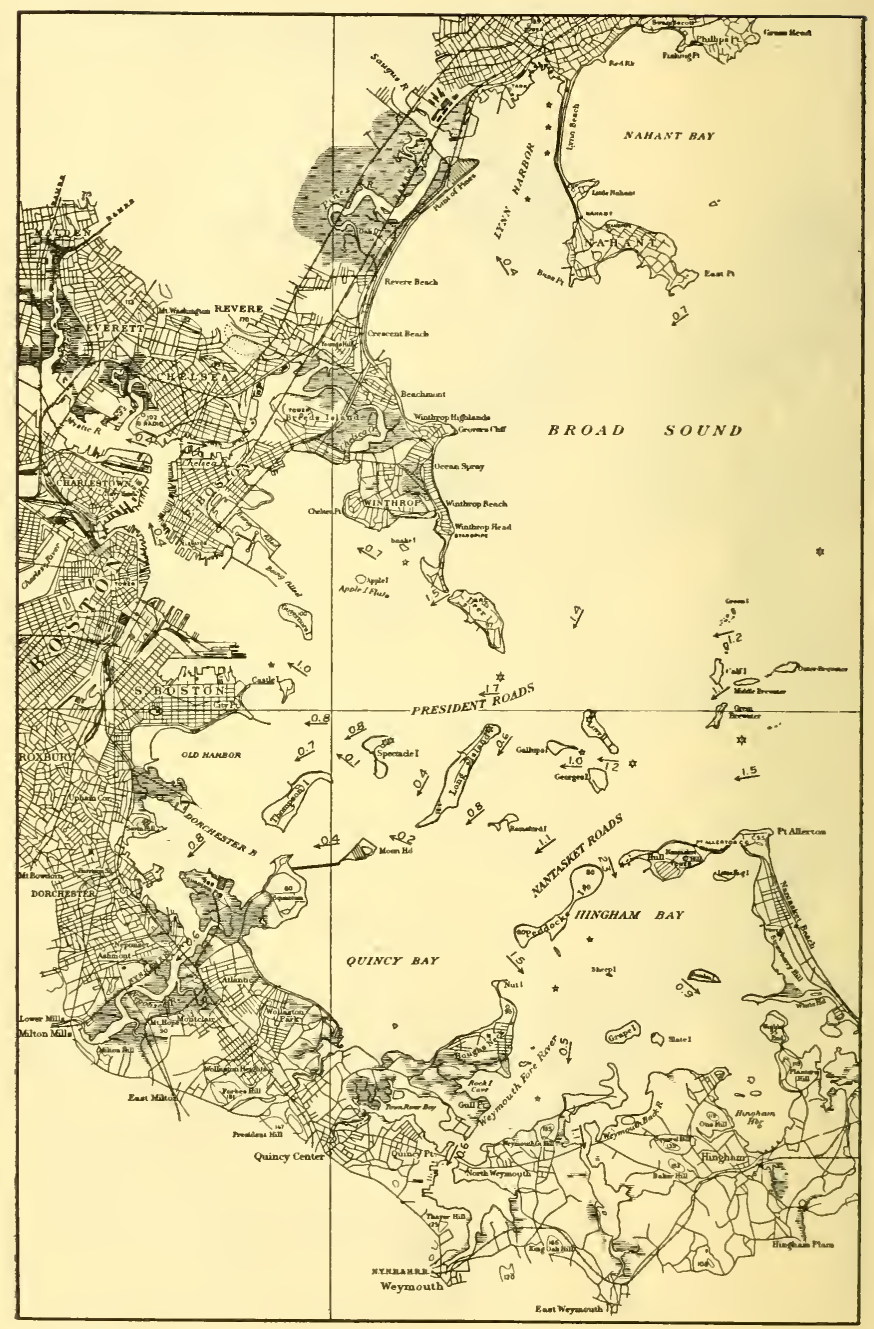

FIg. 17. - CURRENTS THREE HOURS AFTER LOW WATER AT COMMONWEALTH PIER NO. 5 


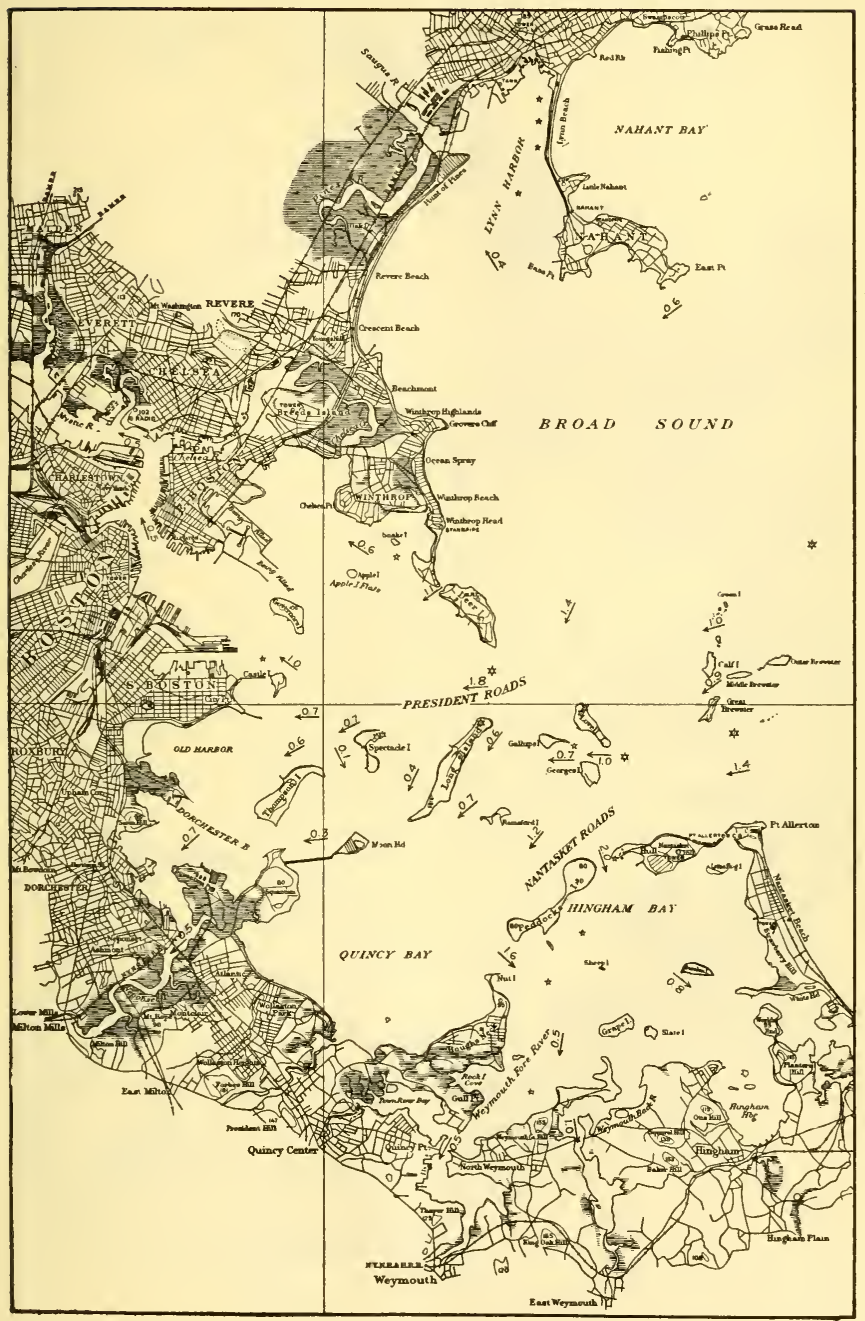

Fig. 18. - CURRENTS FOUR HOURS AFTER LOW WATER AT COMMONWEALTH PIER NO. 5 


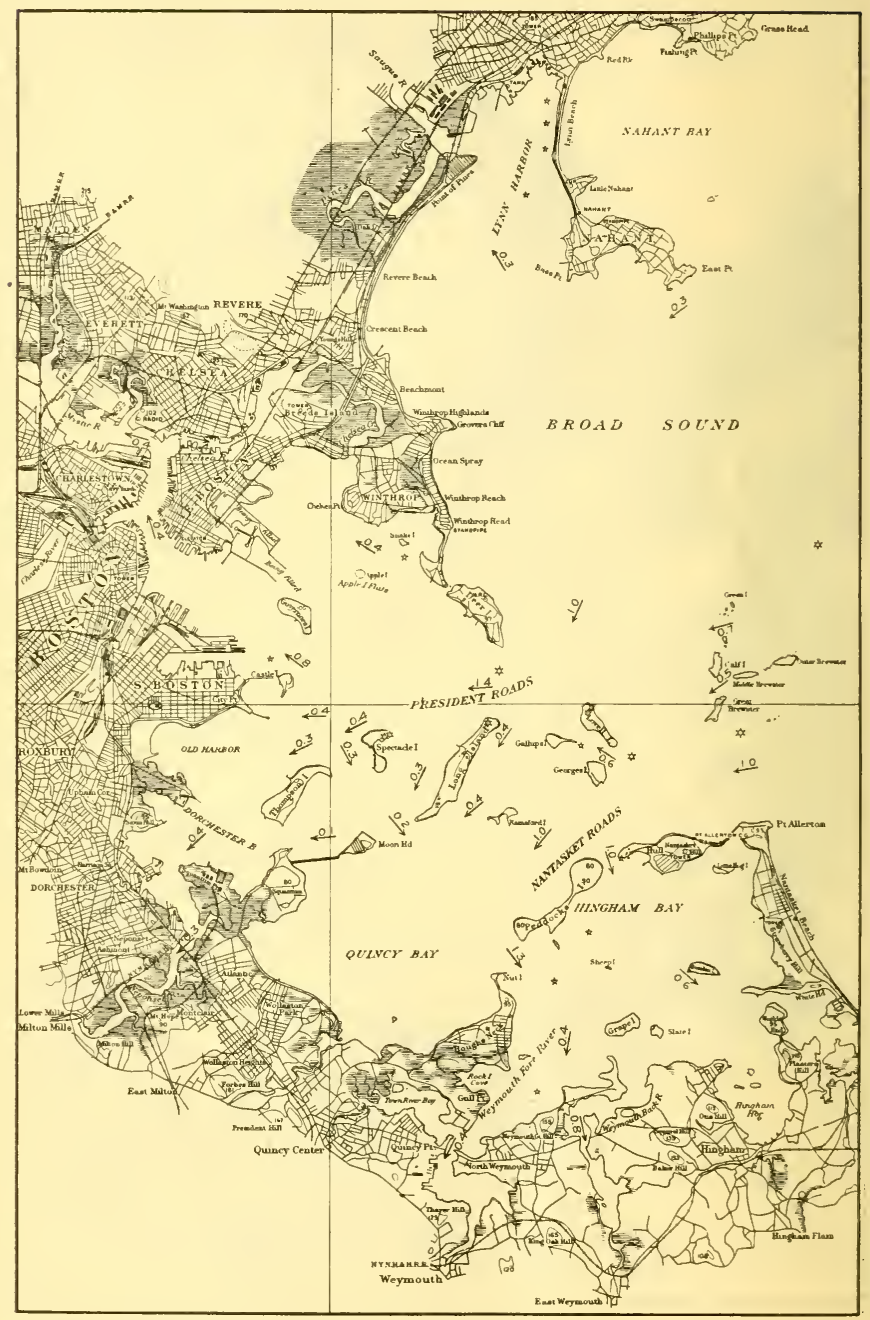

FIg. 19.-CURRENTS FIVE HOURS AFTER LOW WATER AT COMMONWEALTH PIER NO. 5 


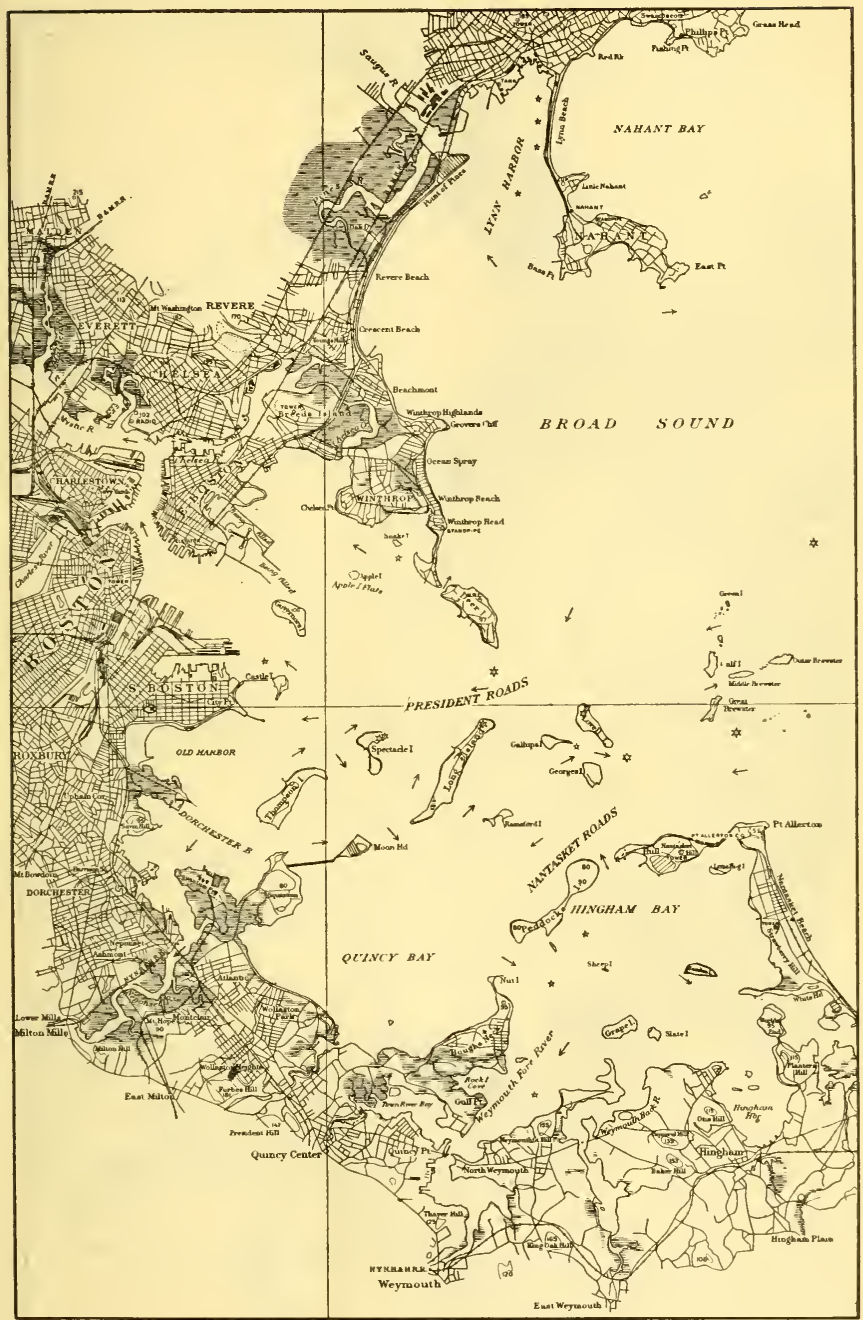

FIg. 20,-CURRENTS AT TIME OF HIGH WATER AT COMMONWEALTH PIER NO. 5. END OF FLOOD, CURRENTS GENERALLY WEAK AND IRREGULAR 


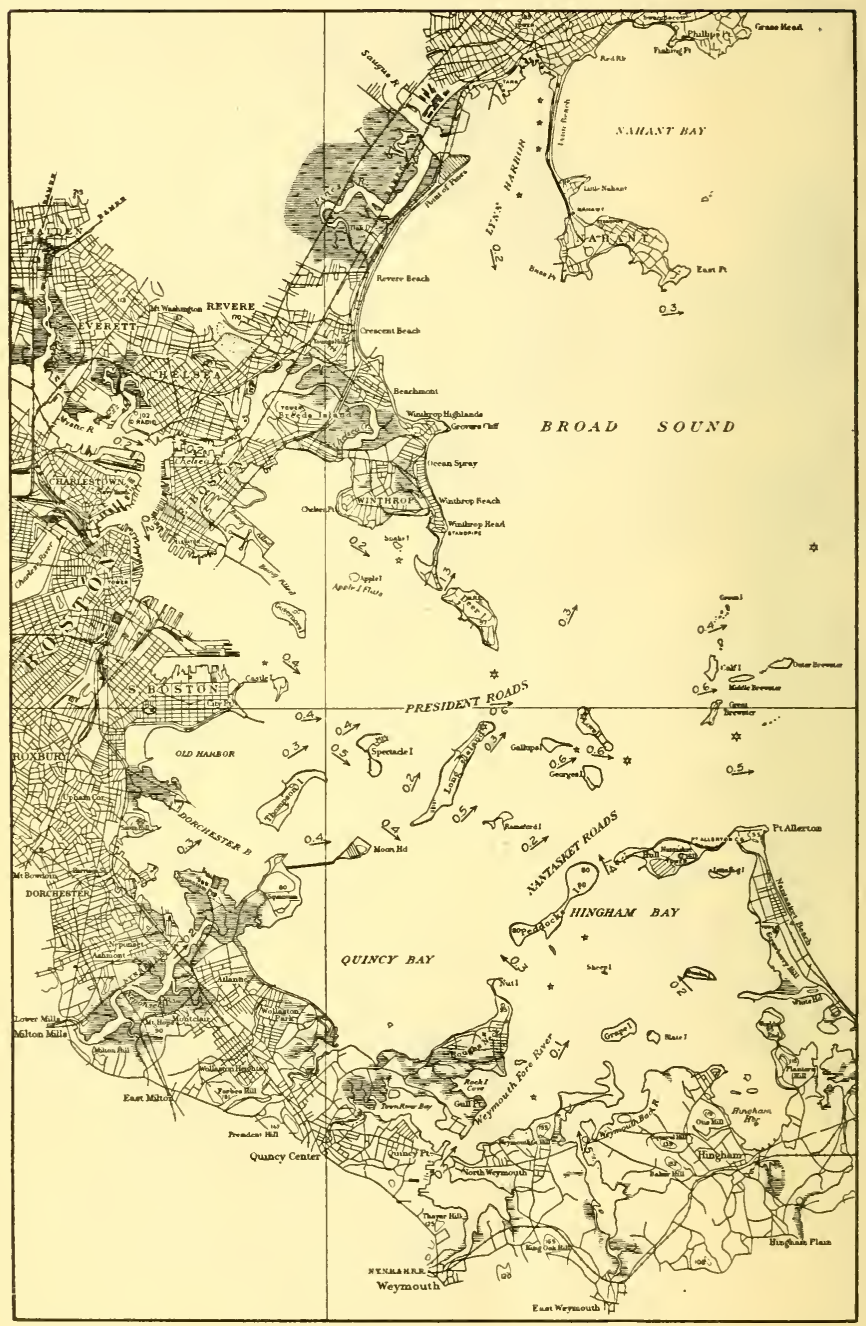

Fig. 21.-CURRENTS ONE HOUR AFTER HIGH WATER AT COMMONWEALTH PIER NO. 5 


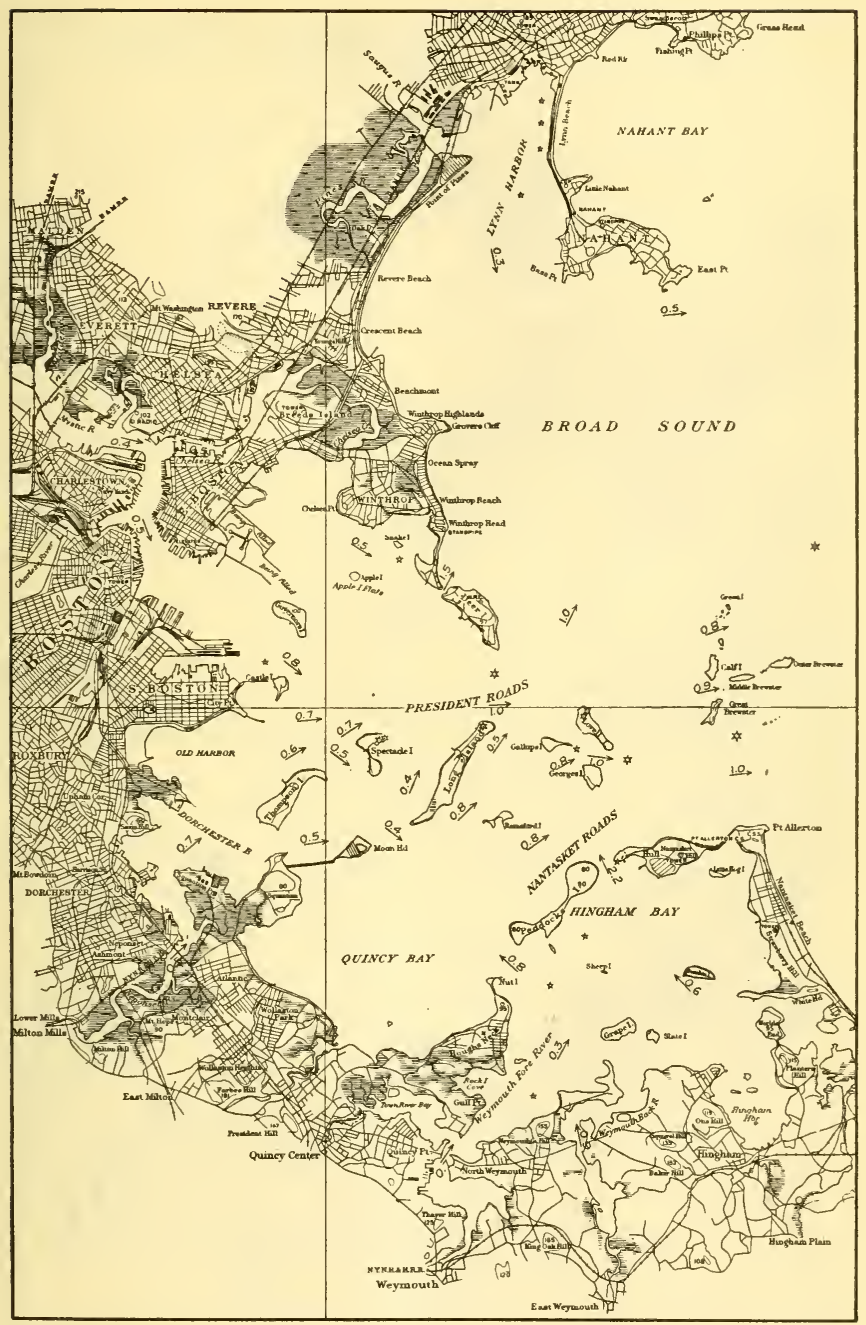

Fig. 22.-CURRENTS TWO HOURS AFTER HIGH WATER AT COMMONWEALTH PIER NO. 5 


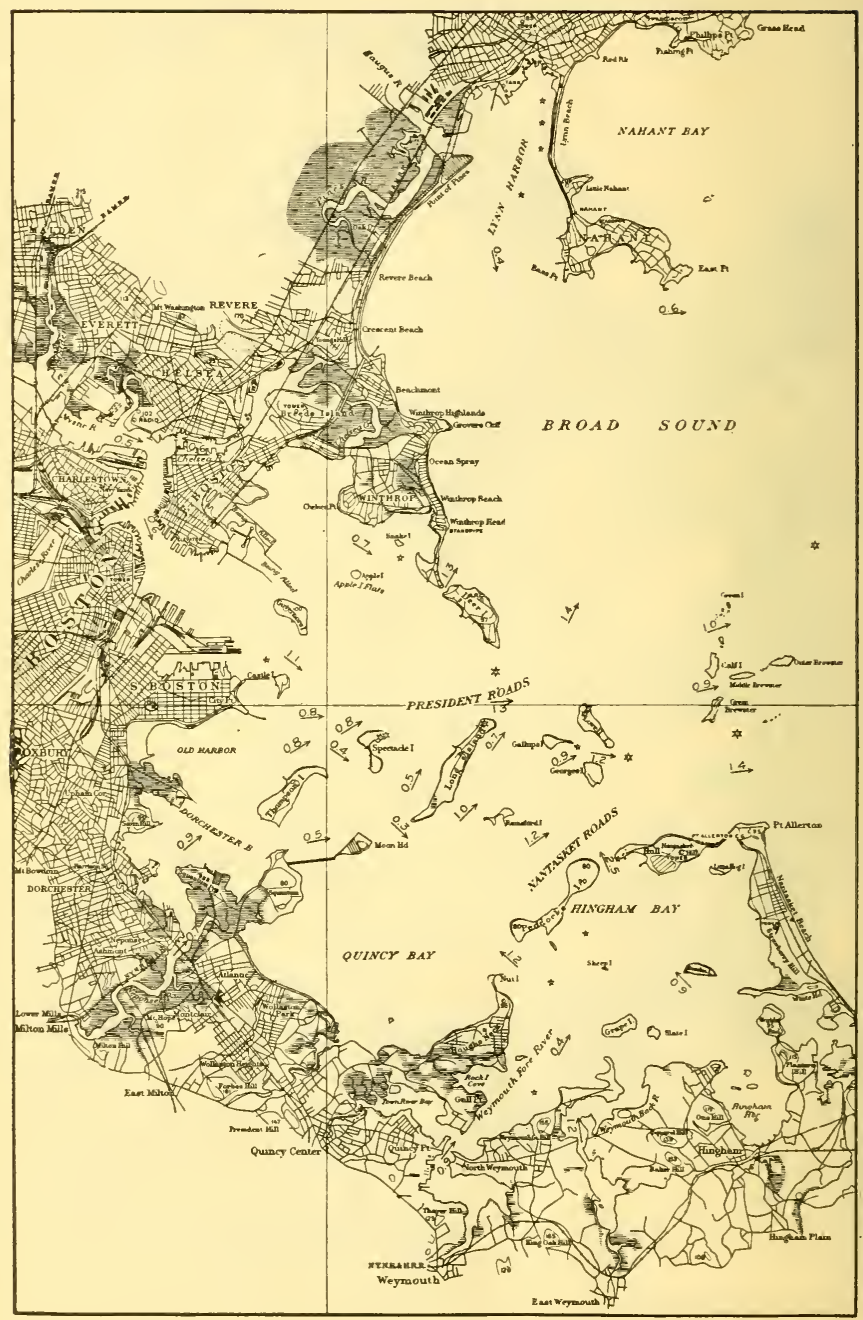

Fig. 23.-CURRENTS THREE HOURS AFTER HIGH WATER AT COMMONWEALTH PIER NO. 5 


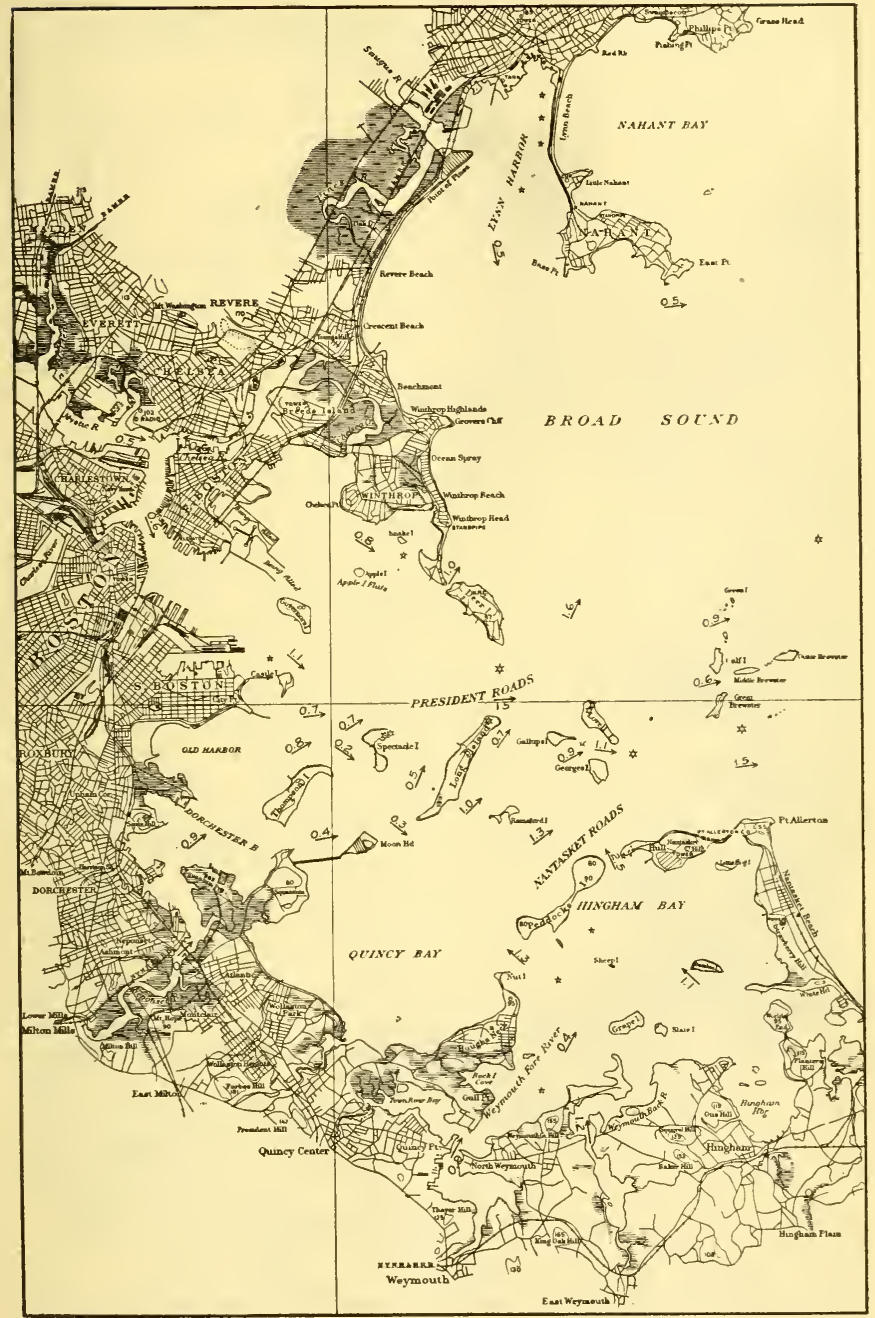

FIg. 24,-CURRENTS FOUR HOURS AFTER HIGH WATER AT COMMONWEALTH PIER NO. 5 


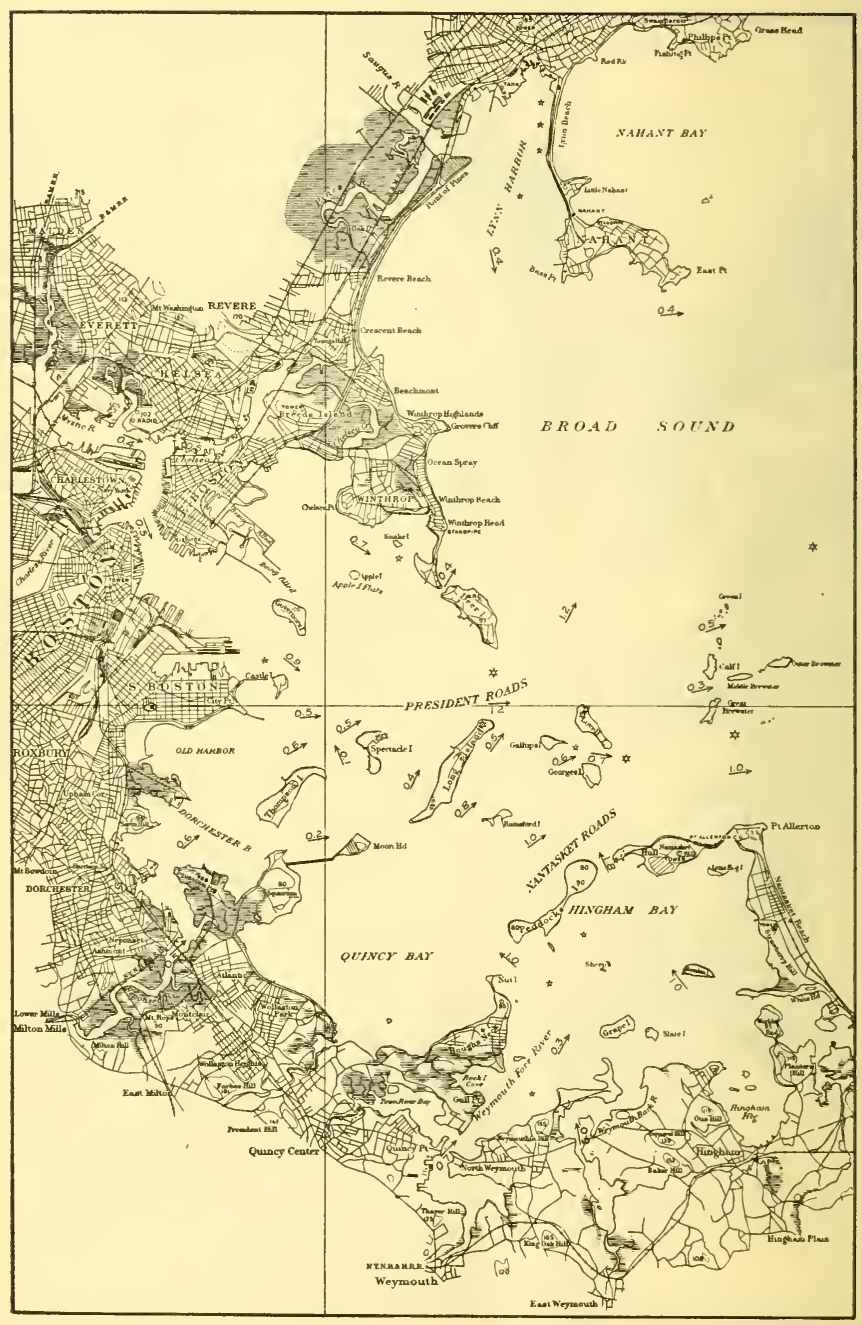

FIg. 25.-CURRENTS FIVE HOURS AFTER HIGH WATER AT COMMONWEALTH PIER NO. 5 


\section{TIDAL DATUMS}

Height datums.-A height datum is a horizontal plane or level surface from which elevations are reckoned. Height datums may be adopted either for local or general use. For local use in a limited area the datum may be taken as any horizontal plane, either selected arbitrarily or derived from some tide plane. For general use over large areas a datum must follow the curvature of the earth, and the best and most universally accepted datum is one based on the mean level of the sea.

Mean sea level.-Mean sea level has been defined as the plane about which the tide oscillates or as the surface which the sea would assume when undisturbed by the rise and fall of the tide. The plane thus defined is the ideal datum which is sought, but the mean sea level obtained from a limited series of tide observations must be considered only as an approximation to the ideal datum.

For practical purposes mean sea level is determined independently at a number of primary tide stations, and in the adjustment of a level net over a large area it is assumed that these various local determinations are in the same level surface. Whether this assumption is strictly true is beyond the scope of this work, but it serves for all practical engineering purposes.

The mean sea level in any locality is obtained by taking the average of the hourly heights of the sea over a considerable period of time and, in some cases, by correcting the result by a comparison with simultaneous observations at another station where the datum has been determined from a longer series of observations. Mean sea level thus obtained will depend to some extent upon the particular observations used in the determinations, and small changes may be expected as additional observations become available and are included in the calculations.

Sea-level datum.-For engineering work the fixedness of a datum is of more importance than a precise agreement with a theoretical definition. For this reason there should be a distinction between the sea level which may have been adopted as a datum for engineering work and the best-known mean sea level which may be determined from time to time from all observations available. The sea-level datum anopted for Boston in connection with the precise leveling of 1923 was derived from the hourly heights of the sea at Commonwealth Pier No. 5, covering a period of two years beginning August 1, 1921 , the results being corrected by a comparison with those obtained from simultaneous observations at Portland, Me., the corresponding datum at the latter place being based upon 11 years of observations.

This sea-level datum is defined as being 13.304 feet below benchmark 7 in the vicinity of the tide station. Through the first-order leveling of 1923 this datum was referred to many other bench marks in Boston and vicinity.

Boston low-water datum.-For some purposes a low-water datum is more convenient than the sea-level datum. Soundings on charts for mariners and the predicted heights of the tide in published tide tables are usually referred to a low-water datum. Likewise much engineering work is referred to low-water datums.

On the Atlantic coast of the United States the mean of all low waters, called mean low water, is usually sought as the datum. 
Unlike mean sea level, mean low water as determined in different localities is not even approximately in the same level surface but varies with the range of tide, and for this reason it is not adapted to leveling operations over large areas. Even in a small area there will be slight differences in mean low water from point to point; for example, mean low water as determined at the navy yard is 0.07 foot lower than the mean low water at Commonwealth Pier No. 5 in South Boston. For practical purposes, however, a low-water datum may be adopted which will approximately represent the mean low water over a limited area.

For Boston Harbor such a datum has been selected and designated as the "Boston low-water datum." This datum is defined as being 14.69 feet below bench mark 1 on the old dry dock at the navy yard in Charlestown. It was established by the Coast Survey many years ago from observations at the navy yard and has since been used by the United States Army Engineers and others. This datum is 0.04 foot above the best-determined mean low water at the navy yard and 0.03 foot below the best-determined mean low water at Commonwealth Pier No. 5 for all observations available at this time. Because of long usage and close agreement with the later results from many years of observations, the continued use of this Boston low-water datum is very desirable.

Boston city base.-The Boston city base is a datum which has been used by the city of Boston for many years. According to the report of the city engineer of Boston for the year 1904, it is 15.11 feet below the "new" bench mark on the coping of the old dry dock, which is bench mark 2 of the Coast and Geodetic Survey. The elevation relative to bench mark 1 on the coping at the entrance to the dry dock is also given in the same report, but bench mark 2 is the basic bench mark for the Boston city levels.

Navy-yard datum.-The datum used by the Navy Department for work in the vicinity of the navy yard at Charlestown has been defined as a plane 114.54 feet below "Navy-Yard Bench Mark 1," which is bench mark 2 of the Coast and Geodetic Survey.

Summary of datums. - The relations of these datums to the sealevel datum as determined by the leveling of 1923 are as follows:

Sea-level datum (13.304 feet below B. M. 7) 00

Boston low-water datum (14.69 feet below B. M. 1)

Boston city base (15.11 feet below B. M. 2)

Navy-yard datum (114.54 feet below B. M. 2)

\section{BENCH MARKS}

A bench mark is a definite point on a more or less permanent object used as a reference for elevations. The standard bench mark used by the Coast and Geodetic Survey is a brass disk $31 / 2$ inches in diameter containing the inscription "U. S. COAST \& GEODETIC SURVEY BENCH MARK," together with other information. Other well-defined points are also used as bench marks. Through bench marks tidal datums determined from observations are preserved for the future use of the engineer.

The following is a list of the several groups of bench marks around Boston Harbor which are described in this volume: 


Boston Light, Little Brewster
Island
Lovells Island,
Georges Island
Chelsea Creek Entrance
Boston (Charlestown)
Boston (central portion)
South Boston

\begin{tabular}{r|} 
Page \\
43 \\
43 \\
44 \\
44 \\
44 \\
45 \\
46
\end{tabular}

Cambridge_...

Brookline

Neponset River Railroad Bridge.- 47

Nut Island.................. 48

Weymouth Fore River Bridge

Crow Point, Hingham Harbor Entrance................. 49

The elevations of the bench mark are referred to the principal tidal datums. Many of them have been connected directly by spirit levels with the basic bench marks used in defining the datums, and others are connected with the datums through simultaneous water levels. The method used in referring the bench marks to the datums is indicated at the beginning of each group of marks.

\section{BOSTON LIGHT, LITTLE BREWSTER ISLAND}

The following bench marks have been referred to the Boston standard datums, through the primary tide station at Commonwealth Pier No. 5, by simultaneous water levels covering the period June 9 to July 21, 1921; the references to the local mean low water are based upon the relations established through the several series of observations at Boston Light:

Bench mark 1 (established in 1860) is the center of a circle cut on top of a ledge of stone and marked thus "C $\odot$ S." It is about 340 feet westerly from the lighthouse and 15 feet southeast of the southeast corner of a boathouse (new in 1899). Elevation, 20.77 feet above sea-level datum; 25.64 feet above Boston low-water datum; 25.30 feet above local mean low water.

Bench mark 3 (established by United States Engineers) is the center of a cross cut on a granite post on the western mound of the island. It bears the U. S. E.

inscription $\bigoplus_{1885}$. Elevation, 20.60 feet above sea-level datum; 25.47 feet above Boston low-water datum; 25.13 feet above local mean low water.

Bench mark 4 (established in 1899) is the top of an eyebolt, without a ring, which is set in the rock westerly from bench mark 3 and is 15 feet north of the northeast corner of the boathouse. Elevation, 15.22 feet above sea-level datum; 20.09 feet above Boston low-water datum; 19.75 feet above local mean low water.

Bench mark 5 (established in 1899) is the top of an eyebolt, containing a large ring, which is set in a rock near and northerly from bench mark 4 . Elevation, 13.69 feet above sea-level datum; 18.56 feet above Boston low-water datum; 18.22 feet above local mean low water.

Bench mark 8 (established in 1916) is a standard Coast and Geodetic Survey bench mark set vertically in ledge in front of keeper's house and near it. Elevation, 21.05 feet above sea-level datum; 25.92 feet above Boston low-water datum; 25.58 feet above local mean low water.

Bench mark 9 (established in 1926) is a standard Coast and Geodetic Survey bench mark cemented in the rock 20 feet from the keeper's house toward the lighthouse. It is stamped "9/1926." Elevation, 18.64 feet above sea-level datum; 23.51 feet above Boston low-water datum; 23.17 feet above local mean low water.

Bench mark 10 (established in 1926) is a standard Coast and Geodetic Survey bench mark cemented into the rock on the point making out northwest from the keeper's house. It is stamped "10/1926." Elevation, 11.44 feet above sealevel datum; 16.31 feet above Boston law-water datum; 15.97 feet above local mean low water.

\section{LOVELLS ISLAND}

The following bench mark is referred to the mean low water as adopted by the United States Engineers; the mean low water, as derived from the very short series of observations in 1912 by the Coast 
and Geodetic Survey, is 0.26 foot higher, but on account of the shortness of this series the result is not conclusive:

Bench mark 1 (established by United States Engineers) is the top of a bronze bolt in the concrete in the yard of the Engineer reservation at Lovells Island. It was later reported that a pipe with screw cap had been set over the bench mark to prevent its being disturbed. Elevation, 16.82 feet above United States Engineers low water.

\section{GEORGES ISLAND}

The following bench marks are referred to the mean low water as adopted by United States Engineers:

Bench mark 3 (established by United States Engineers) consists of a lead plug in a large stone on the south side of the sea wall, 36.7 feet from the angle in the wall and 1.25 feet from the outer face of the same. Elevation, 13.49 feet above United States Engineers low water.

Bench mark $5 \mathrm{a}$ (established in 1916) is the top of an iron bolt 66.9 feet north from the southwest corner of the sea wall and 4.15 feet from face of same. Elevation, 12.93 feet above United States Engineers low water.

Bench mark 6 (established in 1906) is top of large flat stone alongside of an iron bolt on west sea wall. It is 33.1 feet north from southwest corner of the wall and 1 foot from the face of same. Elevation, 12.84 feet above United States Engineers low water.

Bench mark 6a (established in 1916) is the top of bolt described under bench mark 6. Elevation, 12.90 feet above United States Engineers low water.

Bench mark 7 (established in 1916) is a standard Coast and Geodetic Survey bench mark set horizontally in the southeast corner of the red brick building at inner end of wharf at Fort Warren. Elevation, 15.25 feet above United States Engineers low water.

\section{CHELSEA CREEK ENTRANCE}

The following bench marks are referred to the Boston standard datums through the primary tide station at Commonwealth Pier No. 5, by a comparison of simultaneous tides consisting of 13 high waters and 14 low waters observed during the period July 24 to July 31, 1926:

Bench mark 1 (established in 1926) is a Coast and Geodetic Survey standard disk, stamped "1/1926," set on top of the west abutment of highway bridge, 2 feet south of south edge of bridge. Elevation, 12.76 feet above sea-level datum; 17.63 feet above Boston low-water datum.

Bench mark 2 (established in 1926) is a Coast and Geodetic Survey standard disk, stamped " $2 / 1926$," set on top of the west abutment of highway bridge, 2 feet north of north edge of bridge. Elevation, 12.89 feet above sea-level datum; 17.76 feet above Boston low-water datum.

Bench mark 3 (established in 1926) is a Coast and Geodetic Survey standard disk, stamped "3/1926," set on top of east abutment of highway bridge, 18 inches south of south edge of bridge. Elevation, 12.84 feet above sea-level datum; 17.71 feet above Boston low-water datum.

\section{BOSTON (CHARLESTOWN)}

The following bench marks are referred directly to the Boston standard datums by spirit-leveling connections:

Bench mark 1, which has been used since the year 1846, is the top of the granite wall at the entrance to the United States Navy Dry Dock No. 1 at Charlestown. The point taken is directly over the inlaid bronze scale at the southerly corner and outside the floating gate of the dock. Originally there was apparently no special identification mark, but in 1916 a reference was made to a rectangle cut in the stone. Elevation, 9.820 feet above sea-level datum; 14.69 feet above Boston low-water datum.

Bench mark 2 (established in 1867 by A. C. Mitchell), often designated as the "new bench mark," is top of facing of United States Navy Dry Dock No. 1 at Charlestown, on the west side and near the head directly over the foot of the long steps. The place is indicated by an arrow cut in the side of the stone. 
This bench mark has also been designated as "Navy Yard B. M. 1," but it should be distinguished from the original bench mark 1 described above. Elevation, 9.455 feet above sea-level datum; 14.33 feet above Boston low-water datum.

Bench mark 3 (established in 1916 by N. H. Heck) is a standard Coast and Geodetic Survey brass disk set horizontally in the granite block at the head of United States Navy Dry Dock No. 2 at Charlestown. Elevation 8.957 feet above sea-level datum; 13.83 feet above Boston low-water datum.

Navy-yard bench mark 8 is at the head of Dry Dock No. 2 in the Charlestown Navy Yard in the top of the masonry about 1 foot north of bellch mark No. 3. A chiseled square. Elevation, 9.485 feet above sea-level datum; 14.35 feet above Boston low-water datum.

Navy-yard bench mark 10 is north of the tennis courts in the Charlestown Navy Yard, in the pier supporting a column on the southeast side of an octagonal building. A chiseled square. Elevation, 13.307 feet above sea-level datum; 18.18 feet above Boston low-water datum.

Navy-yard bench mark 18 is in the Charlestown Navy Yard, at the corner of Second Avenue and Thirteenth Street, in the top of the lower course of masonry at the southwest corner of building 75 . A chiseled square. Elevation, 10.945 feet above sea-level datum; 15.81 feet above Boston low-water datum.

Navy-yard bench mark 19 is in the Charlestown Navy Yard, at the corner of Fifth Avenue and Sixteenth Street, in the top of the lower course of stone at the northeast corner of building 77. A chiseled square. Elevation, 12.979 feet above sea-level datum; 17.85 feet above Boston low-water datum.

Bench mark "Waverly House" is a Boston city bench mark on the right outer corner, facing the building, of the second stone step at the entrance to Waverly House on the City Square. A point on the step. Elevation, 18.140 feet above sea-level datum; 23.01 feet above Boston low-water datum.

Bench mark F2, near Charlestown, is vertically in the center of the west side of the fourth pier from the eastern or Charlestown end of the "Prison Point Bridge," which is a viaduct carrying Prison Point Street over the railroad tracks and connecting East Cambridge and Charlestown. A brass disk. Elevation, 11.575 feet above sea-level datum; 16.44 feet above Boston low-water datum.

\section{BOSTON (CENTRAL PORTION)}

The following bench marks are referred directly to the Boston standard datums by spirit-leveling connections:

Bench mark "Post Office" is a Weather Bureau bench mark on the post-office building at the corner of Milk Street and Post Office Square, in the corner stone at the southeast corner, 1 foot above the sidewalk. Bench mark is a chiseled square. Elevation, 14.587 feet above sea-level datum; 19.46 feet above Boston low-water datum.

Bench mark " 83 South Street" (established by Boston city engineers) is a Boston city bench mark on the lower iron step at 83 South Street. The left outer corner of the step, facing the building. Elevation, 12.785 feet above sealevel datum; 17.66 feet above Boston low-water datum.

Bench mark J2 (established in 1923 by E. B. Roberts) is a Coast and Geodetic Survey standard disk 306 feet south of the south end of the train shed at the Southern Union Station, 213 feet south of signal bridge No. 1; 63 feet north of signal bridge No. $5 ; 41 / 2$ feet east of an easterly approach track; in the top of the stone coping at the south end of the iron railing. Elevation, 19.308 feet above sea-level datum; 24.18 feet above Boston low-water datum.

Bench mark "B. \& A. mileage 0.40 " is on the northwest corner of the end capstone of the retaining wall at mileage 0.40 on the Boston \& Albany Railroad and also on the New York, New Haven \& Hartford Railroad, south of the tracks of the latter railroad. A chiseled square. Elevation, 12.123 feet above sealevel datum; 16.99 feet above Boston low-water datum.

Bench mark "B. \& A. mileage 0.61 " is on the northeast corner of the central pier of the Boston \& Albany Railroad bridge No. 3 at mileage 0.61 . A chiseled square. Elevation, 1.542 feet above sea-level datum; 6.41 feet above Boston low-water datum.

Bench mark H2 (B. \& A. mileage 1.19) is set horizontally in the footing at the south end of the east center pier of the Boston \& Albany Railroad bridge at mileage 1.19, which is the second overhead bridge south of the Trinity Place depot of the Boston \& Albany Railroad. A brass disk. Elevation, 1.371 feet above sea-level datum; 6.24 feet above Boston low-water datum.

$$
\text { 81772-28-4 }
$$


Bench mark "B. \& A. mileage 1.35 " is at mileage 1.35 on the Boston \& Albany Railroad, on the northwest corner of the lower stone step at the baggage-room door of the Huntington Avenue depot. A chiseled square. Elevation, 4.521 feet above sea-level datum; 9.39 feet above Boston low-water datum.

Bench mark "B. \& A. mileage 2.41" is on the northwest corner of the southwest pier of the Boston \& Albany Railroad signal bridge just east of bridge No. 16 at mileage 2.41. A chiseled square. Elevation, 11.417 feet above sea-level datum; 16.29 feet above Boston low-water datum.

Bench mark G2 (B. \& A. mileage 3.13) is at the east end of the center support of Cottage Farm bridge No. 18 carrying Commonwealth Avenue over the Boston \& Albany Railroad tracks at mileage 3.13 , in the east face of the support, $21 / 2$ feet above the ground. A brass disk. Elevation, 11.001 feet above sea-level datum; 15.87 feet above Boston low-water datum.

Bench mark "Van Orden Cottage Farm" (B. \& A. mileage 3.13) is at th east end of the foundation of the north abutment of Cottage Farm bridge No. 18 carrying Commonwealth Avenue over the Boston \& Albany Railroad tracks at mileage 3.13. A chiseled square. Elevation, 10.075 feet above sea-level datum 14.94 feet above Boston low-water datum.

Bench mark "Boston \& Albany Cottage Farm" (B. \& A. mileage 3.13) is on the west wing, south abutment, of Cottage Farm bridge No. 18 carrying Commonwealth Avenue over the Boston \& Albany Railroad tracks at mileage 3.13, in the northwest corner of the lower coping stone. A chiseled square. Elevation, 12.497 feet above sea-level datum; 17.37 feet above Boston low-water datum.

Bench mark "Cottage Farm, Boston City" (B. \& A. mileage 3.13) is in line with the north curb of Commonwealth Avenue and southwest of the Boston \& Albany Railroad tracks, near the northwest end of the top of the abutment of Cottage Farm bridge No. 18 carrying Commonwealth Avenue over the railroad at mileage 3.13. A point on the bridge abutment. Elevation, 27.802 feet above sea-level datum; 32.67 feet above Boston low-water datum.

\section{SOUTH BOSTON}

The following bench marks are referred directly to the Boston standard datums by spirit-leveling connections:

Bench mark 6 (established in 1921) is a Coast and Geodetic Survey standard disk cemented in window sill of fifth window on northerly side of shore end of Commonwealth Pier No. 5, opposite tide staff. Stamped "6/1921." Elevation, 15.15 feet above sea-level datum; 20.02 feet above Boston low-water datum.

Bench mark 7 (established in 1922) is a Coast and Geodetic Survey standard disk cemented in upper surface of water table on side of heating plant opposite Commonwealth Pier No. 5, stamped "7/1922." This has been adopted as the primary bench mark for the tidal series at Commonwealth Pier No. 5 . Elevation, 13.304 feet above sea-level datum; 18.17 feet above Boston low-water datum.

Bench mark 8 (established in 1922) is a Coast and Geodetic Survey standard disk, stamped "8/1922," cemented in stone retaining wall opposite stairway leading down from Summer Street to C Street, and is on ledge just above first landing about 7 feet below the top of wall. Elevation, 24.813 feet above sea-level datum; 29.68 feet above Boston low-water datum.

Bench mark " 481 Summer Street" (established by Boston city engineers) is the outer right-hand corner of granite doorstep, when facing building, of No. 481 Summer Street. Elevation, 21.519 feet above sea-level datum; 26.39 feet above Boston low-water datum.

Bench mark 20, or "dry dock" (established by Commonwealth of Massachusetts), is the top of brass cap on iron rod, 2 inches in diameter, which has its foot in bedrock and extends upward through the concrete backing of the southern wall of the Navy Dry Dock No. 3 in South Boston, nearly to the surface, and is inclosed in a 4-inch iron pipe. A cast-iron cover bears the inscription "Bench Mark-Do not Disturb." "This bench mark was established by the Commonwealth of Massachusetts and is maintained by the Navy Department. Elevation, 10.272 feet above sea-level datum; 15.14 feet above Boston low-water datum.

Bench mark 9 (established in 1922) is a Coast and Geodetic Survey standard disk, stamped " $9 / 1922$," set in water table on the F Street side of No. 416 West Broadway, under third window, $51 \frac{1}{2}$ feet from front of building. In 1922 building was occupied by P.F. Carey Furniture Co. Elevation, 47.480 feet above sea-level datum; 52.35 feet above Boston low-water datum. 
Bench mark 10 (established in 1922) is a Coast and Geodetic Survev standard disk, stamped "10/1922" set in water table about 2 inches above sidewalk on F Street side of No. 423 West Broadway, 45.6 feet from front of building. In 1922 building was occupied by F. W. Woolworth Co. store. Elevation, 44.675 feet above sea-level datum; 49.55 feet above Boston low-water datum.

Bench mark " 481 West Broadway" (established by Boston city engineers) is a Boston city bench mark, on the right buttress of the stone stairway at No. 481 West Broadway. The right outer corner of the buttress, facing the building. Elevation, 59.15 feet above sea-level datum; 64.02 feet above Boston low-water datum.

Bench mark " 82 G Street" (established by Boston city engineers) is a Boston city bench mark on the right buttress, facing the building, at the side of the stairway at No. $82 \mathrm{G}$ Street. The lower outer corner of the buttress. Elevation, 104.183 feet above sea-level datum; 109.05 feet above Boston low-water datum.

Bench mark 11 (established in 1922) is a Coast and Geodetic Survey standard disk, stamped "11/1922," set in north end of fifth marble step inside iron gate and back of north gatepost at entrance to Washington Monument in Thomas Park, Dorchester Heights, South Boston. Elevation, 143.884 feet above sealevel datum; 148.75 feet above Boston low-water datum.

Bench mark 12 (established in 1922) is a Coast and Geodetic Survey standard disk, stamped "12/1922," set in top of step at right of doorway on entering building at north entrance to South Boston High School. Elevation, 111.578 feet above sea-level datum; 116.45 feet above Boston low-water datum.

\section{CAMBRIDGE}

The following bench marks are referred directly to the Boston standard datums by spirit-leveling connections:

Bench mark E2, at East Cambridge, Middlesex County, about 600 feet north of the Boston \& Maine Railroad depot, in the top of the footing at the east end the north abutment of the bridge carrying the Southern Division over the Fitchburg Division, 4 feet east of the east rail and 2 feet above the Fitchburg Division track level. A brass disk. Elevation, 9.16 feet above sea-level datum; 14.03 feet above Boston low-water datum.

Bench mark "Massachusetts Institute of Technology" is in the basement of the Massachusetts Institute of Technology, in the floor in front of the door to room $3-019$, in the concrete cap on a pile driven into the ground and covered by an iron plate in the floor. A brass plug in the concrete cap. Elevation, 5.203 feet above sea-level datum; 10.07 feet above Boston low-water datum.

Bench mark "Cambridge City" is in the top at the west end of the north abutment of Harvard Bridge carrying Massachusetts Avenue over the Charles River, at the street level and on the Charles River Road, 2 feet from the railings on the bridge. A brass plug. Elevation, 14.951 feet above sea-level datum; 19.82 feet above Boston low-water datum.

\section{BROOKLINE}

The following bench marks are referred directly to the Boston standard datums by spirit-leveling connections:

Bench mark Q2 is about 300 feet west of the west end of the Boston and Albany Railroad depot at Brookline, 5 feet south of the south rail, in the center of the south abutment of the Boston \& Albany Railroad bridge No. 1.56, 3 feet above the ground. A brass disk. Elevation, 17.743 feet above sea-level datum; 22.61 feet above Boston low-water datum.

Bench mark "Van Orden St. Marys Street" is at the east end of the north abutment of St. Marys Street Bridge over the Boston \& Albany Railroad tracks, in the top of the second stone. A chiseled square. Elevation, 11.706 feet above sea-level datum; 16.58 feet above Boston low-water datum.

NEPONSET RIVER RAILROAD BRIDGE

The following bench marks are referred to the Boston standard datums through the primary tide station at Commonwealth Pier No. 
5 , by a comparison of simultaneous tides consisting of 13 high waters: and 11 low waters observed during the period July 14 to July 22, 1926 :

Bench mark 1 (established in 1926) is a Coast and Geodetic Survey standard disk, stamped "1/1926," cemented in drill hole flush with the horizontal top surface of the stone bridge pier at the southerly side of the railroad bridge lift span. The mark is about 1 foot from the bridge span on its easterly side. Elevation, 9.14 feet above sea-level datum; 14.01 feet above Boston low-water datum.

Bench mark 2 (established in 1926) is a Coast and Geodetic Survey standard disk, stamped " $2 / 1926$," cemented in drill hole flush with the horizontal top surface in the next stone pier to the south of bench mark 1. Elevation, 9.06. feet above sea-level datum; 13.93 feet above Boston low-water datum.

Bench mark 3 (established in 1926) is a Coast and Geodetic Survey standard disk, stamped " $3 / 1926$," cemented in drill hole flush with the horizontal top surface of stone bridge pier on the southerly side of the railroad bridge, just north of that in which bench mark 1 is located. Elevation, 8.49 feet above sea-level. datum; 13.36 feet above Boston low-water datum.

\section{NUT ISLAND}

The following bench marks are referred to the Boston standard datums through the primary tide station at Commonwealth Pier No. 5 , by a comparison of simultaneous tides consisting of 89 high waters and $\delta S$ low waters observed during the period June 9 to July 27, 1926:

Bench mark 1 (established by the city of Boston) is a stone monument on the westerly side of Nut Island and reported to be easily found. Elevation, 24.55 feet above sea-level datum; 29.42 feet above Boston low-water datum.

Bench mark 2 (established in 1916) is a Coast and Geodetic Survey standard disk set in northeast corner of granite foundation of sewer pumping station. Elevation, 27.11 feet above sea-level datum; 31.95 feet above Boston low-water datum.

Bench mark 3 established in 1916) is a $1 / 2$-inch brass bolt set vertically in granite block of retaining wall just north of shore end of coal pier. Elevation, is.8S feet above sea-level datum; 23.75 feet above Boston low-water datum.

Bench mark 4 (established in 1926) is a Coast and Geodetic Survey standard disk, stamped " 41926 ," cemented in a drill hole in the concrete coping of a sewer manhole about 40 yards northwest from the shore end of the pier. Elevation, 22.03 feet above sea-level datum; 26.90 feet above Boston low-water datum.

Bench mark 5 (established in 1926) is a Coast and Geodetic Survey standard disk, stamped " 51926 ," cemented on top of a granite block on the upper sea wall about 50 yards south from the boathouse. Elevation, 14.37 feet above sea-level datum; 19.24 feet above Boston low-mater datum.

\section{TEYMOCTH FORE RIVER BRIDGE}

The following bench marks are referred to the Boston standard datums through the primary tide station at Commonwealth Pier No. 5 , by a comparison of simultaneous tides consisting of 14 high waters and 14 low waters observed during the period June 17 to. July 14, 1926:

Bench mark 1 (established in 1926) is a Coast and Geodetic Survey standard disk, stamped "1/1926," set flush with the concrete surface of the stair platform. on its southeast corner south of brick building of Edison coaling plant. Elevation, 10.68 feet above sea-level datum; 15.55 feet above Boston low-water datum.

Bench mark 2 (established in 1926) is a Coast and Geodetic Survey standard disk, stamped "2/1926," set flush with the surface of the concrete wharf near the southwest corner, just south of the concrete mooring bitt block. Elevation, 9.77 feet above sea-level datum; 14.64 feet above Boston low-water datum.

Bench mark 3 (established in 1926) is a Coast and Geodetic Survey standard disk, stamped "3/1926," set flush with the surface of the concrete-fence topthat makes out from the extreme easterly side of the wharf running normal to the road. Elevation, 14.40 feet above sea-level datum; 19.27 feet above Boston. low-water datum. 


\section{CROW POINT, HINGHAM HARBOR ENTRANCE}

The following bench marks are referred to the Boston standard datums through the primary tide station at Commonwealth Pier No. 5, by a comparison of simultaneous tides consisting of 37 high waters and 36 low waters observed during the period June 19 to July 8, 1926:

Bench mark 1 (established in 1926) is a Coast and Geodetic Survey standard disk, stamped " $1 / 1926$," cemented in a drill hole on top of stone sea wall northwest from dock and about halfway between dock entrance and shore. Elevation, 9.44 feet above sea-level datum; 14.31 feet above Boston low-water datum.

Bench mark 2 (established in 1926) is a Coast and Geodetic Survey standard disk, stamped "2/1926," cemented in a drill hole on top of stone sea wall on main shore line about 20 feet south of dock entrance at a turn in the wall. Elevation, 9.00 feet above sea level datum; 13.87 feet above Boston low-water datum.

Bench mark 3 (established in 1926) is a Casst and Geodetic Survey standard disk, stamped " $3 / 1926$," cemented in a drill hole on top of stone sea wall on main shore line about 100 yards northwest of dock entrance at a sudden bend in the shore line. Elevation, 9.33 feet above sea-level datum; 14.20 feet above Boston low-water datum.

\section{TABLES}

The following tables give the results which have been obtained from the observational data discussed in the preceding pages. Explanations of the terms used will be found in the text. A list of the tables follows:

1. Mean lunitidal intervals and duration of rise of tide, Boston Navy Yard ...

2. Mean high and low water on original tide scale, Boston Yary Yard.-

3. Mean high and low water referred to sea-level datum, Boston liavy Yard.

4. Mean range of tide, Boston $\mathrm{Yay}$ Yard

5. Monthly extreme high water above sea-level datum, Boston Javy Yard-

Page

6. Monthly extreme low water below sea-level datum, Boston Nary Yard _.

7. Mean tide level on original tide scale, Boston Navy Yard.......

8. Mean tide level referred to sea-level datum, Boston Navy Yard...

9. High-water lunitidal interval, Commonwealth Pier No. 5.......

10. Low-water lunitidal interval, Commonwealth Pier Jo. 5........

11. Duration of rise of tide, Commonwealth Pier No. 5

12. Mean high water on tide staff, Commonwealth Pier 10.5

13. Iean high water abore sea-level datum, Commonwealth Pier 10.5

14. Mean low water on tide staff, Commonwealth Pier No. 5

15. Mean low water below sea-level datum, Commonwealth Pier No. 5--

16. Mean range of tide, Commonwealth Pier No. 5

17. Mean range corrected for longitude of moon's node, Commonmealth Pier No. 5 .

1S. Monthly extreme high water above sea-level datum, Commonwealth Pier Yo. 5 _. _ .

19. Monthly extreme low water below sea-level datum, Commonwealth Pier No. 5 . .

20. Mean tide level on tide staff, Commonwealth Pier No. 5.

21. Mean tide level referred to sea-level datum, Commonwealth Pier

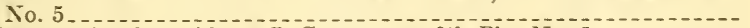

22. Mean sea level on tide staff, Commonwealtt Pier Yo. 5

23. Mean sea level referred to sea-level datum, Commonwealth Pier No. 5 _ _

24. Difference between mean sea level and mean tide level, Commonwealth Pier No. 5 .

25. Summary of time relations, Boston $\mathrm{Xavy}$ Yard and Commonwealth Pier No. 5

26. Summary of ranges and inequalities, Boston Nary Yard and Common-

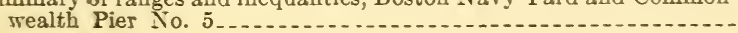


27. Summary of tide planes, Boston Navy Yard and Commonwealth

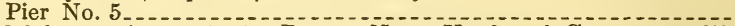

28. Tidal harmonic constants, Boston Navy Yard and Commonwealth Pier No. 5 . .

29. Tidal data, Boston Harbor, $1847-1926 \ldots$

30. Adjusted tidal data, Boston Harbor

31. Current data from observations of C. $\mathrm{H}$. Davis, 1847,1848

32. Current data from observations of H. Mitchell, $1860,1861,1863 \ldots$

33. Current data from observations of committee on Charles River Dam, 1902

34. Current data from observations of $R$. W. Woodworth, 1926

35. Current harmonic constants, stations W1, W16, and W37......

36. Tidal currents, Boston Light Vessel

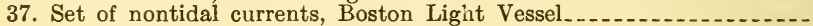

38. Currents due to wind, Boston Light Vessel

39. Current harmonic constants, Boston Light Vessel.

40. Summary of data for surface currents .

41. Condensed current data for selected localities

42. Temperature and density of sea water, Boston Navy Yard, 1863--
43. Temperature and density of sea water, Commonwealth Pier No. 5, 1921-1926

44. Temperature and density of sea water, Boston Harbor, 1926

TABLE 1.-Mean lunitidal intervals and duration of rise of tide, Boston Navy Yard

\begin{tabular}{|c|c|c|c|c|c|c|c|c|c|c|c|}
\hline \multirow{2}{*}{ Year } & \multicolumn{2}{|c|}{$\begin{array}{l}\text { Lunitidal } \\
\text { intervals }\end{array}$} & \multirow{2}{*}{$\begin{array}{c}\text { Dura- } \\
\text { tion } \\
\text { of } \\
\text { rise }\end{array}$} & \multirow{2}{*}{ Year } & \multicolumn{2}{|c|}{$\begin{array}{l}\text { Lunitidal } \\
\text { intervals }\end{array}$} & \multirow{2}{*}{$\begin{array}{l}\text { Dura- } \\
\text { tion } \\
\text { of } \\
\text { rise }\end{array}$} & \multirow{2}{*}{ Year } & \multicolumn{2}{|c|}{$\begin{array}{l}\text { Lunitidal } \\
\text { intervals }\end{array}$} & \multirow{2}{*}{$\begin{array}{l}\text { Dura- } \\
\text { tion } \\
\text { of } \\
\text { rise }\end{array}$} \\
\hline & $\mathbf{H W I}$ & LWI & & & HWI & LWI & & & HWI & LWI & \\
\hline $\begin{array}{l}1847 \\
1848 \\
1849 \\
1850 \\
1851 \\
1852 \\
1853 \\
1854 \\
1855 \\
1856\end{array}$ & $\begin{array}{l}\text { Hours } \\
11.35 \\
11.37 \\
11.40 \\
11.37 \\
11.37 \\
11.37 \\
11.38 \\
11.40 \\
11.40 \\
11.37 \\
\end{array}$ & $\begin{array}{c}\text { Hours } \\
5.20 \\
5.17 \\
5.20 \\
5.17 \\
5.17 \\
5.17 \\
5.18 \\
5.22 \\
5.20 \\
5.17 \\
\end{array}$ & $\begin{array}{c}\text { Hours } \\
6.15 \\
6.20 \\
6.20 \\
6.20 \\
6.20 \\
6.20 \\
6.20 \\
6.18 \\
6.20 \\
6.20 \\
\end{array}$ & $\begin{array}{l}1857 \ldots \ldots \\
1858 \\
1859 \\
1860 \\
1861 \\
1862 \ldots \\
1863 \ldots \\
1864 \\
1865 \\
1866\end{array}$ & $\begin{array}{l}\text { Hours } \\
11.40 \\
11.44 \\
11.40 \\
11.43 \\
11.47 \\
11.47 \\
11.47 \\
11.47 \\
11.53 \\
11.53 \\
\end{array}$ & $\begin{array}{c}\text { Hours } \\
5.20 \\
5.22 \\
5.18 \\
5.23 \\
5.28 \\
5.22 \\
5.25 \\
5.28 \\
5.35 \\
5.33 \\
\end{array}$ & $\begin{array}{c}\text { Hours } \\
6.20 \\
6.22 \\
6.22 \\
6.20 \\
6.19 \\
6.25 \\
6.22 \\
6.19 \\
6.18 \\
6.20 \\
\end{array}$ & $\begin{array}{l}1867 \\
1868 \\
1869 \\
1870 \\
1871 \\
1872 \\
1873 \\
1874 \\
1875 \\
1876\end{array}$ & $\begin{array}{l}\text { Hours } \\
11.48 \\
11.63 \\
11.47 \\
11.50 \\
11.47 \\
11.47 \\
11.35 \\
11.40 \\
11.52 \\
11.48 \\
\end{array}$ & $\begin{array}{c}\text { Hours } \\
5.28 \\
5.25 \\
5.30 \\
5.28 \\
5.22 \\
5.32 \\
5.22 \\
5.25 \\
5.25 \\
5.17 \\
\end{array}$ & $\begin{array}{r}\text { Hours } \\
6.20 \\
6.38 \\
6.17 \\
6.22 \\
6.25 \\
6.15 \\
6.13 \\
6.15 \\
6.27 \\
6.31 \\
\end{array}$ \\
\hline Means...- & $\overline{11.38}$ & 5.19 & 6.19 & Means.. & $\overline{11.46}$ & 5.25 & 6.21 & Means.. & 11.48 & 5.25 & 6.23 \\
\hline
\end{tabular}

1 Records for year incomplete; see note 1, Table 2.

Mean hlgh-water lunitidal interval for entire series.......................................... $=11.44$ hours Mean low-water lunitidal interval for entire series

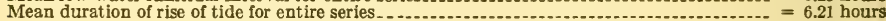

TABLE 2.-Mean high and low water on original tide scale, Boston Navy Yard

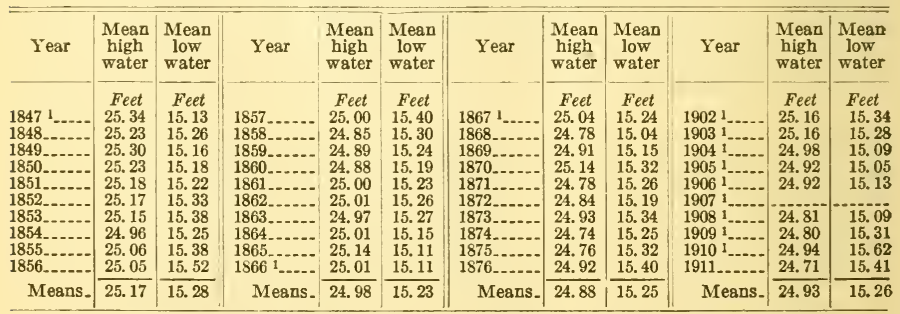

1 Records for year incomplete, the following months being represented: 1847, June to December; 1866 , January to September; 1867 , August to December; 1902, February to December; 1903, January to August, October to November; 1904 , July to December; 1905, January, April to December; 1906, January to August; 1908, January, April to November; 1909, March to December; 1910, March to December.

The above heights are referred to the original tide scale on Dry Dock No. 1 at the navy yard.

Mean high water from entire series..................................... 24.99 feet on original tide scale

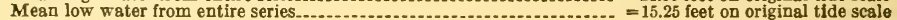


TABLE 3.-Mean high and low water referred to sea-level datum, Boston Navy Yard

\begin{tabular}{|c|c|c|c|c|c|c|c|c|c|c|c|}
\hline Year & $\begin{array}{c}\text { Mean } \\
\text { bigh } \\
\text { water }\end{array}$ & $\begin{array}{c}\text { Mean } \\
\text { low } \\
\text { water }\end{array}$ & Year & $\begin{array}{l}\text { Mean } \\
\text { high } \\
\text { water }\end{array}$ & $\begin{array}{l}\text { Mean } \\
\text { low } \\
\text { water }\end{array}$ & Year & $\begin{array}{c}\text { Mean } \\
\text { high } \\
\text { water }\end{array}$ & $\begin{array}{c}\text { Mean } \\
\text { low } \\
\text { water }\end{array}$ & Year & $\begin{array}{l}\text { Mean } \\
\text { high } \\
\text { water }\end{array}$ & $\begin{array}{c}\text { Mean } \\
\text { low } \\
\text { water }\end{array}$ \\
\hline $\begin{array}{l}1847 \\
1848 \\
1849 \\
1850 \ldots \\
1851 \ldots \ldots \\
1852 \ldots \ldots \\
1853 \ldots \ldots \\
1854 \\
1855 \\
1856 \ldots \ldots\end{array}$ & $\begin{array}{l}\text { Feet } \\
5.16 \\
5.05 \\
5.12 \\
5.05 \\
5.00 \\
4.99 \\
4.97 \\
4.78 \\
4.88 \\
4.87\end{array}$ & $\begin{array}{r}\text { Feet } \\
-5.05 \\
-4.92 \\
-5.02 \\
-5.00 \\
-4.96 \\
-4.85 \\
-4.80 \\
-4.93 \\
-4.80 \\
-4.66\end{array}$ & $\begin{array}{l}1857 \ldots \\
1858 \\
1859 \\
1860 \ldots \\
1861 \ldots \ldots \\
1862 \ldots \ldots \\
1863 \ldots \\
1864 \\
1865 \\
1866 \ldots \ldots\end{array}$ & $\begin{array}{l}\text { Feet } \\
4.82 \\
4.67 \\
4.71 \\
4.70 \\
4.82 \\
4.83 \\
4.79 \\
4.83 \\
4.96 \\
4.83\end{array}$ & $\begin{array}{r}\text { Feet } \\
-4.78 \\
-4.88 \\
-4.94 \\
-4.99 \\
-4.95 \\
-4.92 \\
-4.91 \\
-5.03 \\
-5.07 \\
-5.07\end{array}$ & $\begin{array}{l}1867 \\
1868 \\
1869 \\
1870 \ldots \ldots \\
1871 \\
1872 \ldots \ldots \\
1873 \ldots \ldots \\
1874 \ldots \\
1875 \ldots \ldots \\
1876 \ldots \ldots\end{array}$ & $\begin{array}{l}\text { Feet } \\
4.86 \\
4.60 \\
4.73 \\
4.96 \\
4.60 \\
4.66 \\
4.75 \\
4.56 \\
4.58 \\
4.74\end{array}$ & $\begin{array}{r}\text { Feet } \\
-4.94 \\
-5.14 \\
-5.03 \\
-4.86 \\
-4.92 \\
-4.99 \\
-4.84 \\
-4.93 \\
-4.86 \\
-4.78\end{array}$ & 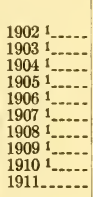 & $\begin{array}{c}\text { Feet } \\
4.98 \\
4.98 \\
4.80 \\
4.74 \\
4.74 \\
-4.63 \\
4.62 \\
4.76 \\
4.53\end{array}$ & $\begin{array}{l}\text { Feet } \\
-4.84 \\
-4.90 \\
-5.09 \\
-5.13 \\
-5.05 \\
--5.09 \\
-4.87 \\
-4.56 \\
-4.77\end{array}$ \\
\hline Means. & 4. 99 & -4.90 & Means. & 4.80 & -4.95 & Means. & 4. 70 & -4.93 & Means_ & 4.75 & -4.92 \\
\hline
\end{tabular}

1 Records for year incomplete; see note 1, Table 2.

Above table is derived by referring the values in Table 2 to the sea-level datum defined on p. 41.

Mean high water from entire series.............. Mean low water from entire series................. Mean high water (corrected for longitude of moon's node)............$=4.80$ feet above sea-level datum Mean low water (corrected for longitude of moon's node) $\ldots . . . . . . . . . . .=4.91$ feet below sea-level datum

TABLE 4.-Mean range of tide, Boston Navy Yard

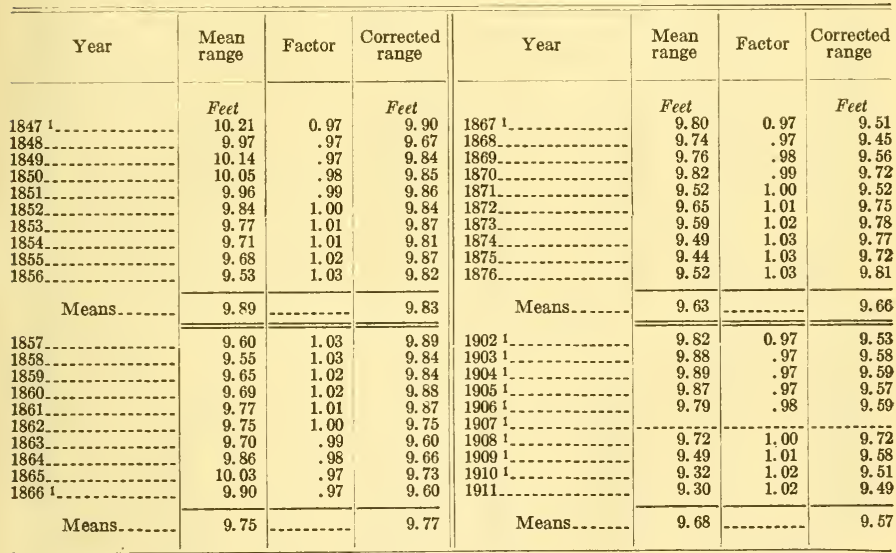

1 Records for year incomplete; see note 1, Table 2.

Mean range of tide from entire series.

Corrected mean range from entire series

The first column following the year contains the mean range of tide as directly obtained from the observa. tions; in the next column are given the factors for correcting for the longitude of the moon's node; and in the last column the mean range as corrected by this factor. 
TABLE 5.-Monthly extreme high water above sea-level datum, Boston Navy Yard

\begin{tabular}{|c|c|c|c|c|c|c|c|}
\hline Date & Height & Date & Height & Date & Height & Date & Height \\
\hline 1847: & Feet & 1852: & Feet & 1857: & Feet & 1862: & Feet \\
\hline June 13 & 6.7 & Jan. 6.- & 6.7 & Jan. 11. & 7.2 & Jan. 1 & 7.6 \\
\hline $\begin{array}{l}\text { July } 31 . \\
\text { Aug. } 26 .\end{array}$ & $\begin{array}{l}6.6 \\
6.7\end{array}$ & & $\begin{array}{l}6.7 \\
6.6\end{array}$ & Feb. 25. & 6.0 & Feb. 20 & \\
\hline $\begin{array}{l}\text { Aug. } 26 \text { - } \\
\text { Sept. } 26\end{array}$ & $\begin{array}{l}6.7 \\
7.7\end{array}$ & $\begin{array}{l}\text { Mar. } 6,18 \\
\text { Apr. } 6 \ldots \ldots\end{array}$ & $\begin{array}{l}6.6 \\
8.0\end{array}$ & $\begin{array}{l}\text { Mar. 27. } \\
\text { Apr. 27. }\end{array}$ & $\begin{array}{l}6.8 \\
7.1\end{array}$ & $\begin{array}{l}\text { Mar. } 16 \\
\text { Apr. } 14\end{array}$ & $\begin{array}{l}7.8 \\
6.3\end{array}$ \\
\hline Oct. 25 & 7.3 & May $2 \ldots$ & 7. 3 & May 23. & 6.5 & May 13 . & $\begin{array}{l}0.0 \\
7.1\end{array}$ \\
\hline $\begin{array}{l}\text { Nov. } 24-\ldots- \\
\text { Dec, } 22\end{array}$ & 6. 9 & $\begin{array}{l}\text { June } 2 \ldots \\
\text { July } 29\end{array}$ & 6. 8 & Jun & 6.3 & June 12 & 7.4 \\
\hline Dec. $22 \ldots$ & & $\begin{array}{l}\text { July } 29 . \\
\text { Aug. 18... }\end{array}$ & $\begin{array}{l}6.3 \\
6.4\end{array}$ & $\begin{array}{l}\text { July } 24 \ldots \\
\text { Aug. } 18 \ldots\end{array}$ & $\begin{array}{l}6.5 \\
6.1\end{array}$ & $\begin{array}{l}\text { July } 9- \\
\text { Aug. } 9\end{array}$ & $\begin{array}{l}7.2 \\
6.9\end{array}$ \\
\hline Highest_... & 7.7 & Sept. $16_{-}$ & 6.9 & Sept. 7 & 5.9 & Sept. 25 & 6.1 \\
\hline ge...- & 7.06 & Oct. 15 & 7. 5 & Oct. 6 -- & 6.8 & Oct. 27 & 7.0 \\
\hline 1848: & & Dec. 11 & $\begin{array}{l}7.7 \\
8.1\end{array}$ & $\begin{array}{l}\text { Nov. } 3 \text {-- } \\
\text { Dec. } 31 \text {. }\end{array}$ & $\begin{array}{l}7.2 \\
8.3\end{array}$ & $\begin{array}{l}\text { Nov. } 7,21,22 \\
\text { Dec. } 23\end{array}$ & $\begin{array}{l}7.1 \\
6.8\end{array}$ \\
\hline $\begin{array}{l}\text { Jan. } 9 \\
\text { Feb. } 5\end{array}$ & $\begin{array}{l}6.4 \\
8.0\end{array}$ & Highest... & 8.1 & Highest & 8.3 & High & \\
\hline Mar. 10 & 6.8 & Ave & 7.08 & $A v$ & 6.72 & Average & 7.01 \\
\hline $\begin{array}{l}\text { Apr. } 6 \\
\text { May } 3 .\end{array}$ & $\begin{array}{l}6.3 \\
7.2\end{array}$ & $\begin{array}{l}\text { 1853: } \\
\text { Jan. } 4\end{array}$ & 7.8 & $\begin{array}{l}\text { 1858: } \\
\text { Jan. } 29\end{array}$ & & & \\
\hline June & 7.1 & Feb. 23 & 6.9 & $\begin{array}{l}\text { Jan. } 29 \\
\text { Feb. } 26,2\end{array}$ & $\begin{array}{l}7.6 \\
5.9\end{array}$ & 1863: & \\
\hline July 3 & 6.8 & Mar. 27 & 6.7 & Mar. I & $\begin{array}{l}0.9 \\
6.1\end{array}$ & Feb. 19 & $\begin{array}{l}7.3 \\
6.5\end{array}$ \\
\hline Aug. 17. & 6.7 & Apr. $26 .-$ & 6.9 & Apr. 15 & 7.1 & Mar. 8 & 6.3 \\
\hline Sept. 1 & 6.8 & May 24. & 7.4 & 15 . & 6.7 & Apr. 5. & 6.9 \\
\hline Oct. 14, & 7.3 & $\begin{array}{l}\text { June } 23 . \\
\text { July } 20\end{array}$ & $\begin{array}{l}7.3 \\
6.8\end{array}$ & Ju & 7. 2 & May 6. & 6.7 \\
\hline Nov. $12,13 \ldots$ & 7.2 & $\begin{array}{l}\text { July } 20 \\
\text { Aug, } 18,20\end{array}$ & $\begin{array}{l}6.8 \\
6.7\end{array}$ & Ju & 7. 2 & $\mathrm{Ju}$ & 6.9 \\
\hline Dec. 10 - & 7.6 & $\begin{array}{l}\text { Aug. } 18,20 \ldots \\
\text { Sept. } 15\end{array}$ & $\begin{array}{l}6.7 \\
6.7\end{array}$ & Aug. 9 & 7.0 & July 1... & 7.0 \\
\hline Highest...- & 8.0 & Oct. 5 & 6.2 & Oct. 25 -. & $\begin{array}{l}0.1 \\
7.9\end{array}$ & 25 & $\begin{array}{l}7.0 \\
6.3\end{array}$ \\
\hline Ave & 7. 02 & Nov. 30 & 7.1 & Nov .23_ & 8.5 & Oct. 26 & $\begin{array}{l}0.3 \\
6.5\end{array}$ \\
\hline & & Dec. 29 & 8.9 & Dec. 21 . & 8.1 & Nov. 14 & 6.7 \\
\hline 1849: & 7. 5 & $\begin{array}{l}\text { High } \\
\text { Aver }\end{array}$ & $\begin{array}{l}8.9 \\
7.12\end{array}$ & Highe & 8.5 & Dec. 13 & 7.2 \\
\hline $\begin{array}{l}\text { Feb. } 7- \\
\text { Mar. } 28\end{array}$ & 7.1 & 1854: & & & & Highe & 7.3 \\
\hline Apr. 25 & $\begin{array}{l}.00 \\
6.1\end{array}$ & $\begin{array}{l}\text { 1854: } \\
\text { Jan. } 1 . .\end{array}$ & 6.9 & $\begin{array}{l}\text { 18b9: } \\
\text { Jan. } 4\end{array}$ & 7.3 & A verag & 6.78 \\
\hline May & 6.4 & Feb. $26 \ldots$ & 6.4 & 18 & 7.1 & 1864: & \\
\hline June & 7. 3 & Mar. 31. & 6.0 & M & 6. 3 & Jan. 13 & 5.7 \\
\hline Jul & 7. & Apr & 6. & & 6. & $\mathrm{~F}$ & 6.3 \\
\hline Aug. 17 & 6.9 & May 15. & 6. & M & 6. & M & 8.1 \\
\hline Sept & 6.4 & $\mathrm{JuI}$ & 7. & & 6. & & 7.1 \\
\hline Oct. 7 & 7.7 & Jul & 7. & 2,30 & 7. & & 6.8 \\
\hline Nov. 30 & 6.9 & Aug. 8 & 7. & $\begin{array}{l}\mathrm{A} z \\
\mathrm{Se}\end{array}$ & $\begin{array}{l}7 . \\
6 .\end{array}$ & $\mathrm{Ju}$ & 6. 6 \\
\hline Dec. 3 & 7.8 & $\begin{array}{l}\text { Sept. } 6 \ldots \\
\text { Oct. } 25 \ldots\end{array}$ & $\begin{array}{l}6.9 \\
6.5\end{array}$ & $\begin{array}{l}\text { Sept. } 25,27 \\
\text { Oct. } 25,27 \text {. }\end{array}$ & $\begin{array}{l}6.6 \\
6.5\end{array}$ & $\begin{array}{l}\text { July } 22 \\
\text { Aug. } 17 .\end{array}$ & $\begin{array}{l}7.1 \\
6.7\end{array}$ \\
\hline High & 7. 8 & Nov. 22 & 6.8 & Nov. $22 \ldots$ & 7.1 & Sept. 15 & 6.6 \\
\hline Ave & $0:$ & Dec. $3 .$. & 8.8 & Dec. 11 & 6.7 & Oct. 14 & 6.9 \\
\hline 1850: & & $\begin{array}{l}\text { Highest... } \\
\text { A verage..- }\end{array}$ & $\begin{array}{l}8.8 \\
6.90\end{array}$ & $\begin{array}{l}\text { Highe } \\
\text { Avera }\end{array}$ & $\begin{array}{l}7.3 \\
6.73\end{array}$ & $\begin{array}{l}\text { Nov. } 13 \\
\text { Dec. } 29\end{array}$ & $\begin{array}{l}7.4 \\
6.6\end{array}$ \\
\hline $\begin{array}{l}\text { Jan. 27, } \\
\text { Feb. 25. }\end{array}$ & $\begin{array}{l}7.5 \\
7.1\end{array}$ & 1855: & & 1860: & & & \\
\hline Mar. 1 & 6.9 & Jan. 19 & 8. 1 & Jan. 10 & 6.9 & $\begin{array}{l}\text { High } \\
\text { Aver }\end{array}$ & $\begin{array}{l}8.1 \\
6.82\end{array}$ \\
\hline Apr. 14 & 6. 7 & Feb. 16 & 7.9 & & 6.9 & & \\
\hline May & 6 & Mar. & 7. & & 7. & 1865: & \\
\hline June $1:$ & 6. & Ap & 6. & Al & 6. & $\mathbf{J a}$ & 6.0 \\
\hline $\begin{array}{l}\text { July } 9 \\
\text { Aug. } 8\end{array}$ & & $\mathrm{Ma}$ & & & & & 6.9 \\
\hline $\begin{array}{l}\text { Aug. } 8,10 \\
\text { Sept. } 8\end{array}$ & $\begin{array}{l}7.1 \\
7.2\end{array}$ & Jur & 6. & Ju & . & M & 6.9 \\
\hline $\begin{array}{l}\text { Sept. } 8 \\
\text { Oct. } 6\end{array}$ & $\begin{array}{l}7.2 \\
6.6\end{array}$ & Jul & & $\mathrm{Ju}$ & 6. & & 7.2 \\
\hline $\begin{array}{l}\text { Oct } \\
\text { No }\end{array}$ & $\begin{array}{l}6.6 \\
6.7\end{array}$ & $9-\ldots$ & 7. & & 6. & & 7.1 \\
\hline $\begin{array}{l}\text { Nov. } 21 \text {. } \\
\text { Dec. } 23 .\end{array}$ & $\begin{array}{l}6.7 \\
8.0\end{array}$ & Sept. 25, 27 $\ldots$ & 7. & Se & 0. & & 6.4 \\
\hline Dec. 23 & & Oct. 24 & 6. 8 & Oet. 15 & 6.9 & July $8,21 \ldots$ & $\begin{array}{l}5.9 \\
6.0\end{array}$ \\
\hline Hig & 8. & Dec. 9 & 6.4 & $\begin{array}{l}\text { Nov. } 11 . . \\
\text { Dec. } 12 . .\end{array}$ & 6.6 & & $\begin{array}{l}\text { b. } \\
6.4\end{array}$ \\
\hline$A \nabla$ & & Highest_-_--_ & 8.1 & High & 7. & Oc & 7.0 \\
\hline 1851: & & A verag & 7. 02 & A verag & 6.83 & $\begin{array}{l}\text { Nov. } 30 \\
\text { Dec. } 1 .\end{array}$ & 7.4 \\
\hline $\begin{array}{l}\text { Jan. } 17 \\
\text { Feb. } 16\end{array}$ & 7. 5 & 1856: & & 1861: & & Higl & 7.7 \\
\hline Mar. 18 & $\begin{array}{l}6.7 \\
9.0\end{array}$ & $8 \ldots$ & $\begin{array}{l}8.2 \\
6.9\end{array}$ & Feb. 28. & $\begin{array}{l}6.9 \\
6.3\end{array}$ & A verage & 6.74 \\
\hline Apr. 16 & 10. 1 & Mar. $6,7,8 \ldots$ & 6. 7 & Mar. 28 & 6. & 1866: & \\
\hline $\mathrm{Ma}$ & 6. & Al & 7. & 25,27 & 7. & Jan. & 6.7 \\
\hline & 6. & May & 6. & May 26 & 7. & $\mathrm{Fe}$ & 6.2 \\
\hline July 1 . & 6.9 & Jun & 6. & $\mathrm{Ju}$ & 6. & $\mathrm{M}$ & 6.3 \\
\hline $\mathrm{Au}$ & 6. & & 6. & $20_{-}$ & 6. & Apr. 17 & 6.1 \\
\hline & 7. 0 & $16 \ldots$ & 7. 2 & 13. & 6. & May 14 & 7.3 \\
\hline Oct. 26 & 7. 2 & Sept. 16.. & 6.9 & Sep & 6. & Jur & 7.2 \\
\hline Nov. 21 & 8.2 & Oet. 15 & 6.5 & & 7. & July 12 & 7.0 \\
\hline Dec. 24 & 6.4 & Nov. $12,13 \ldots$ & $\begin{array}{l}6.8 \\
7.0\end{array}$ & Nov. 3 & 8.7 & Aug. 9 & 6.5 \\
\hline $\mathrm{Hi}$ & 10.1 & Dec. $14 \ldots . .$. & 7.0 & Dec. $31 \ldots$ & 7.1 & Sept. 26 & 6.3 \\
\hline & 7. & $\begin{array}{l}\text { Highest... } \\
\text { Average. }\end{array}$ & $\begin{array}{l}8.2 \\
6.93\end{array}$ & $\begin{array}{l}\text { Highest..... } \\
\text { Average.... }\end{array}$ & $\begin{array}{l}8.7 \\
7.00\end{array}$ & $\begin{array}{l}\text { Highest_.... } \\
\text { A verage }\end{array}$ & $\begin{array}{l}7.3 \\
6.62\end{array}$ \\
\hline
\end{tabular}


TABLE 5.-Monthly extreme high water above sea-level datum, Boston Navy YardContinued

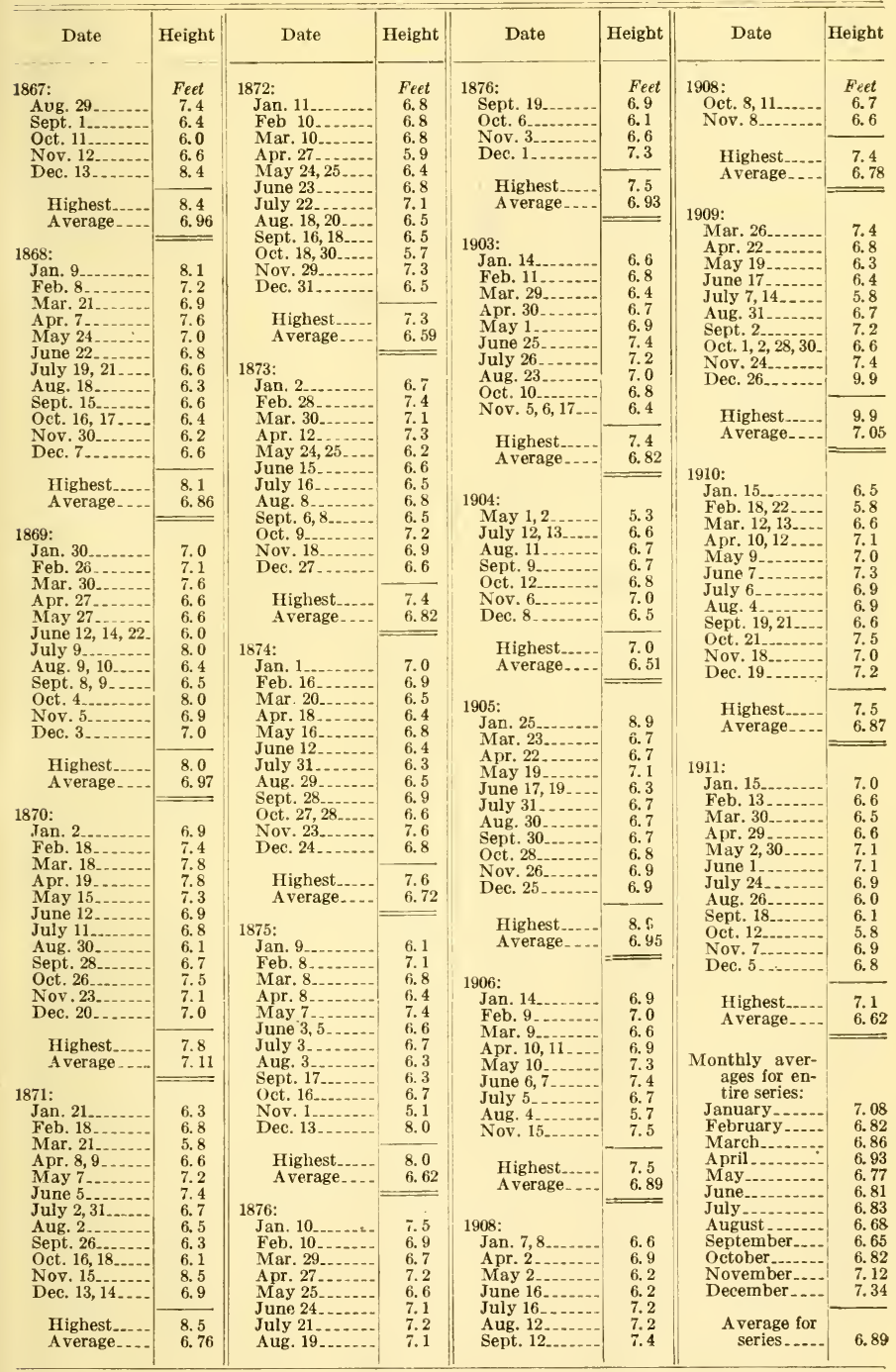

Highest tide of these observations was 10.1 feet above the sea-level datum and occurred on Apr. 16, 1851, during a severe storm which destroyed the Minots Ledge Lighthouse.

The heights in the above table are referred to the sea-level datum defined on p. 41. 
TABLE 6.-Monthly extreme low water below sea-level datum, Boston Navy Yard

\begin{tabular}{|c|c|c|c|c|c|c|c|}
\hline Date & Height & Date & Height & Date & Height & Date & Height \\
\hline 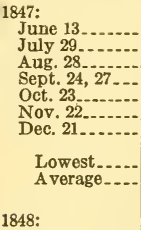 & $\begin{array}{r}\text { Feet } \\
6.6 \\
7.0 \\
7.4 \\
6.6 \\
7.5 \\
7.5 \\
6.7 \\
7.5 \\
7.04 \\
\end{array}$ & 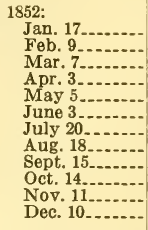 & $\begin{array}{l}\text { Feet } \\
6.6 \\
7.0 \\
7.5 \\
7.0 \\
7.8 \\
6.9 \\
6.9 \\
7.0 \\
6.9 \\
6.9 \\
7.3 \\
6.9 \\
\end{array}$ & $\begin{array}{l}\text { 1857: } \\
\text { Jan. 11...... } \\
\text { Feb. 24 } \\
\text { Mar. } 27 . \ldots \\
\text { Apr. } 27 \\
\text { May } 25 \\
\text { June } 24 \\
\text { July } 24 \\
\text { Aug. } 19 \\
\text { Sept. } 6 \\
\text { Oct. } 5 \\
\text { Nov. } 2 \\
\text { Dec. } 2 \\
\end{array}$ & $\begin{array}{l}\text { Feet } \\
7.1 \\
6.8 \\
7.2 \\
6.8 \\
6.8 \\
6.7 \\
6.1 \\
6.1 \\
6.5 \\
6.7 \\
7.1 \\
7.4 \\
\end{array}$ & 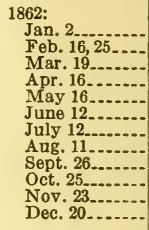 & $\begin{array}{l}\text { Feet } \\
7.7 \\
6.7 \\
7.1 \\
7.8 \\
7.4 \\
6.9 \\
6.8 \\
6.4 \\
6.5 \\
7.3 \\
8.1 \\
7.7 \\
\end{array}$ \\
\hline $\begin{array}{l}\text { Jan. } 9,20 \\
\text { Feb. } 11 \ldots \\
\text { Mar. } 6\end{array}$ & $\begin{array}{l}6.9 \\
6.2 \\
7.9\end{array}$ & Lowe & $\begin{array}{l}7.8 \\
7.06 \\
\end{array}$ & $\begin{array}{l}\text { Lowest } \\
\text { Averag }\end{array}$ & $\begin{array}{l}7.4 \\
6.78 \\
\end{array}$ & $\begin{array}{l}\text { Lowes } \\
\text { A vera }\end{array}$ & $\begin{array}{l}8.1 \\
7.20 \\
\end{array}$ \\
\hline 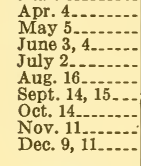 & $\begin{array}{l}7.8 \\
7.1 \\
6.6 \\
6.6 \\
6.6 \\
6.4 \\
7.0 \\
7.5 \\
7.3\end{array}$ & 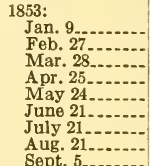 & $\begin{array}{l}6.8 \\
6.6 \\
7.4 \\
7.7 \\
7.4 \\
7.4 \\
6.9 \\
6.0 \\
6.3\end{array}$ & $\begin{array}{l}\text { 1858: } \\
\text { Jan. 1...- } \\
\text { Feb. 27-- } \\
\text { Mar. 19-- } \\
\text { Apr. 16.- } \\
\text { May 14-- } \\
\text { June 12-- } \\
\text { July 11...- } \\
\text { Aug. } 9,10\end{array}$ & $\begin{array}{l}7.3 \\
6.6 \\
6.8 \\
6.9 \\
7.5 \\
7.1 \\
6.9 \\
6.5 \\
6.7\end{array}$ & $\begin{array}{l}\text { 1863: } \\
\text { Jan. 19.- } \\
\text { Feb. 17.- } \\
\text { Mar. 20. } \\
\text { Apr. } 9 .- \\
\text { May 5.- } \\
\text { June 4.- } \\
\text { July 31.- } \\
\text { Aug. 1..- }\end{array}$ & $\begin{array}{l}7.7 \\
7.6 \\
7.2 \\
6.7 \\
6.7 \\
7.0 \\
7.4 \\
7.3\end{array}$ \\
\hline $\begin{array}{l}\text { Lowes } \\
\text { A vera }\end{array}$ & $\begin{array}{l}7.9 \\
6.99\end{array}$ & $\begin{array}{l}\text { Oct. } 4 . . . \\
\text { Nov. } 2 \ldots \\
\text { Dec. } 1 . . .\end{array}$ & $\begin{array}{l}0.3 \\
6.6 \\
7.3 \\
6.5\end{array}$ & $\begin{array}{l}\text { Oct. } 22,23 \\
\text { Nov. } 20 \\
\text { Dec. } 23\end{array}$ & $\begin{array}{l}6.2 \\
6.8 \\
7.4\end{array}$ & $\begin{array}{l}\text { Sept. } 28 . \\
\text { Oct. } 14 \\
\text { Nov. } 11 \\
\text { Dec. } 15\end{array}$ & $\begin{array}{l}6.5 \\
6.0 \\
6.6 \\
7.4 \\
\end{array}$ \\
\hline $\begin{array}{l}\text { 1849: } \\
\text { Jan. 8.... } \\
\text { Feb. } 8 . . \\
\text { Mar. } 26 .\end{array}$ & $\begin{array}{l}7.2 \\
6.8 \\
6.7\end{array}$ & $\begin{array}{l}\text { Lowest } \\
\text { Average } \\
\text { 1854: }\end{array}$ & $\begin{array}{l}7.7 \\
6.91 \\
\end{array}$ & $\begin{array}{l}\text { Lowe } \\
\text { Aver } \\
\text { 1859: }\end{array}$ & $\begin{array}{l}7.5 \\
6.89 \\
\end{array}$ & $\begin{array}{l}\text { Lowes } \\
\text { Avera }\end{array}$ & $\begin{array}{l}7.7 \\
7.01 \\
\end{array}$ \\
\hline $\begin{array}{l}\text { Apr. } 26 . . \\
\text { May } 25 . . \\
\text { June } 22 .- \\
\text { July } 21 .- \\
\text { Aug. } 19 .- \\
\text { Sept. } 17 . . \\
\text { Oct. } 31 .- \\
\text { Nov. } 30 \ldots \\
\text { Dec. } 28 . \\
\end{array}$ & $\begin{array}{l}7.3 \\
7.0 \\
7.2 \\
7.0 \\
6.6 \\
6.4 \\
6.4 \\
6.8 \\
7.1\end{array}$ & 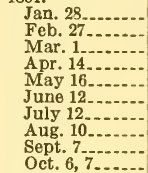 & $\begin{array}{l}7.9 \\
7.7 \\
7.5 \\
6.8 \\
7.0 \\
7.2 \\
7.7 \\
7.1 \\
7.1 \\
6.7\end{array}$ & $\begin{array}{l}\text { Jan. } 20 \\
\text { Feb. } 17 \\
\text { Mar. } 20 \\
\text { Apr. } 17 . \\
\text { May } 5 \\
\text { June } 3 \\
\text { July } 31 \\
\text { Aug. } 1 \\
\text { Sept. } 27 \\
\text { Oct. } 26\end{array}$ & $\begin{array}{l}7.5 \\
7.6 \\
7.2 \\
6.7 \\
6.9 \\
7.1 \\
7.3 \\
7.3 \\
6.7 \\
6.7\end{array}$ & $\begin{array}{l}\text { 1864: } \\
\text { Jan. 9.-. } \\
\text { Feb. 9.- } \\
\text { Mar. } 9 .- \\
\text { Apr. } 7-- \\
\text { May 6..- } \\
\text { June 22- } \\
\text { July 19-. } \\
\text { Aug. 20- } \\
\text { Sept. 17. }\end{array}$ & $\begin{array}{l}7.3 \\
8.1 \\
7.5 \\
7.0 \\
6.7 \\
7.0 \\
7.0 \\
7.5 \\
7.3\end{array}$ \\
\hline $\begin{array}{l}\text { Low } \\
\text { Ave }\end{array}$ & $\begin{array}{l}7.3 \\
6.88 \\
\end{array}$ & $\begin{array}{l}\text { Nov. } 22 . \\
\text { Dec. } 21 . .\end{array}$ & $\begin{array}{l}6.2 \\
6.9\end{array}$ & $\begin{array}{l}\text { Nov. } 13 \\
\text { Dec. } 12 .\end{array}$ & $\begin{array}{l}7.1 \\
6.5\end{array}$ & $\begin{array}{l}\text { Oct. } 17 \\
\text { Nov. } 14 \\
\text { Dec. } 12 .\end{array}$ & $\begin{array}{l}7.3 \\
6.6 \\
7.8\end{array}$ \\
\hline $\begin{array}{l}\text { 1850: } \\
\text { Jan. 27-- } \\
\text { Feb. 27- }\end{array}$ & $\begin{array}{l}6.7 \\
7.2\end{array}$ & $\begin{array}{l}\text { Lowest_- } \\
\text { A verage } \\
\text { 1855: }\end{array}$ & $\begin{array}{l}7.9 \\
7.15\end{array}$ & $\begin{array}{l}\text { Low } \\
\text { Aver } \\
\text { 1860: }\end{array}$ & $\begin{array}{l}7.6 \\
7.05\end{array}$ & $\begin{array}{l}\text { Lowest } \\
\text { Average }\end{array}$ & $\begin{array}{l}8.1 \\
7.26 \\
\end{array}$ \\
\hline $\begin{array}{l}\text { Mar. } \\
\text { Apr. }\end{array}$ & $\begin{array}{l}7.1 \\
7.4\end{array}$ & $\begin{array}{l}\text { Jan. 21 } \\
\text { Feb. 17... }\end{array}$ & $\begin{array}{l}6.3 \\
6.7\end{array}$ & $\begin{array}{l}\text { Jan. } 11 \\
\text { Feb. } 10 .\end{array}$ & $\begin{array}{l}7.3 \\
7.9\end{array}$ & 1865: & \\
\hline $\begin{array}{l}\text { May } \\
\text { Jun }\end{array}$ & $\begin{array}{l}7.2 \\
7.4\end{array}$ & $\begin{array}{l}\text { Mar. } 21 . . \\
\text { Apr. } 17 . .\end{array}$ & $\begin{array}{l}7.6 \\
7.0\end{array}$ & $\begin{array}{l}\text { Mar. } 10 . \\
\text { Apr. } 8 . .\end{array}$ & $\begin{array}{l}7.6 \\
7.5\end{array}$ & Jan & $\begin{array}{l}6.7 \\
7.7\end{array}$ \\
\hline $\mathrm{Jul}$ & $\begin{array}{l}7.2 \\
7.1\end{array}$ & $\begin{array}{l}\text { May } 18 \ldots . . \\
\text { June } 2 \ldots . . .\end{array}$ & $\begin{array}{l}6.3 \\
6.6\end{array}$ & $\begin{array}{l}\text { May } 6 \\
\text { June } 22,24\end{array}$ & $\begin{array}{l}7.0 \\
6.3\end{array}$ & Ap & 7.1 \\
\hline $\begin{array}{l}\text { Sep } \\
\text { Oct. }\end{array}$ & 6.7 & July $31 \ldots$ & 7.1 & July 20 & $\begin{array}{l}6.8 \\
6.8\end{array}$ & & $\begin{array}{l}6.6 \\
6.7\end{array}$ \\
\hline $\begin{array}{l}\text { Oct. } \\
\text { Nov } \\
\text { Dec. }\end{array}$ & $\begin{array}{l}6.6 \\
6.9 \\
6.7\end{array}$ & $\begin{array}{l}\text { Aug. } 30 \ldots \\
\text { Sept. } 26 .- \\
\text { Oct. } 26 . .\end{array}$ & $\begin{array}{l}0.8 \\
6.4 \\
6.7\end{array}$ & $\begin{array}{l}\text { Aug. 18, } 19 \\
\text { Sept. 16.- } \\
\text { Oct. } 15\end{array}$ & $\begin{array}{l}0.8 \\
7.5 \\
7.6\end{array}$ & & $\begin{array}{l}6.6 \\
7.0\end{array}$ \\
\hline Lov & 7. & $\begin{array}{l}\text { Nov. } 24 \text {-. } \\
\text { Dec. } 24 . .\end{array}$ & $\begin{array}{l}7.2 \\
6.5 \\
\end{array}$ & $\begin{array}{l}\text { Nov. } 13 . . \\
\text { Dec. } 14 . .\end{array}$ & $\begin{array}{l}6.5 \\
7.5 \\
\end{array}$ & $\begin{array}{l}\text { Sept. } 6 . \\
\text { Oct. } 7 . . \\
\text { Nov. } 3 .\end{array}$ & $\begin{array}{l}7.1 \\
7.3 \\
7.8\end{array}$ \\
\hline & 7.02 & $\begin{array}{l}\text { Lowest...... } \\
\text { A verage.... }\end{array}$ & $\begin{array}{l}7.6 \\
6.77\end{array}$ & $\begin{array}{l}\text { Lowest. . } \\
\text { Average.. }\end{array}$ & $\begin{array}{l}7.9 \\
7.19\end{array}$ & Dec. 3 & 7.5 \\
\hline $\begin{array}{l}\text { 1851: } \\
\text { Jan. 19... } \\
\text { Feb. 16... }\end{array}$ & $\begin{array}{l}7.5 \\
7.9\end{array}$ & $\begin{array}{l}\text { 1856: } \\
\text { Jan. 11. } \\
\text { Feb. } 6,7\end{array}$ & 6.1 & $\begin{array}{l}\text { 1861: } \\
\text { Jan. } 30,31 \\
\text { Feb. } 25\end{array}$ & 6.6 & $\begin{array}{l}\text { Lov } \\
\text { Ave }\end{array}$ & $\begin{array}{l}7.8 \\
7.13\end{array}$ \\
\hline $\begin{array}{l}\text { Mar. } 20 \\
\text { Apr. } 12,13\end{array}$ & $\begin{array}{l}6.7 \\
6.0\end{array}$ & $\begin{array}{l}\text { Feb. } 6,7 \\
\text { Mar. } 8,9 . \\
\text { Apr. } 6\end{array}$ & $\begin{array}{l}7.0 \\
7.9 \\
7.4\end{array}$ & $\begin{array}{l}\text { Feb. } 25,26 \\
\text { Mar. } 28 \\
\text { Apr. } 26\end{array}$ & $\begin{array}{l}7.6 \\
8.2 \\
7\end{array}$ & $\begin{array}{l}\text { 1866: } \\
\text { Jan. } 1 .\end{array}$ & 7.2 \\
\hline $\begin{array}{l}\text { May } 1 \\
\text { June } 3\end{array}$ & $\begin{array}{l}6.3 \\
6.2\end{array}$ & May & 6.8 & Apr. & 7.2 & $\begin{array}{l}\text { Feb. } 16 . \\
\text { Mar. } 19 .\end{array}$ & $\begin{array}{l}7.8 \\
7.6\end{array}$ \\
\hline $\begin{array}{l}\text { July } 31 . . \\
\text { Aug. } 28 .\end{array}$ & $\begin{array}{l}7.0 \\
7.4\end{array}$ & $\begin{array}{l}\text { June } 3 \\
\text { July } 21 .\end{array}$ & $\begin{array}{l}6.9 \\
6.6\end{array}$ & $\begin{array}{l}\text { June } 22 \\
\text { July } 22,23 .\end{array}$ & $\begin{array}{l}6.7 \\
6.4\end{array}$ & Apr. 18 & 6.8 \\
\hline Sep & 7.1 & $\begin{array}{l}\text { Aug. } 17,18 \\
\text { Sept. } 16,17 .\end{array}$ & $\begin{array}{l}6.3 \\
6.6\end{array}$ & $\begin{array}{l}\text { Aug. } 8 \\
\text { Sept. } 7\end{array}$ & $\begin{array}{l}6.3 \\
6.9\end{array}$ & Jur & 7.8 \\
\hline Not & 7.3 & Oct. 13. & 6.8 & Oct. 6 & 7.3 & $\begin{array}{l}\text { July } 1 \\
\text { Aug. } 1\end{array}$ & $\begin{array}{l}6.5 \\
6.7\end{array}$ \\
\hline Dec. 2 & 7.3 & $\begin{array}{l}\text { Nov. } 12- \\
\text { Dec. } 10 . .\end{array}$ & $\begin{array}{l}6.8 \\
7.0 \\
\end{array}$ & $\begin{array}{l}\text { Nov. } 4 . . . \\
\text { Dec. } 2 \ldots\end{array}$ & $\begin{array}{l}7.2 \\
7.7 \\
\end{array}$ & Sept. 28 & $\begin{array}{l}\text { 7. } \\
\text { 7. }\end{array}$ \\
\hline $\begin{array}{l}\text { Lowest_... } \\
\text { A verage.. }\end{array}$ & $\begin{array}{l}7.9 \\
7.00 \\
\end{array}$ & $\begin{array}{l}\text { Lowest...... } \\
\text { A verage.... }\end{array}$ & $\begin{array}{l}7.9 \\
6.85 \\
\end{array}$ & $\begin{array}{l}\text { Lowest... } \\
\text { A verage.. }\end{array}$ & $\begin{array}{l}8.2 \\
7.15 \\
\end{array}$ & $\begin{array}{l}\text { Lowest.. } \\
\text { A verage. }\end{array}$ & $\begin{array}{l}7.8 \\
7.17 \\
\end{array}$ \\
\hline
\end{tabular}


TABLE 6.-Monthly extreme low water below sea-level datum, Boston Navy YardContinued

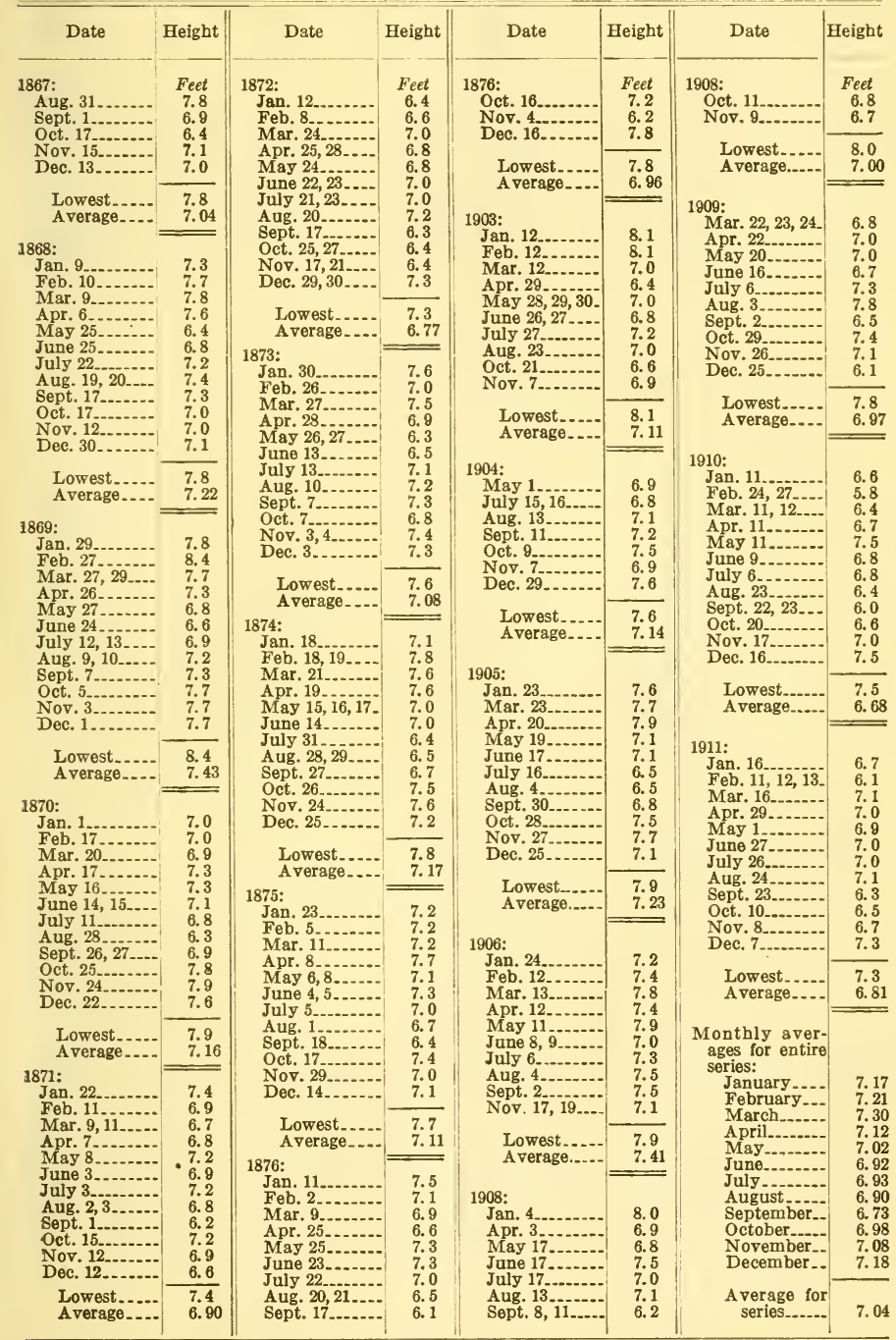


TABLE 7.-Mean tide level on original tide scale, Boston Navy Yard

\begin{tabular}{|c|c|c|c|c|c|c|c|}
\hline Year & $\begin{array}{c}\text { Mean } \\
\text { tide } \\
\text { level }\end{array}$ & Year & $\begin{array}{c}\text { Mean } \\
\text { tide } \\
\text { level }\end{array}$ & Year & $\begin{array}{c}\text { Mean } \\
\text { tide } \\
\text { level }\end{array}$ & Year & $\begin{array}{c}\text { Mean } \\
\text { tide } \\
\text { level }\end{array}$ \\
\hline $\begin{array}{l}18471 \\
1848 \\
1849 \\
1850 \\
1851 \\
1852 \\
1853 \\
1854 \\
1855 \\
1856\end{array}$ & $\begin{array}{l}\text { Feet } \\
20.24 \\
20.24 \\
20.23 \\
20.20 \\
20.20 \\
20.25 \\
20.26 \\
20.10 \\
20.22 \\
20.28\end{array}$ & $\begin{array}{l}1857 \ldots \ldots \\
1858 \\
1859 \\
1860 \\
1861 \\
1862 \\
1863 \ldots \\
1864 \\
1865 \\
1866\end{array}$ & $\begin{array}{l}\text { Feet } \\
20.20 \\
20.08 \\
20.06 \\
20.04 \\
20.12 \\
20.14 \\
20.12 \\
20.08 \\
20.12 \\
20.06\end{array}$ & $\begin{array}{l}18671 \ldots \ldots \\
1868 \\
1869 \\
1870 \ldots 1 \\
1872 \ldots \ldots \\
1873 \ldots \\
1874 \\
1875\end{array}$ & $\begin{array}{l}\text { Feet } \\
20.14 \\
19.91 \\
20.03 \\
20.23 \\
20.02 \\
20.02 \\
20.14 \\
20.00 \\
20.04 \\
20.16\end{array}$ & 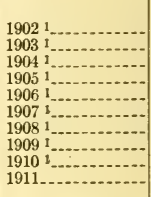 & $\begin{array}{l}\text { Feet } \\
20.25 \\
20.22 \\
20.03 \\
19.98 \\
19.95 \\
19.95 \\
20.05 \\
20.28 \\
20.06\end{array}$ \\
\hline Mean..... & 20.22 & Mean.... & 20.10 & Mean.... & 20.07 & Mean...... & 20.09 \\
\hline
\end{tabular}

1 Records for year incomplete; see note 1, Table 2, p. 50.

Mean tide level from entire series is 20.12 feet on original tide scale.

Above table is derived from the mean high and low water heights given in Table 2.

TABie 8.-Mean tide level referred to sea-level datum, Boston Navy Yard

\begin{tabular}{|c|c|c|c|c|c|c|c|}
\hline Year & $\begin{array}{c}\text { Mean } \\
\text { tide } \\
\text { level }\end{array}$ & Year & $\begin{array}{c}\text { Mean } \\
\text { tide } \\
\text { level }\end{array}$ & Year & $\begin{array}{c}\text { Mean } \\
\text { tide } \\
\text { level }\end{array}$ & Year & $\begin{array}{c}\text { Mean } \\
\text { tide } \\
\text { level }\end{array}$ \\
\hline $\begin{array}{l}1847{ }^{1} \ldots \ldots \\
1848 \\
1849 \\
1850 \\
1851 \\
1853 \\
1854 \\
1855 \\
1856\end{array}$ & $\begin{array}{c}\text { Feet } \\
0.06 \\
.06 \\
.05 \\
.02 \\
.02 \\
.07 \\
.08 \\
-.08 \\
.04 \\
.10\end{array}$ & $\begin{array}{l}1857 \\
1858 \\
1859 \\
1860 \\
1861 \\
1862 \\
1863 \\
1864 \\
1865 \\
1866\end{array}$ & $\begin{array}{c}\text { Feet } \\
0.02 \\
-.10 \\
-.12 \\
-.14 \\
-.06 \\
-.04 \\
-.06 \\
-.10 \\
-.06 \\
-.12\end{array}$ & $\begin{array}{l}1867{ }^{1} \ldots \\
1868 \\
1869 \\
1870 \\
1871 \\
1872 \\
1873 \\
1874 \\
1875\end{array}$ & $\begin{array}{c}\text { Feet } \\
-0.04 \\
-.27 \\
-.15 \\
.05 \\
-.16 \\
-.16 \\
-.04 \\
-.18 \\
-.14 \\
-.02\end{array}$ & 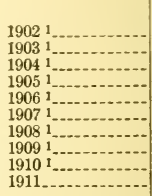 & $\begin{array}{r}\text { Feet } \\
0.07 \\
.04 \\
-.15 \\
-.20 \\
-.23 \\
-.23 \\
-.13 \\
-.10 \\
-.12\end{array}$ \\
\hline Mean. & .04 & Mean & -.08 & Mear & -.11 & Mean. & -.09 \\
\hline
\end{tabular}

1 Records for year incomplete; see note 1, Table 2, p. 50.

Mean tide level from entire series is 0.06 feet below sea-level datum.

Above table is derived by referring the values in Table 7 to the sea-level datum defined on p. 41 .

TABle 9.-High-water lunitidal interval, Commonwealth Pier No. 5

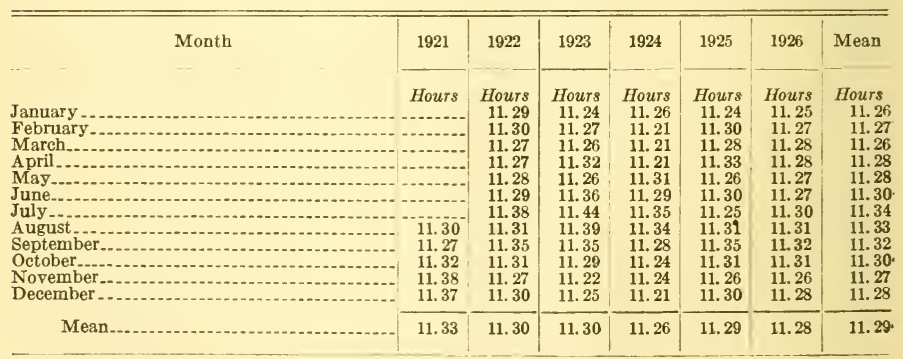


TIDES AND CURRENTS IN BOSTON HARBOR

Table 10.-Low-water lunitidal interval, Commonwealth Pier No. 5

\begin{tabular}{|c|c|c|c|c|c|c|c|}
\hline Month & 1921 & 1922 & 1923 & 1924 & 1925 & 1926 & Mean \\
\hline $\begin{array}{l}\text { January } \\
\text { February } \\
\text { March } \\
\text { April } \\
\text { May } \\
\text { June } \\
\text { August } \\
\text { September } \\
\text { October } \\
\text { November } \\
\text { December }\end{array}$ & $\begin{array}{r}\text { Hours } \\
5.04 \\
5.03 \\
5.07 \\
5.11 \\
5.06\end{array}$ & $\begin{array}{r}\text { Hours } \\
5.06 \\
5.05 \\
5.04 \\
5.03 \\
5.03 \\
5.04 \\
5.14 \\
5.04 \\
5.08 \\
5.09 \\
5.07 \\
5.07\end{array}$ & $\begin{array}{r}\text { Hours } \\
5.01 \\
5.01 \\
5.02 \\
4.99 \\
5.03 \\
5.06 \\
5.16 \\
5.10 \\
5.11 \\
5.06 \\
5.03 \\
5.01\end{array}$ & $\begin{array}{r}\text { Hours } \\
5.01 \\
4.98 \\
4.94 \\
4.96 \\
5.04 \\
5.04 \\
5.07 \\
5.05 \\
5.00 \\
4.99 \\
5.01 \\
4.95\end{array}$ & $\begin{array}{r}\text { Hours } \\
5.03 \\
5.03 \\
5.03 \\
5.04 \\
5.00 \\
5.03 \\
5.06 \\
5.04 \\
5.05 \\
5.08 \\
5.01 \\
5.04\end{array}$ & $\begin{array}{r}\text { Hours } \\
4.97 \\
5.01 \\
5.02 \\
5.02 \\
4.98 \\
5.00 \\
5.02 \\
5.04 \\
5.04 \\
5.04 \\
5.03 \\
5.03\end{array}$ & $\begin{array}{r}\text { Hours } \\
5.02 \\
5.02 \\
5.01 \\
5.01 \\
5.02 \\
5.03 \\
5.09 \\
5.05 \\
5.05 \\
5.05 \\
5.04 \\
5.03\end{array}$ \\
\hline Mean & 5.06 & 5. 06 & 5.05 & 5.00 & 5. 04 & 5.02 & 5.04 \\
\hline
\end{tabular}

TABLE 11.-Duration of rise of tide, Commonwealth Pier No. 5

\begin{tabular}{|c|c|c|c|c|c|c|c|}
\hline Month & 1921 & 1922 & 1923 & 1924 & 1925 & 1926 & Mean \\
\hline $\begin{array}{l}\text { January } \\
\text { February. } \\
\text { March } \\
\text { April } \\
\text { May } \\
\text { July } \\
\text { August } \\
\text { September } \\
\text { October } \\
\text { November } \\
\text { December }\end{array}$ & $\begin{array}{l}\text { Hours } \\
6.26 \\
6.24 \\
6.25 \\
6.27 \\
6.31\end{array}$ & $\begin{array}{r}\text { Hours } \\
6.23 \\
6.25 \\
6.23 \\
6.24 \\
6.25 \\
6.25 \\
6.24 \\
6.27 \\
6.27 \\
6.22 \\
6.20 \\
6.23\end{array}$ & $\begin{array}{r}\text { Hours } \\
6.23 \\
6.26 \\
6.24 \\
6.33 \\
6.23 \\
6.30 \\
6.28 \\
6.29 \\
6.24 \\
6.23 \\
6.19 \\
6.24\end{array}$ & $\begin{array}{r}\text { Hours } \\
6.25 \\
6.23 \\
6.27 \\
6.25 \\
6.27 \\
6.25 \\
6.28 \\
6.28 \\
6.28 \\
6.25 \\
6.23 \\
6.26\end{array}$ & $\begin{array}{r}\text { Hours } \\
6.21 \\
6.27 \\
6.25 \\
6.29 \\
6.26 \\
6.27 \\
6.19 \\
6.27 \\
6.30 \\
6.23 \\
6.25 \\
6.26\end{array}$ & $\begin{array}{r}\text { Hours } \\
6.28 \\
6.26 \\
6.26 \\
6.26 \\
6.29 \\
6.27 \\
6.28 \\
6.27 \\
6.28 \\
6.27 \\
6.23 \\
6.25\end{array}$ & $\begin{array}{r}\text { Hours } \\
6.24 \\
6.25 \\
6.25 \\
6.27 \\
6.26 \\
6.27 \\
6.25 \\
6.27 \\
6.27 \\
6.24 \\
6.23 \\
6.26\end{array}$ \\
\hline Mean & 6.27 & 6. 24 & 6.25 & 6.26 & 6.25 & 6.27 & 6.25 \\
\hline
\end{tabular}

TABLE 12.-Mean high water on tide staff, Commonwealth Pier No. 5

\begin{tabular}{|c|c|c|c|c|c|c|c|}
\hline Month & 1921 & 1922 & 1923 & 1924 & 1925 & 1926 & Mean \\
\hline $\begin{array}{l}\text { January } \\
\text { February } \\
\text { March } \\
\text { A pril } \\
\text { May } \\
\text { June } \\
\text { July } \\
\text { August } \\
\text { September } \\
\text { October } \\
\text { November } \\
\text { December }\end{array}$ & \begin{tabular}{|l} 
Feet \\
12.78 \\
12.91 \\
12.89 \\
12.99 \\
12.71
\end{tabular} & $\begin{array}{l}\text { Feet } \\
12.44 \\
12.57 \\
12.72 \\
12.81 \\
12.76 \\
12.94 \\
12.97 \\
12.98 \\
12.92 \\
12.91 \\
12.89 \\
12.68\end{array}$ & $\begin{array}{l}\text { Feet } \\
12.74 \\
12.69 \\
12.79 \\
12.89 \\
12.87 \\
12.94 \\
12.80 \\
12.75 \\
12.65 \\
12.73 \\
12.93 \\
12.73\end{array}$ & $\begin{array}{l}\text { Feet } \\
12.47 \\
12.88 \\
13.21 \\
12.93 \\
12.93 \\
12.83 \\
12.75 \\
12.83 \\
12.94 \\
12.86 \\
12.80 \\
12.53\end{array}$ & $\begin{array}{l}\text { Feet } \\
12.63 \\
12.57 \\
12.47 \\
12.62 \\
12.69 \\
12.78 \\
12.83 \\
12.85 \\
12.88 \\
12.81 \\
12.66 \\
12.66\end{array}$ & $\begin{array}{l}\text { Feet } \\
12.37 \\
12.93 \\
12.51 \\
12.65 \\
12.70 \\
12.76 \\
12.85 \\
12.96 \\
12.79 \\
12.78 \\
12.50 \\
12.62\end{array}$ & $\begin{array}{r}\text { Feet } \\
12.53 \\
12.73 \\
12.74 \\
12.78 \\
12.79 \\
12.85 \\
12.84 \\
12.86 \\
12.85 \\
12.83 \\
12.80 \\
12.66\end{array}$ \\
\hline Mean & 12.86 & 12.80 & 12. 79 & 12.83 & 12. 70 & 12.70 & 12.77 \\
\hline
\end{tabular}

The above heights are referred to the tide staff installed in September, 1922, the zero of which is 21.45 feet below bench mark 7 . 
TABle 13.-Mean high water above sea-level datum, Commonwealth Pier No. 5

\begin{tabular}{|c|c|c|c|c|c|c|c|}
\hline Month & 1921 & 1922 & 1923 & 1924 & 1925 & 1926 & Mean \\
\hline $\begin{array}{l}\text { January } \\
\text { February } \\
\text { March } \\
\text { April } \\
\text { May } \\
\text { June } \\
\text { July } \\
\text { August } \\
\text { September } \\
\text { October } \\
\text { November } \\
\text { December }\end{array}$ & $\begin{array}{l}\text { Feet } \\
4.76 \\
4.76 \\
4.84 \\
4.56\end{array}$ & $\begin{array}{l}\text { Feet } \\
4.29 \\
4.42 \\
4.57 \\
4.66 \\
4.61 \\
4.79 \\
4.82 \\
4.83 \\
4.77 \\
4.76 \\
4.74 \\
4.53\end{array}$ & $\begin{array}{c}\text { Feet } \\
4.59 \\
4.54 \\
4.64 \\
4.74 \\
4.72 \\
4.79 \\
4.65 \\
4.60 \\
4.50 \\
4.58 \\
4.78 \\
4.58\end{array}$ & $\begin{array}{c}\text { Feet } \\
4.32 \\
4.73 \\
5.06 \\
4.78 \\
4.78 \\
4.68 \\
4.60 \\
4.68 \\
4.79 \\
4.71 \\
4.65 \\
4.38\end{array}$ & \begin{tabular}{c|} 
Feet \\
4.48 \\
4.42 \\
4.32 \\
4.47 \\
4.54 \\
4.63 \\
4.68 \\
4.70 \\
4.73 \\
4.66 \\
4.51 \\
4.51
\end{tabular} & $\begin{array}{c}\text { Feet } \\
4.22 \\
4.78 \\
4.36 \\
4.50 \\
4.55 \\
4.61 \\
4.70 \\
4.81 \\
4.64 \\
4.63 \\
4.35 \\
4.47\end{array}$ & $\begin{array}{r}\text { Feet } \\
4.38 \\
4.58 \\
4.59 \\
4.63 \\
4.64 \\
4.70 \\
4.69 \\
4.71 \\
4.70 \\
4.68 \\
4.65 \\
4.51\end{array}$ \\
\hline Mean & 4. 71 & 4. 65 & 4.64 & 4.68 & 4.55 & 4.55 & 4.62 \\
\hline
\end{tabular}

Above table is derived by referring the values in Table 12 to the sea-level datum defined on p. 41.

TABLE 14.- Mean low water on tide staff, Commonwealth Pier No. 5

\begin{tabular}{|c|c|c|c|c|c|c|c|}
\hline Month & 1921 & 1922 & 1923 & 1924 & 1925 & 1926 & Mean \\
\hline $\begin{array}{l}\text { January } \\
\text { February } \\
\text { March } \\
\text { April } \\
\text { May } \\
\text { June } \\
\text { July } \\
\text { August } \\
\text { September } \\
\text { October } \\
\text { November } \\
\text { December }\end{array}$ & $\begin{array}{l}\text { Feet } \\
-1.0 . \\
3.05 \\
3.15 \\
3.42 \\
3.25 \\
\end{array}$ & $\begin{array}{r}\text { Feet } \\
2.79 \\
2.84 \\
3.01 \\
3.12 \\
3.12 \\
3.21 \\
3.16 \\
3.16 \\
3.20 \\
3.31 \\
3.35 \\
3.14\end{array}$ & \begin{tabular}{l|} 
Feet \\
3.28 \\
3.01 \\
2.88 \\
3.00 \\
3.02 \\
3.26 \\
3.08 \\
3.08 \\
3.08 \\
3.21 \\
3.36 \\
3.11
\end{tabular} & $\begin{array}{r}\text { Feet } \\
2.81 \\
3.11 \\
\text { 3. } 45 \\
\text { 3. } 18 \\
\text { 3. } 32 \\
\text { 3. } 27 \\
\text { 3. } \\
\text { 3. } 27 \\
3.02 \\
3.19 \\
3.08 \\
2.74\end{array}$ & $\begin{array}{l}\text { Feet } \\
3.10 \\
2.84 \\
2.87 \\
3.13 \\
3.25 \\
3.17 \\
3.14 \\
3.12 \\
3.23 \\
3.15 \\
3.14 \\
3.19\end{array}$ & $\begin{array}{c}\text { Feet } \\
2.95 \\
3.28 \\
2.87 \\
3.04 \\
3.19 \\
3.11 \\
3.15 \\
3.22 \\
3.28 \\
3.50 \\
3.19 \\
3.35 \\
\end{array}$ & $\begin{array}{r}\text { Feet } \\
2.99 \\
3.02 \\
3.02 \\
3.09 \\
3.18 \\
3.20 \\
3.14 \\
3.15 \\
3.16 \\
3.25 \\
3.26 \\
3.13\end{array}$ \\
\hline Mean............ & 3.21 & 3.12 & 3.11 & 3.14 & 3.11 & 3.18 & 3. 13 \\
\hline
\end{tabular}

The above heights are referred to the tide staff installed in September, 1922, the zero of which is 21.45 feet below bench mark 7 .

TABLE 15.-Mean low water below sea-level datum, Commonwealth Pier No. 5

\begin{tabular}{|c|c|c|c|c|c|c|c|}
\hline Month & 1921 & 1922 & 1923 & 1924 & 1925 & 1926 & Mean \\
\hline $\begin{array}{l}\text { January } \\
\text { February } \\
\text { March } \\
\text { April } \\
\text { May } \\
\text { June } \\
\text { July } \\
\text { August } \\
\text { September } \\
\text { October } \\
\text { November } \\
\text { December }\end{array}$ & $\begin{array}{l}\text { Feet } \\
\\
5.10 \\
4.97 \\
5.00 \\
4.90 \\
\end{array}$ & $\begin{array}{c}\text { Feet } \\
5.36 \\
5.31 \\
5.14 \\
5.03 \\
5.03 \\
4.94 \\
4.99 \\
4.99 \\
4.95 \\
4.84 \\
4.80 \\
5.01\end{array}$ & $\begin{array}{l}\text { Feet } \\
4.87 \\
5.14 \\
5.27 \\
5.15 \\
5.13 \\
4.89 \\
5.07 \\
5.07 \\
5.07 \\
4.94 \\
4.79 \\
5.04\end{array}$ & $\begin{array}{r}\text { Feet } \\
5.34 \\
5.04 \\
4.70 \\
4.97 \\
4.83 \\
4.88 \\
4.96 \\
4.88 \\
5.13 \\
4.96 \\
5.07 \\
5.41\end{array}$ & $\begin{array}{c}\text { Feet } \\
5.05 \\
5.31 \\
5.28 \\
5.02 \\
4.90 \\
4.98 \\
5.01 \\
5.03 \\
4.92 \\
5.00 \\
5.01 \\
4.96\end{array}$ & $\begin{array}{c}\text { Feet } \\
5.20 \\
4.87 \\
5.28 \\
5.11 \\
4.96 \\
5.04 \\
5.00 \\
4.93 \\
4.87 \\
4.65 \\
4.96 \\
4.80\end{array}$ & $\begin{array}{r}\text { Feet } \\
5.16 \\
5.13 \\
5.13 \\
5.06 \\
4.97 \\
4.95 \\
5.01 \\
5.00 \\
4.99 \\
4.90 \\
4.89 \\
5.02\end{array}$ \\
\hline Mean... & 4. 94 & 5.03 & 5.04 & 5.01 & 5.04 & 4.97 & 5.02 \\
\hline
\end{tabular}

Above table is derived by referring the values in Table 14 to the sea-level datum defined on p. 41. 
TABLE 16.-Mean range of tide, Commonwealth Pier No. 5

\begin{tabular}{|c|c|c|c|c|c|c|c|}
\hline Month & 1921 & 1922 & 1923 & 1924 & 1925 & 1926 & Mean \\
\hline $\begin{array}{l}\text { January } \\
\text { February } \\
\text { March } \\
\text { April } \\
\text { May } \\
\text { June } \\
\text { July } \\
\text { August } \\
\text { September } \\
\text { October } \\
\text { November } \\
\text { December }\end{array}$ & \begin{tabular}{|l|} 
Feet \\
9.73 \\
9.73 \\
9.74 \\
9.57 \\
9.46
\end{tabular} & $\begin{array}{l}\text { Feet } \\
9.65 \\
9.73 \\
9.71 \\
9.69 \\
9.64 \\
9.73 \\
9.81 \\
9.82 \\
9.72 \\
9.60 \\
9.54 \\
9.54\end{array}$ & $\begin{array}{r}\text { Feet } \\
9.46 \\
9.68 \\
9.91 \\
9.89 \\
9.85 \\
9.68 \\
9.72 \\
9.67 \\
9.57 \\
9.52 \\
9.57 \\
9.62\end{array}$ & $\begin{array}{c}\text { Feet } \\
9.66 \\
9.77 \\
9.76 \\
9.75 \\
9.61 \\
9.56 \\
9.56 \\
9.56 \\
9.92 \\
9.67 \\
9.72 \\
9.79\end{array}$ & $\begin{array}{r}\text { Feet } \\
9.53 \\
9.73 \\
9.60 \\
9.49 \\
9.44 \\
9.61 \\
9.69 \\
9.73 \\
9.65 \\
9.66 \\
9.52 \\
9.47\end{array}$ & $\begin{array}{c}\text { Feet } \\
9.42 \\
9.65 \\
9.64 \\
9.61 \\
9.51 \\
9.65 \\
9.70 \\
9.74 \\
9.51 \\
9.28 \\
9.31 \\
9.27\end{array}$ & $\begin{array}{r}\text { Feet } \\
9.54 \\
9.71 \\
9.72 \\
9.69 \\
9.61 \\
9.65 \\
9.70 \\
9.71 \\
9.68 \\
9.58 \\
9.54 \\
9.53\end{array}$ \\
\hline Mean & 9.65 & 9.68 & 9.68 & 9.69 & 9.59 & 9.52 & 9.64 \\
\hline
\end{tabular}

Values in above table are differences between the mean high and low waters for each month as obtained directly from the observations. For mean range corrected for longitude of moon's node, see following table.

TABLE 17.-Mean range corrected for longitude of moon's node, Commonwealth Pier No.5

\begin{tabular}{|c|c|c|c|c|c|c|c|}
\hline Montb & 1921 & 1922 & 1923 & 1924 & 1925 & 1926 & Mean \\
\hline $\begin{array}{l}\text { January } \\
\text { February } \\
\text { March } \\
\text { April } \\
\text { May } \\
\text { June } \\
\text { July } \\
\text { August } \\
\text { September } \\
\text { October } \\
\text { November } \\
\text { December }\end{array}$ & $\begin{array}{c}\text { Feet } \\
\\
\\
\\
9.44 \\
9.44 \\
9.45 \\
9.28 \\
9.18\end{array}$ & $\begin{array}{c}\text { Feet } \\
9.36 \\
9.44 \\
9.42 \\
9.40 \\
9.35 \\
9.44 \\
9.52 \\
9.53 \\
9.43 \\
9.31 \\
9.25 \\
9.25 \\
\end{array}$ & $\begin{array}{r}\text { Feet } \\
9.18 \\
9.39 \\
9.61 \\
9.59 \\
9.59 \\
9.39 \\
9.43 \\
9.38 \\
9.28 \\
9.23 \\
9.28 \\
9.33 \\
\end{array}$ & $\begin{array}{c}\text { Feet } \\
9.47 \\
9.57 \\
9.56 \\
9.56 \\
9.42 \\
9.37 \\
9.37 \\
9.37 \\
9.72 \\
9.48 \\
9.53 \\
9.59\end{array}$ & $\begin{array}{r}\text { Feet } \\
9.34 \\
9.54 \\
9.41 \\
9.30 \\
9.25 \\
9.42 \\
9.50 \\
9.54 \\
9.46 \\
9.47 \\
9.33 \\
9.28 \\
\end{array}$ & $\begin{array}{c}\text { Feet } \\
9.33 \\
9.55 \\
9.54 \\
9.51 \\
9.41 \\
9.55 \\
9.60 \\
9.64 \\
9.41 \\
9.19 \\
9.22 \\
9.18 \\
\end{array}$ & $\begin{array}{r}\text { Feet } \\
9.34 \\
9.50 \\
9.51 \\
9.47 \\
9.40 \\
9.43 \\
9.48 \\
9.48 \\
9.46 \\
9.35 \\
9.31 \\
9.30\end{array}$ \\
\hline Mean & 9.36 & 9.39 & 9.39 & 9.50 & 9.40 & 9.43 & 9.42 \\
\hline
\end{tabular}

The above table is derived from Table 16 by applying factors depending upon the longitude of the moon's node. See p. 12. 
TABLE 18.-Monthly extreme high water above sea-level datum, Commonwealth Pier No. 5

\begin{tabular}{|c|c|c|c|c|c|c|c|}
\hline Date & Height & Date & Height & Date & Height & Date & Height \\
\hline 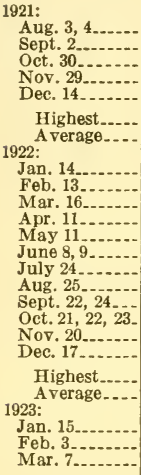 & $\begin{array}{c}\text { Feet } \\
6.7 \\
6.5 \\
6.9 \\
7.8 \\
6.6 \\
7.8 \\
6.90 \\
6.4 \\
6.7 \\
6.9 \\
7.5 \\
6.7 \\
6.4 \\
6.5 \\
6.5 \\
7.1 \\
6.6 \\
7.1 \\
6.5 \\
7.5 \\
6.74 \\
6.7 \\
7.0 \\
7.0\end{array}$ & 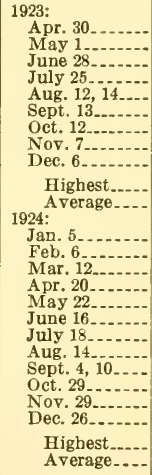 & $\begin{array}{l}\text { Feet } \\
7.2 \\
6.9 \\
6.9 \\
6.3 \\
6.0 \\
6.1 \\
6.5 \\
7.0 \\
7.2 \\
7.2 \\
6.73 \\
6.7 \\
7.3 \\
6.8 \\
6.8 \\
6.8 \\
6.9 \\
7.2 \\
6.5 \\
6.3 \\
7.1 \\
7.1 \\
6.8 \\
7.3 \\
6.86 \\
\end{array}$ & 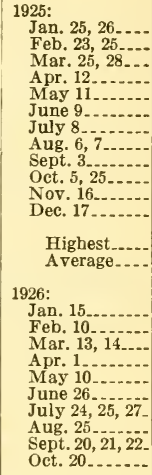 & $\begin{array}{c}\text { Feet } \\
6.7 \\
6.4 \\
5.5 \\
6.3 \\
6.2 \\
7.0 \\
6.8 \\
6.7 \\
6.7 \\
6.2 \\
6.9 \\
6.7 \\
7.0 \\
6.51 \\
\end{array}$ & 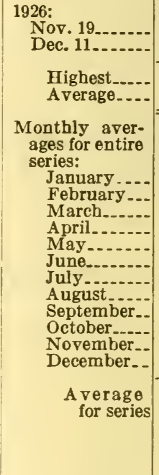 & $\begin{array}{l}6.76 \\
7.04 \\
6.56 \\
6.80 \\
6.58 \\
6.70 \\
6.62 \\
6.58 \\
6.57 \\
6.77 \\
7.15 \\
6.62\end{array}$ \\
\hline
\end{tabular}

Highest tide of these observations was 7.8 feet above the sea-level datum and occurred on No $.29,1921$ and on Feb. 10, 1926.

The heights in the above table are referred to the sea-level datum defined on p. 41 .

TABLE 19.-Monthly extreme low water below sea-level datum, Commonwealth Pier No. 5

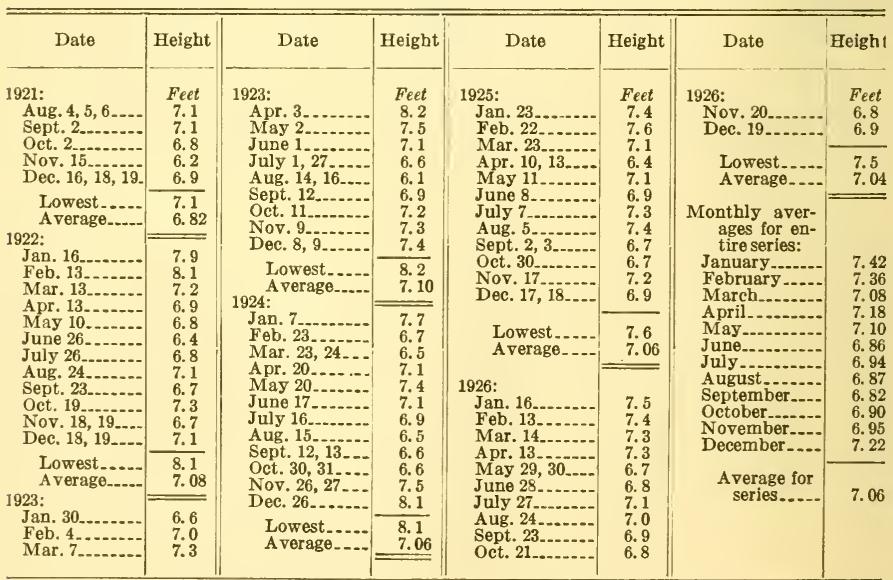

Lowest tide of these observations was 8.2 feet below the sea-level datum and occurred on Apr. 3, 1923 . The heights in the above table are referred to sea-level datum defined on p.41. 
TABLE 20.-Mean tide level on tide staff, Commonwealth Pier No. 5

\begin{tabular}{|c|c|c|c|c|c|c|c|}
\hline Month & 1921 & 1922 & 1923 & 1924 & 1925 & 1926 & Mean \\
\hline $\begin{array}{l}\text { January } \\
\text { February } \\
\text { March } \\
\text { April } \\
\text { May } \\
\text { June } \\
\text { July } \\
\text { August } \\
\text { September. } \\
\text { October } \\
\text { November } \\
\text { December }\end{array}$ & \begin{tabular}{l|} 
Feet \\
7.92 \\
8.04 \\
8.02 \\
7.20 \\
7.98
\end{tabular} & $\begin{array}{c}\text { Feet } \\
7.62 \\
7.70 \\
7.86 \\
7.96 \\
7.94 \\
8.08 \\
8.06 \\
8.07 \\
8.06 \\
8.11 \\
8.12 \\
7.91\end{array}$ & \begin{tabular}{l|} 
Feet \\
8.01 \\
7.85 \\
7.83 \\
7.94 \\
7.94 \\
8.10 \\
7.94 \\
7.92 \\
7.86 \\
7.97 \\
8.15 \\
7.92
\end{tabular} & $\begin{array}{l}\text { Feet } \\
7.64 \\
8.00 \\
8.33 \\
8.06 \\
8.12 \\
8.05 \\
7.97 \\
8.05 \\
7.98 \\
8.02 \\
7.94 \\
7.63\end{array}$ & $\begin{array}{l}\text { Feet } \\
7.86 \\
7.70 \\
7.67 \\
7.88 \\
7.97 \\
7.98 \\
7.98 \\
7.98 \\
8.06 \\
7.98 \\
7.90 \\
7.92\end{array}$ & $\begin{array}{l}\text { Feet } \\
7.66 \\
8.10 \\
7.69 \\
7.85 \\
7.94 \\
7.94 \\
8.00 \\
8.09 \\
8.04 \\
8.14 \\
7.84 \\
7.98\end{array}$ & $\begin{array}{r}\text { Feet } \\
7.76 \\
7.87 \\
7.88 \\
7.94 \\
7.98 \\
8.03 \\
7.99 \\
8.00 \\
8.01 \\
8.04 \\
8.02 \\
7.89\end{array}$ \\
\hline Mean._. & 8.03 & 7. 96 & 7. 95 & 7.98 & 7. 91 & 7.94 & 7.95 \\
\hline
\end{tabular}

The above heights are referred to the tide staff installed in September, 1922, the zero of which is 21.45 feet below bench mark 7 .

TABLE 21.-Mean tide level referred to sea-level datum, Commonwealth Pier No. 5

\begin{tabular}{|c|c|c|c|c|c|c|c|}
\hline Month & 1921 & 1922 & 1923 & 1924 & 1925 & 1926 & Mean \\
\hline $\begin{array}{l}\text { January } \\
\text { February- } \\
\text { March } \\
\text { April } \\
\text { May } \\
\text { June.. } \\
\text { July } \\
\text { August } \\
\text { September } \\
\text { October } \\
\text { November } \\
\text { December }\end{array}$ & $\begin{array}{c}\text { Feet } \\
\\
\end{array}$ & $\begin{array}{c}\text { Feet } \\
-0.53 \\
-.45 \\
-.29 \\
-.19 \\
-. .21 \\
-.07 \\
-.09 \\
-.08 \\
-.09 \\
-.04 \\
-.03 \\
-.24\end{array}$ & $\begin{array}{c}\text { Feet } \\
-0.14 \\
-.30 \\
-.32 \\
-.21 \\
-.21 \\
-.05 \\
-.21 \\
-.23 \\
-.29 \\
-.18 \\
-.00 \\
-.23\end{array}$ & $\begin{array}{c}\text { Feet } \\
-0.51 \\
-.15 \\
+.18 \\
-.09 \\
-.03 \\
-.10 \\
-.18 \\
-.10 \\
-.17 \\
-.13 \\
-.21 \\
-.52\end{array}$ & $\begin{array}{c}\text { Feet } \\
-0.29 \\
-.45 \\
-.48 \\
-.27 \\
-.18 \\
-.17 \\
-.17 \\
-.17 \\
-.09 \\
-.17 \\
-.25 \\
-.23\end{array}$ & $\begin{array}{c}\text { Feet } \\
-0.49 \\
-.05 \\
-.46 \\
-.30 \\
-.21 \\
-.21 \\
-.15 \\
=.06 \\
=.11 \\
=.01 \\
-.31 \\
-.17\end{array}$ & $\begin{array}{l}\text { Feet } \\
-0.39 \\
-.28 \\
-.27 \\
-.21 \\
-.17 \\
-.12 \\
=.16 \\
-.15 \\
=.14 \\
=.11 \\
-.13 \\
-. .26\end{array}$ \\
\hline Mean & -.12 & -.19 & -.20 & -.17 & -.24 & -.21 & -.20 \\
\hline
\end{tabular}

A bove table is derived by referring the values in Table 20 to the sea-level datum defined on p. 41.

TABLE 22.-Mean sea level on tide staff, Commonwealth Pier No. 5

\begin{tabular}{|c|c|c|c|c|c|c|c|}
\hline Month & 1921 & 1922 & 1923 & 1924 & 1925 & 1926 & Mean \\
\hline $\begin{array}{l}\text { January } \\
\text { February } \\
\text { March } \\
\text { A pril. } \\
\text { May- } \\
\text { June } \\
\text { July } \\
\text { August } \\
\text { September } \\
\text { October } \\
\text { November } \\
\text { December }\end{array}$ & $\begin{array}{c}\text { Feet } \\
\\
\\
8.17 \\
8.13 \\
8.10 \\
8.05 \\
\end{array}$ & $\begin{array}{c}\text { Feet } \\
7.76 \\
7.85 \\
8.02 \\
8.11 \\
8.09 \\
8.20 \\
8.22 \\
8.21 \\
8.18 \\
8.22 \\
8.22 \\
8.03\end{array}$ & $\begin{array}{c}\text { Feet } \\
8.14 \\
7.96 \\
7.96 \\
8.11 \\
8.09 \\
8.23 \\
8.06 \\
8.02 \\
7.98 \\
8.10 \\
8.26 \\
8.04\end{array}$ & $\begin{array}{c}\text { Feet } \\
7.75 \\
8.11 \\
8.44 \\
8.18 \\
8.26 \\
8.19 \\
8.08 \\
8.17 \\
8.12 \\
8.13 \\
8.06 \\
7.74\end{array}$ & $\begin{array}{l}\text { Feet } \\
7.97 \\
7.82 \\
7.79 \\
8.01 \\
8.10 \\
8.11 \\
8.11 \\
8.11 \\
8.18 \\
8.09 \\
8.01 \\
8.01\end{array}$ & $\begin{array}{c}\text { Feet } \\
7.77 \\
8.22 \\
7.81 \\
7.97 \\
8.07 \\
8.07 \\
8.14 \\
8.23 \\
8.15 \\
8.25 \\
7.96 \\
8.09\end{array}$ & $\begin{array}{r}\text { Feet } \\
7.88 \\
7.99 \\
8.00 \\
8.08 \\
8.12 \\
8.16 \\
8.12 \\
8.13 \\
8.13 \\
8.15 \\
8.13 \\
8.00\end{array}$ \\
\hline Mean.... & 8.15 & 8.09 & 8.08 & 8.10 & 8.03 & 8.06 & 8.07 \\
\hline
\end{tabular}

The above heights are referred to the tide staff installed in September, 1922, the zero of which is 21.45 feet below bench mark 7 .

$81772-28-5$ 
TABLE 23.-Mean sea level referred to sea-level datum, Commonwealth Pier No. $b$

\begin{tabular}{|c|c|c|c|c|c|c|c|}
\hline Month & 1921 & 1922 & 1923 & 1924 & 1925 & 1926 & Mean \\
\hline $\begin{array}{l}\text { January } \\
\text { February } \\
\text { March } \\
\text { April } \\
\text { May } \\
\text { June } \\
\text { July } \\
\text { August } \\
\text { September } \\
\text { Netober } \\
\text { November } \\
\text { December }\end{array}$ & $\begin{array}{c}\text { Feet } \\
\\
-0.10 \\
+.02 \\
-.02 \\
+.14 \\
-.05\end{array}$ & $\begin{array}{c}\text { Feet } \\
-0.39 \\
-.30 \\
-.13 \\
-.04 \\
-.06 \\
+.05 \\
+.07 \\
+.06 \\
+.03 \\
+.07 \\
+.07 \\
-.12\end{array}$ & $\begin{array}{c}\text { Feet } \\
-0.01 \\
-.19 \\
-.19 \\
-.04 \\
-.06 \\
+.08 \\
-.09 \\
-.13 \\
-.17 \\
-.05 \\
+.11 \\
-.11\end{array}$ & $\begin{array}{c}\text { Feet } \\
-0.40 \\
-.04 \\
+.09 \\
+.03 \\
+.11 \\
+.04 \\
-.07 \\
+.02 \\
-.03 \\
-.02 \\
-.09 \\
-.41\end{array}$ & $\begin{array}{c}\text { Feet } \\
-0.18 \\
-.33 \\
-.36 \\
-.14 \\
-.05 \\
-.04 \\
-.04 \\
-.04 \\
+.03 \\
-.06 \\
-.14 \\
-.14\end{array}$ & $\begin{array}{c}\text { Feet } \\
-0.38 \\
+.07 \\
-.34 \\
-.18 \\
-.08 \\
-.08 \\
-.01 \\
+.08 \\
.00 \\
+.10 \\
-.19 \\
-.06\end{array}$ & $\begin{array}{l}\text { Feet } \\
-0.27 \\
-.16 \\
-.15 \\
-.07 \\
-.03 \\
+.01 \\
-.03 \\
-.02 \\
-.02 \\
.00 \\
-.02 \\
-.15\end{array}$ \\
\hline 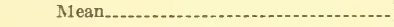 & .00 & -.06 & -.07 & -.05 & -.12 & -.09 & -.08 \\
\hline
\end{tabular}

Above table is derived by referring the values in Table 22 to the sea-level datum defined on p. 41.

TABLE 24.-Difference between mean sea level and mean tide level, Commonwealth Pier No. 5

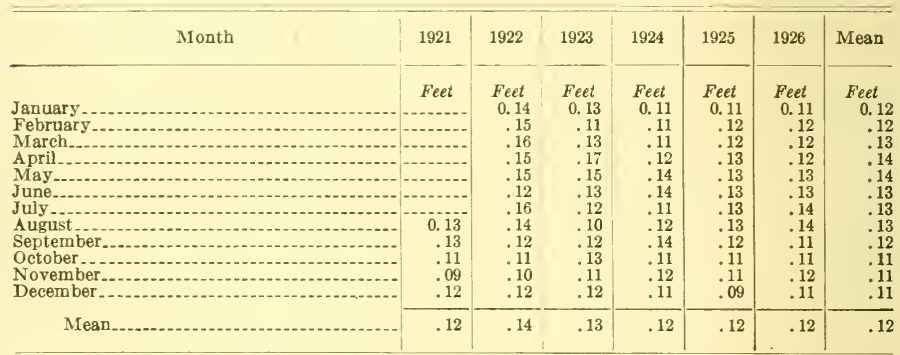

The above table was prepared by subtracting the mean tide level as computed from the high and low waters for each month from the mean sea level as computed from the hourly heights for the corresponding month.

TABLE 25.-Summary of time relations, Boston Navy Yard and Commonwealth Pier No. 5

\begin{tabular}{|c|c|c|}
\hline & Navy yard & $\begin{array}{l}\text { Commonwealth } \\
\text { Pier No. } 5\end{array}$ \\
\hline $\begin{array}{l}\text { Mean high-water lunitidal interval } \\
\text { Mean low-water lunitidal interval } \\
\text { Mean rise interval } \\
\text { Tropic higher } \text { high-water interval } \\
\text { Tropic lower high-water interval } \\
\text { Tropic higher low-water interval } \\
\text { Tropic lower low-water interval } \\
\text { Mean high-water interval (Greenwich) } \\
\text { Mean low-water interval (Greenwich) } \\
\text { Mean rise interval (Greenwich) } \\
\text { Mean duration of rise of tide } \\
\text { Mean duration of fall of tide } \\
\text { Phase age of tide } \\
\text { Parallax age of tide } \\
\text { Diurnal age of tide } \\
\text { Sequence of tide. }\end{array}$ & $\begin{array}{r}\text { Hours } \\
11.44 \\
5.23 \\
8.34 \\
11.36 \mathrm{a} \\
11.58 \mathrm{~b} \\
5.158 \\
5.46 \mathrm{~b} \\
3.92 \\
10.13 \\
.82 \\
6.21 \\
6.21 \\
38.0 \\
57.7 \\
19.1 \\
\text { HHW to LLW }\end{array}$ & $\begin{array}{c}\text { Hours } \\
11.29 \\
5.04 \\
8.17 \\
11.17 \mathrm{a} \\
11.40 \mathrm{~b} \\
4.90 \mathrm{a} \\
5.20 \mathrm{~b} \\
3.77 \\
9.94 \\
.65 \\
6.25 \\
6.17 \\
34.1 \\
52.2 \\
15.5 \\
\text { HHW to LLW }\end{array}$ \\
\hline
\end{tabular}

Times are given in hours and decimals. Intervals marked " $a$ " refer exclusively to the moon's upper meridian passage at its north declination and to the lower meridian passage at the south declination. Intervals marked " $b$ " refer exclusively to the moon's lower meridian passage at its nor th declination and to the upper meridian passage at the south declination.

For explanation of time relations, see pp. 10,17. 
TABLE 26.-Summary of ranges and inequalities, Boston Navy Yard and Commonwealth Pier No. 5

\begin{tabular}{|c|c|c|c|c|}
\hline & \multicolumn{2}{|c|}{ Navy yard } & \multicolumn{2}{|c|}{$\begin{array}{c}\text { Commonwealth Pier } \\
\text { No. } 5\end{array}$} \\
\hline & Magnitude & $\begin{array}{l}\text { Ratio to } \\
\text { mean range }\end{array}$ & Magnitude & $\begin{array}{l}\text { Ratio to } \\
\text { mean range }\end{array}$ \\
\hline $\begin{array}{l}\text { Mean range } \\
\text { Spring range. } \\
\text { Neap range } \\
\text { Perigean range. } \\
\text { A pogean range. } \\
\text { Great diurnal range } \\
\text { Small diurnal range } \\
\text { Great tropic range } \\
\text { Small tropic range } \\
\text { A verage monthly extreme range } \\
\text { Greatest range. } \\
\text { Diurnal high-water inequality } \\
\text { Diurnal low-water inequality } \\
\text { Spring tide level below mean tide level } \\
\text { Neap tide level above mean tide lvel } \\
\text { Mean tide level below mean sea level. }\end{array}$ & $\begin{array}{r}\text { Feet } \\
9.71 \\
11.09 \\
8.32 \\
11.37 \\
8.39 \\
10.44 \\
8.98 \\
10.24 \\
7.85 \\
13.93 \\
18.50 \\
.40 \\
.33 \\
.04 \\
.04 \\
.16\end{array}$ & $\begin{array}{r}1.000 \\
1.142 \\
.857 \\
1.171 \\
.864 \\
1.075 \\
.925 \\
1.055 \\
.808 \\
1.435 \\
1.905 \\
.041 \\
.034 \\
.004 \\
.004 \\
.016\end{array}$ & $\begin{array}{r}\text { Feet } \\
9.42 \\
10.89 \\
7.82 \\
11.20 \\
7.97 \\
10.21 \\
8.63 \\
9.93 \\
7.64 \\
13.79 \\
16.00 \\
.45 \\
.34 \\
.06 \\
.05 \\
.12\end{array}$ & $\begin{array}{r}1.000 \\
1.15 f \\
.830 \\
1.189 \\
.846 \\
1.084 \\
.916 \\
1.054 \\
.811 \\
1.464 \\
1.699 \\
.048 \\
.036 \\
.006 \\
.005 \\
.013\end{array}$ \\
\hline
\end{tabular}

For explanation of ranges and inequalities, see pp. 12, 17 .

TABLE 27.-Summary of tide planes, Boston Navy Yard and Commonwealth Pier No. 5

Highest tide observed

A verage of monthly highest

Perigean high water.

Mean higher high water

Tropic higher high water.

Mean high water.

Neap high water

Tropic lower high water

Mean sea level.

Sea-level datum

Neap tide level

Spring tide level

Tropic higher low water

Neap low water.

A pogean low water.

Mean higher low water

Boston low-water datum

Mean low water

Tropic lower low water

Mean lower low water

Spring low water.

Perigean low water

Average of monthly lowest

Lowest tide observed.

\begin{tabular}{|c|c|c|c|}
\hline \multicolumn{2}{|c|}{ Navy yard } & \multicolumn{2}{|c|}{$\begin{array}{c}\text { Commonwealth Pier } \\
\text { No. } 5\end{array}$} \\
\hline $\begin{array}{l}\text { Referred } \\
\text { to sea-level } \\
\text { datum }\end{array}$ & $\begin{array}{l}\text { Referred } \\
\text { to Boston } \\
\text { low-water } \\
\text { datum }\end{array}$ & $\begin{array}{l}\text { Referred } \\
\text { to sea-level } \\
\text { datum }\end{array}$ & $\begin{array}{l}\text { Referred } \\
\text { to Boston } \\
\text { low-water } \\
\text { datum }\end{array}$ \\
\hline $\begin{array}{c}\text { Feet } \\
10.1 \\
6.89 \\
5.63 \\
5.45 \\
5.20 \\
5.15 \\
4.80 \\
4.40 \\
4.14 \\
4.14 \\
3.78 \\
.10 \\
-.00 \\
-.02 \\
-.06 \\
-.10 \\
-4.07 \\
-4.18 \\
-4.25 \\
-4.58 \\
-4.87 \\
-4.91 \\
-5.09 \\
-5.24 \\
-5.64 \\
-5.74 \\
-7.04 \\
-8.4\end{array}$ & $\begin{array}{c}\text { Feet } \\
15.0 \\
11.76 \\
10.50 \\
10.32 \\
10.07 \\
10.02 \\
9.67 \\
9.27 \\
9.01 \\
9.01 \\
8.65 \\
4.97 \\
4.87 \\
4.85 \\
4.81 \\
4.77 \\
.80 \\
.69 \\
.62 \\
.29 \\
.00 \\
-.04 \\
-.22 \\
-.37 \\
-.77 \\
-.87 \\
-2.17 \\
-3.5\end{array}$ & $\begin{array}{c}\text { Feet } \\
7.8 \\
6.73 \\
5.47 \\
5.26 \\
5.03 \\
4.98 \\
4.58 \\
4.13 \\
3.91 \\
3.83 \\
3.67 \\
-.01 \\
-.00 \\
-.08 \\
-.13 \\
-.19 \\
-3.97 \\
-3.99 \\
-4.06 \\
-4.50 \\
-4.87 \\
-4.84 \\
-4.95 \\
-5.18 \\
-5.63 \\
-5.73 \\
-7.06 \\
-8.2\end{array}$ & $\begin{array}{c}\text { Feet } \\
12.7 \\
11.60 \\
10.34 \\
10.13 \\
9.90 \\
9.85 \\
9.45 \\
9.00 \\
8.78 \\
8.70 \\
8.54 \\
4.86 \\
4.87 \\
4.79 \\
4.74 \\
4.68 \\
.90 \\
.88 \\
.81 \\
.37 \\
.00 \\
. .03 \\
-.08 \\
-.81 \\
-.76 \\
-.86 \\
-2.10 \\
-3.3\end{array}$ \\
\hline
\end{tabular}

For explanation of tide planes, see p. 17. 
TABLE 28.-Tidal harmonic constants, Boston Navy Yard and Commonwealth Pier No. 5

\begin{tabular}{|c|c|c|c|c|c|c|c|c|}
\hline \multirow{3}{*}{ Component } & \multicolumn{2}{|c|}{ Navy yard, 1869} & \multicolumn{6}{|c|}{ Commonwealth Pier No. 5} \\
\hline & \multirow{2}{*}{ H } & \multirow{2}{*}{$\kappa$} & \multicolumn{2}{|c|}{1922} & \multicolumn{2}{|c|}{1924} & \multicolumn{2}{|c|}{ Means } \\
\hline & & & H & $\kappa$ & H & $\kappa$ & H & $\kappa$ \\
\hline $\begin{array}{l}0 \\
\end{array}$ & \begin{tabular}{c} 
Feet \\
$(0.029)$ \\
.443 \\
.182 \\
.303 \\
.030 \\
4.439 \\
.011 \\
.056 \\
.189 \\
.045 \\
1.017 \\
$(.115)$ \\
.365 \\
$(.016)$ \\
.148 \\
.057 \\
$(.009)$ \\
$(.006)$ \\
.003 \\
.707 \\
.004 \\
\hdashline$(.031)$ \\
.025 \\
.211 \\
$(.014)$ \\
.094 \\
.081
\end{tabular} & $\begin{array}{c}\circ \\
(151) \\
141 \\
16 \\
4 \\
121 \\
335 \\
248 \\
164 \\
262 \\
62 \\
304 \\
(283) \\
120 \\
(162) \\
137 \\
125 \\
(99) \\
(14) \\
78 \\
14 \\
229 \\
(353) \\
340 \\
306 \\
(111) \\
116 \\
99\end{array}$ & $\begin{array}{c}\text { Feet } \\
(0.025) \\
.449 \\
.350 \\
.264 \\
.023 \\
4.371 \\
.008 \\
.072 \\
.123 \\
.028 \\
.995 \\
.115 \\
.348 \\
(.014) \\
.158 \\
.070 \\
(.009) \\
(.006) \\
.017 \\
.699 \\
.003 \\
.007 \\
.046 \\
.045 \\
.218 \\
(.013) \\
.022 \\
.150 \\
.049\end{array}$ & $\begin{array}{c}\circ \\
(142) \\
134 \\
21 \\
15 \\
117 \\
330 \\
299 \\
107 \\
232 \\
19 \\
300 \\
287 \\
117 \\
(151) \\
135 \\
110 \\
(100) \\
(5) \\
76 \\
5 \\
210 \\
190 \\
16 \\
271 \\
310 \\
(110) \\
108 \\
143 \\
87\end{array}$ & $\begin{array}{c}\text { Feet } \\
(0.025) \\
.449 \\
.154 \\
.166 \\
.017 \\
4.407 \\
.004 \\
.063 \\
.128 \\
.027 \\
.986 \\
.148 \\
.371 \\
(.014) \\
.136 \\
(.072) \\
(.010) \\
(.006) \\
.031 \\
.721 \\
.007 \\
.009 \\
(.031) \\
(.106) \\
.192 \\
(.014) \\
-.155 \\
.155 \\
.150\end{array}$ & $\begin{array}{c}\circ \\
(145) \\
136 \\
8 \\
355 \\
127 \\
328 \\
229 \\
104 \\
225 \\
9 \\
302 \\
274 \\
119 \\
(153) \\
139 \\
(110) \\
(102) \\
(3) \\
100 \\
3 \\
183 \\
194 \\
(344) \\
(294) \\
27 \\
(111) \\
\cdots-14 \\
12 \\
12\end{array}$ & $\begin{array}{c}\text { Feet } \\
(0.025) \\
.449 \\
.252 \\
.215 \\
.020 \\
4.389 \\
.006 \\
.068 \\
.126 \\
.028 \\
.990 \\
.132 \\
.360 \\
(.014) \\
.147 \\
.071 \\
(.010) \\
(.006) \\
.024 \\
.710 \\
.005 \\
.008 \\
.038 \\
.076 \\
.205 \\
(.014) \\
.022 \\
.152 \\
.100\end{array}$ & $\begin{array}{c}0 \\
(143) \\
135 \\
14 \\
5 \\
122 \\
329 \\
264 \\
106 \\
229 \\
14 \\
301 \\
280 \\
118 \\
(152) \\
137 \\
110 \\
(101) \\
(4) \\
88 \\
4 \\
197 \\
192 \\
0 \\
283 \\
348 \\
(111) \\
108 \\
108 \\
49\end{array}$ \\
\hline
\end{tabular}

Values in parentheses are inferred. References to the harmonic constants in this table are given on pp. 14, 17 . 
TABle 29.-Tidal data, Boston Harbor, 1847-1926-Continued

\begin{tabular}{|c|c|c|c|c|c|c|c|c|}
\hline \multirow{2}{*}{$\begin{array}{l}\text { Sta- } \\
\text { tion } \\
\text { No. }\end{array}$} & \multirow{2}{*}{ Locality } & \multicolumn{2}{|c|}{ Observations } & \multicolumn{2}{|c|}{$\begin{array}{l}\text { Lunitidal } \\
\text { intervals }\end{array}$} & \multirow{2}{*}{$\begin{array}{l}\text { Dura: } \\
\text { tion of } \\
\text { rise }\end{array}$} & \multirow{2}{*}{$\begin{array}{l}\text { Mean } \\
\text { range }\end{array}$} & \multirow{2}{*}{ Compared with- } \\
\hline & & Year & Length & HWI & LWI & & & \\
\hline 19 & $\begin{array}{l}\text { Boston Harbor, Western } \\
\text { Shore Continued. } \\
\text { Cormmonwealth Pier } \\
\text { No. } 5\left(42^{\circ} 21^{\prime} \text { N., } 71^{\circ}\right. \\
03^{\prime} \text { W. }\end{array}$ & $\left\{\begin{array}{l}1922 \\
\text { to } \\
1926\end{array}\right.$ & 5 years & $\begin{array}{l}\text { Hours } \\
11.29\end{array}$ & $\begin{array}{c}\text { Hours } \\
5.04\end{array}$ & $\begin{array}{c}\text { Hours } \\
6.25\end{array}$ & $\begin{array}{l}\text { Feet } \\
9.42\end{array}$ & . \\
\hline 20 & $\begin{array}{l}\text { Castle Island }\left(42^{\circ} 20^{\prime}\right. \\
\text { N., } 71^{\circ} 01^{\prime} \text { W.) }\end{array}$ & $\left\{\begin{array}{l}1892 \\
1894\end{array}\right.$ & $\left\{\begin{array}{l}8 \text { days } \\
2 \text { days............. }\end{array}\right.$ & $\begin{array}{l}11.16 \\
11.24\end{array}$ & $\begin{array}{l}5.17 \\
5.21\end{array}$ & $\begin{array}{l}5.99 \\
6.03\end{array}$ & $\begin{array}{l}9.41 \\
9.59\end{array}$ & $\begin{array}{l}\text { Sandy Hook, N. J. } \\
\text { Fort Hamilton, N. } \\
\text { Y. }\end{array}$ \\
\hline 21 & $\begin{array}{l}\text { Railroad bridge, } \mathrm{Ne} \text { - } \\
\text { ponset River }\left(42^{\circ} 17^{\prime}\right.\end{array}$ & 1926 & 6 days.... & 11.26 & 5.06 & 6.20 & 9.51 & $\begin{array}{l}\text { Commonwealth } \\
\text { Pier No. } 5 \text {. }\end{array}$ \\
\hline 22 & $\begin{array}{l}\text { Moon Head }\left(42^{\circ} 19^{\prime}\right. \\
\text { N., } 70^{\circ} 59^{\prime} \text { W.) } \\
\text { Boston Harbor, Southern } \\
\text { Shore: }\end{array}$ & 1906 & 1 year & 11.14 & 4.94 & 6. 20 & 9.14 & $\begin{array}{l}\text { Fort Hamilton, N. } \\
\text { Y. }\end{array}$ \\
\hline 23 & $\left\{\begin{array}{l}\text { Nut Island }\left(42^{\circ} 17^{\prime} \text { N., }\right. \\
\left.70^{\circ} 57^{\prime} \mathrm{W} .\right)\end{array}\right.$ & $\left\{\begin{array}{l}1915 \\
1916 \\
1926\end{array}\right.$ & $\begin{array}{l}3 \text { months...- } \\
5 \text { months...- } \\
11 / 2 \text { months..- }\end{array}$ & $\begin{array}{l}11.56 \\
11.49 \\
11.37\end{array}$ & $\begin{array}{l}5.42 \\
5.26 \\
5.17\end{array}$ & $\begin{array}{l}6.14 \\
6.23 \\
6.20\end{array}$ & $\begin{array}{l}8.99 \\
8.99 \\
9.21\end{array}$ & $\begin{array}{l}\text { Portland, Me. } \\
\text { Do. } \\
\text { Commonwealth }\end{array}$ \\
\hline 24 & $\begin{array}{l}\text { Sheep Island, Hing- } \\
\text { ham Bay }\left(42^{\circ} 17^{\prime} \mathrm{N} .\right. \\
\left.70^{\circ} 55^{\prime} \mathrm{W} .\right)\end{array}$ & 1893 & 4 days..... & 11.50 & 5. 25 & 6. 25 & 9.51 & Fort Hamilton, $\mathrm{N}$. \\
\hline 25 & $\begin{array}{l}\text { Weymouth Fore Riv- } \\
\text { er Bridge }\left(42^{\circ} 15^{\prime} \mathrm{N} .,\right. \\
\left.70^{\circ} 58^{\prime} \mathrm{W} .\right)\end{array}$ & $\{1893$ & $\begin{array}{l}2 \text { days......... } \\
7 \text { days }\end{array}$ & $\begin{array}{l}11.30 \\
11.51\end{array}$ & $\begin{array}{l}5.15 \\
5.33\end{array}$ & $\begin{array}{l}6.15 \\
6.18\end{array}$ & $\begin{array}{r}10.30 \\
9.51\end{array}$ & $\begin{array}{l}\text { Do. } \\
\text { Commonwealth } \\
\text { Pier No. } 5 \text {. }\end{array}$ \\
\hline 26 & $\begin{array}{l}\text { Weymouth Back Riv- } \\
\text { er Bridge }\left(42^{\circ} 15^{\prime} \mathrm{N} .\right. \\
70^{\circ} 56^{\prime} \text { W. }\end{array}$ & 1893 & 1 day..... & 11.28 & 5. 23 & 6.05 & 8.40 & $\begin{array}{l}\text { Fort Hamilton, } N \text {. } \\
\text { Y. }\end{array}$ \\
\hline 27 & 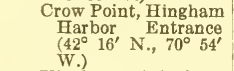 & 1926 & 20 days... & 11.41 & 5.28 & 6. 13 & 9.40 & $\begin{array}{l}\text { Commonwealth } \\
\text { Pier No. } 5 \text {. }\end{array}$ \\
\hline 28 & $\begin{array}{l}\text { Hingham, Hingham } \\
\text { Harbor }\left(42^{\circ} 15^{\prime} \text { N., }\right. \\
70^{\circ} 53^{\prime} \text { W.) }\end{array}$ & 1926 & 1 day.. & 11.35 & 5. 05 & 6.30 & 9.52 & Do. \\
\hline 29 & $\begin{array}{l}\text { Strawberry Hill, Hing- } \\
\text { ham Bay }\left(42^{\circ} 17^{\prime} \text { N., }\right. \\
\left.70^{\circ} 53^{\prime} \text { W. }\right)\end{array}$ & 1893 & 3 days.-.. & 11.33 & 5. 23 & 6.10 & 9.82 & $\begin{array}{l}\text { Fort Hamilton, N. } \\
\text { Y. }\end{array}$ \\
\hline
\end{tabular}

For reference to the observations listed in this table, see p. 1 . 
TABLE 30.-Adjusted tidal data, Boston Harbor

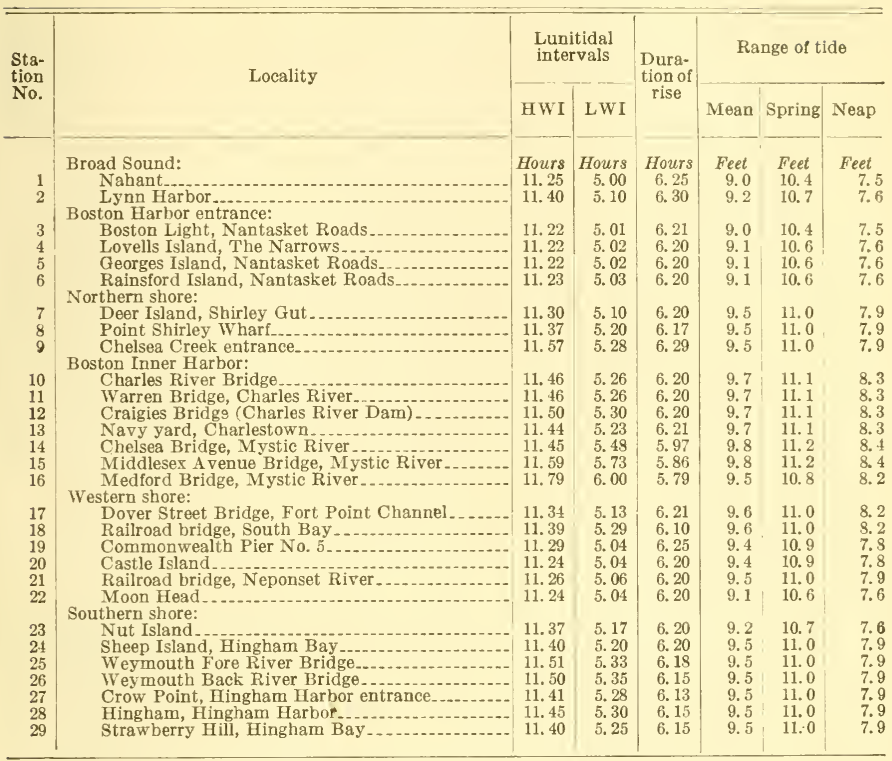

Note.-Tidal influences extend up the several rivers tributary to Boston Harbor as follows:

Chelsea River, 3 miles to a dam at Slade's Spice Mill.

Mystic River, 5 miles to a dam at Cradock Bridge, Medford.

Malden River, 2 miles above Its confluence with the Mystic River to a point beyond the Charles Street Bridge.

Charles River, 1 mile to the Charles River Dam.

Neponset River, 4 miles to a dam at Milton Lower Mills.

Weymouth Fore River, 6 miles to a dam at East Braintree.

Weymouth Back River, 4 miles to the highway bridge at East Weymouth.

For reference to above table, see p. 18 . 


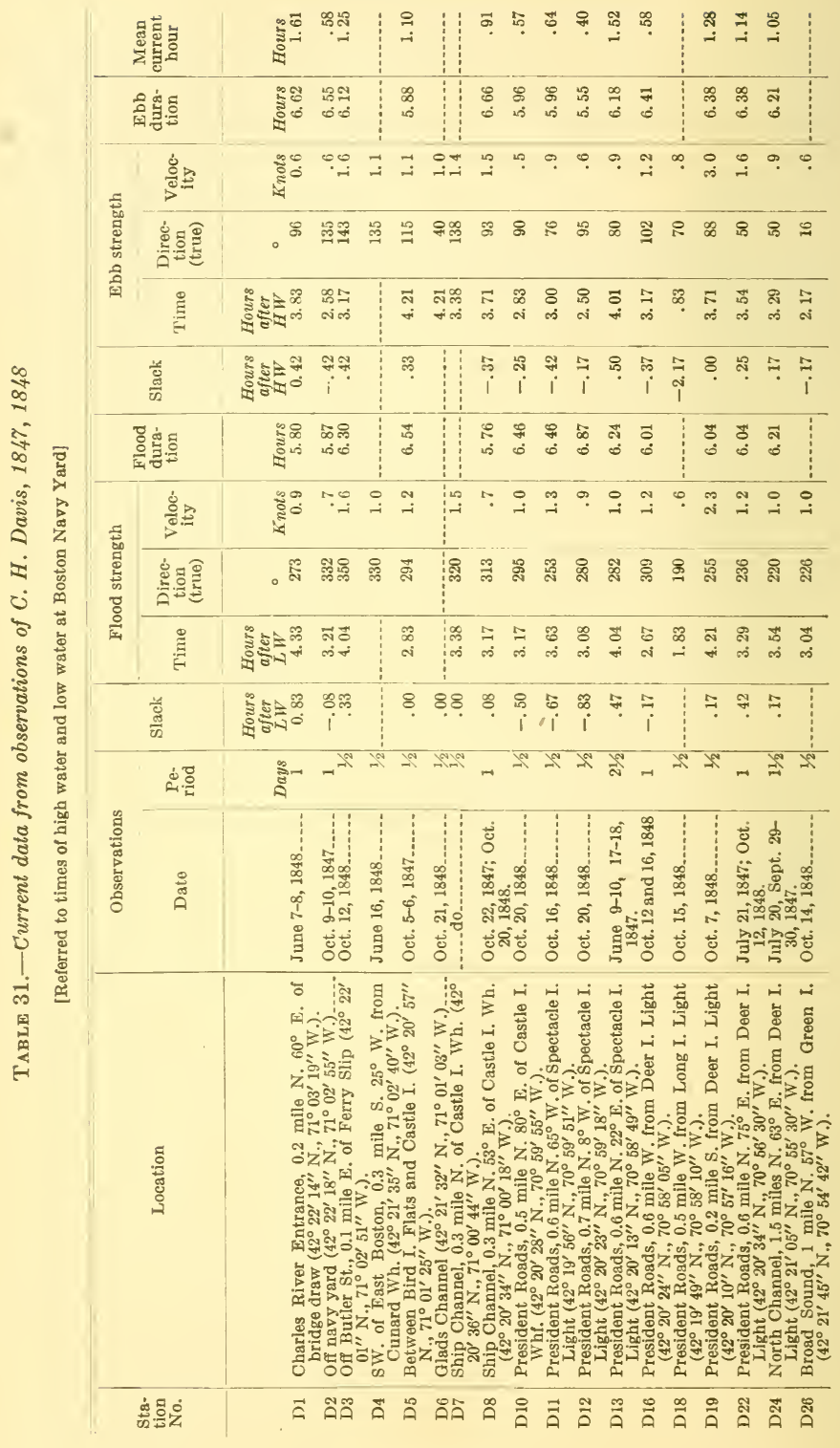




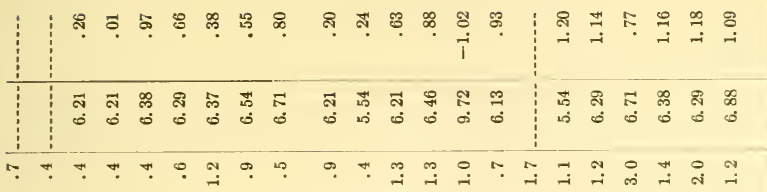

๓ ฌ 온

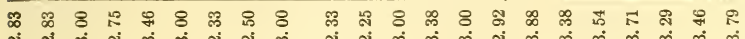

๓ $=$ ณ

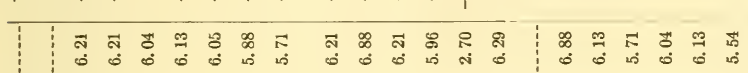

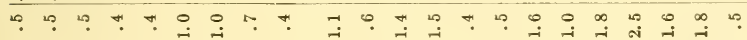

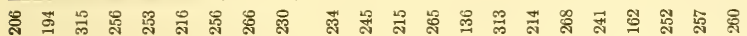
ำ

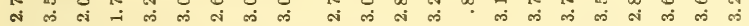
i

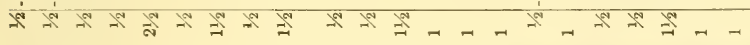

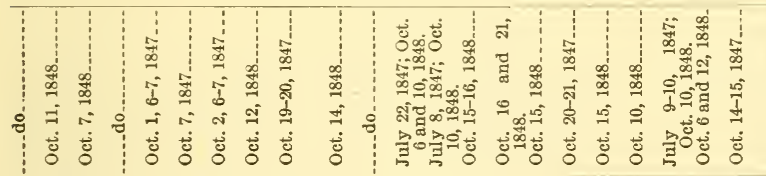

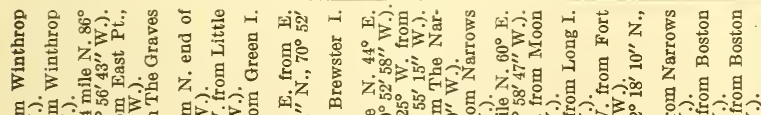

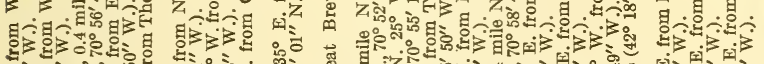

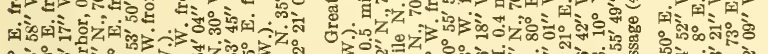

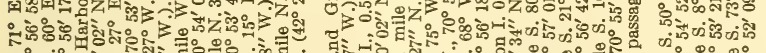

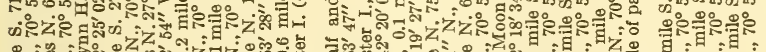

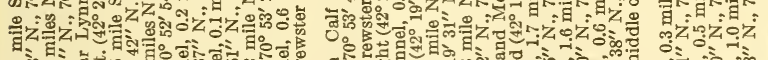

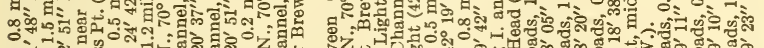
-

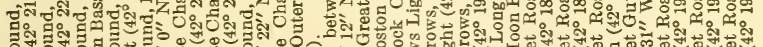

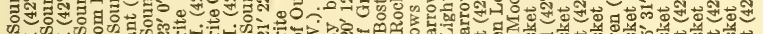
ช

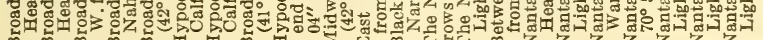
ต

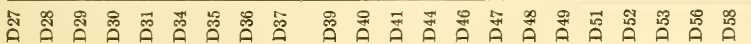




\begin{tabular}{|c|c|c|c|c|c|c|c|c|c|c|c|c|c|c|}
\hline \multicolumn{2}{|c|}{ 怘苛焉 } & 楚- & 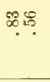 & - & $\begin{array}{c}\infty \\
\infty\end{array}$ & $\begin{array}{l}88 \\
8 \\
-1-i\end{array}$ & ஜे. & $\stackrel{\infty}{=}$ & ت્ & ติ & $\infty$ & II & 查 & $\infty$ \\
\hline \multicolumn{2}{|c|}{ 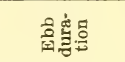 } & 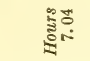 & 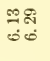 & 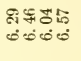 & $\stackrel{8}{6}$ & $\begin{array}{l}\text { Fंत } \\
\text { லं }\end{array}$ & : & $\begin{array}{l}\infty \\
\infty \\
\text { is }\end{array}$ & $\stackrel{\dddot{m}}{6}$ & 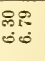 & $\begin{array}{l}\text { is } \\
\text { is }\end{array}$ & $\begin{array}{l}\mathscr{8} \\
8 \\
0\end{array}$ & $\begin{array}{l}8 \\
0 \\
0\end{array}$ & $\begin{array}{l}\text { i } \\
\text { is }\end{array}$ \\
\hline \multirow{3}{*}{ 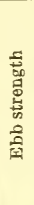 } & $\stackrel{\delta}{\circ}$ & ह్రీ: & $\infty$ & 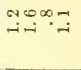 & $\stackrel{\circ}{-}$ & î: & $\infty$ & 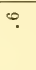 & $\stackrel{\text { N. }}{-}$ & $\dddot{x}$ & $\because$ & $\because$ & 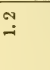 & 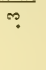 \\
\hline & 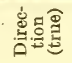 & $0^{5}$ & พฐ & 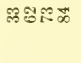 & $\bar{\infty}$ & 812 & $\stackrel{4}{7}$ & $\Xi$ & $\infty$ & 줌 & $\ddot{8}$ & ర్ర & $\cong$ & \& \\
\hline & $\stackrel{\Xi}{\Xi}$ & 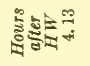 & $\begin{array}{l}\text { 동 } \\
\text { ம் }\end{array}$ & 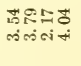 & 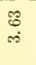 & 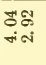 & $\begin{array}{c}\text { Sै } \\
\text { i }\end{array}$ & $\begin{array}{l}\overrightarrow{\text { N }} \\
\text { in }\end{array}$ & $\begin{array}{l}\infty \\
\infty \\
\infty\end{array}$ & $\begin{array}{l}=8 \\
\text { जi लि }\end{array}$ & $\begin{array}{l}\text { \&ิ } \\
\text { สิ }\end{array}$ & +ి & $\begin{array}{l}\overrightarrow{+} \\
\text { मे }\end{array}$ & $\begin{array}{l}\infty \\
\text { is }\end{array}$ \\
\hline \multicolumn{2}{|r|}{$\begin{array}{l}\text { 若 } \\
\frac{\pi}{60}\end{array}$} & 气ั๊ & $\stackrel{8}{*}$ & $\begin{array}{l}\infty 8 \% \% \\
i 1 i\end{array}$ & i & 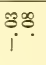 & $\stackrel{\infty}{i}$ & œ & œ. & 6.8 & $\stackrel{2}{?}$ & ॠ & จุ & ลำ \\
\hline \multicolumn{2}{|c|}{ 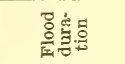 } & 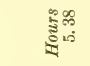 & Si: & 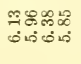 & $\begin{array}{l}\text { \& } \\
\text { is }\end{array}$ & $\begin{array}{l}\text { \&ี } \\
\text { में }\end{array}$ & $\begin{array}{l}8 \\
8\end{array}$ & $\begin{array}{l}\text { H. } \\
\text { is }\end{array}$ & 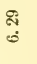 & $\begin{array}{l}\text { sig } \\
\text { ஸा }\end{array}$ & $\begin{array}{l}9 \\
6\end{array}$ & if & $\begin{array}{l}\mathscr{8} \\
\text { is }\end{array}$ & $\stackrel{0}{\sim}$ \\
\hline \multirow{3}{*}{ 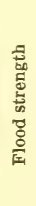 } & 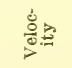 & 跣 & $\infty \infty$. & חָ & $\stackrel{\square}{\leftrightarrows}$ & $\because$ & $\because$ & $\because$ & $\stackrel{\overbrace{}}{-}$ & Nip & $\because$ & 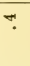 & $\because$ & $\infty$. \\
\hline & 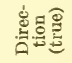 & 。范 & ๕્心 & 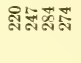 & ลิ & 高む & สิ & 亞 & ह్ & 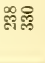 & 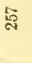 & 总 & 芦 & $\vec{\Phi}$ \\
\hline & $\underset{E}{\stackrel{g}{g}}$ & 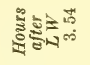 & $\begin{array}{l}g_{5}: 5 \\
\text { mos. }\end{array}$ & 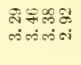 & $\begin{array}{l}\infty \\
\infty \\
\infty\end{array}$ & $\begin{array}{l}\qquad \infty \\
\infty \\
\text { is }\end{array}$ & $\stackrel{5}{\infty}$ & $\stackrel{m}{\rightleftarrows}$ & $\begin{array}{l}\infty \\
\infty \\
\infty\end{array}$ & 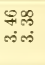 & $\begin{array}{l}\mathscr{8} \\
\ddot{\infty}\end{array}$ & $\vec{\infty}$ & $\begin{array}{l}\infty \\
\infty \\
\infty \\
\infty\end{array}$ & $\begin{array}{l}\infty \\
\infty \\
\infty\end{array}$ \\
\hline \multicolumn{2}{|r|}{ 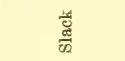 } & 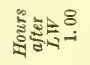 & $\stackrel{8}{8}$ & & $\stackrel{8}{i}$ & 중 & $i$ & 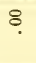 & \&: & i. & g & พู & 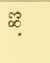 & $i$ \\
\hline \multirow{2}{*}{ 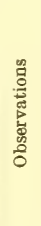 } & $\frac{d}{2}$ & 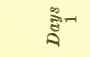 & & & - & $\rightarrow-$ & - & - & - & & - & - & - & - \\
\hline & 胥 & 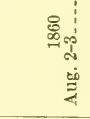 & 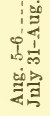 & 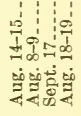 & 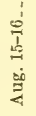 & 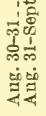 & 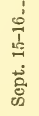 & 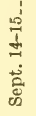 & 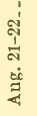 & 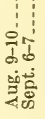 & 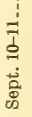 & $\begin{array}{c}\vdots \\
\vdots \\
\dot{0} \\
\dot{0} \\
0\end{array}$ & $\begin{array}{l}\text { जे } \\
\text { ปे } \\
\text { घं }\end{array}$ & $\begin{array}{l}\text { ล่ } \\
\text { à } \\
\text { है } \\
\text { है }\end{array}$ \\
\hline \multicolumn{2}{|r|}{ 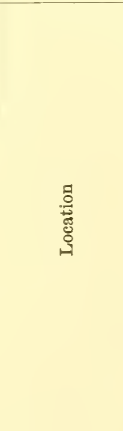 } & 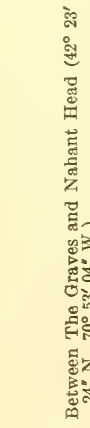 & 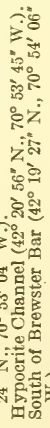 & 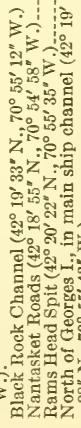 & 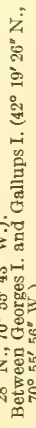 & 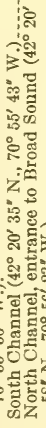 & 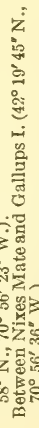 & 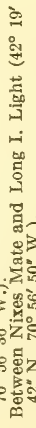 & 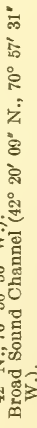 & 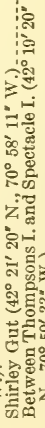 & 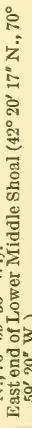 & 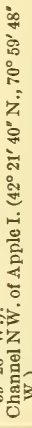 & 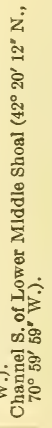 & 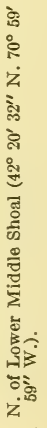 \\
\hline & క̃. & $\stackrel{\infty}{\Sigma}$ & 式究 & 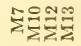 & $\underset{\Sigma}{E}$ & 政 & $\stackrel{9}{\mathrm{Z}}$ & 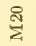 & $\overline{\sum_{1}}$ & สู่ะ్ & 太્ડ & 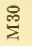 & 总 & 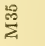 \\
\hline
\end{tabular}




\begin{tabular}{|c|c|c|c|c|c|c|c|c|c|c|c|c|c|}
\hline מૂఞ & 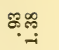 & & चี & ง & 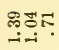 & & $\stackrel{\infty}{-}$ & 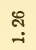 & $\stackrel{8}{:}$ & $\stackrel{\substack{\infty \\
-i}}{-\infty}$ & ঙ્- & $\stackrel{5}{-1}$ & is \\
\hline $\begin{array}{l}\infty R \\
\qquad R \\
\infty 00 \\
\infty\end{array}$ & $\begin{array}{l}780 \\
\therefore: 0 \\
\therefore=0\end{array}$ & F & $\begin{array}{l}7 \pi \\
7 \pi\end{array}$ & 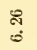 & 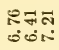 & הี & के & $\stackrel{\text { ลี }}{\stackrel{N}{*}}$ & b & $\stackrel{\text { సे }}{\stackrel{2}{\sim}}$ & कै & $\begin{array}{l}\text { Jे } \\
0\end{array}$ & $\begin{array}{l}\mathscr{8} \\
0 \\
0\end{array}$ \\
\hline ? & $\because ?$ & $\because$ & 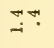 & $\because$ & 0.00 & & $\stackrel{\circ}{-}$ & $\because$ & $\stackrel{\circ}{i}$ & $\stackrel{\circ}{i}$ & $\stackrel{\sim}{-1}$ & $\theta$ & $\stackrel{0}{\circ}$ \\
\hline త్తే & $\nabla_{\infty}$ & 梁 & $\infty$ & $\Sigma$ & క్తజ్తస్త & & $\vec{m}$ & 政 & 효 & 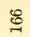 & $\overrightarrow{6}$ & 品 & స్త \\
\hline 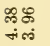 & 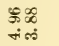 & $\begin{array}{l}\text { ศิ } \\
\text { ตे }\end{array}$ & 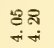 & 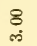 & $\begin{array}{l}=\infty 8 \\
\text { "अ }\end{array}$ & & 8 & กิ & శ్ల & 융 & $\stackrel{\Re}{\dddot{\leftrightarrow}}$ & $\begin{array}{l}\infty \\
\stackrel{\infty}{\infty} \\
\overbrace{}^{\circ}\end{array}$ & $\stackrel{2}{2}$ \\
\hline 88 & ణ & \&. & $\stackrel{9}{9}$ & 8 & 我우요 & 요 & 아. & ణ & 웅 & 8 & $\%$ & 욤 & $\stackrel{\substack{\infty \\
?}}{?}$ \\
\hline : & 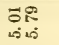 & $\underset{\text { Dे }}{\vec{S}}$ & $\begin{array}{l}\overrightarrow{5} \pi \\
\dot{0}+\pi\end{array}$ & $\begin{array}{l}0 \\
0\end{array}$ & 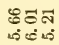 & ส & $\overline{0}$ & $\begin{array}{l}\overrightarrow{\text { A }} \\
\text { is }\end{array}$ & के & $\underset{\text { กิ }}{\tilde{S}}$ & $\underset{8}{\infty}$ & $\underset{\substack{0 \\
:}}{\infty}$ & $\underset{i n}{R}$ \\
\hline$\stackrel{\circ}{-}$ & $\because$ & & $\stackrel{9}{i}$. & $\because$ & 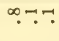 & & $\stackrel{\circ}{\circ}$ & 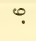 & $\because$ & $\because$ & $\vec{i}$ & ? & ? \\
\hline ; & 옥్ㅠ & & 吅怘 & $\mathscr{\varpi}$ & ग्न & & $\stackrel{\otimes}{\sim}$ & $\stackrel{\sim}{\infty}$ & జ్ల & $\stackrel{2}{\sim}$ & $\overline{\mathbb{Z}}$ & శ్ల & \&్ల \\
\hline $\begin{array}{l}\text { तु } \\
\text { ๓ं }\end{array}$ & 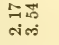 & & $\begin{array}{l}98 \\
\text { ம்+i }\end{array}$ & $\begin{array}{l}\infty \\
\infty \\
\text { i }\end{array}$ & 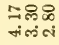 & & के & $\begin{array}{l}\text { श } \\
\text { ๓ }\end{array}$ & $\stackrel{ }{\stackrel{2}{*}}$ & $\stackrel{\varrho}{\stackrel{ }{*}}$ & $\begin{array}{l}\infty \\
\infty \\
\infty\end{array}$ & 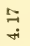 & $\underset{\sim}{~}$ \\
\hline 尔象 & 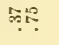 & 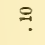 & 뭄요 & ? & 료 & F & คै. & $?$ & $\varnothing$ & 8 & $\stackrel{9}{?}$ & $\mathscr{~}$ & 8 \\
\hline- & $\rightarrow-1$ & - & $--^{-5}$ & $\cdots^{\infty}$ & & - & $-x$ & -2 & -5 & $\rightarrow$ & $\Rightarrow$ & - & 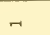 \\
\hline 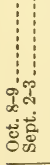 & 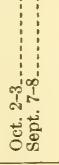 & 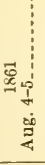 & 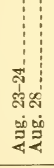 & 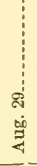 & 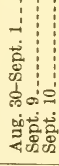 & 吕 & ठ̊ำ & 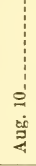 & $\begin{array}{l}\vec{z} \\
\vec{z} \\
\overrightarrow{4}\end{array}$ & 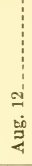 & 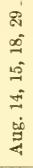 & $\begin{array}{l}\text { से } \\
\text { से } \\
\text { से } \\
\text { से }\end{array}$ & 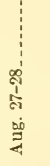 \\
\hline 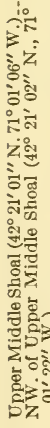 & 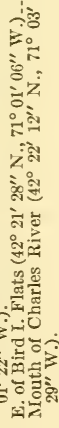 & 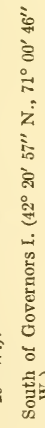 & 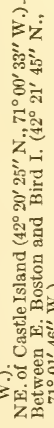 & 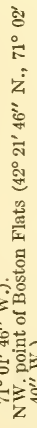 & 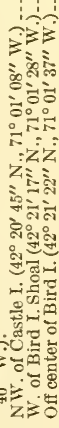 & 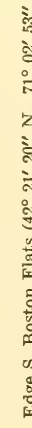 & 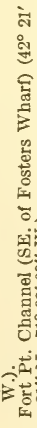 & 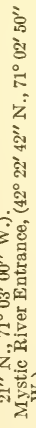 & 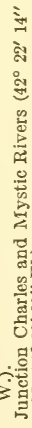 & 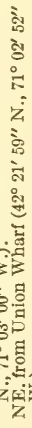 & 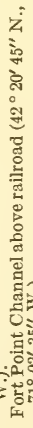 & 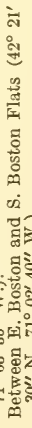 & 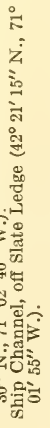 \\
\hline 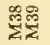 & 影莫 & 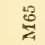 & 象 & 象 & 是政 & 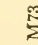 & 旁 & $\frac{2}{2}$ & $\stackrel{8}{E}$ & $\frac{5}{2}$ & 龸 & $\frac{9}{2}$ & $\frac{\nexists g}{\Sigma}$ \\
\hline
\end{tabular}




\begin{tabular}{|c|c|}
\hline 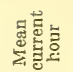 & ๓ \\
\hline 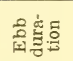 & 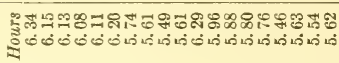 \\
\hline
\end{tabular}

형 훙

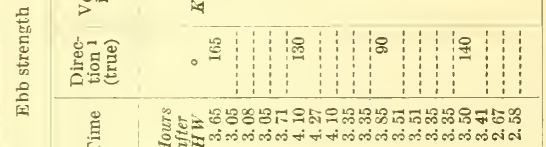

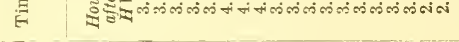

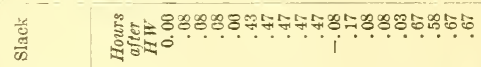

\begin{tabular}{|c|c|}
\hline 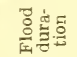 & 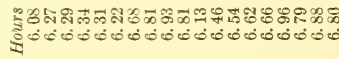 \\
\hline
\end{tabular}

\begin{tabular}{|c|c|c|c|c|}
\hline : & क्ष & $\therefore$ & $m^{\infty}$ & $-\approx$ \\
\hline
\end{tabular}

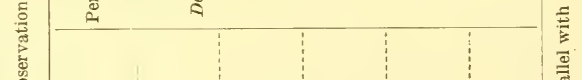

\begin{tabular}{|c|c|c|c|c|}
\hline$\stackrel{\Perp}{\Xi}$ & 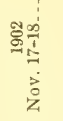 & 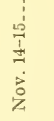 & $\frac{1}{2}$ & $\begin{array}{l}\frac{0}{d} \\
\dot{d} \\
\dot{0} \\
\dot{z}\end{array}$ \\
\hline 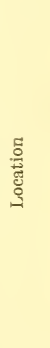 & 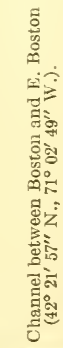 & 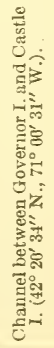 & 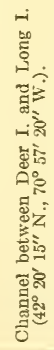 & 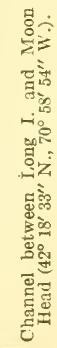 \\
\hline 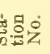 & ठ大 & ชิ & 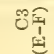 & ঠึ: \\
\hline
\end{tabular}




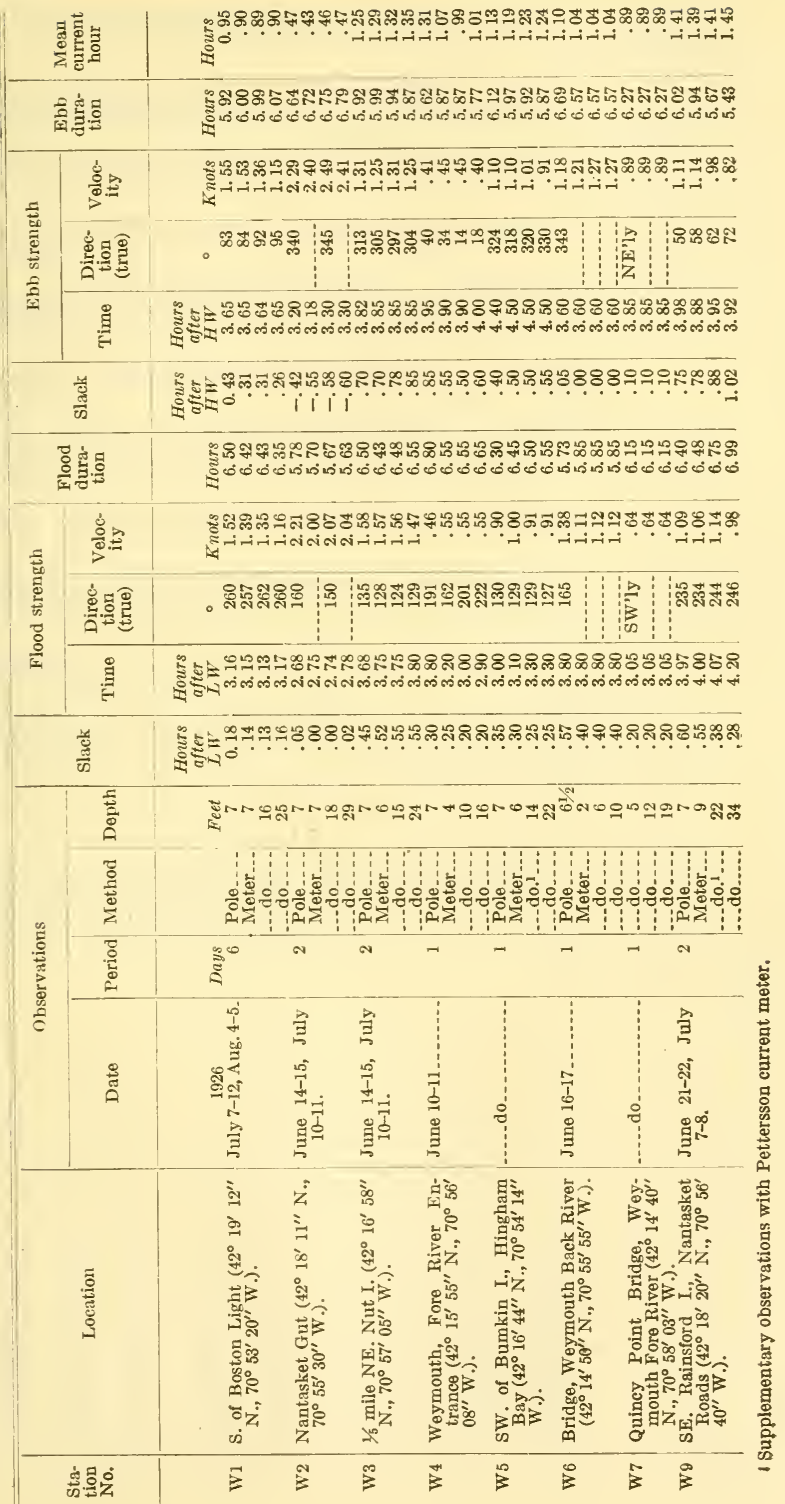




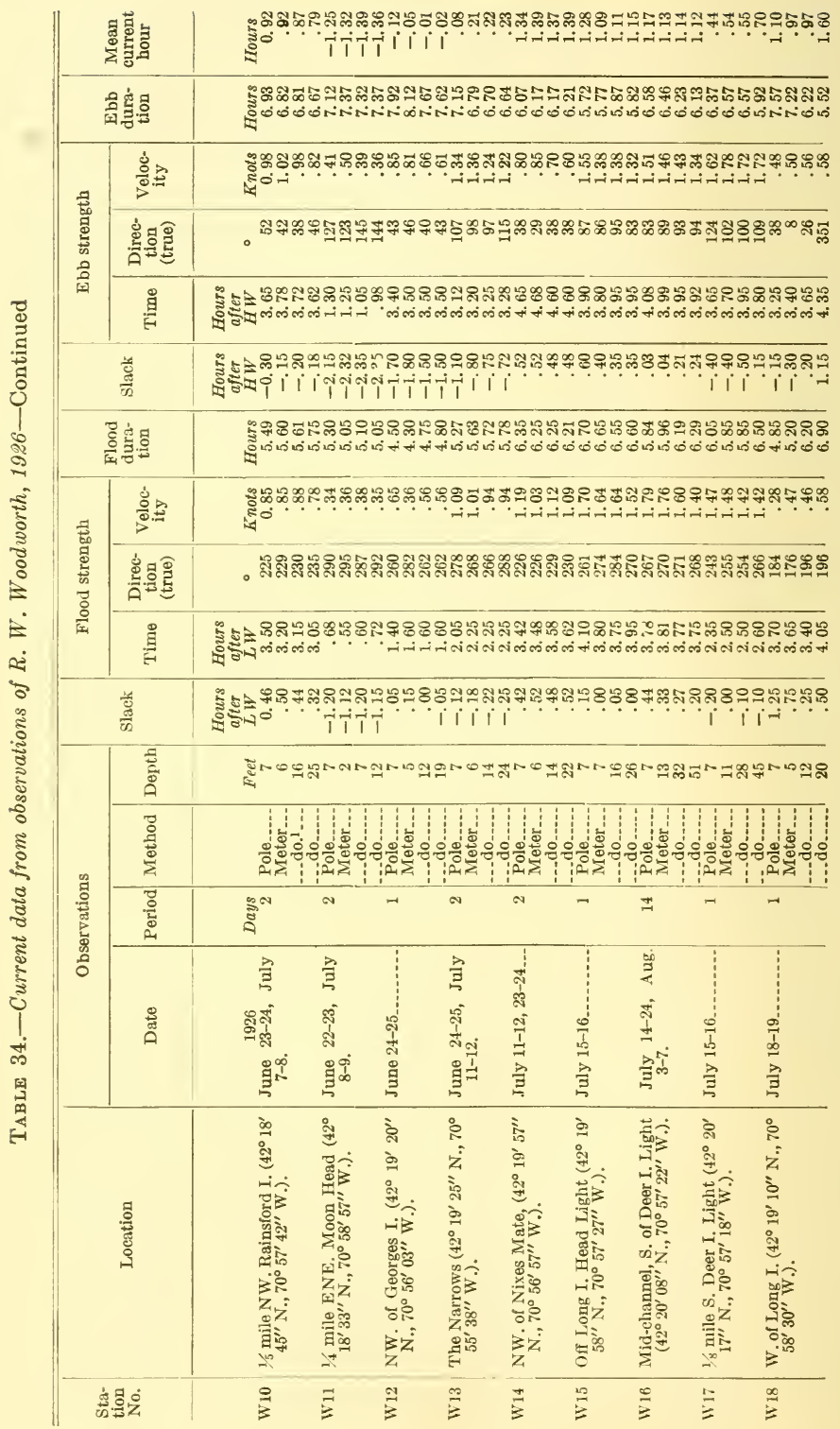




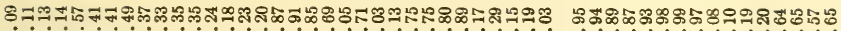
-i-iंi

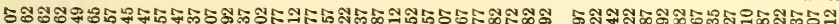

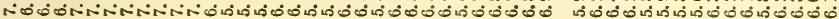

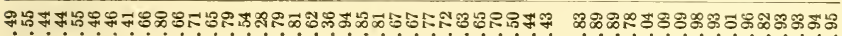

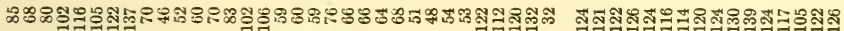

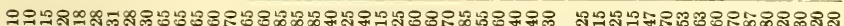

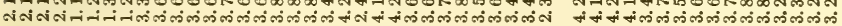

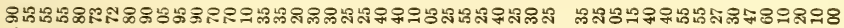

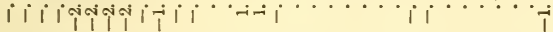

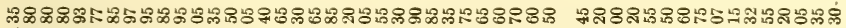

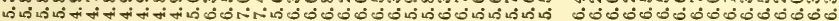

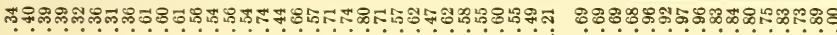

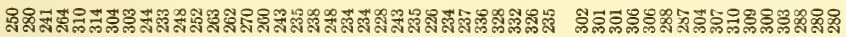

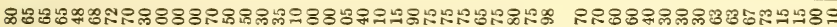

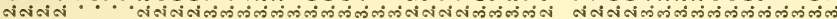

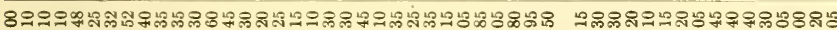
i i i-i-i

$x+\frac{100}{20}$

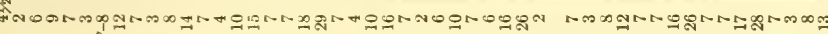

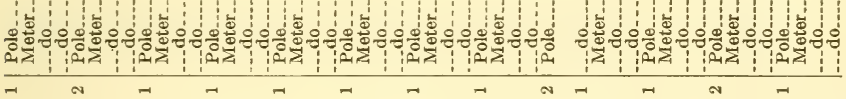

\begin{tabular}{|c|c|c|c|c|c|c|c|c|c|c|}
\hline 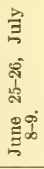 & 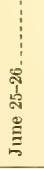 & 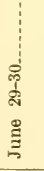 & $\stackrel{8}{\circ}$ & 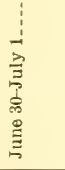 & : & $\frac{1}{\frac{1}{7}}$ & 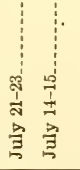 & 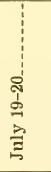 & $\begin{array}{l}\vec{\jmath} \\
\stackrel{d}{a} \\
\vec{\Delta} \\
\vec{\Xi}\end{array}$ & 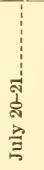 \\
\hline 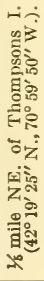 & 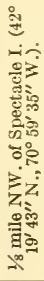 & 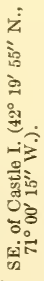 & 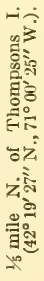 & 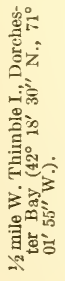 & 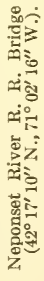 & 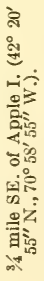 & 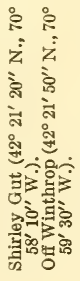 & 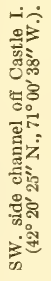 & 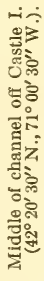 & 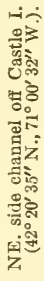 \\
\hline กิ & $\vec{N}$ & $\begin{array}{c}\text { สิ } \\
\text { క }\end{array}$ & $\stackrel{\mathscr{N}}{3}$ & $\stackrel{\pi}{N}$ & $\begin{array}{l}\text { ลิ } \\
\stackrel{2}{*}\end{array}$ & เั & $\stackrel{\text { A }}{3}$ & $\stackrel{\mathbb{N}}{3}$ & 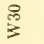 & $\vec{m}$ \\
\hline
\end{tabular}




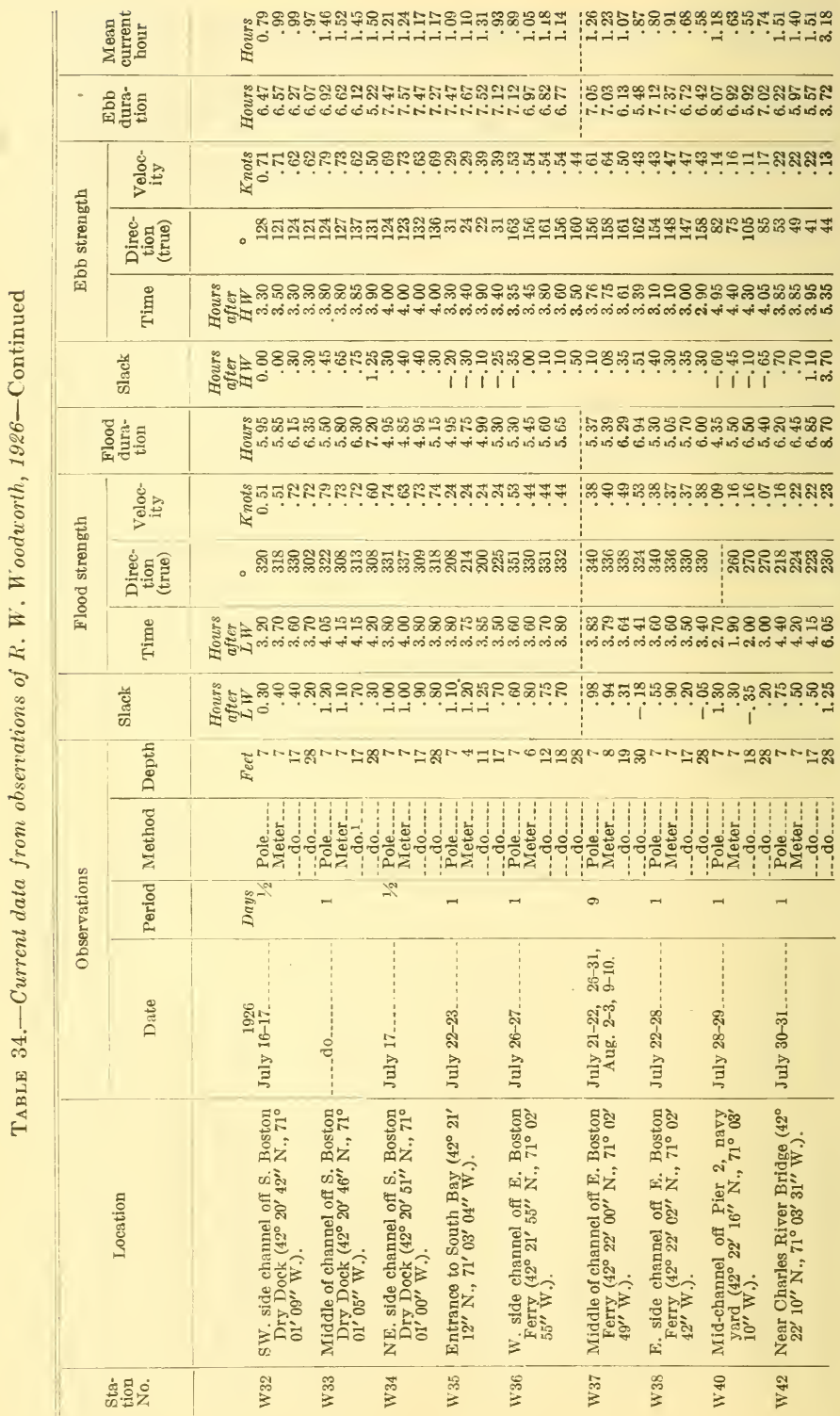


굮

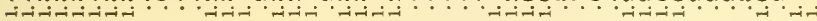

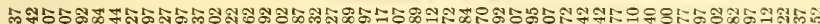

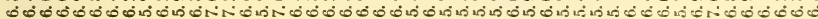

ตี

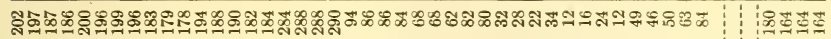

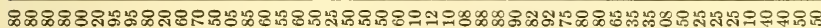

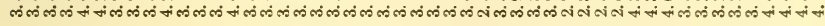

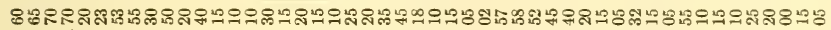
i i i i

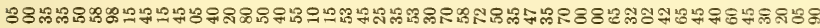

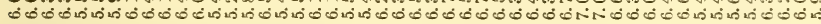

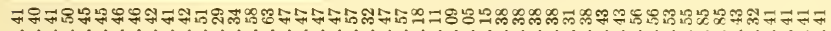

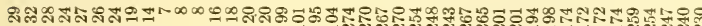

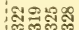

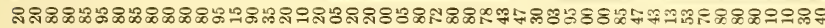

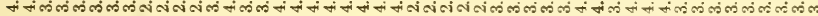

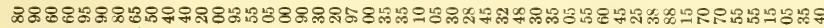

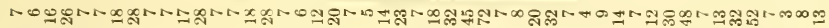

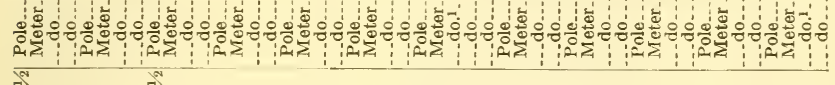

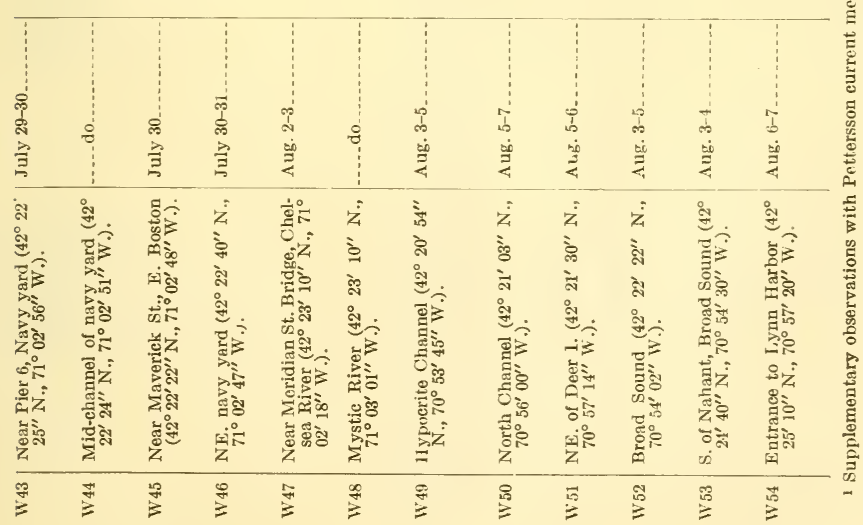

$81772-28-6$ 


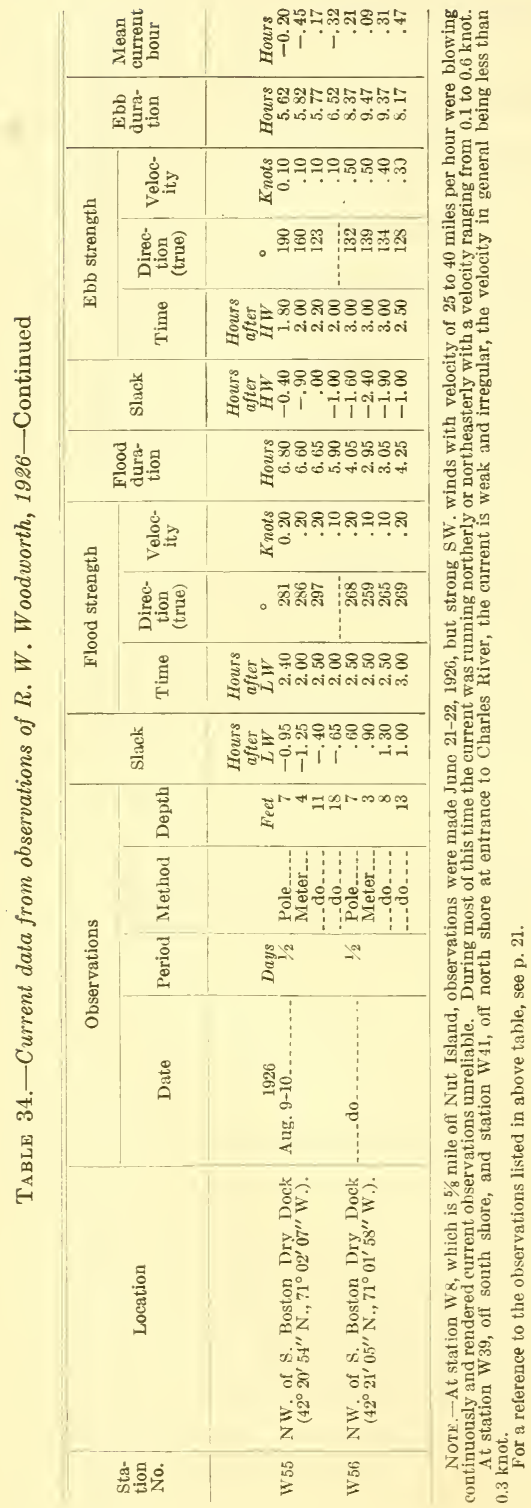


TABLE 35.-Current harmonic constants, stations W1, W16, W37

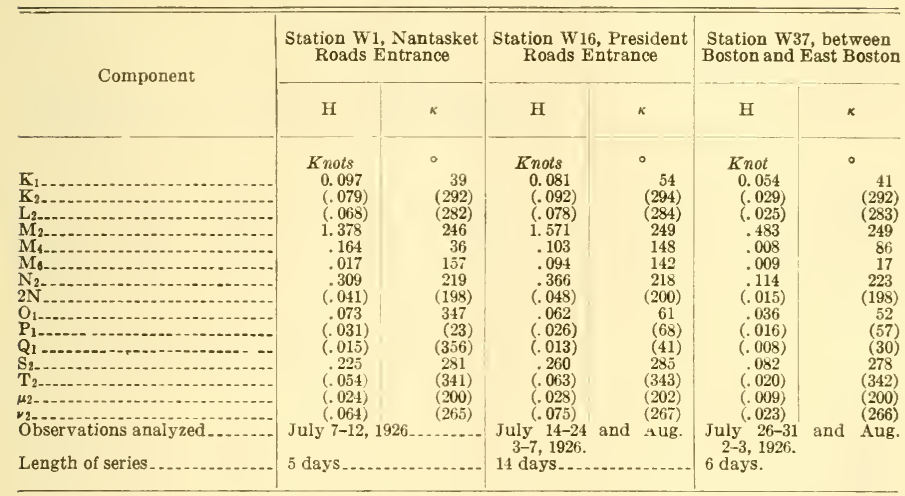

The component epochs refer to the times of flood strength of the several components. Inferred constants are in parentheses. For reference to the harmonic constants in this table, see p. 23.

TABLE 36.-Tidal currents, Boston Light Vessel

Observations Sept. 22-Dec. 26, 1913

Time referred to high water at Boston Nary Yard

High water

1 hour after high water

2 hours after high water

3 hours after high water

4 hours after high water

5 hours after high water.

6 hours after high water.

7 hours after high water

8 hours after high water

9 hours after hi water.

10 hours after hi2:: water.

11 hours after high water.

12 hours after high water.
Observations June 8, 1926-June 30, 1927

\begin{tabular}{|c|c|c|}
\hline $\begin{array}{l}\text { Time referred to high water } \\
\text { at Commonwealth Pier No. } 6\end{array}$ & Velocity & $\begin{array}{l}\text { Direction } \\
\text { (true) }\end{array}$ \\
\hline & Knot & $\circ$ \\
\hline High water & 0.03 & 75 \\
\hline $\begin{array}{l}1 \text { hour after high water } \\
2 \text { hours after high water }\end{array}$ & .06 & 84 \\
\hline $\begin{array}{l}2 \text { hours after hi } \\
3 \text { hours after hi }\end{array}$ & .09 & 88 \\
\hline 4 hours after high water... & .10 & 86 \\
\hline 5 hours after high water. & 08 & 82 \\
\hline 6 hours after high water & .03 & 93 \\
\hline 7 hours after high water.. & .01 & 210 \\
\hline 8 hours after high wat & 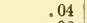 & 24 \\
\hline 9 hours after high water. & .06 & 264 \\
\hline 10 hours after high wat & .0 & 266 \\
\hline 11 hours afte & & 25 \\
\hline 12 hours after & & \\
\hline
\end{tabular}

PHASES REFERRED TO TIDES AT COMMONWEALTH PIER NO. 5

\begin{tabular}{|c|c|c|c|}
\hline & $\begin{array}{l}\text { Series, } 1913 \\
\text { (96 days) }\end{array}$ & $\begin{array}{l}\text { Series, 1926-27 } \\
\text { (388 days) }\end{array}$ & $\begin{array}{c}\text { Means, weighted } \\
\text { (484 days) }\end{array}$ \\
\hline $\begin{array}{l}\text { Slack before flood } \\
\text { Strength of flood } \\
\text { Slack before ebb } \\
\text { Strength of ebb } \\
\text { Velocity at strength of flood } \\
\text { Velocity at strength of ebb. } \\
\text { Direction at strength of flood. } \\
\text { Direction at strength of ebb. }\end{array}$ & 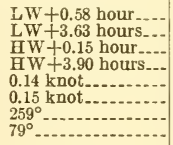 & $\begin{array}{l}\text { LW }+0.58 \text { hour...- } \\
\text { LW }+3.23 \text { hours.... } \\
\text { HW }-0.87 \text { hour } \\
\text { HW }+3.50 \text { hours... } \\
0.07 \text { knot } \\
0.10 \text { knot } \\
254^{\circ} \\
86^{\circ}\end{array}$ & $\begin{array}{l}\text { LW }+0.58 \text { hour. } \\
\text { LW+3.31 hours. } \\
\text { HW }-0.67 \text { hour. } \\
\text { HW }+3.58 \text { hours. } \\
0.08 \text { knot. } \\
0.11 \text { knot. } \\
255^{\circ} \text {. } \\
85^{\circ} \text {. }\end{array}$ \\
\hline
\end{tabular}

For reference to above table, see p. 24. 
TABLE 37.-Set of nontidal current, Boston Light Vessel

\begin{tabular}{|c|c|c|c|c|c|}
\hline \multirow[b]{2}{*}{ Month } & \multicolumn{5}{|c|}{ Observations Sept. 22-Dec. 26, 1913} \\
\hline & $\begin{array}{c}\text { North } \\
\text { (magnetic) } \\
\text { component }\end{array}$ & $\begin{array}{l}\text { East (mag- } \\
\text { netic) com- } \\
\text { ponent }\end{array}$ & $\begin{array}{l}\text { Resultant } \\
\text { velocity }\end{array}$ & $\begin{array}{c}\text { Direction } \\
\text { (magnetic) }\end{array}$ & $\begin{array}{l}\text { Direction } \\
\text { (true) }\end{array}$ \\
\hline 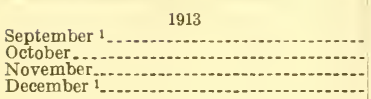 & $\begin{array}{r}K \text { not } \\
0.00 \\
-.05 \\
.05 \\
-.02\end{array}$ & $\begin{array}{r}\text { Knot } \\
0.04 \\
-.01 \\
.01 \\
.03\end{array}$ & $\begin{array}{r}\text { Knot } \\
0.04 \\
.05 \\
.05 \\
.04\end{array}$ & $\begin{array}{r}90 \\
191 \\
11 \\
124\end{array}$ & $\begin{array}{r}76 \\
177 \\
357 \\
110\end{array}$ \\
\hline \multirow[t]{2}{*}{ Series 1913 } & -.006 & .012 & .01 & 117 & 103 \\
\hline & \multicolumn{5}{|c|}{ Observations June 8, 1926-June 30,1927} \\
\hline $\begin{array}{l}\text { June }{ }^{1} \\
\text { July } \\
\text { August } \\
\text { September }\end{array}$ & $\begin{array}{r}0.00 \\
.03 \\
.00 \\
.01 \\
.00 \\
-.02 \\
-.02\end{array}$ & $\begin{array}{l}0.07 \\
.04 \\
.00 \\
.00 \\
.00 \\
.01 \\
.02\end{array}$ & $\begin{array}{l}0.07 \\
.05 \\
.00 \\
.01 \\
.00 \\
.02 \\
.03\end{array}$ & $\begin{array}{r}90 \\
53 \\
0 \\
27 \\
135\end{array}$ & $\begin{array}{r}75 \\
38 \\
345 \\
120 \\
120\end{array}$ \\
\hline $\begin{array}{l}\text { January } \\
\text { February } \\
\text { March } \\
\text { A pril } \\
\text { May } \\
\text { June }\end{array}$ & $\begin{array}{r}-.02 \\
-.03 \\
-.04 \\
-.09 \\
.02 \\
.02\end{array}$ & $\begin{array}{l}.02 \\
.00 \\
.05 \\
.05 \\
.03 \\
.00\end{array}$ & $\begin{array}{l}.03 \\
.03 \\
.06 \\
.10 \\
.04 \\
.02\end{array}$ & $\begin{array}{r}135 \\
180 \\
129 \\
151 \\
56 \\
0\end{array}$ & $\begin{array}{r}120 \\
165 \\
114 \\
136 \\
41 \\
345\end{array}$ \\
\hline Series 1926-27 $\ldots$ & -.008 & .022 & .02 & 110 & 95 \\
\hline
\end{tabular}

1 Records cover only a portion of the month.

For reference to above table, see p. 25.

TABLE 38.-Current due to wind, Boston Light Vessel

\begin{tabular}{|c|c|c|c|c|c|c|c|c|c|c|}
\hline \multirow[b]{2}{*}{$\begin{array}{l}\text { Direction from wbich } \\
\text { wind is blowing }\end{array}$} & \multicolumn{5}{|c|}{ Series Sept. 22-Dec. 26, 1913} & \multicolumn{5}{|c|}{ Series June 8, 1926-June 30, 1927} \\
\hline & $\begin{array}{l}\text { Num- } \\
\text { ber of } \\
\text { obser- } \\
\text { vations }\end{array}$ & $\begin{array}{l}\text { Aver- } \\
\text { age } \\
\text { wind } \\
\text { veloc- } \\
\text { ity per } \\
\text { hour }\end{array}$ & $\begin{array}{l}\text { Aver- } \\
\text { age cur- } \\
\text { rent ve- } \\
\text { locity }\end{array}$ & $\begin{array}{l}\text { Direc- } \\
\text { tion of } \\
\text { current }\end{array}$ & $\begin{array}{l}\text { Devia- } \\
\text { tion } \\
\text { from } \\
\text { wind } \\
\text { direc- } \\
\text { tion }\end{array}$ & $\begin{array}{l}\text { Num- } \\
\text { ber of } \\
\text { obser- } \\
\text { vations }\end{array}$ & $\begin{array}{l}\text { Aver- } \\
\text { age } \\
\text { wind } \\
\text { veloc- } \\
\text { ity per } \\
\text { hour }\end{array}$ & $\begin{array}{l}\text { Aver- } \\
\text { age cur- } \\
\text { rent ve- } \\
\text { locity }\end{array}$ & $\begin{array}{l}\text { Direc- } \\
\text { tion of } \\
\text { current }\end{array}$ & $\begin{array}{l}\text { Devia- } \\
\text { tion } \\
\text { from } \\
\text { wind } \\
\text { direc- } \\
\text { tion }\end{array}$ \\
\hline & & Miles & Knots & $\stackrel{\circ}{197}$ & & & Miles & Knots & $\circ$ & $\circ$ \\
\hline $\begin{array}{l}\text { North } \\
\text { Northeast.... }\end{array}$ & $\begin{array}{l}181 \\
161\end{array}$ & $\begin{array}{l}20.2 \\
19.2\end{array}$ & $\begin{array}{r}0.17 \\
.16\end{array}$ & $\begin{array}{l}197 \\
230\end{array}$ & $\begin{array}{r}17 \\
5\end{array}$ & $\begin{array}{l}369 \\
795\end{array}$ & $\begin{array}{l}16.1 \\
20.7\end{array}$ & $\begin{array}{r}0.08 \\
.09\end{array}$ & $\begin{array}{l}194 \\
229\end{array}$ & $\begin{array}{r}14 \\
4\end{array}$ \\
\hline East_............ & 62 & 16.9 & .14 & 278 & 8 & 322 & 15. 0 & .08 & 293 & 23 \\
\hline Southeast... & 154 & 15. 9 & .15 & 337 & 22 & 670 & 14 & .08 & 346 & 31 \\
\hline South.. & 74 & 17.3 & .19 & 16 & 16 & 528 & 13.8 & .09 & 32 & 32 \\
\hline Southwest.......... & 206 & 16.1 & .18 & 41 & -4 & 1,111 & 15.4 & .10 & 66 & 21 \\
\hline West & 202 & 18. 3 & .1 & 76 & -14 & 816 & 14. 7 & .06 & 90 & 0 \\
\hline Northwest & 222 & 20.0 & .16 & 166 & 31 & 1,642 & 19.6 & .11 & 158 & 23 \\
\hline
\end{tabular}

Maximum current observed was 1 knot on Apr. 7, 1927, with the wind blowing from the northwest with a velocity from 34 to 40 miles per hour.

For reforence to above table, see p. 25. 
TABLE 39.-Current harmonic constants, Boston Light Vessel

[From 221-day series, June 9, 1926-Jan. 15, 1927]

\begin{tabular}{|c|c|c|c|c|c|c|c|c|c|}
\hline \multirow{2}{*}{ Component } & \multicolumn{2}{|c|}{$\begin{array}{l}\text { North com- } \\
\text { ponent } \\
\text { (magnetic) }\end{array}$} & \multicolumn{2}{|c|}{$\begin{array}{l}\text { East com- } \\
\text { ponent } \\
\text { (magnetic) }\end{array}$} & \multirow{2}{*}{ Component } & \multicolumn{2}{|c|}{$\begin{array}{l}\text { North com- } \\
\text { ponent } \\
\text { (magnetic) }\end{array}$} & \multicolumn{2}{|c|}{$\begin{array}{c}\text { East com- } \\
\text { ponent } \\
\text { (magnetic) }\end{array}$} \\
\hline & $\mathrm{H}$ & $\kappa$ & H & $\kappa$ & & $\mathrm{H}$ & $\kappa$ & $\mathrm{H}$ & $\kappa$ \\
\hline $\begin{array}{l}\mathbf{K}_{1} \ldots \ldots \\
\mathbf{K}_{2} \ldots \\
M_{2} \ldots \ldots\end{array}$ & $\begin{array}{r}\text { Knot } \\
0.012 \\
.003 \\
.019 \\
.007 \\
.004\end{array}$ & $\begin{array}{l}\circ \\
111 \\
4 \\
243 \\
243 \\
250\end{array}$ & $\begin{array}{r}K n o t \\
0.019 \\
.008 \\
.080 \\
.004 \\
.003\end{array}$ & $\begin{array}{l}\circ \\
204 \\
138 \\
51 \\
219 \\
24\end{array}$ & 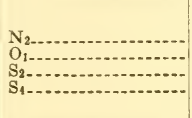 & $\begin{array}{l}\text { Knot } \\
0.007 \\
.008 \\
.004 \\
.001\end{array}$ & \begin{tabular}{r}
\multicolumn{1}{l}{} \\
313 \\
78 \\
204 \\
228
\end{tabular} & $\begin{array}{r}\text { Knot } \\
.019 \\
.017 \\
.017 \\
.004\end{array}$ & $\begin{array}{r}27 \\
256 \\
90 \\
294\end{array}$ \\
\hline
\end{tabular}

For reference to above table, see p. 25. 


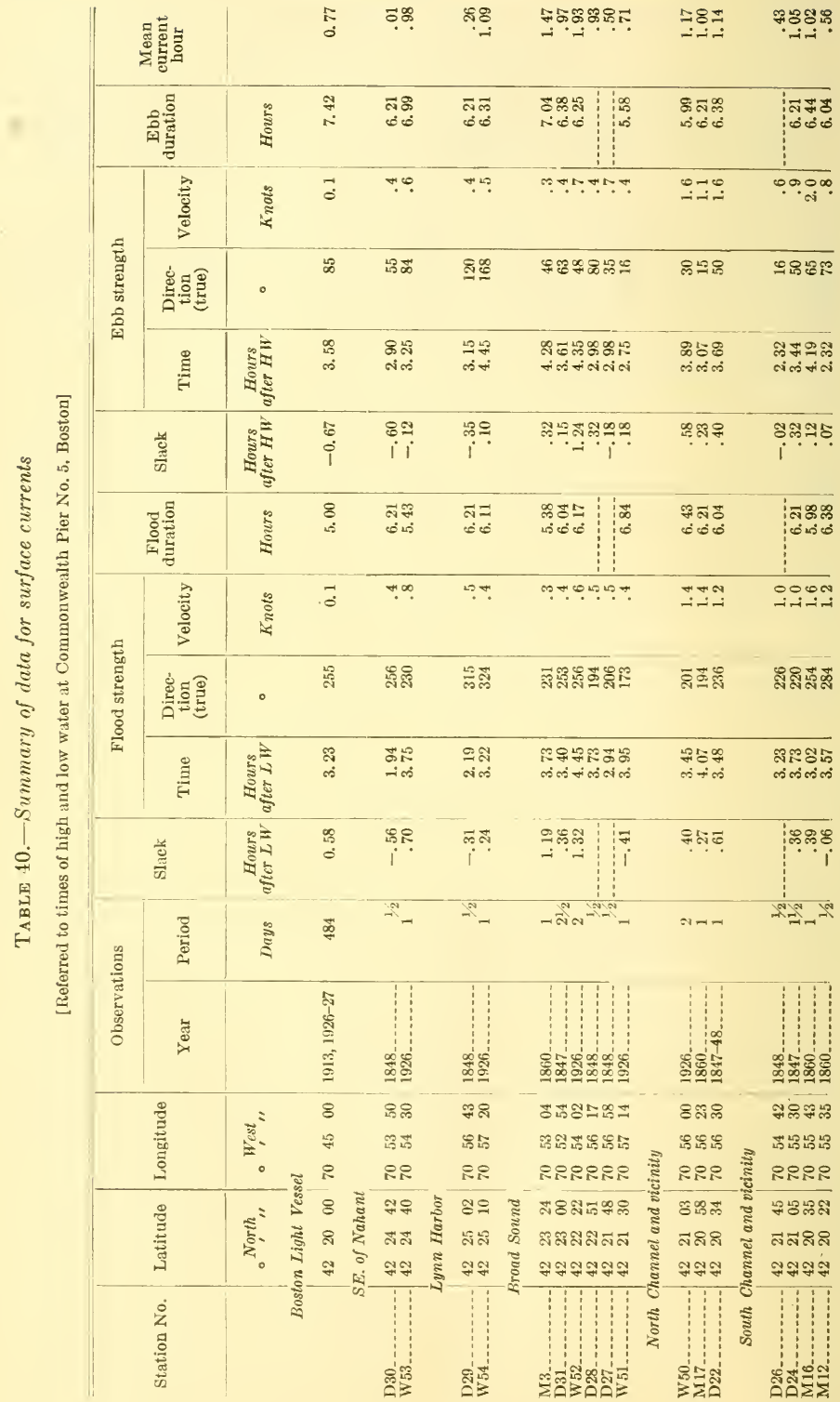


TIDES AND CURRENTS IN BOSTON HARBOR

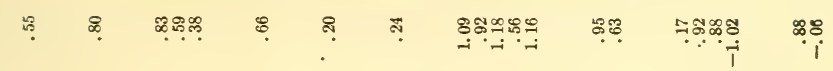

\begin{tabular}{|c|c|c|c|c|c|c|c|c|c|}
\hline 岕 & ה & 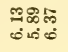 & $\begin{array}{l}\mathscr{A} \\
6\end{array}$ & స్ & 萿 & 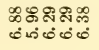 & $\begin{array}{l}\text { \&ิส } \\
\text { ஸें }\end{array}$ & 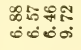 & 85 \\
\hline$\therefore$ & $?$ & 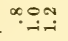 & 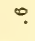 & $\because$ & $\because$ & Nifini:. & $\underset{\text { NM }}{\text { Nก }}$ & m-mo & $\stackrel{0}{-\infty}$ \\
\hline
\end{tabular}

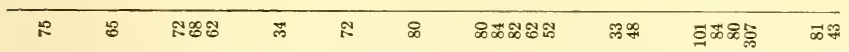

\begin{tabular}{|c|c|c|c|}
\hline $\begin{array}{l}\mathscr{8} \\
\text { is }\end{array}$ & & & \\
\hline
\end{tabular}

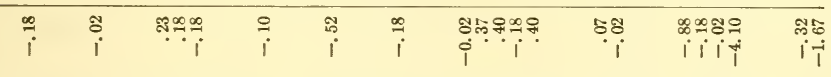

\begin{tabular}{|c|c|c|c|c|c|c|c|c|c|}
\hline $\begin{array}{l}\infty \\
\infty \\
\infty\end{array}$ & E & 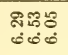 & $\frac{m}{6}$ & $\begin{array}{l}\overrightarrow{\text { जे }} \\
\text { ல }\end{array}$ & $\begin{array}{l}\infty \\
\infty \\
0\end{array}$ & 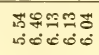 & $\begin{array}{l}\cong \pi \\
\oplus 0 \\
0\end{array}$ & 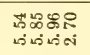 & $\begin{array}{l}\infty=7 \\
\text { in }\end{array}$ \\
\hline$\because$ & $\because$ & 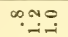 & $\stackrel{i}{i}$ & $\exists$ & $\varphi$ & "- & iti & оำ & $\stackrel{+\infty}{\pi}$ \\
\hline
\end{tabular}

๕ ๕

\begin{tabular}{|c|c|c|c|c|c|c|c|c|}
\hline$\stackrel{\mathscr{m}}{\dot{m}}$ & $\stackrel{\infty}{\stackrel{\infty}{\infty}}$ & 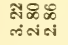 & $\stackrel{9}{m}$ & $\begin{array}{l}\vec{S} \\
\text { i }\end{array}$ & $\stackrel{9}{\stackrel{1}{\circ}}$ & 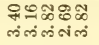 & 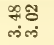 & 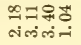 \\
\hline
\end{tabular}

\begin{tabular}{|c|c|c|c|c|c|c|c|c|c|}
\hline$\because$ & ชิ & 워용 & 웅 & $\stackrel{\infty}{i}$ & $\vec{\infty}$ & ๑ุษ & 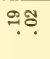 & 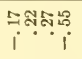 & $7 \div$ \\
\hline$-\infty$ & $=$ & $-\infty=$ & $-x^{\infty}$ & -1 & $-\infty$ & $-\infty-\pi$ & $\approx$ & & - \\
\hline
\end{tabular}

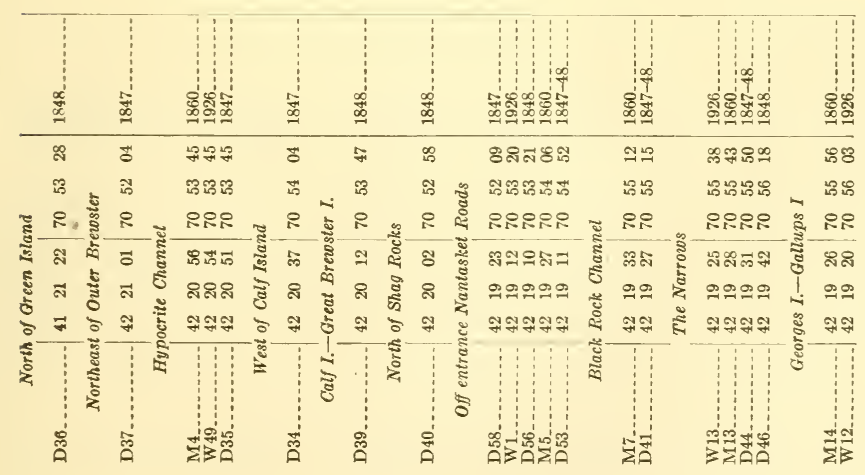




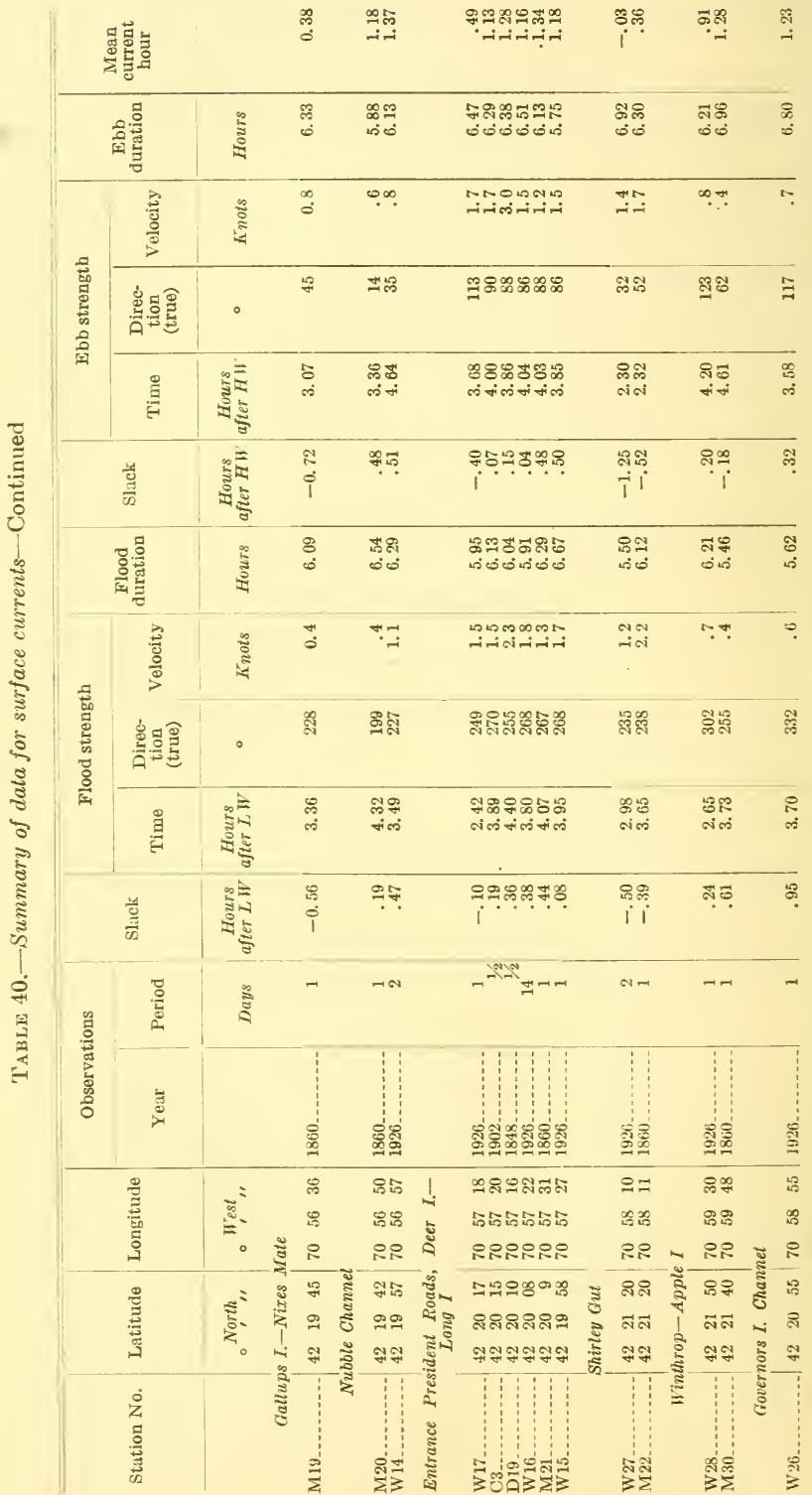


TIDES AND CURRENTS IN BOSTON HARBOR

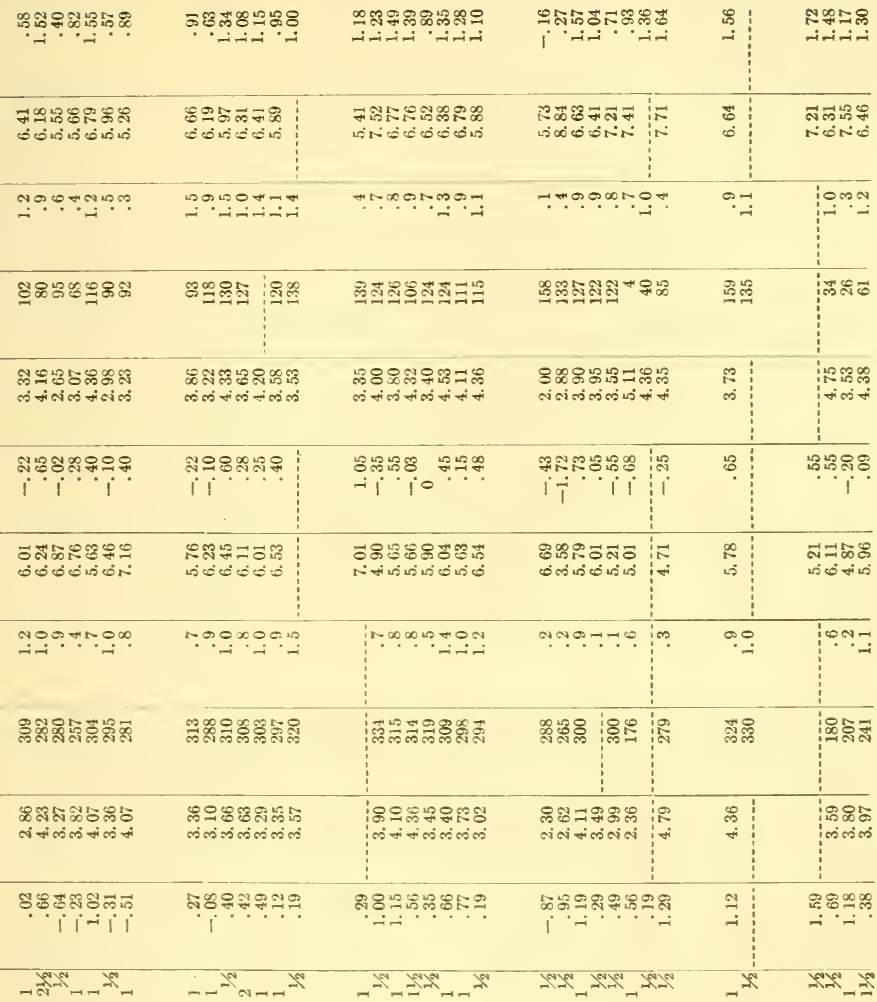

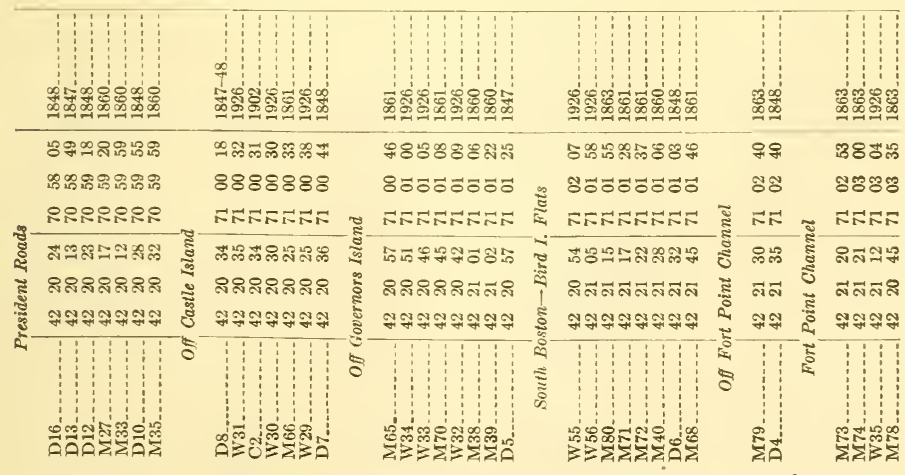




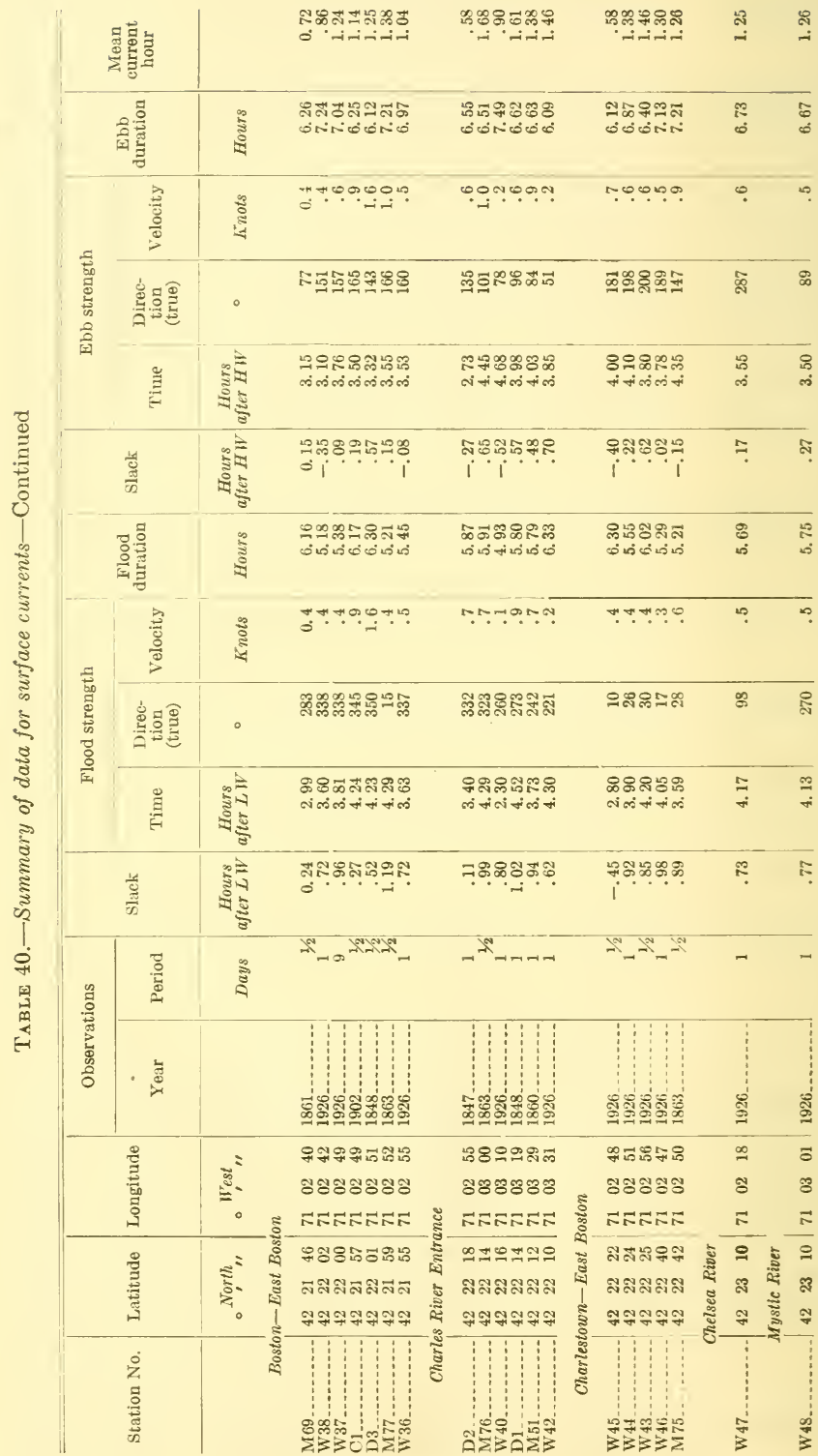


TIDES AND CURRENTS IN BOSTON HARBOR

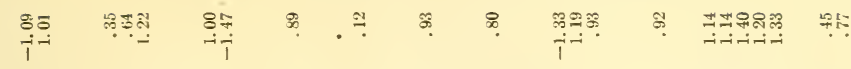

\begin{tabular}{|c|c|c|c|c|c|c|c|c|c|c|}
\hline 8 & $\begin{array}{l}\text { fक्ष } \\
\text { fisio }\end{array}$ & $\begin{array}{l}9 \pi \\
0.5 \\
0 \leqslant\end{array}$ & $\stackrel{9}{9}$ & $\stackrel{?}{?}$ & $\stackrel{2}{3}$ & సี & 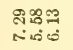 & $\begin{array}{l}\infty \\
\infty \\
0\end{array}$ & 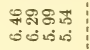 & S: \\
\hline 010 & $\because \infty ?$ & $?$ & $\infty$. & ?? & ?. & $\because$ & $\because$ & $\stackrel{\circ}{-}$ & 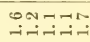 & $\begin{array}{l}\text { mo } \\
\text { जimi }\end{array}$ \\
\hline
\end{tabular}

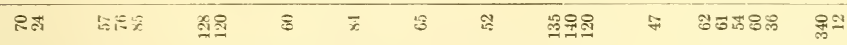

蛋

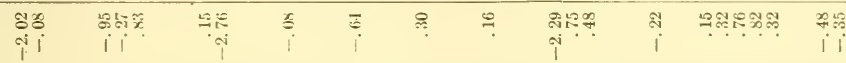

\begin{tabular}{|c|c|c|c|c|c|c|c|c|c|c|}
\hline \begin{tabular}{l}
9 \\
\hdashline \\
\end{tabular} & 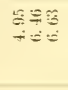 & 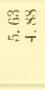 & s: & ह & 今 & $\begin{array}{l}\vec{a} \\
\vdots \\
0\end{array}$ & 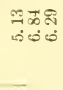 & $\begin{array}{l}180 \\
150 \\
150\end{array}$ & 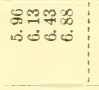 & $\begin{array}{l}\text { RA } \\
\text { is is }\end{array}$ \\
\hline$\because$ & $\because$ & $\because \cong$ & 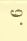 & $\div$ & $\cong$ & $\Leftrightarrow$ & †? & & $\begin{array}{l}m \infty \\
\text { - }\end{array}$ & $\overrightarrow{\text { sici }}$ \\
\hline
\end{tabular}

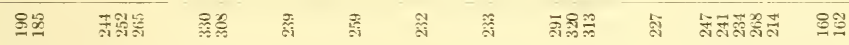

\begin{tabular}{|c|c|c|c|c|c|c|c|c|c|c|}
\hline $\begin{array}{l}\text { 싱요 } \\
\text { sin }\end{array}$ & 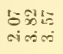 & $\begin{array}{ll}1 \\
t a t\end{array}$ & ๙ิ่ & $\underset{\text { iे }}{\text { sे }}$ & $\frac{x}{\infty}$ & $\begin{array}{l}\text { i⿱ } \\
\text { is }\end{array}$ & 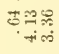 & 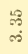 & 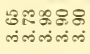 & 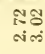 \\
\hline ? & 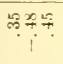 & 淃 & ร & $\mathscr{?}$ & की & ฉิ & $\begin{array}{l}\beth 0 \div \\
i\end{array}$ & \& & 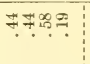 & 중욕 \\
\hline$\therefore-$ & $-\therefore$ & $-\infty$ & - & - & - & - & $a^{s}-$ & N & $-7-4=-2$ & $\mathrm{Cl}^{-5}$ \\
\hline
\end{tabular}

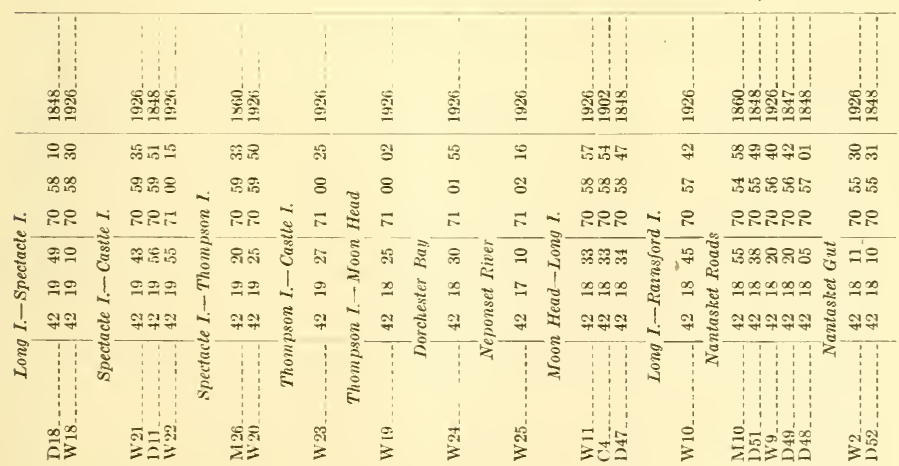




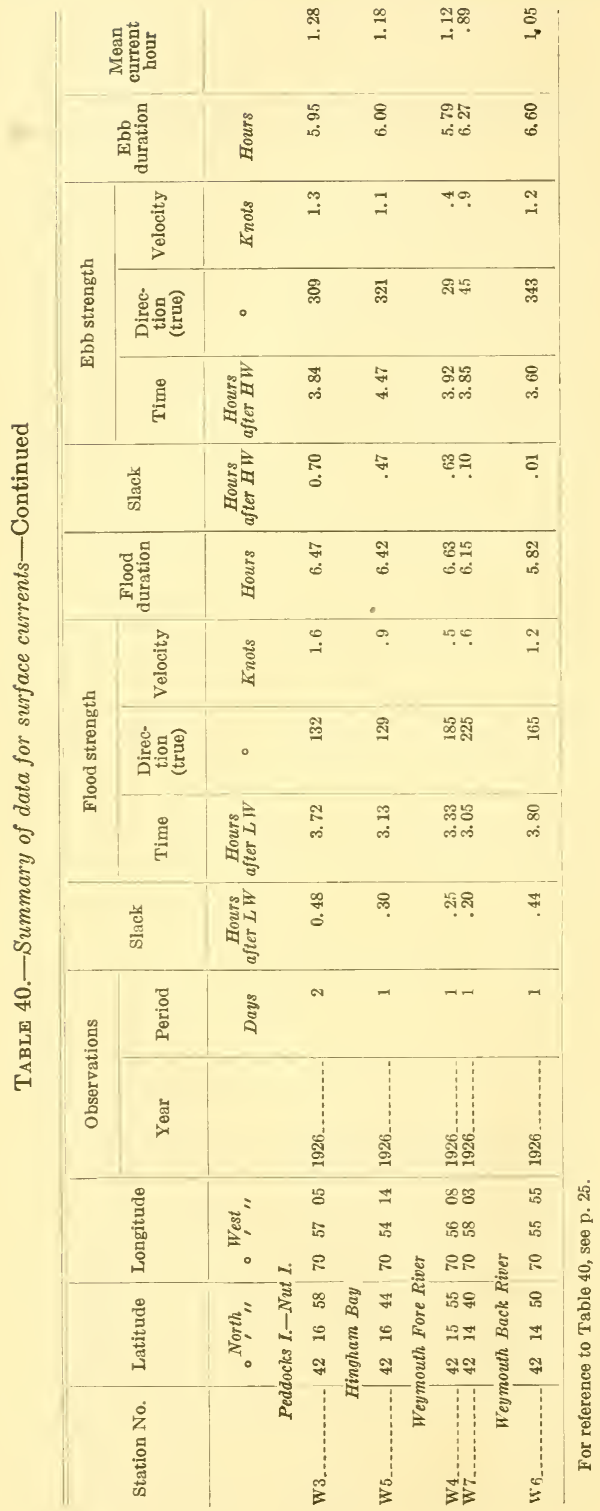


TABLE 41.-Condensed current data for selected localities

[Time differences refer to currents off Deer Island Light in President Roads Entrance]

\begin{tabular}{|c|c|c|c|c|c|c|c|c|c|c|c|c|}
\hline \multirow{2}{*}{ Location } & \multirow{2}{*}{\multicolumn{2}{|c|}{$\begin{array}{l}\text { Lati- } \\
\text { tude }\end{array}$}} & \multirow{2}{*}{\multicolumn{2}{|c|}{$\begin{array}{l}\text { Longi- } \\
\text { tude }\end{array}$}} & \multirow{2}{*}{\multicolumn{2}{|c|}{$\begin{array}{l}\text { Time } \\
\text { differ- } \\
\text { ence }\end{array}$}} & \multicolumn{3}{|c|}{$\begin{array}{l}\text { Strength of } \\
\text { flood }\end{array}$} & \multirow{2}{*}{$\begin{array}{c}\text { Flood } \\
\text { velocity }\end{array}$} & \multirow{2}{*}{$\begin{array}{c}\mathrm{Ebb} \\
\text { velocity }\end{array}$} & \multirow{2}{*}{ Basis of data } \\
\hline & & & & & & & $\underset{\nabla}{\text { Int }}$ & & $\begin{array}{l}\text { Direc- } \\
\text { tion }\end{array}$ & & & \\
\hline & \multicolumn{2}{|c|}{$\underset{0}{\text { North }}$} & \multicolumn{2}{|c|}{ West } & \multicolumn{2}{|c|}{ H. $m}$. & \multicolumn{2}{|c|}{ H. $m}$. & $\bullet$ & Knots & \multirow{4}{*}{$\begin{array}{r}\text { Knots } \\
0.1 \\
.6 \\
.5\end{array}$} & \multirow{4}{*}{$\begin{array}{l}\text { Current stations } \\
\text { Light vessel. } \\
\text { D30, W53. } \\
\text { W54. }\end{array}$} \\
\hline Boston Light Vessel........... & & & 70 & 45 & -0 & & 8 & & 255 & 0.1 & & \\
\hline Nahant (off East Point) & & 25 & & 55 & -0 & 25 & & 20 & 235 & .7 & & \\
\hline $\begin{array}{l}\text { Lynn Harbor Entrance.... } \\
\text { North Channel (off Great }\end{array}$ & & 25 & 70 & 57 & -0 & & & 15 & 325 & 4 & & \\
\hline $\begin{array}{l}\text { North Cuannei (on Grear } \\
\text { Faun) }\end{array}$ & 42 & 21 & 70 & 56 & 0 & 00 & 8 & 30 & 200 & 1. 4 & 1. 6 & W50. \\
\hline Hypocrite Channel & 42 & 21 & 70 & 54 & -0 & 35 & 7 & 50 & 255 & 1.2 & 1. 0 & W 49. \\
\hline Nantasket Roads Entrance. & 42 & & 70 & 53 & -0 & 15 & 8 & 15 & 260 & 1.5 & 1.5 & W1. \\
\hline Black Rock Channel........ & & & 70 & 55 & -0 & 20 & 8 & 20 & 220 & 1. 2 & 1.2 & M17, D41. \\
\hline The Narrows (off Georges I.) & 42 & 19 & 70 & 56 & -0 & 30 & 7 & 55 & 270 & 1.2 & 1.2 & W13, M13, D44. \\
\hline The Narrows (off Gallups I.) & 42 & & 70 & 56 & $(1$ & & 6 & 05 & 135 & .4 & 1.0 & D46. \\
\hline $\begin{array}{l}\text { Between Gallups I. and } \\
\text { Georges I }\end{array}$ & 42 & 19 & 70 & 56 & -0 & & 7 & 35 & 260 & 1.0 & .9 & M14, W12. \\
\hline $\begin{array}{l}\text { Between Gallups I. and } \\
\text { Nixes Mate. }\end{array}$ & 42 & 20 & 70 & 57 & -0 & 45 & 8 & 25 & 230 & $\begin{array}{r}1.0 \\
.4\end{array}$ & .8 & M19. \\
\hline Nubble Channel. & 42 & 20 & 70 & 57 & +0 & 05 & 8 & 55 & 195 & .8 & .7 & M20, W14. \\
\hline $\begin{array}{l}\text { President Roads Entrance } \\
\text { (off Deer I. Light). }\end{array}$ & 42 & 20 & 70 & 57 & 0 & 00 & 8 & 50 & 270 & 1.8 & 1.5 & W 16. \\
\hline Shirley Gut. & 42 & 21 & 70 & 58 & -1 & 00 & 8 & 20 & 235 & 1.5 & 1. 5 & W27, M22. \\
\hline Off Winthrop ( 1 mile south). & 42 & 22 & 70 & 59 & -0 & 15 & 7 & 45 & 300 & .7 & .8 & W 28 . \\
\hline $\begin{array}{l}\text { Governors I. Channel (en- } \\
\text { trance.) }\end{array}$ & 42 & 21 & 70 & 59 & +0 & 05 & 8 & 45 & 330 & .6 & .7 & W26. \\
\hline $\begin{array}{l}\text { Main ship channel (off } \\
\text { Castle I.). }\end{array}$ & 42 & 20 & 71 & 01 & 0 & 00 & 8 & 50 & 315 & 1. 0 & 1.1 & W30, D7, W33. \\
\hline $\begin{array}{l}\text { Fort Point Channel En- } \\
\text { trance. }\end{array}$ & 42 & 21 & 71 & 03 & 0 & 00 & 8 & 50 & 205 & .2 & .3 & W35. \\
\hline $\begin{array}{l}\text { Between Boston and E. } \\
\text { Boston. }\end{array}$ & 42 & 22 & 71 & 03 & +0 & 05 & 8 & 50 & 340 & .4 & .6 & W37. \\
\hline Off Navy Yard, Boston .... & 42 & 22 & 71 & 03 & +0 & 10 & 9 & 00 & 25 & .4 & .6 & W44, W46. \\
\hline Chelsea River Entrance..... & 42 & 23 & 71 & 02 & +0 & 10 & 9 & 10 & 100 & .5 & .6 & W47. \\
\hline Mystic River Entrance..... & 42 & 23 & 71 & 03 & +0 & 10 & 9 & 10 & 270 & .5 & .5 & W48. \\
\hline $\begin{array}{l}\text { Between Long I. and Spec- } \\
\text { tacle I. }\end{array}$ & 42 & 19 & 70 & 58 & -0 & 10 & 8 & 35 & 185 & .4 & .5 & W18. \\
\hline $\begin{array}{l}\text { Between Spectacle I. and } \\
\text { Castle I. }\end{array}$ & 42 & 20 & 71 & 00 & -0 & 25 & 8 & 15 & 250 & .8 & .8 & D11, W21, W22. \\
\hline $\begin{array}{l}\text { Between Spectacle I. and } \\
\text { Thompson I. }\end{array}$ & 42 & 19 & 71 & 00 & -2 & 40 & 5 & 40 & 310 & .3 & .5 & W20. \\
\hline $\begin{array}{l}\text { Between Thompson I. and } \\
\text { Castle I. }\end{array}$ & 42 & 19 & 71 & 00 & -0 & 15 & 8 & 15 & 240 & .6 & .8 & W23. \\
\hline $\begin{array}{l}\text { Between Thompson I. and } \\
\text { Moon Head. }\end{array}$ & 42 & 18 & 71 & 00 & -1 & 00 & 7 & 45 & 260 & .4 & .5 & W19. \\
\hline $\begin{array}{l}\text { Dorchester Bay (off Thim- } \\
\text { ble I.). }\end{array}$ & 42 & 18 & 71 & 02 & -0 & 15 & 8 & 15 & 230 & .8 & .9 & W24. \\
\hline $\begin{array}{l}\text { Neponset River (N. Y., N. } \\
\text { H. \& H. R. R. bridge). }\end{array}$ & 42 & 17 & 71 & 02 & -0 & 25 & 7 & 50 & 230 & .6 & .7 & W25. \\
\hline $\begin{array}{l}\text { Between Moon Head and } \\
\text { Long I. }\end{array}$ & 42 & 19 & 70 & 59 & -2 & 30 & 5 & 40 & 310 & .4 & .4 & W11. \\
\hline $\begin{array}{l}\text { Between Long I. and Rains- } \\
\text { ford I. }\end{array}$ & 42 & 19 & 70 & 58 & -0 & 15 & 8 & 25 & 225 & .8 & 1.0 & W10. \\
\hline $\begin{array}{l}\text { Nantasket Roads (off } \\
\text { Georges I.). }\end{array}$ & 42 & 19 & 70 & 55 & 0 & 00 & 8 & 45 & 245 & 1.5 & 1.5 & M10, D51. \\
\hline $\begin{array}{l}\text { Nantasket Roads (off Rains- } \\
\text { ford I.). }\end{array}$ & 42 & 18 & 70 & 57 & +0 & 10 & 9 & 00 & 240 & 1. 2 & 1.3 & D48, D49, W9. \\
\hline Nantasket Gut............... & 42 & 18 & 70 & 56 & -0 & 35 & 7 & 55 & 160 & 2.3 & 2.6 & W2, D52. \\
\hline $\begin{array}{l}\text { Between Peddocks I. and } \\
\text { Nut I. }\end{array}$ & 42 & 17 & 70 & 57 & +0 & 05 & 8 & 45 & 130 & 1. 6 & 1.3 & W3. \\
\hline $\begin{array}{l}\text { Hingham Bay (off Bumkin } \\
\text { I.). }\end{array}$ & 42 & 16 & 70 & 54 & 0 & 00 & 8 & 10 & 130 & .9 & 1.1 & W5. \\
\hline $\begin{array}{l}\text { Weymouth Fore River En- } \\
\text { trance. }\end{array}$ & 42 & 16 & 70 & 56 & 0 & 00 & 8 & 25 & 185 & .5 & .4 & W4. \\
\hline $\begin{array}{l}\text { Weymouth Fore River } \\
\text { (Quincy Pt. Bridge). }\end{array}$ & 42 & 15 & 70 & 58 & -0 & 15 & 8 & 05 & 225 & .6 & .9 & W7. \\
\hline $\begin{array}{l}\text { Weymouth Back River } \\
\text { (drawbridge). }\end{array}$ & 42 & 15 & 70 & 56 & -0 & 05 & 8 & 50 & 165 & 1. 2 & 1.2 & W6. \\
\hline
\end{tabular}

1 Current irregular between Gallups Island and Lovell Island. See p. 26.

For reference to Table 41 , see p. 27. 
TABLE 42.-Temperature and density of sea water, Boston Navy Yard, 1863

\begin{tabular}{|c|c|c|c|c|c|c|}
\hline \multirow{2}{*}{ Month } & \multicolumn{3}{|c|}{ Temperature, ${ }^{\circ} \mathrm{C}$. } & \multicolumn{3}{|c|}{ Density at $15^{\circ} \mathrm{C}$} \\
\hline & Mean & Warmest & Coldest & Mean & Heaviest & Lightest \\
\hline $\begin{array}{l}\text { February } \\
\text { March } \\
\text { A pril } \\
\text { May } \\
\text { June } \\
\text { July } \\
\text { August } \\
\text { September } \\
\text { October } \\
\text { November } \\
\text { December }\end{array}$ & $\begin{array}{r}0.1 \\
.5 \\
5.9 \\
11.5 \\
14.1 \\
18.2 \\
18.2 \\
16.4 \\
12.6 \\
7.7 \\
1.3\end{array}$ & $\begin{array}{r}1.4 \\
3.3 \\
10.6 \\
17.8 \\
19.4 \\
22.8 \\
22.8 \\
19.4 \\
15.0 \\
8.9 \\
5.0\end{array}$ & $\begin{array}{r}-1.1 \\
-.6 \\
1.9 \\
6.9 \\
9.4 \\
15.0 \\
15.0 \\
12.8 \\
5.6 \\
5.6 \\
-1.1\end{array}$ & $\begin{array}{l}1.0203 \\
1.0201 \\
1.0173 \\
1.0186 \\
1.0224 \\
1.0215 \\
1.0205 \\
1.0206 \\
1.0205 \\
1.0194 \\
1.0188\end{array}$ & $\begin{array}{l}1.0239 \\
1.0236 \\
1.0224 \\
1.0215 \\
1.0242 \\
1.0251 \\
1.0227 \\
1.0235 \\
1.0223 \\
1.0221 \\
1.0207\end{array}$ & $\begin{array}{l}1.0163 \\
1.0127 \\
1.0123 \\
1.0133 \\
1.0197 \\
1.0143 \\
1.0168 \\
1.0181 \\
1.0182 \\
1.0132 \\
1.0168\end{array}$ \\
\hline Means and extremes................ & 9.7 & 22.8 & -1.1 & 1.0200 & 1. 0251 & 1. 0123 \\
\hline
\end{tabular}

For reference to above table, see p. 28.

TABLE 43.- Temperature and density of sea water, Commonwealth Pier No. 5, 1921-1926

\begin{tabular}{|c|c|c|c|c|c|c|}
\hline \multirow{2}{*}{ Month } & \multicolumn{3}{|c|}{ Temperature, ${ }^{\circ} \mathrm{C}$. } & \multicolumn{3}{|c|}{ Density at $15^{\circ} \mathrm{C}$. } \\
\hline & Mean & Warmest & Coldest & Mean & Heaviest & Lightest \\
\hline 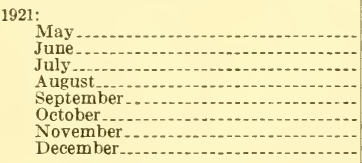 & $\begin{array}{r}12.9 \\
15.8 \\
19.4 \\
17.0 \\
17.7 \\
11.4 \\
7.0 \\
2.6\end{array}$ & \begin{tabular}{r|}
16.2 \\
19.0 \\
22.0 \\
19.2 \\
19.5 \\
14.0 \\
9.8 \\
5.0
\end{tabular} & $\begin{array}{r}10.0 \\
13.2 \\
16.5 \\
15.0 \\
15.2 \\
9.0 \\
4.2 \\
-.5\end{array}$ & $\begin{array}{l}1.0188 \\
1.0224 \\
1.0193 \\
1.0220 \\
1.0232 \\
1.0234 \\
1.0225 \\
1.0217\end{array}$ & $\begin{array}{l}1.0208 \\
1.0231 \\
1.0218 \\
1.0230 \\
1.0235 \\
1.0239 \\
1.0237 \\
1.0228\end{array}$ & $\begin{array}{l}\text { 1. } 0131 \\
1.0196 \\
1.0124 \\
1.0202 \\
1.0228 \\
1.0229 \\
1.0182 \\
1.0201\end{array}$ \\
\hline Means and extremes................... & 13.0 & 22.0 & -.5 & 1. 0217 & 1. 0239 & 1. 0124 \\
\hline $\begin{array}{l}\text { 1922: } \\
\text { January } \\
\text { February } \\
\text { March } \\
\text { April } \\
\text { May } \\
\text { June } \\
\text { July } \\
\text { August } \\
\text { September } \\
\text { October } \\
\text { November } \\
\text { December }\end{array}$ & $\begin{array}{r}-.4 \\
3.3 \\
6.7 \\
12.4 \\
15.6 \\
18.0 \\
18.1 \\
16.4 \\
12.5 \\
7.0 \\
2.1\end{array}$ & $\begin{array}{r}.8 \\
2.0 \\
5.5 \\
8.5 \\
17.0 \\
18.5 \\
21.0 \\
21.2 \\
18.8 \\
16.2 \\
8.5 \\
4.5\end{array}$ & $\begin{array}{r}-1.5 \\
-1.0 \\
-.8 \\
3.5 \\
8.0 \\
13.5 \\
16.2 \\
16.8 \\
14.2 \\
8.0 \\
4.2 \\
-.2\end{array}$ & $\begin{array}{l}1.0228 \\
1.0227 \\
1.0206 \\
1.0206 \\
1.0204 \\
1.0199 \\
1.0194 \\
1.0220 \\
1.0214 \\
1.0225 \\
1.0228 \\
1.0230\end{array}$ & $\begin{array}{l}\text { 1. } 0233 \\
1.0236 \\
1.0229 \\
1.0222 \\
1.0223 \\
1.0231 \\
1.0222 \\
1.0230 \\
1.0222 \\
1.0232 \\
1.0232 \\
1.0232\end{array}$ & $\begin{array}{l}1.0211 \\
1.0204 \\
1.0157 \\
1.0185 \\
1.0163 \\
1.0128 \\
1.0161 \\
1.0189 \\
1.0199 \\
1.0219 \\
1.0220 \\
1.0224\end{array}$ \\
\hline Means and extremes & 9.3 & 21.2 & -1.5 & 1.0215 & 1.0236 & 1. 0128 \\
\hline $\begin{array}{l}\text { January } \\
\text { February } \\
\text { March } \\
\text { April } \\
\text { May } \\
\text { June } \\
\text { July } \\
\text { August } \\
\text { September } \\
\text { October } \\
\text { November } \\
\text { December }\end{array}$ & $\begin{array}{r}-.3 \\
-1.0 \\
.6 \\
4.8 \\
10.6 \\
15.8 \\
16.1 \\
16.4 \\
16.4 \\
12.9 \\
8.7 \\
5.8\end{array}$ & $\begin{array}{r}1.0 \\
.2 \\
3.0 \\
9.0 \\
13.5 \\
19.0 \\
18.8 \\
20.0 \\
17.5 \\
15.2 \\
11.0 \\
7.8\end{array}$ & $\begin{array}{r}-1.2 \\
-1.5 \\
-1.0 \\
.0 \\
8.8 \\
13.0 \\
14.0 \\
13.2 \\
15.5 \\
11.0 \\
6.5 \\
3.2\end{array}$ & $\begin{array}{l}1.0211 \\
1.0219 \\
1.0204 \\
1.0197 \\
1.0204 \\
1.0219 \\
1.0224 \\
1.0227 \\
1.0230 \\
1.0229 \\
1.0225 \\
1.0209\end{array}$ & $\begin{array}{l}1.0224 \\
1.0228 \\
1.0225 \\
1.0215 \\
1.0222 \\
1.0225 \\
1.0230 \\
1.0232 \\
1.0234 \\
1.0234 \\
1.0232 \\
1.0222\end{array}$ & $\begin{array}{l}1.0198 \\
1.0209 \\
1.0160 \\
1.0140 \\
1.0178 \\
1.0210 \\
1,0216 \\
1.0221 \\
1.0227 \\
1.0220 \\
1.0216 \\
1.0176\end{array}$ \\
\hline Means and extremes . . . . . . . . & 8.9 & 20.0 & -1.5 & 1.0216 & 1.0234 & 1.0140 \\
\hline
\end{tabular}


TABLE 43.-Temperature and density of sea water, Commonwealth Pier No. 5, 1921-1926-Continued

\begin{tabular}{|c|c|c|c|c|c|c|}
\hline \multirow{2}{*}{. Month } & \multicolumn{3}{|c|}{ Temperature, ${ }^{\circ} \mathrm{C}$. } & \multicolumn{3}{|c|}{ Density at $15^{\circ} \mathrm{C}$. } \\
\hline & Mean & Warmest & Coldest & Mean & Heaviest & Lightest \\
\hline \multicolumn{7}{|l|}{ 1924: } \\
\hline January.... & 1.9 & 3.5 & -0.5 & 1.0213 & 1.0224 & 1. 0194 \\
\hline February & -.2 & .5 & -1.0 & 1.0220 & 1. 0228 & 1. 0209 \\
\hline March & 2,1 & 4.5 & & 1.0211 & 1. 0226 & 1. 0175 \\
\hline April-... & 6.1 & 8.8 & 3. 2 & 1. 0197 & 1. 0216 & 1. 0160 \\
\hline May & 9.5 & 11.0 & 8. 2 & 1. 0201 & 1. 0217 & 1. 0171 \\
\hline June & 13.9 & 18.8 & 10.0 & 1.0218 & 1. 0222 & 1.0208 \\
\hline July & 16.6 & 18.8 & 14.5 & 1. 0224 & 1. 0229 & 1. 0218 \\
\hline - & 17.3 & 20.0 & 15. 2 & 1. 0223 & 1. 0230 & 1. 0212 \\
\hline September & 15.8 & 19.0 & 12.8 & 1. 0212 & 1. 0223 & 1.0189 \\
\hline October & 11.8 & 15.0 & 9.8 & 1. 0223 & 1. 0229 & 1. 0214 \\
\hline November. & 8.1 & 11.5 & 5. 2 & 1. 0227 & 1. 0231 & 1. 0223 \\
\hline December.... & 2.6 & 4.5 & -.5 & 1.0229 & 1.0234 & 1.0225 \\
\hline Means and extremes..................... & 8.8 & 20.0 & -1.0 & 1.0216 & 1.0234 & 1. 0160 \\
\hline \multicolumn{7}{|l|}{ 925: } \\
\hline $\begin{array}{l}\text { January. } \\
\text { February }\end{array}$ & -1.0 & -.2 & -1.8 & 1.0229 & 1. 0237 & 1.0202 \\
\hline $\begin{array}{l}\text { February } \\
\text { March }\end{array}$ & $\begin{array}{l}1.1 \\
3.5\end{array}$ & $\begin{array}{l}2.7 \\
6.0\end{array}$ & $\begin{array}{r}-1.2 \\
1.0\end{array}$ & 214 & 230 & 1.0170 \\
\hline April..... & 7.7 & $\begin{array}{r}6.0 \\
10.0\end{array}$ & $\begin{array}{l}1.0 \\
6.5\end{array}$ & $\begin{array}{l}1.0208 \\
1.0207\end{array}$ & $\begin{array}{l}\text { 1. } 0229 \\
1.0221\end{array}$ & $\begin{array}{l}\text { 1. } 0177 \\
1.0174\end{array}$ \\
\hline May & 10.8 & 12.5 & 8.8 & 1.0220 & 1.0226 & 1. 0213 \\
\hline June. & 15.8 & 18.5 & 13.5 & 1.0225 & 1. 0231 & 1. 0211 \\
\hline July & 17.2 & 19.2 & 15. 2 & 1. 0230 & 1.0233 & 1. 0217 \\
\hline August_........ & 19.2 & 21.2 & 17.8 & 1.0229 & 1.0233 & 1.0220 \\
\hline September. & $17 . \overline{3}$ & 20.5 & 14. 2 & 1. 0228 & 1.0233 & 1. 0218 \\
\hline October & 11.0 & 14.2 & 7.5 & 1. 0231 & 1. 0233 & 1.0227 \\
\hline November......... & 7. 0 & 8.5 & 4. 2 & 1. 0227 & 1. 0230 & 1.0220 \\
\hline 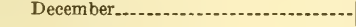 & 3.7 & 6.5 & & 1.0217 & 1. 0232 & 1.0167 \\
\hline Means and extremes........... & 9.4 & 21.2 & -1.8 & 1.0222 & 1.0237 & 1. 0167 \\
\hline \multicolumn{7}{|l|}{ 1926: } \\
\hline $\begin{array}{l}\text { January } \\
\text { February }\end{array}$ & & 2.3 & -1.3 & 1. 0225 & 1. 0234 & 1.0213 \\
\hline $\begin{array}{l}\text { February } \\
\text { March }\end{array}$ & -.5 & 1.5 & -1.5 & 1.0224 & 1.0231 & 1.0215 \\
\hline $\begin{array}{l}\text { March } \\
\text { A pril }\end{array}$ & $\begin{array}{l}1.2 \\
4.4\end{array}$ & $\begin{array}{l}2.8 \\
7.0\end{array}$ & $\begin{array}{r}-.3 \\
2.5\end{array}$ & $\begin{array}{l}1.0209 \\
1.0210\end{array}$ & $\begin{array}{l}\text { 1. } 0223 \\
1.0226\end{array}$ & $\begin{array}{l}1.0170 \\
1.0165\end{array}$ \\
\hline 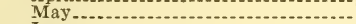 & 9.8 & 11.8 & 6.7 & 1.0215 & 1.0228 & 1. 0191 \\
\hline (n) & 14. 0 & 17. 3 & 11. 2 & 1. 0226 & 1. 0232 & 1.0212 \\
\hline July & 17.7 & 21.3 & 15.2 & 1.0230 & 1. 0234 & 1. 0214 \\
\hline August & 19.6 & 21.0 & 17.5 & 1.0226 & 1.0229 & 1. 0221 \\
\hline Sentember. ............... & 16.8 & 17.8 & 16.0 & 1.0231 & 1. 0234 & 1. 0228 \\
\hline October & 12.8 & 16.5 & 10.2 & 1.0232 & 1.0238 & 1.0225 \\
\hline Novermber ... & 8.5 & 10.0 & 7.0 & 1.0227 & 1.0234 & 1.0223 \\
\hline December........ & 1.9 & 6.5 & -.3 & 1.0226 & 1.0235 & 1. 0217 \\
\hline Means and extremes & 8.9 & 21.3 & -1.5 & 1. 0223 & 1.0238 & 1.0165 \\
\hline
\end{tabular}

For reference to above table, see p. 28. 
TABLE 44.-Temperature and density of sea water, Boston Harbor, 1926

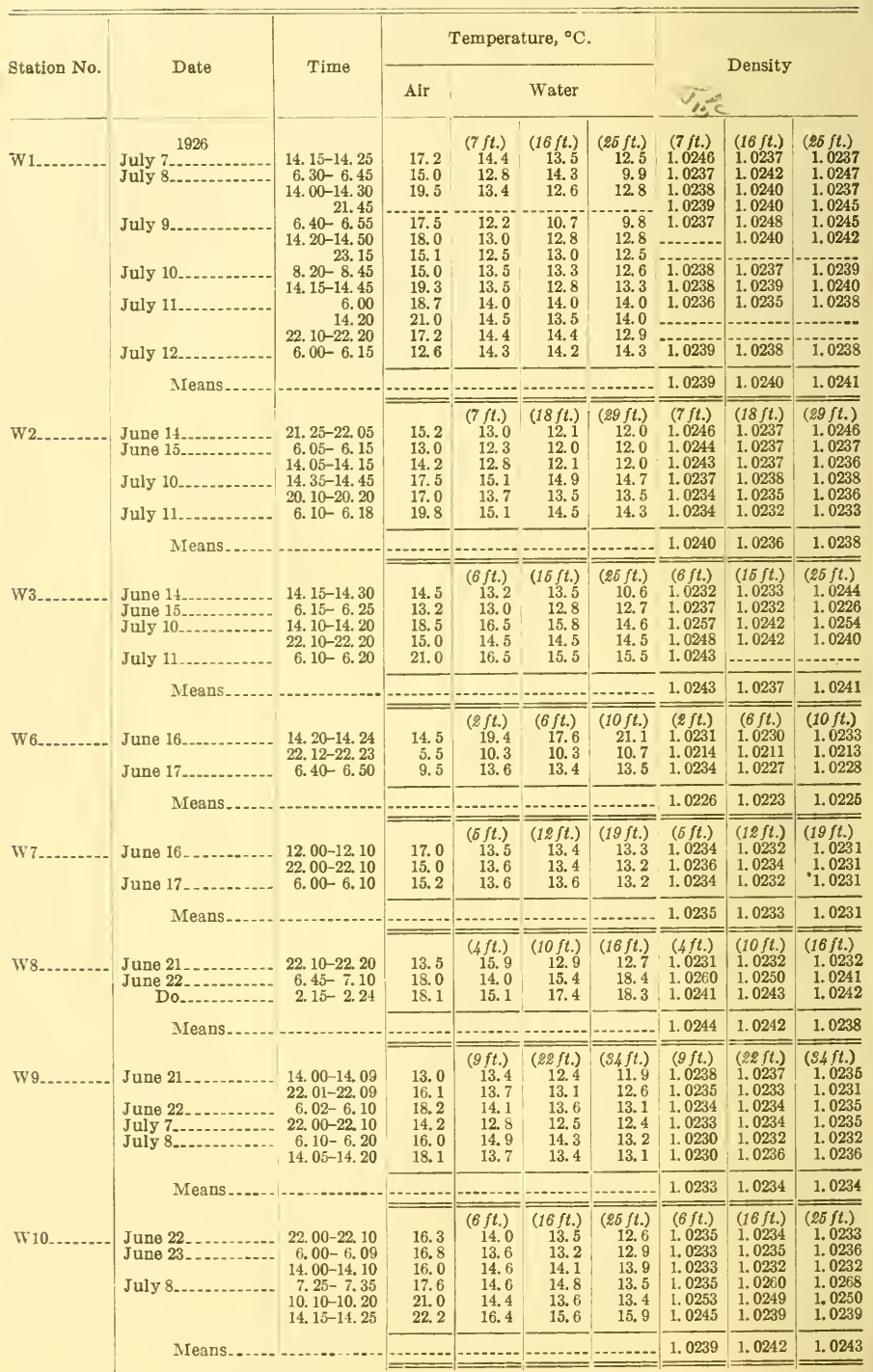


TABLE 44.-Temperature and density of sea water, Boston Harbor, 1926-Contd.

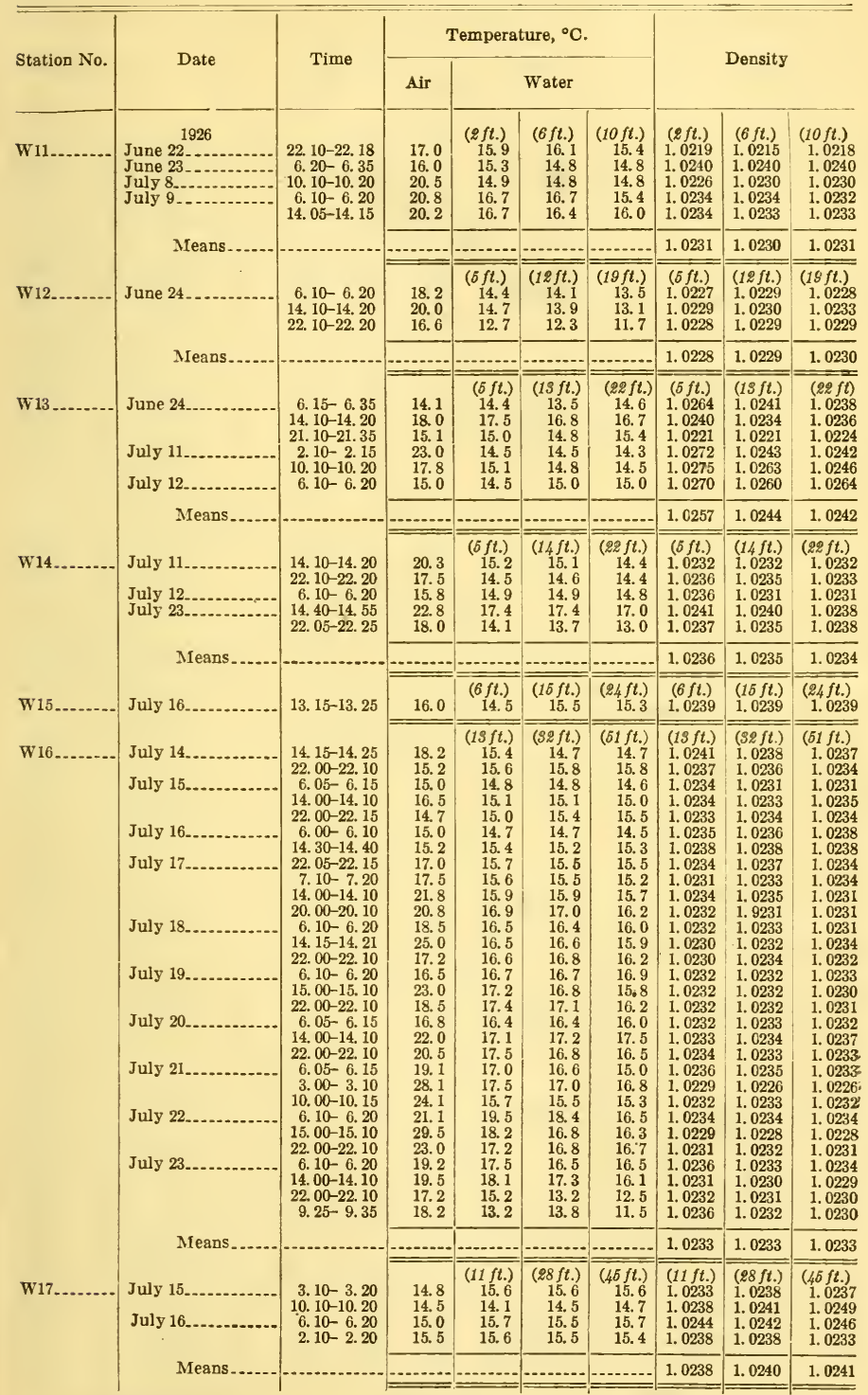

$81772-28-7$ 
TABLE 44.-Temperature and density of sea water, Boston Harbor, 1926-Contd.

\begin{tabular}{|c|c|c|c|c|c|c|c|c|c|}
\hline \multirow{2}{*}{ Station No. } & \multirow{2}{*}{ ate } & \multirow{2}{*}{ Time } & \multicolumn{4}{|c|}{ Temperature, ${ }^{\circ} \mathrm{C}$. } & \multirow{2}{*}{\multicolumn{3}{|c|}{ Density }} \\
\hline & & & Air & & Wat & & & & \\
\hline \multirow[t]{2}{*}{ W18......... } & \multirow{2}{*}{$\begin{array}{c}1926 \\
\text { June } 18 \\
\text { June } 19 . . . \\
\text { Means........ }\end{array}$} & \multirow[t]{2}{*}{$\begin{array}{r}2.00-2.10 \\
10.00-10.10 \\
6.00-6.10\end{array}$} & $\begin{array}{l}19.0 \\
17.0 \\
15.0 \\
\end{array}$ & $\begin{array}{r}(5 f t .) \\
13.0 \\
14.0 \\
13.8 \\
\end{array}$ & $\begin{array}{r}(12 f t .) \\
13.5 \\
13.8 \\
13.6 \\
\end{array}$ & $\begin{array}{r}(20 \mathrm{ft} .) \\
13.5 \\
13.8 \\
13.5 \\
\end{array}$ & $\begin{array}{c}(5 \mathrm{ft} .) \\
1.0235 \\
1.0236 \\
1.0234 \\
\end{array}$ & $\begin{array}{l}(12 f t .) \\
1.0231 \\
1.0236 \\
1.0236 \\
\end{array}$ & $\begin{array}{l}(20 \text { ft. }) \\
1.0232 \\
1.0232 \\
1.0232 \\
\end{array}$ \\
\hline & & & 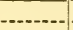 & $\ldots$ & 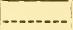 & ........ & 1.0235 & 1.0234 & 1.0232 \\
\hline \multirow[t]{2}{*}{ W19......... } & \multirow{2}{*}{$\begin{array}{r}\text { June } 18 \\
\text { June } 19 \\
\text { Means................ }\end{array}$} & \multirow[t]{2}{*}{$\begin{array}{r}3.20-3.35 \\
22.10-22.23 \\
6.17-6.25\end{array}$} & $\begin{array}{l}17.0 \\
15.3 \\
13.0\end{array}$ & $\begin{array}{r}(2 f t .) \\
17.5 \\
17.1 \\
14.8 \\
\end{array}$ & $\begin{array}{r}(6 f t .) \\
17.7 \\
17.4 \\
14.8 \\
\end{array}$ & $\begin{array}{r}(10 f t .) \\
17.5 \\
17.1 \\
14.7 \\
\end{array}$ & $\begin{array}{l}(2.0 \\
1.0 \\
1.0 \\
1.0\end{array}$ & & $\begin{array}{l}(10 f t .) \\
1.0232 \\
1.0226 \\
1.0228\end{array}$ \\
\hline & & & & & . & $\ldots$ & 3.0229 & 236 & 1. 0229 \\
\hline \multirow[t]{2}{*}{ W20............ } & \multirow{2}{*}{$\begin{array}{l}\text { June } 25 \\
\text { June } 26 \\
\text { July } 8 \\
\text { July } 9 \\
\quad \text { Means...... }\end{array}$} & \multirow[t]{2}{*}{$\begin{array}{r}14.10-14.20 \\
22.00-22.10 \\
6.10-6.12 \\
10.10-10.20 \\
6.10-6.20 \\
2.10-2.20\end{array}$} & $\begin{array}{l}20.8 \\
17.2 \\
20.0 \\
20.1 \\
18.5 \\
18.9\end{array}$ & $\begin{array}{r}(s f t .) \\
14.6 \\
12.6 \\
15.3 \\
15.0 \\
16.4 \\
15.1 \\
\end{array}$ & $\begin{array}{r}(8 f t .) \\
13.8 \\
12.2 \\
15.3 \\
16.4 \\
16.4 \\
16.4 \\
\end{array}$ & $\begin{array}{r}(12 f t .) \\
12.8 \\
11.8 \\
14.4 \\
14.5 \\
16.4 \\
16.4 \\
\end{array}$ & $\begin{array}{l}(s f t .) \\
1.0230 \\
1.0234 \\
1.0228 \\
1.0257 \\
1.0238 \\
1.0240\end{array}$ & $\begin{array}{l}(8 f t .) \\
1.0231 \\
1.0233 \\
1.0229 \\
1.0251 \\
1.0248 \\
1.0240 \\
\end{array}$ & $\begin{array}{l}(12 \mathrm{ft} .) \\
1.0235 \\
1.0232 \\
1.0231 \\
1.0244 \\
1.0252 \\
1.0244 \\
\end{array}$ \\
\hline & & & 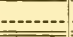 &.- & 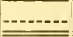 & $\ldots$ & .0238 & 1.0239 & .0240 \\
\hline \multirow[t]{2}{*}{ W21.......... } & \multirow{2}{*}{$\begin{array}{r}\text { June } 25 \\
\text { June } 26 \\
\text { Means................. }\end{array}$} & \multirow[t]{2}{*}{$\begin{array}{r}14.12-14.22 \\
22.20-22.40 \\
6.45-6.55\end{array}$} & $\begin{array}{l}21.5 \\
17.5 \\
16.5 \\
\end{array}$ & $\begin{array}{r}(\$ f t .) \\
21.8 \\
15.2 \\
15.9 \\
\end{array}$ & $\begin{array}{r}(8 f t .) \\
21.8 \\
14.9 \\
15.9 \\
\end{array}$ & $\begin{array}{r}(14 f t .) \\
15.9 \\
14.6 \\
14.9 \\
\end{array}$ & $\begin{array}{l}(s f t .) \\
1.0234 \\
1.0242 \\
1.0239 \\
\end{array}$ & $\begin{array}{l}(8 f t .) \\
1.0231 \\
1.0246 \\
1.0241 \\
\end{array}$ & $\begin{array}{l}(1 . \mathrm{ft} .) \\
1.0231 \\
1.0240 \\
1.0238 \\
\end{array}$ \\
\hline & & & $=$ & $\ldots$ & $\ldots$ & ............ & 1.0238 & 1.0239 & 1.0236 \\
\hline \multirow[t]{2}{*}{ W23......... } & \multirow{2}{*}{$\begin{array}{r}\text { June } 29 \\
\text { June } 30 \\
\text { Means................. }\end{array}$} & \multirow[t]{2}{*}{$\begin{array}{r}14.10-14.35 \\
22.10-22.20 \\
6.15-6.25\end{array}$} & $\begin{array}{l}17.5 \\
18.8 \\
17.2 \\
\end{array}$ & $\begin{array}{c}(7 f t .) \\
13.9 \\
17.2 \\
15.6 \\
\end{array}$ & $\begin{array}{r}(18 f t .) \\
14.8 \\
15.2 \\
14.2 \\
\end{array}$ & $\begin{array}{r}(27 f t .) \\
14.4 \\
14.2 \\
14.0 \\
\end{array}$ & $\begin{array}{c}(7 f t .) \\
1.0239 \\
1.0234 \\
1.0260 \\
\end{array}$ & $\begin{array}{l}(18 f t .) \\
1.0240 \\
1.0230 \\
1.0244\end{array}$ & $\begin{array}{l}(27 f t .) \\
1.0236 \\
1.0230 \\
1.0237 \\
\end{array}$ \\
\hline & & & $=$ & & & -- & 1.0244 & 1.0238 & 0234 \\
\hline \multirow[t]{2}{*}{ W24............. } & \multirow[t]{2}{*}{$\begin{array}{l}\text { June } 30 \\
\text { July } 1\end{array}$} & \multirow[t]{2}{*}{$\begin{array}{r}22.18-22.45 \\
1.50-2.22 \\
6.10-6.20 \\
14.10-14.20\end{array}$} & $\begin{array}{l}19.5 \\
17.5 \\
15.6 \\
18.4\end{array}$ & $\begin{array}{r}(4 f t .) \\
18.2 \\
18.4 \\
16.0 \\
16.7 \\
\end{array}$ & $\begin{array}{r}(10 \mathrm{ft} .) \\
16.2 \\
16.3 \\
14.8 \\
15.0 \\
\end{array}$ & $\begin{array}{r}(16 f t .) \\
15.8 \\
15.7 \\
14.8 \\
15.0\end{array}$ & $\begin{array}{l}(4 f t .) \\
1.0228 \\
1.0236 \\
1.0240 \\
1.0231 \\
\end{array}$ & $\begin{array}{l}f t .) \\
228 \\
231 \\
235 \\
231\end{array}$ & $\begin{array}{l}16 \text { ft. } \\
1.0236 \\
1.0236 \\
1.0235 \\
1.0232\end{array}$ \\
\hline & & & $=$ & $=$ & 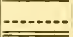 & -......... & 0234 & 31 & 235 \\
\hline \multirow[t]{2}{*}{ W25............. } & \multirow{2}{*}{$\begin{array}{l}\text { June } 30 \\
\text { July } 1 . \\
\text { Means......... }\end{array}$} & \multirow[t]{2}{*}{$\begin{array}{r}14.05-14.12 \\
22.05-22.15 \\
6.05-6.15\end{array}$} & $\begin{array}{l}27.4 \\
16.4 \\
16.3\end{array}$ & $\begin{array}{c}\text { (2ft.) } \\
17.0 \\
16.4 \\
15.8 \\
\end{array}$ & $\begin{array}{r}(6 f t .) \\
16.4 \\
16.1 \\
16.0 \\
\end{array}$ & $\begin{array}{r}(10 \mathrm{ft} .) \\
16.0 \\
15.8 \\
15.7\end{array}$ & $\begin{array}{l}(2 f t .) \\
1.0218 \\
1.0215 \\
1.0219\end{array}$ & $\begin{array}{c}(6 f t .) \\
1.0220 \\
1.0218 \\
1.0222 \\
\end{array}$ & $\begin{array}{l}(10 f t .) \\
1.0224 \\
1.0221 \\
1.0226 \\
\end{array}$ \\
\hline & & & & 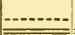 & & .......... & 217 & 20 & 0224 \\
\hline \multirow[t]{2}{*}{ W26........... } & \multirow{2}{*}{$\begin{array}{l}\text { July } 14 \\
\text { July } 15 . \\
\text { Means. }\end{array}$} & \multirow[t]{2}{*}{$\begin{array}{r}2.10-2.20 \\
10.10-10.20 \\
6.10-6.20\end{array}$} & $\begin{array}{l}14.4 \\
15.6 \\
15.5 \\
\end{array}$ & $\begin{aligned}(6 f t .) \\
16.8 \\
16.7 \\
16.2 \\
\end{aligned}$ & $\begin{array}{r}(16 \mathrm{ft} .) \\
16.0 \\
16.6 \\
15.9 \\
\end{array}$ & $\begin{array}{r}(26 f t .) \\
15.5 \\
16.6 \\
15.7 \\
\end{array}$ & $\begin{array}{c}(6 f t .) \\
1.0238 \\
1.0239 \\
1.0251 \\
\end{array}$ & $\begin{array}{l}f t .) \\
237 \\
243 \\
244 \\
\end{array}$ & $\begin{array}{r}(26 f t .) \\
1.0237 \\
1.0240 \\
1.0244 \\
\end{array}$ \\
\hline & & & & & & -.....- & 1.0243 & 1.0241 & 0240 \\
\hline \multirow[t]{2}{*}{ W28............. } & \multirow{2}{*}{$\begin{array}{l}\text { July } 14 \\
\text { July } 15 \\
\text { Means........ }\end{array}$} & \multirow[t]{2}{*}{$\begin{array}{r}14.00-14.30 \\
6.15-6.45\end{array}$} & $\begin{array}{l}18.0 \\
15.3 \\
\end{array}$ & $\begin{array}{r}(s f t .) \\
16.2 \\
16.6 \\
\end{array}$ & $\begin{array}{r}(8 \mathrm{ft} .) \\
15.7 \\
16.5 \\
\end{array}$ & $\begin{array}{r}(12 f t .) \\
15.7 \\
16.5 \\
\end{array}$ & $\begin{array}{l}(3 f t .) \\
1.0240 \\
1.0237 \\
\end{array}$ & $\begin{array}{l}(8 f t .) \\
1.0238 \\
1.0237 \\
\end{array}$ & $\begin{array}{r}(12 f t .) \\
1.0234 \\
1.0237 \\
\end{array}$ \\
\hline & & & & & & & 1.0238 & 1.0238 & $\overline{0236}$ \\
\hline W29......... & $\begin{array}{l}\text { July } 19 \ldots \\
\text { July } 20 \ldots\end{array}$ & $\begin{array}{r}2.10-2.20 \\
10.15-10.25 \\
6.10-6.20\end{array}$ & $\begin{array}{l}20.0 \\
19.3 \\
17.1 \\
\end{array}$ & $\begin{array}{r}(7 f t .) \\
19.5 \\
18.5 \\
17.2 \\
\end{array}$ & $\begin{array}{r}(16 \mathrm{ft} .) \\
18.5 \\
18.5 \\
16.9 \\
\end{array}$ & $\begin{array}{r}(26 f t .) \\
19.0 \\
18.3 \\
16.7 \\
\end{array}$ & $\begin{array}{l}(7 f t .) \\
1.0232 \\
1.0235 \\
1.0234 \\
\end{array}$ & $\begin{array}{l}(16 \mathrm{ft} .) \\
1.0229 \\
1.0255 \\
1.0235 \\
\end{array}$ & $\begin{array}{l}(26 f t .) \\
1.0228 \\
1.0233 \\
1.0233 \\
\end{array}$ \\
\hline & Mean & -.. & $\ldots$ & $\ldots$ & $-\ldots$ & 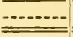 & 1.0234 & 1.0240 & 1.0231 \\
\hline 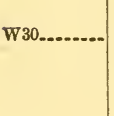 & $\begin{array}{l}\text { July } 19 . \\
\text { July } 20 .\end{array}$ & $\begin{array}{r}14.35-14.45 \\
22.10-22.30 \\
6.40-6.55 \\
14.10-14.25 \\
22.10-22.25\end{array}$ & $\begin{array}{l}22.0 \\
18.5 \\
18.0 \\
30.0 \\
21.8 \\
\end{array}$ & $\begin{array}{r}(7 f t .) \\
18.1 \\
18.5 \\
16.9 \\
18.8 \\
18.3 \\
\end{array}$ & $\begin{array}{r}(17 f t .) \\
17.3 \\
18.2 \\
16.8 \\
18.0 \\
18.2 \\
\end{array}$ & $\begin{array}{r}(28 \mathrm{ft} .) \\
18.2 \\
18.2 \\
16.8 \\
17.5 \\
18.0 \\
\end{array}$ & $\begin{array}{l}(7 f t .) \\
1.0238 \\
1.0235 \\
1.0238 \\
1.0256 \\
1.0230 \\
\end{array}$ & $\begin{array}{l}(17 f t .) \\
1.0238 \\
1.0233 \\
1.0236 \\
1.0259 \\
1.0231 \\
\end{array}$ & $\begin{array}{l}(28 f t .) \\
1.0237 \\
1.0233 \\
1.0236 \\
1.0244 \\
1.0238 \\
\end{array}$ \\
\hline & Mean & & 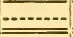 & $=$ & 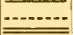 & -..... & 1.0239 & 1.0239 & 1.0237 \\
\hline
\end{tabular}


TABLE 44.-Temperature and density of sea water, Boston Harbor, 1926-Contd.

\begin{tabular}{|c|c|c|c|c|c|c|c|c|c|}
\hline \multirow{4}{*}{$\begin{array}{l}\text { Station No. } \\
\text { W31......... }\end{array}$} & \multirow{2}{*}{\begin{tabular}{|l} 
Date \\
1926
\end{tabular}} & \multirow{4}{*}{$\begin{array}{c}\text { Time } \\
\\
14.15-14.25 \\
22.10-22.25 \\
6.10-6.20\end{array}$} & \multicolumn{4}{|c|}{ Temperature, ${ }^{\circ} \mathrm{C}$} & \multirow{2}{*}{\multicolumn{3}{|c|}{ Density }} \\
\hline & & & \multirow{2}{*}{$\begin{array}{l}\text { Air } \\
\\
\\
29.0 \\
22.3 \\
20.8\end{array}$} & \multicolumn{3}{|c|}{ Water } & & & \\
\hline & $\begin{array}{l}\text { July } 20 \ldots 26 \\
\text { July } 21 . \ldots . . .\end{array}$ & & & $\begin{array}{r}(4 \mathrm{ft} .) \\
19.5 \\
18.5 \\
18.5\end{array}$ & $\begin{array}{r}(8 f t .) \\
20.5 \\
18.5 \\
18.2\end{array}$ & $\begin{array}{r}(1 S f t .) \\
19.5 \\
18.5 \\
18.0\end{array}$ & $\begin{array}{l}(4 f t .) \\
1.0238 \\
1.0233 \\
1.0232\end{array}$ & $\begin{array}{l}(8 f t .) \\
1.0232 \\
1.0233 \\
1.0232\end{array}$ & $\begin{array}{l}(1 s f t .) \\
1.0234 \\
1.0235 \\
1.0229\end{array}$ \\
\hline & Means. & & $\ldots$ & $\ldots$ & $\ldots$ & $\ldots$ & 1.0234 & 1.0232 & 1.0233 \\
\hline \multirow[t]{2}{*}{ W32......... } & $\begin{array}{l}\text { July } 16 \\
\text { July } 17\end{array}$ & \multirow[t]{2}{*}{$\begin{array}{r}10.10-10.20 \\
5.10-5.20\end{array}$} & $\begin{array}{l}16.0 \\
17.2\end{array}$ & $\begin{array}{r}(\gamma f t .) \\
17.0 \\
16.5\end{array}$ & $\begin{array}{r}(17 f t .) \\
16.0 \\
16.5\end{array}$ & $\begin{array}{r}(28 f t .) \\
16.6 \\
16.0\end{array}$ & $\begin{array}{l}(7 f t .) \\
1.0234 \\
1.0234\end{array}$ & & $\begin{array}{l}(28 f t .) \\
1.0237 \\
1.0231\end{array}$ \\
\hline & Means. & & $\ldots$ & $\ldots$ & $\ldots$ & $\ldots$ & 1.0234 & 1.0237 & 1.0234 \\
\hline \multirow[t]{2}{*}{ W33........... } & \multirow{2}{*}{ 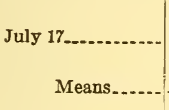 } & \multirow[t]{2}{*}{$\begin{array}{r}7.20-7.50 \\
15.00-15.15\end{array}$} & $\begin{array}{l}19.0 \\
17.3 \\
\end{array}$ & $\begin{array}{r}(7 f t .) \\
16.5 \\
16.5 \\
\end{array}$ & $\begin{array}{r}(17 f t .) \\
16.5 \\
16.1 \\
\end{array}$ & $\begin{array}{r}(27 f t .) \\
16.2 \\
16.0\end{array}$ & $\begin{array}{l}(7 f t .) \\
1.0232 \\
1.0242\end{array}$ & $\begin{array}{l}\overline{(17 f t .)} \\
1.0234 \\
1.0241\end{array}$ & $\begin{array}{r}(27 \text { ft. }) \\
1.0235 \\
1.0237\end{array}$ \\
\hline & & & - & $\ldots$ & -. & - & 1.0237 & 1.0238 & 1.0236 \\
\hline \multirow[t]{2}{*}{ W34........ } & \multirow{2}{*}{$\begin{array}{l}\text { July } 17 . . . . . . . . . . . \\
\qquad \text { Means...... }\end{array}$} & \multirow[t]{2}{*}{$\begin{array}{l}10.10-10.20 \\
14.40-14.55\end{array}$} & $\begin{array}{l}20.0 \\
26.0\end{array}$ & $\begin{array}{l}(7 f t .) \\
20.0 \\
17.1\end{array}$ & $\begin{array}{r}(17 f t .) \\
17.5 \\
16.9\end{array}$ & $\begin{array}{r}(28 \mathrm{ft} .) \\
17.0 \\
16.3\end{array}$ & $\begin{array}{l}(7 f t .) \\
1.0230 \\
1.0233\end{array}$ & $\begin{array}{l}(17 f t .) \\
1.0234 \\
1.0233\end{array}$ & $\begin{array}{l}(28 \mathrm{ft} .) \\
1.0232 \\
1.0252\end{array}$ \\
\hline & & & $\ldots$ & $\ldots$ & - & -- & 1.0232 & 1.0234 & 1. 0242 \\
\hline \multirow[t]{2}{*}{ W35........... } & \multirow{2}{*}{$\begin{array}{r}\text { July } 22 \\
\text { July } 23 \\
\text { Means................. }\end{array}$} & \multirow[t]{2}{*}{$\begin{array}{r}2.10-2.20 \\
10.10-10.20 \\
6.10-6.20\end{array}$} & $\begin{array}{l}37.5 \\
26.8 \\
27.0\end{array}$ & $\begin{array}{r}(4 f t .) \\
23.5 \\
20.3 \\
19.5 \\
\end{array}$ & $\begin{array}{r}(11 f t .) \\
22.5 \\
19.4 \\
19.5 \\
\end{array}$ & $\begin{array}{r}(17 f t .) \\
21.0 \\
19.0 \\
19.0 \\
\end{array}$ & $\begin{array}{l}(4 f t .) \\
\text { 1. } 0229 \\
\text { 1. } 0232 \\
1.0233 \\
\end{array}$ & $\begin{array}{l}(11 \\
1.0 \\
1.0 \\
1.0\end{array}$ & $\begin{array}{l}(17 f t .) \\
1.0231 \\
1.0235 \\
1.0230 \\
\end{array}$ \\
\hline & & & & -... & $\ldots$ & ב........ & 1.0231 & 1. 0231 & 1.0232 \\
\hline \multirow[t]{2}{*}{ W36......... } & \multirow{2}{*}{$\begin{array}{l}\text { July } 26 \\
\text { July } 27 \\
\text { Means........ }\end{array}$} & \multirow[t]{2}{*}{$\begin{array}{r}2.00-2.20 \\
10.10-10.20 \\
6.10-6.20\end{array}$} & $\begin{array}{l}19.0 \\
16.7 \\
17.0\end{array}$ & \begin{tabular}{r|}
$(7 f t)$. \\
18.5 \\
18.2 \\
18.0
\end{tabular} & $\begin{array}{r}(17 f t .) \\
18.5 \\
17.9 \\
18.0\end{array}$ & $\begin{array}{r}(28 \mathrm{ft} .) \\
18.0 \\
17.5 \\
18.5 \\
\end{array}$ & $\begin{array}{l}(7 f t .) \\
1.0254 \\
1.0270 \\
1.0258\end{array}$ & $\begin{array}{l}(17 f t .) \\
1.0260 \\
1.0260 \\
1.0261\end{array}$ & $\begin{array}{l}(28 f t .) \\
1.0259 \\
1.0255 \\
1.0263\end{array}$ \\
\hline & & & & $=$ & -- & $\cdots$ & 1.0261 & 1.0260 & 0259 \\
\hline \multirow[t]{2}{*}{ W37........ } & \multirow[t]{2}{*}{$\begin{array}{l}\text { July } 21 \\
\text { July } 22 \\
\text { July } 26-\ldots \\
\text { July } 27 \\
\text { July } 28 \\
\text { Do Do } \\
\text { July } 29 \\
\text { July } 30 \\
\end{array}$} & $\begin{array}{r}14.15-14.25 \\
22.10-22.25 \\
6.15-6.25 \\
14.15-14.45 \\
5.45-6.15 \\
6.12- \\
14.00-14.10 \\
22.00-22.10 \\
14.00-14.10 \\
22.00-22.10 \\
6.05-6.15 \\
14.00-14.10 \\
22.00-22.10\end{array}$ & $\begin{array}{l}33.5 \\
30.0 \\
26.4 \\
19.0 \\
16.9 \\
18.8 \\
22.9 \\
19.5 \\
16.1 \\
16.0 \\
17.8 \\
18.0 \\
15.5 \\
\end{array}$ & $\begin{aligned} &\left(8 f_{t}^{t}\right) \\
& 22.5 \\
& 20.5 \\
& 19.2 \\
& 18.5 \\
& 18.0 \\
& 18.1 \\
& 17.7 \\
& 17.1 \\
& 17.5 \\
& 17.5 \\
& 17.3 \\
& 17.6 \\
& 17.5\end{aligned}$ & \begin{tabular}{r|}
$(19 f t)$. \\
22.0 \\
19.5 \\
18.3 \\
17.8 \\
17.6 \\
17.6 \\
17.3 \\
16.8 \\
17.0 \\
17.2 \\
17.2 \\
17.0 \\
16.9 \\
\end{tabular} & $\begin{array}{r}(\$ 0 \text { ft. }) \\
21.5 \\
19.5 \\
18.2 \\
17.8 \\
17.5 \\
17.3 \\
17.0 \\
17.2 \\
16.8 \\
16.8 \\
16.9 \\
16.2 \\
16.2 \\
\end{array}$ & $\begin{array}{l}(8 f t .) \\
1.0230 \\
1.0231 \\
1.0232 \\
1.0227 \\
1.0227 \\
1.0238 \\
1.0231 \\
1.02228 \\
1.0228 \\
1.0229 \\
1.0229 \\
1.0215 \\
1.0208\end{array}$ & $\begin{array}{l}(19 f t .) \\
1.0225 \\
1.0234 \\
1.0233 \\
1.0229 \\
1.0232 \\
1.0231 \\
1.0231 \\
1.0229 \\
1.0227 \\
1.0230 \\
1.0229 \\
1.0224 \\
1.0212 \\
\end{array}$ & $\begin{array}{r}(30 f t .) \\
1.0228 \\
1.0235 \\
1.0229 \\
1.0232 \\
1.0237 \\
-1.0230 \\
1.0229 \\
1.0228 \\
1.0229 \\
1.0229 \\
1.0226 \\
1.0213 \\
\end{array}$ \\
\hline & & \multirow{3}{*}{$\begin{array}{r}14.20-14.40 \\
22.10-22.20 \\
6.10-6.20\end{array}$} & & $\Rightarrow$ & & -......... & 1.0227 & 1. 0228 & 0229 \\
\hline \multirow[t]{2}{*}{ W38........... } & \multirow[t]{2}{*}{ July 27} & & $\begin{array}{l}23.0 \\
21.3 \\
17.5 \\
\end{array}$ & $\begin{array}{r}(7 f t .) \\
18.0 \\
18.5 \\
17.5 \\
\end{array}$ & $\begin{array}{r}(17 \mathrm{ft} .) \\
17.5 \\
18.0 \\
17.5 \\
\end{array}$ & $\begin{array}{r}(28 \mathrm{ft} .) \\
17.5 \\
17.3 \\
17.5 \\
\end{array}$ & $\begin{array}{l}(7 \mathrm{ft} .) \\
1.0252 \\
1.0230 \\
1.0227\end{array}$ & $\begin{array}{l}(17 f t .) \\
1.0250 \\
1.0227 \\
1.0224\end{array}$ & $\begin{array}{l}(28 \mathrm{ft} .) \\
1.0253 \\
1.0229 \\
1.0226\end{array}$ \\
\hline & & & & & 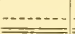 & - & 1.0236 & 1.0234 & 1.0236 \\
\hline \multirow[t]{2}{*}{ W39......... } & \multirow[t]{2}{*}{ July 28} & $\begin{array}{r}2.10-2.25 \\
10.10-10.20\end{array}$ & $\begin{array}{l}23.0 \\
20.9\end{array}$ & 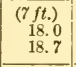 & $\begin{array}{r}(17 f t .) \\
17.5 \\
18.1 \\
\end{array}$ & $\begin{array}{r}(28 f t .) \\
17.3 \\
17.5 \\
\end{array}$ & $\begin{array}{l}(7 f t .) \\
1.0227 \\
1.0224 \\
\end{array}$ & $\begin{array}{l}(17 f t .) \\
1.0228 \\
1.0221 \\
\end{array}$ & $\begin{array}{l}(28 \mathrm{ft} .) \\
1.0226 \\
1.0227\end{array}$ \\
\hline & & & & 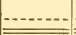 & - & - & 1.0226 & 1. 0224 & 1.0226 \\
\hline W & $\begin{array}{l}\text { July } 28 \ldots \\
\text { July } 29 . .\end{array}$ & $\begin{array}{l}13.45-14.25 \\
14.00-14.15\end{array}$ & $\begin{array}{l}24.0 \\
15.0 \\
\end{array}$ & $\begin{array}{r}(7 f t .) \\
18.0 \\
17.8 \\
\end{array}$ & $\begin{array}{r}(18 f t .) \\
17.7 \\
17.6 \\
\end{array}$ & $\begin{array}{r}(28 \mathrm{ft} .) \\
17.5 \\
17.5 \\
\end{array}$ & $\begin{array}{l}(7 f t .) \\
1.0231 \\
1.0238\end{array}$ & $\begin{array}{l}(18 f t .) \\
1.0237 \\
1.0231\end{array}$ & $\begin{array}{c}(28 f t .) \\
1.0247 \\
1.0229\end{array}$ \\
\hline & Mear & & & 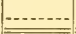 & & , n........ & 1.0234 & 1.0234 & 1.0238 \\
\hline W41.. & July 29. & $\begin{array}{r}6.10-6.20 \\
10.10-10.20 \\
2.10-2.17\end{array}$ & $\begin{array}{l}18.0 \\
15.5 \\
16.0 \\
\end{array}$ & $\begin{array}{c}(6 f t .) \\
18.0 \\
17.8 \\
17.0 \\
\end{array}$ & $\begin{array}{r}(16 \text { ft. }) \\
18.0 \\
17.4 \\
17.0 \\
\end{array}$ & $\begin{array}{r}26 \mathrm{ft} .) \\
17.5 \\
17.2 \\
17.0 \\
\end{array}$ & $\begin{array}{l}(6 \mathrm{ft} .) \\
1.0226 \\
1.0224 \\
1.0225\end{array}$ & $\begin{array}{l}(16 f t .) \\
1.0229 \\
1.0228 \\
1.0231\end{array}$ & $\begin{array}{c}(26 f t .) \\
1.0229 \\
1.0227 \\
1.0231\end{array}$ \\
\hline & Mea & & & & $\cdots$ & -......... & 1.0225 & 1.0229 & 1.0229 \\
\hline
\end{tabular}


TABLE 44.-Temperature and density of sea water, Boston Harbor, 1926-Contd.

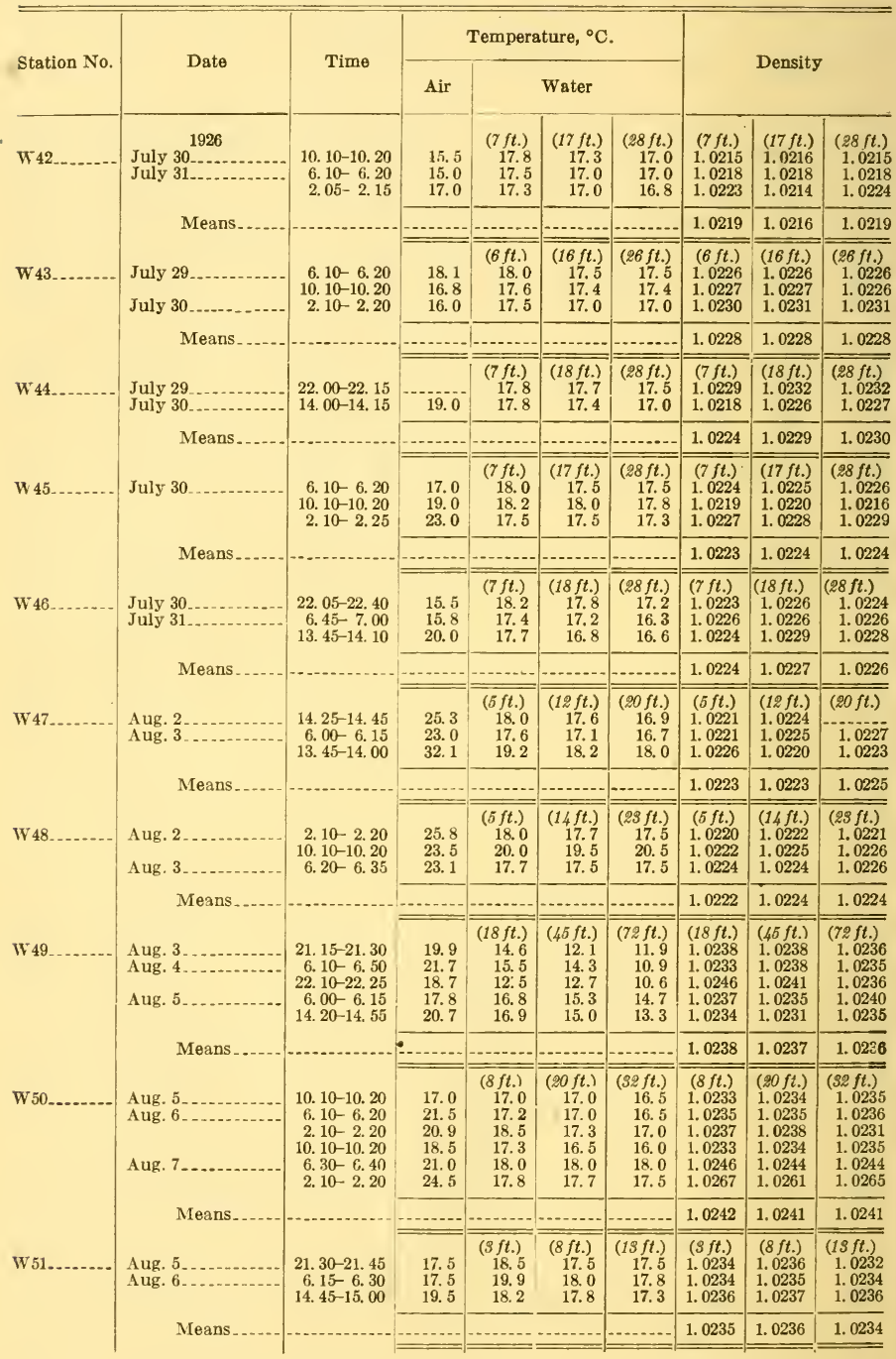


TABLE 44.-Temperature and density of sea water, Boston Harbor, 1926-Contd.

\begin{tabular}{|c|c|c|c|c|c|c|c|c|c|}
\hline \multirow{2}{*}{ Station No. } & \multirow{2}{*}{ Date } & \multirow{2}{*}{ Time } & \multicolumn{4}{|c|}{ Temperature, ${ }^{\circ} \mathrm{C}$. } & \multirow{2}{*}{\multicolumn{3}{|c|}{ Density }} \\
\hline & & & Air & & Water & & & & \\
\hline \multirow[t]{2}{*}{ W52........ } & \multirow[t]{2}{*}{$\begin{array}{l}1926 \\
\text { Aug. } 3 \\
\text { Aug. } 4 \\
\text { Aug. } 5 \\
\text { Means ...... }\end{array}$} & \multirow[t]{2}{*}{$\begin{array}{r}10.10-10.20 \\
6.10-6.20 \\
2.10-2.20 \\
10.10-10.20 \\
6.10-6.20 \\
2.10-2.20\end{array}$} & $\begin{array}{l}20.0 \\
22.7 \\
28.2 \\
20.5 \\
19.0 \\
19.2\end{array}$ & $\begin{array}{r}(12 f t .) \\
18.5 \\
14.5 \\
16.0 \\
17.0 \\
14.7 \\
16.0\end{array}$ & $\begin{array}{r}(30 \text { ft. }) \\
19.0 \\
14.0 \\
14.0 \\
16.5 \\
14.5 \\
13.8\end{array}$ & $\begin{array}{r}(48 f t .) \\
19.0 \\
13.5 \\
11.6 \\
16.5 \\
14.0 \\
12.0\end{array}$ & $\begin{array}{l}(12 \text { ft. }) \\
\text { 1. } 0237 \\
\text { 1. } 0227 \\
\text { 1. } 0232 \\
\text { 1. } 0235 \\
\text { 1. } 0235 \\
1.0231\end{array}$ & $\begin{array}{l}(30 \mathrm{ft} .) \\
1.0240 \\
1.0225 \\
1.0229 \\
1.0236 \\
1.0236 \\
1.0232\end{array}$ & $\begin{array}{l}(48 f t .) \\
1.0241 \\
1.0223 \\
1.0228 \\
1.0236 \\
1.0238 \\
1.0234\end{array}$ \\
\hline & & & & 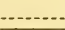 & $\ldots$ & $\ldots$ & 1. 0233 & 1.0233 & 1. 0233 \\
\hline W54 & \multirow{3}{*}{$\begin{array}{l}\text { Aug. } 7 \\
\text { Aug. } 9 \\
\text { Aug. } 10 \\
\quad \text { Means..... }\end{array}$} & \multirow{3}{*}{$\begin{array}{r}6.15-6.50 \\
10.10-10.20 \\
3.10-3.20\end{array}$} & 20.2 & $\begin{array}{r}(s f t .) \\
18.0\end{array}$ & $\begin{array}{c}(8 f t .) \\
17.7 \\
\end{array}$ & $\begin{array}{r}(1 S \mathrm{ft} .) \\
17.5 \\
\end{array}$ & $\begin{array}{l}(3 f t .) \\
1.0235\end{array}$ & $\begin{array}{c}(8 \mathrm{ft} .) \\
1.0236\end{array}$ & $\begin{array}{l}(13 \mathrm{ft} .) \\
1.0235\end{array}$ \\
\hline \multirow[t]{2}{*}{ W55......... } & & & $\begin{array}{l}23.0 \\
21.0\end{array}$ & $\begin{array}{r}(4 f t .) \\
19.6 \\
18.0\end{array}$ & $\begin{array}{r}(11 f t .) \\
19.6 \\
17.5\end{array}$ & $\begin{array}{r}(18 f t .) \\
19.4 \\
17.5\end{array}$ & $\begin{array}{l}(4 f t .) \\
1.0267 \\
1.0265\end{array}$ & $\begin{array}{l}(11 f t .) \\
1.0268 \\
1.0261\end{array}$ & $\begin{array}{c}(18 f t .) \\
1.0264 \\
1.0259\end{array}$ \\
\hline & & & & & & $\ldots$ & 1.0266 & 1.0264 & 1.0262 \\
\hline
\end{tabular}

For reference to above table, see p. 28. 


\title{
A P P E N D I X
}

\section{GENERAL CHARACTERISTICS OF TIDES AND CURRENTS}

\author{
[Reprinted from United States Coast and Geodetic Survey Special Publication No. 111]
}

\section{TIDES, GENERAL CHARACTERISTICS}

\section{DEFINITIONS}

The tide is the name given to the alternate rising and falling of the level of the sea which at most places occurs twice daily. The striking feature of the tide is its intimate relation to the movement of the moon. High water and low water at any given place follow the moon's meridian passage by a very nearly constant interval, and since the moon in its apparent movement around the earth crosses a given meridian, on the average, 50 minutes later each day, the tide at most places likewise comes later each day by 50 minutes, on the average. The tidal day, like the lunar day, therefore, has an average length of 24 hours and 50 minutes.

With respect to the tide, the "moon's meridian passage" has a special signifcance. It refers not only to the instant when the moon is directly above the meridian, but also to the instant when the moon is directly below the meridian, or $180^{\circ}$ distant in longitude. In this sense there are two meridian passages in a tidal day, and they are distinguished by being referred to as the upper and lower meridian passages or upper and lower transits.

The interval between the moon's meridian passage (upper or lower) and the following high water is known as the "high-water lunitidal interval." Likewise the interval between the moon's meridian passage and the following low water is known as the "low-water lunitidal interval." For short they are called, respectively, high-water interval and low-water interval and abbreviated as follows: HWI and LWI.

In its rising and falling the tide is accompanied by a horizontal forward and backward movement of the water, called the tidal current. The two movements - the vertical rise and fall of the tide and the horizontal forward and backward movement of the tidal current-are intimately related, forming parts of the same phenomenon brought about by the tidal forces of sun and moon.

It is necessary, however, to distinguish clearly between tide and tidal current, for the relation between them is not a simple one nor is it everywhere the same. At one place a strong current may accompany a tide having a very moderate rise and fall while at another place a like rise and fall may be accompanied by a very weak current. Furthermore, the time relations between current and tide vary widely from place to place. For the sake of clearness, therefore, tide should be used to designate the vertical movement of the water and tidal current the horizontal movement.

It is convenient to have a single term to designate the whole phenomenon which includes tides and tidal currents. Unfortunately no such distinct term exists. For years, however, "the tide" or "the tides," or even "flood and ebb," have been used in this general sense, and usually no confusion arises from this usage, since the context indicates the sense intended; but the use of the term "tide" to denote the horizontal movement of the water is confusing and is to be discouraged.

With respect to the rise and fall of the water due to the tide, high water and low water have precise meanings. They refer not so much to the height of the water as to the phase of the tide. High water is the maximum height reached by each rising tide and low water the minimum height reached by each falling tide.

It is important to note that it is not the absolute height of the water which is in question, for it is not at all infrequent at many places to have the low water of one day higher than the high water of another day. Whatever the height of the water, when the rise of the tide ceases and the fall is to begin, the tide is at high water; and when the fall of the tide ceases and the rise is to begin, the tide is at low water. The abbreviations $\mathrm{HW}$ and $\mathrm{LW}$ are frequently used to designate high and low water, respectively. 
In its rising and falling the tide does not move at a uniform rate. From low water the tide begins rising, very slowly at first, but at a constantly increasing rate for about three hours, when the rate of rise is a maximum. The rise then continues at a constantly decreasing rate for the following three hours, when high water is reached and the rise ceases. The falling tide behaves in a similar manner, the rate of fall being least immediately after high water, but increasing constantly for about three hours, when it is at a maximum, and then decreasing for a period of three hours till low water is reached.

The rate of rise and fall and other characteristics of the tide may best be studied by representing the rise and fall graphically. This may be done by reading the height of the tide at regular intervals on a fixed vertical staff graduated to feet and tenths and plotting these heights to a suitable scale on crosssection paper and drawing a smooth curve through these points. A more convenient method is to make use of an automatic tide gauge by means of which the rise and fall of the tide is recorded on a sheet of paper as a continuous curve drawn to a suitable scale. Figure A shows a tide curve for Fort Hamilton, N. Y., for July 4, 1922.

In Figure $\mathrm{A}$ the figures from 0 to 24 , increasing from left to right, represent the hours of the day beginning with midnight. Numbering the hours con-

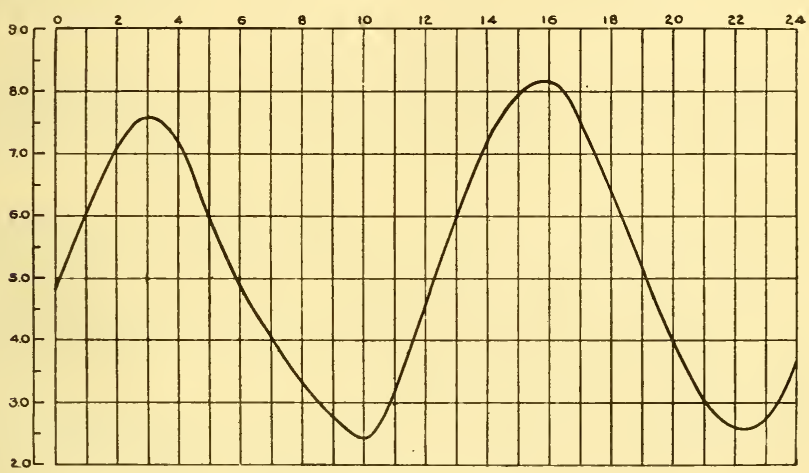

FIG. A.-Tide curve for Fort Hamilton, N. Y., July 4, 1922

secutively to 24 eliminates all uncertainty as to whether morning or afternoon is meant and has the further advantage of great convenience in computation. The figures on the left, increasing upward from 2.0 to 9.0 represent the height of the tide in feet as referred to a fixed vertical staff. The tide curve presents the well-known form of the sine or cosine curve.

The difference in height between a high water and a preceding or following low water is known as the "range of tide" or "range." The average difference in the heights of high and low water at any given place is called the mean range.

\section{THE TIDE-PRODUCING FORCES}

The intensity with which the sun (or moon) attracts a particle of matter on the earth varies inversely as the square of the distance. For the solid earth as a whole the distance is obviously to be measured from the center of the earth, since that is the center of mass of the whole body. But the waters of the earth, which may be considered as lying on the surface of the earth, are on the one side of the earth nearer to the heavenly bodies and on the other side farther away than the center of the earth. The attraction of sun or moon for the waters of the ocean is thus different in intensity from the attraction for the solid earth as a whole, and these differences of attraction give rise to the forces that cause the ocean waters to move relative to the solid earth and bring about the tides. These forces are called the tide-producing forces. 
The mathematical development of these forces shows that the tide-producing force of a heavenly body varies directly as its mass and inversely as the cube of its distance from the earth. The sun has a mass about $26,000,000$ times as great as that of the moon; but it is 389 times as far away from the earth. Its tide-producing force is therefore to that of the moon as $26,000,000$ is to $(389)^{3}$, or somewhat less than one-half.

When the relative motions of the earth, moon, and sun are introduced into the equations of the tide-producing forces, it is found that the tide-producing forces of both sun and moon group themselves into three classes: $(a)$ Those having a period of approximately half a day, known as the semidiurnal forces; $(b)$ those having a period of approximately one day, known as diurnal forces; (c) those having a period of half a month or more, known as long-period forces.

The distribution of the tidal forces over the earth takes place in a regular manner, varying with the latitude. But the response of the various seas to these forces is very profoundly modified by terrestrial features. As a result we find the tides, as they actually occur, differing markedly at various places, but apparently with no regard to latitude.

The principal tide-producing forces are the semidiurnal forces. These forces go through two complete cycles in a tidal day, and it is because of the predominance of these semidaily forces that there are at most places two complete tidal cycles, and therefore two high and two low waters in a tidal day.

\section{VARIATIONS IN RANGE}

The range of the tide at any given place is not constant but varies from day to day; indeed, it is exceptional to find consecutive ranges equal. Obviously changing meteorological conditions will find reflection in variations of range, but the principal variations are due to astronomic causes, being brought about by variations in the position of the moon relative to earth and sun.

At times of new moon and full moon the tidal forces of moon and sun are acting in the same direction. High water then rises higher and low water falls lower than usual, so that the range of the tide at such times is greater than the average. The tides at such times are called "spring tides," and the range of the tide is then known as the "spring range."

When the moon is in its first and third quarters, the tidal forces of sun and moon are opposed and the tide does not rise as high nor fall as low as the average. At such times the tides are called "neap tides," and the range of the tide then is known as the "neap range."

It is to be noted, however, that at most places there is a lag of a day or two between the occurrence of spring or neap tides and the corresponding phases of the moon; that is, spring tides do not occur on the days of full and new moon, but a day or two later. Likewise neap tides follow the moon's first and third quarters after an interval of a day or two. This lag in the response of the tide is known as the "age of phase inequality" or "phase age" and is generally ascribed to the effects of friction.

The varying distance of the moon from the earth likewise affects the range of the tide. In its movement around the earth the moon describes an ellipse in a period of approximately $271 / 2$ days. When the moon is in perigee, or nearest the earth, its tide-producing power is increased, resulting in an increased rise and fall of the tide. These tides are known as "perigean tides," and the range at such times is called the "perigean range." When the moon is farthest from the earth, its tide-producing power is diminished, the tides at such times exhibiting a decreased rise and fall. These tides are called "apogean tides" and the corresponding range the "apogean range."

In the response to the moon's change in position from perigee to apogee. it is found that, like the responses in the case of spring and neap tides, there is a lag in the occurrence of perigean and apogean tides. The greatest rise and fall does not come on the day when the moon is in perigee, but a day or two later. Likewise, the least rise and fall does not occur on the day of the moon's apogee, but a day or two later. This interval varies somewhat from place to place, and in some regions it may have a negative value. This lag is known as the "age of parallax inequality" or "parallax age."

The moon does not move in the plane of the Equator but in an orbit making an angle with that plane of approximately $231 / 2^{\circ}$. During the month, therefore, the moon's declination is constantly changing, and this change in the position of the moon produces a variation in the consecutive ranges of the tide. When the moon is on or close to the Equator-that is, when its declination is small-consecutive ranges do not differ much, morning and afternoon tides be- 
ing very much alike. As the declination increases the difference in consecutive ranges increases, morning and afternoon tides beginning to show decided differences, and at the times of the moon's maximum semimonthly declination these differences are very nearly at a maximum. But like the response to changes in the moon's phase and parallax, there is a lag in the response to the change in declination, this lag being known as the "age of diurnal inequality" or "diurnal age." Like the phase and parallax ages, the diurnal age varies from place to place, being generally about one day, but in some places it may have a negative value.

When the moon is on or close to the Equator and the difference between morning and afternoon tides small, the tides are known as "equatorial tides". At the times of the moon's maximum semimonthly declination, when the differences between morning and afternoon tides are at a maximum, the tides are called "tropic tides," since the moon is then near one of the Tropics.

The three variations in the range of the tide noted above are exhibited by the tide the world over, but not everywhere to the same degree. In many regions the variation from neaps to springs is the principal variation; in certain regions it is the variation from apogee to perigee that is the principal variation; and in other regions it is the variation from equatorial to tropic tides that is the predominant variation.

The month of the moon's phases (the synodical month) is approximately $291 / 2$ days in length; the month of the moon's distance (the anomalistic month) is approximately $271 / 2$ days in length; the month of the moon's declination (the tropic month) is approximately $271 / 3$ days in length. It follows, therefore, that very consideralbe variation in the range of the tide occurs during a year due to the changing relations of the three variations to each other.

\section{DIURNAL INEQUALITY}

The difference between morning and afternoon tides due to the declination of the moon is known as diurnal inequality, and where the diurnal inequality is considerable the rise and fall of the tide is affected to a very marked degree both in time and in height. Figure B represents graphically the differences in the tide at San Francisco on October 18 and 24, 1922. On the former date the moon was over the Equator, while on the latter date the moon was at its maximum south declination for the month. The upper diagram thus represents the equatorial tide for San Francisco, while the lower diagram represents the tropic tide.

It will be noted that on October 18 the morning and afternoon tides show very close resemblance. In both cases the rise from low water to high water and the fall from high water to low water took place in approximately six hours. The heights to which the two high waters attained were very nearly the same, and likewise the depressions of the two low waters.

On October 24, when the moon attained its extreme declination for the fortnight, tropic tides occurred. The characteristics of the rise and fall of the tide on that day differ markedly from those on the 18th, when the equatorial tides occurred, these differences pertaining both to the time and the height. Instead of approximately equal duration of rise and of fall of six hours, both morning and afternoon, as was the case on the 18 th, we now have the morning rise occupying less time than the afternoon rise and the morning fall more time than the evening fall. Even more striking are the differences in extent of rise and fall of morning and afternoon tides. The tide curve shows that there was a difference of a foot in the two high waters of the $24 \mathrm{th}$ and a difference of almost 3 feet in the low waters.

Definite names have been given to each of the two high and two low waters of a tidal day. Of the high waters, the higher is called the "higher high water" and the lower the "lower high water." Likewise, of the two low waters of any tidal day the lower is called "lower low water" and the higher "higher low water."

The diurnal inequality may be related directly to the ratio of the tides brought about, respectively, by the diurnal and semidiurnal tide-producing forces. Those bodies of water which offer relatively little response to the diurnal forces will exhibit but little diurnal inequality, while those bodies which offer relatively considerable response to these diurnal forces will exhibit considerable diurnal inequality. On the Atlantic coast of the United States there is relatively little diurnal inequality, while on the Pacific coast there is considerable inequality.

It is obvious that with increasing diurnal inequality the lower high water and higher low water tend to become equal and merge. When this occurs there is but one high and one low water in a tidal day instead of two. This occurs frequently at Galveston, Tex., and at a number of other places. 


\section{TYPES OF TIDE}

From place to place the characteristics of the rise and fall of the tide generally differ in one or more respects; but according to the predominating features the various kinds of tide may be grouped under three types, namely, semidiurnal, diurnal, and mixed. Instead of semidiurnal and diurnal the terms "semidaily" and "daily" are frequently used.

The semidiurnal type of tide is one in which two high and two low waters occur each tidal day with but little diurnal inequality; that is, morning and afternoon tides resemble each other closely. Figure A may be taken as representing this type of tide, and this is the type found on the Atlantic coast of the United States.

In the diurnal type of tide but one high and one low water occur in a tidal day. Do-Son, French Indo-China, may be cited as a place where the tide is always of

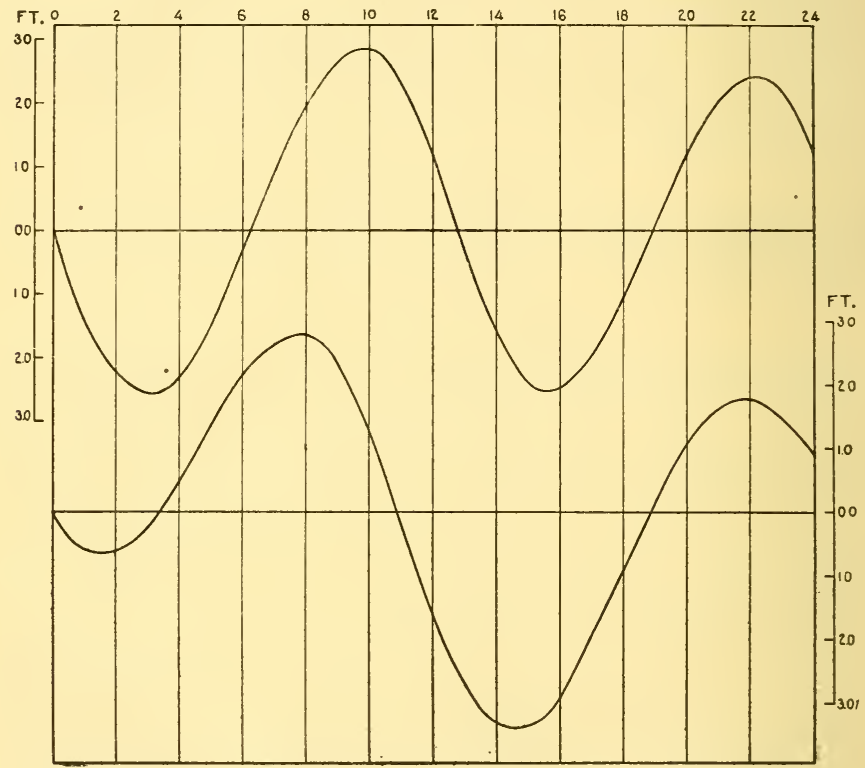

Fic. B. -Tide curves, San Francisco, Calif., October 18 and 24, 1922

the daily type, but it is to be noted that there are not many such places. When the moon's declination is zero the diurnal tidal forces tend to vanish, and there are generally two high and two low waters during the day at such times. Galveston, Tex., and Manila, P. I., may be mentioned as ports at which the tide is frequently diurnal, while St. Michael, Alaska, may be cited as a port at which the tide is largely diurnal.

The mixed type of tide is one in which two high and two low waters occur during the tidal day but which exhibits marked diurnal inequality. Several forms may occur under this type. In one form the diurnal inequality is exhibited principally by the high waters; in another form it is the low waters which exhibit the greater inequality; or the diurnal inequality may be features of both high waters and low waters.

It is to be noted that when the tide at any given place is assigned to any particular type, it refers to the characteristics of the predominating tide at that place. At the time of the moon's maximum semimonthly declination the semidiurnal type exhibits more or less diurnal inequality and thus approaches the mixed type; and when the moon is on or near the Equator the diurnal inequality 
of the mixed type is at a minimum, the tide at such times resembling the semidiurnal type. It is the characteristics of the predominating tide that determine the type of tide at any given place. With the aid of harmonic constants the type of tide may be defined by definite ratios of the semidiurnal to the diurnal constituents.

Type of tide is intimately associated with diurnal inequality and hence depends on the relation of the semidiurnal to the diurnal tides; and it is the variation in this relation that makes possible the various forms of the mixed type of tide.

\section{HARMONIC CONSTANTS}

Since the tide is periodic in character, it may be regarded as the resultant of a number of simple harmonic movements. In other words, if $h$ be the height of the tide, reckoned from sea level, then for any time $t$, we may write $h=A$ cos $(a t+a)+B \cos (b t+\beta)+\ldots$ In the above formula each term represents a constituent of the tide which is defined by its amplitude or semirange, $A, B$, etc., by an angular speed, $a, b$, etc., and by an angle of constant value, $a, \beta$, etc., which determines the relation of time of maximum height to the time of beginning of observation.

We may also regard the matter from another viewpoint and suppose the moon and sun as tide-producing bodies to be replaced by a number of hypothetical tide-producing bodies, each of which moves around the earth in the plane of the Equator in a circular orbit with the earth as center. With the further assumption that each of these hypothetical tide-producing bodies gives rise to a simple tide, the high water of which occurs a certain number of hours after its upper meridian passage and the low water the same number of hours after its lower meridian passage, the oscillation produced by each of these simple tides may be written in the form $h=A \cos (a t+a)$ as above. The great advantage of so regarding the tide is that it permits the complicated movements of sun and moon relative to the earth to be replaced by a number of simple movements.

Each of the simple tides into which the tide of nature is resolved is called a component tide, or simply a component. The amplitudes or semiranges of the component tides, together with the angles which determine the relation of the high water of each of these component tides to some definite time origin and which are known as the epochs, constitute the harmonic constants.

The periods of revolution of the hypothetical tidal bodies or the speeds of the various component tides are computed from astronomical data and depend only on the relative movements of sun, moon, and earth. These periods being independent of local conditions are therefore the same for all places on the surface of the earth; what remains to be determined for the various simple constituent tides is their epochs and amplitudes which vary from place to place according to the type, time, and range of the tide. The mathematical process by which these epochs and amplitudes are disentangled from tidal observations is known as the harmonic analysis.

The number of simple constituent tides is theoretically large, but most of them are of such small magnitude that they may for all practical purposes be disregarded. In the prediction of tides it is necessary to take account of 20 to 30 , but the characteristics of the tide at any place may be determined easily from the 5 principal ones.

It is obvious that the principal lunar tidal component will be one which gives two high and two low waters in a tidal day of 24 hours and 50 minutes, or more exactly in 24.84 hours. Its speed per solar hour, therefore, is $\frac{2 \times 360^{\circ}}{24.84}=28^{\circ} .98$, This component has been given the symbol $\mathrm{M}_{2}$. Likewise, the principal solar tidal component is one that gives two high and two low waters in a solar day of 24 hours. Its angular speed per hour is therefore $\frac{2 \times 360^{\circ}}{24}=30^{\circ} .00$. The symbol for this principal solar component is $\mathrm{S}_{2}$.

Since the moon's distance from the earth is not constant, being less than the average at perigee and greater at apogee, the period from one perigee to another being on the average 27.55 days, we must introduce another hypothetical tidal body, so that at perigee its high water will correspond with the $\mathrm{M}_{2}$ high water, and at apogee its low water will correspond with the $\mathbf{M}_{2}$ high water. In other words, the tidal component which is to take account of the moon's perigean movement must, in a period of 13.78 days, lose $180^{\circ}$ on $\mathrm{M}_{2}$, or at the rate of $180^{\circ}=13^{\circ} .06$ per day. Its hourly speed, therefore, is $28^{\circ} .98-\frac{13^{\circ} .06}{24}=28^{\circ} .44$. This component has been given the symbol $\mathrm{N}_{2}$. 
The moon's change in declination is taken account of by two components denoted by the symbols $K_{1}$ and $\mathrm{O}_{1}$. The speeds of these are determined by the following considerations: The average period from one maximum declination to another is a half tropic month, or 13.66 days. The speeds of these two components should, therefore, be such that when the moon is at its maximum declination they shall both be at a maximum, and when the moon is on the Equator they shall neutralize each other; that is, in a period of 13.66 days $K_{1}$ shall gain on $\mathrm{O}_{1}$ one full revolution. The difference in their hourly speeds, therefore, is $\frac{360^{\circ}}{24 \times 13.66}$ $=1^{\circ} .098$. The mean of the speeds of these two components must be that of the apparent diurnal movement of the moon about the earth, or $\frac{360^{\circ}}{24.84}=14^{\circ} .49$. The speeds are therefore derived from the equations $\frac{\mathrm{K}_{1}+\mathrm{O}_{1}}{2}=14^{\circ} .49$ and $\mathrm{K}_{1}-\mathrm{O}_{1}$ $=1^{\circ} .098$, from which $\mathrm{K}_{1}=15^{\circ} .04$ and $\mathrm{O}_{1}=13^{\circ} .94$.

It is customary to designate the amplitude of any component by the symbol of the component and the epoch by the symbol with a degree mark added. Thus $\mathrm{M}_{2}$ stands for the amplitude of the $\mathrm{M}_{2}$ tide and $\mathrm{M}_{2}{ }^{\circ}$ for the epoch of this tide. The five components enumerated above are the principal ones. Between 20 and 30 components permit the prediction of the time and height of the tide at any given place with considerable precision.

From the harmonic constants the characteristics of the tide at any place can be very readily determined. ${ }^{1}$ The five principal constants alone permit the approximate determination of the tidal characteristics very easily. Thus, approximately, the mean range is $2 \mathrm{M}_{2}$, spring range $2\left(\mathrm{M}_{2}+\mathrm{S}_{2}\right)$, neap range $2\left(\mathrm{M}_{2}-\mathrm{S}_{2}\right)$, perigean range $2\left(\mathrm{M}_{2}+\mathrm{N}_{2}\right)$, apogean range $2\left(\mathrm{M}_{2}-\mathrm{N}_{2}\right)$, diurnal inequality at time of tropic tides $2\left(\mathrm{~K}_{1}+\mathrm{O}_{1}\right)$, high-water lunitidal interval $\mathrm{M}_{2}^{\circ} .98$. The various ages of the tide can likewise be readily determined. Approximately, the ages in hours are: Phase age, $\mathrm{S}_{2}^{\circ}-\mathrm{M}_{2}^{\circ}$; parallax age, $2\left(\mathrm{M}_{2}{ }^{\circ}-\mathrm{N}_{2}^{\circ}\right)$; diurnal age, $\mathrm{K}_{1}^{\circ}-\mathrm{O}_{1}^{\circ}$. The type of tide, too, may be determined from the harmonic constants through the ratio $\frac{\mathrm{K}_{1}+\mathrm{O}_{1}}{\mathrm{M}_{2}+\mathrm{S}_{2}}$. Where this ratio is less than 0.25 , the tide is of the semidiurnal type; where the ratio is between 0.25 and 1.25 , the tide is of the mixed type; and where the ratio is over 1.25 , the tide is of the diurnal type.

The periods of the various component tides, like the periods of the tide-producing forces, group themselves into three classes. The tides in the first class have periods of approximately half a day and are known as semidiurnal tides; the periods of the tides in the second class are approximately one day, and these tides are known as diurnal tides; the tides in the third class have periods of half a month or more and are known as long-period tides. In shallow waters, due to the effects of decreased depth, the tides are modified and another class of simple tides is introduced having periods of less than half a day, and these are known as shallow-water tides.

The class to which any component tide belongs is generally indicated by the subscript used in the notation for the component tides, the subscript giving the number of periods in a day. With long-period tides generally no subseript is used; with semidiurnal tides the subscript is 2 ; with diurnal tides the subseript is 1 , and with shallow-water tides the subscript is 3,4 , or more. Thus Sa represents a solar annual component, $\mathrm{P}_{1}$ a solar diurnal component, $\mathrm{M}_{2}$ a lunar semidiurnal component, $\mathrm{S}_{4}$ a solar shallow-water component with a period of onequarter of a day, and $\mathbf{M}_{6}$ a lunar shallow-water component with a period of one-sixth of a day.

\section{TIDAL DATUM PLANES}

Tidal planes of reference form the basis of all rational datum planes used in practical or scientific work. The advantage of the datum plane based on tidal determination lies not only in simplicity of definition, but also in the fact that it may be recovered at any time, even though all bench-mark connections be lost.

The principal tidal plane is that of mean sea level, which may be defined as the plane about which the tide oscillates, or as the surface the sea would assume when undisturbed by the rise and fall of the tide. At any given place this plane may be determined by deriving the mean height of the tide. This is

1 See R. A. Harris, Manual of Tides, Pt. III (U. S. Coast and Geodetic Survey Report for 1S94, Appendix 7): 
perhaps best done by adding the hourly heights of the tide over a period of a year or more and deriving the mean hourly height. It is to be noted that in such a determination the mean sea level is not freed from the effects of prevailing wind, atmospheric pressure, and other meteorological conditions.

The plane of mean sea level must be carefully distinguished from the plane of half-tide level or, as it is frequently called, mean-tide level. This latter plane is one determined as the half sum of the high and low waters. It is therefore the plane that lies halfway between the planes of mean low water and mean high water. The plane of half-tide level does not, at most places on the open coast, differ by more than about a tenth of a foot from the plane of mean sea level, and where this difference is known the plane of mean sea level may be determined from that of half-tide level. Like all of the tidal planes, the plane of half-tide level should be determined by observations covering a period of a year or more.

For many purposes the plane of mean low water is important. This plane at any given place is determined as the average of all the low waters during a period of a year or more. Where the diurnal inequality in the low waters is small, as on the Atlantic coast of the United States, this plane is frequently spoken of as the "low-water plane" or "the plane of low water"; but strictly it should be called the plane of mean low water.

Where the tides exhibit considerable diurnal inequality in the low waters, as on the Pacific coast of the United States, the lower low waters may fall considerably below the plane of mean low water. In such places the plane of mean ower low water is preferable for most purposes. This plane is determined as the average of all the lower low waters over a period of a year or more. Where the tide is frequently diurnal, the single low water of the day is taken as the lower low water.

The plane of mean high water is determined as the average of all the high waters over a period of a year or more. Where the diurnal inequality in the high waters is small, this plane is frequently spoken of as "the plane of high water" or "the high-water plane." This usage may on occasion lead to confusion, and the denomination of this plane as the plane of mean high water is therefore preferable.

In localities of considerable diurnal inequality in the high waters the higher high waters frequently rise considerably above the plane of mean high water. A higher plane is therefore of importance for many purposes, and the plane of higher high water is preferred. This plane is determined as the average of all the higher high waters for a period of a year or more. Where the tide is frequently diurnal, the single high water of the day is taken as the higher high water.

The tidal planes described above are the principal ones and the ones most generally used. Other planes, however, are sometimes used. Where a very low plane is desired, the plane of mean spring low water is sometimes used, its name indicating that it is determined as the mean of the low waters occurring at spring tides. Another plane sometimes used, which is of interest because based on harmonic constants, is known as the harmonic tide plane and for any given place is determined as $\mathrm{M}_{2}+\mathrm{S}_{2}+\mathrm{K}_{1}+\mathrm{O}_{1}$ below mean sea level.

\section{MEAN VALUES}

Since the rise and fall of the tide varies from day to day, chiefly in accordance with the changing positions of sun and moon relative to the earth, any tidal quantities determined directly from a short series of tidal observations must be corrected to a mean value. The principal variations are those connected with the moon's phase, parallax, and declination, the periods of which are approximately $291 / 2$ days, $271 / 2$ days, and $271 / 3$ days, respectively.

In a period of 29 days, therefore, the phase variation will have almost completed a full cycle while the other variations will have gone through a full cycle and but very little more. Hence, for tidal quantities varying largely with the phase variation, tidal observations covering 29 days, or multiples, constitute a satisfactory period for determining these quantities. Such are the lunitidal intervals, the mean range, mean high water, and mean low water. For quantities varying largely with the declination of the moon, as, for example, higher high water and lower low water, 27 days, or multiples, constitute the more satisfactory period.

As will be seen in the detailed discussion of the tides at Fort Hamilton, the values determined from two different 29-day or 27-day periods may differ very considerably. This is d $\mathrm{e}$ e to the fact that these periods are not exact synodic perior's for the different variations, and to the further fact that variations having periods greater than a month are not taken into account. Furthermore, meteoro- 
logical conditions, which change from month to month, leave their impress on the tides. For accurate results the direct determination of the tidal datum planes and other tidal quantities should be based on a series of observations that cover a period of a year or preferably three years. Values derived from shorter series must be corrected to a mean value.

Two methods may be employed for correcting the results of short series to a mean value. One method makes use of tabular values, determined both from theory and observation, for correcting for the different variations. The other method makes use of direct comparison with simultaneous observations at some near-by port for which mean values have been determined from a series of considerable length.

\section{TIDAL CURRENTS, GENERAL CHARACTERISTICS}

\section{DEFINITIONS}

Tidal currents are the horizontal movements of the water that accompany the rising and falling of the tide. The horizontal movement of the tidal current and the vertical movement of the tide are intimately related parts of the same phenomenon brought about by the tide-producing forces of sun and moon. Tidal currents, like the tides, are therefore periodic.

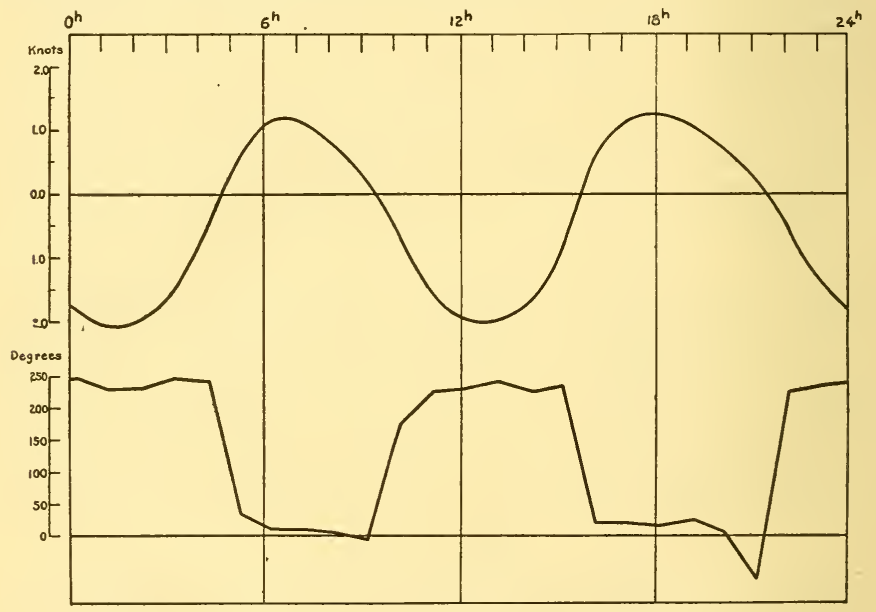

FIG. C.-Velocity and direction curves for the current, Hudson River, July 22, 1922

It is the periodicity of the tidal current that chiefly distinguishes it from other kinds of currents, which are known by the general name of nontidal currents. These latter currents are brought about by causes that are independent of the tides, such as winds, fresh-water run-off, and differences in density and temperature. Currents of this class do not exhibit the periodicity of tidal currents.

Tidal and nontidal currents occur together in the open sea and in inshore tidal waters, the actual currents experienced at any point being the resultant of the two classes of currents. In some places tidal currents predominate and in others nontidal currents predominate. Tidal currents generally attain considerable velocity in narrow entrances to bays, in constricted parts of rivers, and in passages from one body of water to another. Along the coast and farther offshore tidal currents are generally of moderate velocity; and in the open sea, calculation based on the theory of wave motion, gives a tidal current of less than one-tenth of a knot. 


\section{RECTILINEAR TIDAL CURRENTS}

In the entrance to a bay or river and, in general, where a restricted width occurs, the tidal current is of the rectilinear or reversing type; that is, the flood current runs in one direction for a period of about six hours and the ebb current for a like period in the opposite direction. The flood current is the one that sets inland or upstream and the ebb current the one that sets seaward or downstream. The change from flood to ebb gives rise to a period of slack water during which the velocity of the current is zero. An example of this type of current is shown in Figure $\mathbf{C}$, which represents the velocity and direction of the current as observed in the Hudson River off Fort Washington on July 22, 1922.

In Figure $\mathrm{C}$ the upper curve represents the velocity of the current in knots, flood being plotted above the axis of $\mathrm{X}$ and ebb below the axis. The velocity curve represents approximately the form of the cosine curve. The maximum velocity of the flood current is called the strength of flood and the maximum ebb velocity the strength of ebb. The knot is the unit generally used for measuring the velocity of tidal currents and represents a velocity of 1 nautical mile per hour. Knots may be converted into statute miles per hour by multiplying by 1.15 , or into feet per second by multiplying by 1.69 .

The lower curve of Figure $\mathrm{C}$ is the direction curve of the current, the direction being given in degrees, north being $0^{\circ}$, east $90^{\circ}$, south $180^{\circ}$, and west $270^{\circ}$. The directions are magnetic and represent the direction of the current as derived from hourly observations. During the period of flood the direction curve shows that the current was running practically in the same direction all the time, making an abrupt shift of about $180^{\circ}$ to the opposite direction during the period of slack water. For the ebb period the direction curve likewise shows the current to have been running in approximately the same direction with an abrupt change of about $180^{\circ}$ during slack.

\section{ROTARY TIDAL CURRENTS}

Offshore the tidal currents are generally not of the rectilinear or reversing type. Instead of flowing in the same general direction during the entire period of the flood and in the opposite direction during the ebb, the tidal currents offshore change direction continually. Such currents are therefore called rotary currents. An example of this type of current is shown in Figure D, which represents the velocity and direction of the current at the beginning of each hour of the afternoon on September 24, 1919, at Nantucket Shoals Light Vessel, stationed off the coast of Massachusetts.

The current is seen to have changed its direction at each hourly observation, the rotation being in the direction of movement of the hands of a clock, or from north to south by way of east, then to north again by way of west. In a period of about 12 hours it is seen that the current has veered completely round the compass.

It will be noted that the ends of the radii vectores, representing the velocities and directions of the current at the beginning of each hour, define a somewhat irregular ellipse. If a number of observations are averaged, eliminating accidental errors and temporary meteorological disturbances, the regularity of the curve is considerably increased. The average period of the cycle is, from a considerable number of observations, found to be $12^{\mathrm{h}} 25^{\mathrm{m}}$. In other words, the current day, like the tidal day, is $24^{\mathrm{h}} 50^{\mathrm{m}}$ in length.

A characteristic feature of the rotary current is the absence of slack water. Although the current generally varies from hour to hour, this variation from greatest current to least current and back again to greatest current does not give rise to a period of slack water. When the velocity of the rotary tidal current is least, it is known as the minimum current, and when it is greatest it is known as the maximum current. The minimum and maximum velocities of the rotary current are thus related to each other in the same way as slack and strength of the rectilinear current, a minimum velocity following a maximum velocity by an interval of about three hours and being followed in turn by another maximum after a further interval of three hours.

\section{VARIATIONS IN STRENGTH OF CURRENT}

Tidal currents exhibit changes in the strength of the current that correspond closely with the changes in range exhibited by tides. The strongest currents come with the spring tides of full and new moon and the weakest currents with the neap tides of the moon's first and third quarters. Likewise, perigean tides are accompanied by strong currents and apogean tides by weak currents; and when the moon has considerable variation, the currents, like the tides, are characterized by diurnal inequality. 
As related to the moon's changing phases, the variation in the strength ${ }^{-}$of the current from day to day is approximately proportional to the corresponding change in the range of the tide. The moon's changing distance likewise brings about changes in the velocity of the strength of the current which is approximately proportional to the corresponding change in the range of the tide; but in regard to the moon's changing declination, tide and current do not respond alike, the diurnal variation in the tide at any place being generally greater than the diurnal variation in the current.
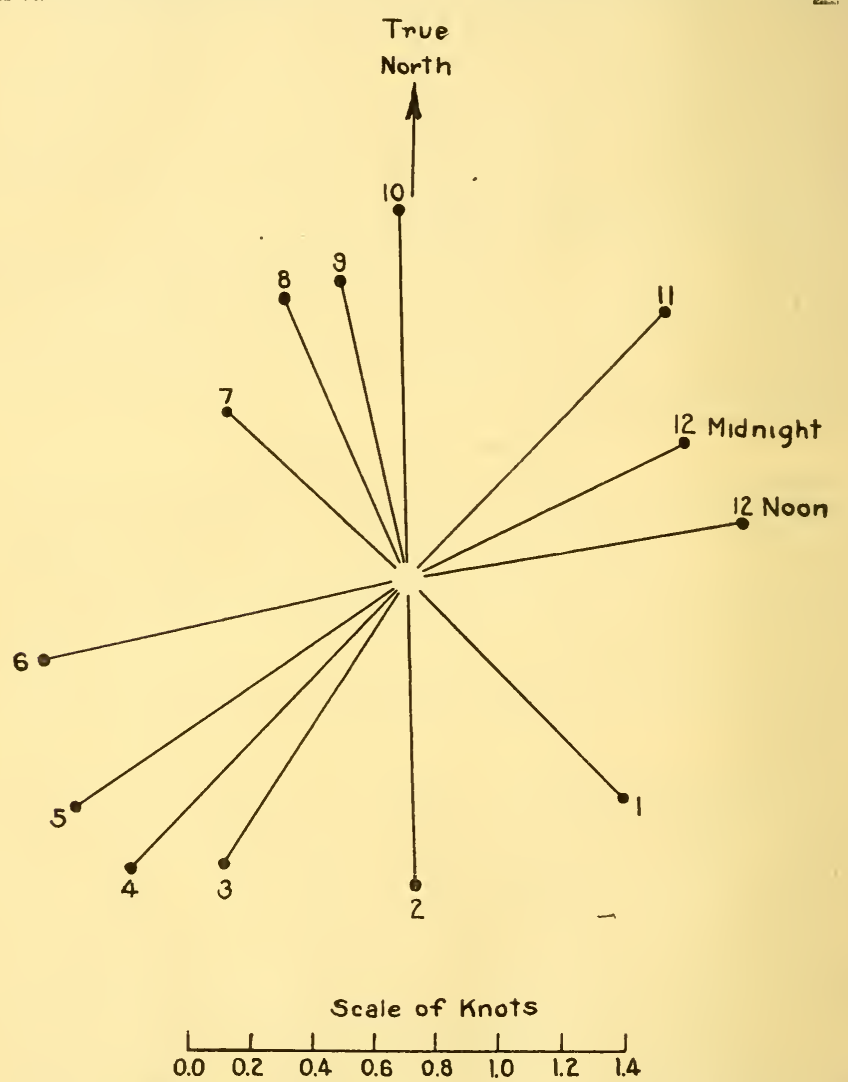

FIG. D.-Rotary current, Nantucket Shoals Light Vessel, afternoon of September 24, 1919

The relations subsisting between the changes in the velocity of the current at any given place and the range of the tide at that place may be derived from general considerations of a theoretical nature. Variations in the current that involve semidiurnal components will approximate corresponding changes in the range of the tide; but for variations involving diurnal components the variation in the current is about half that in the tide. 


\section{RELATION OF TIME OF CURRENT TO TIME OF TIDE}

In simple wave motion the times of slack and strength of current bear a constant and simple relation to the times of high and low waters. In a progressive wave the time of slack water comes, theoretically, exactly midway between high and low water and the time of strength at high and low water; in a stationary wave slack comes at the times of high and low water, while the strength of current comes midway between high and low water.

The progressive-wave movement and the stationary-wave movement are the two principal types of tidal movements. A progressive wave is one whose crest advances, so that in any body of water that sustains this type of tidal movement the times of high and low water progress from one end to the other. A stationary wave is one that oscillates about an axis, high water occurring over the whole area on one side of this axis at the same instant that low water occurs over the whole area on the other side of the axis.

The tidal movements of coastal waters are rarely of simple wave form; nevertheless, it is very convenient in the study of currents to refer the times of current to the times of tide. And where the diurnal inequality in the tide is small, as is the case on the Atlantic coast, the relation between the time of current and the time of tide is very nearly constant. This is brought out in Figure E, which represents the tidal and current curves in New York Harbor for October 9,1919 , the current curve being the dashed-line curve, representing the velocities

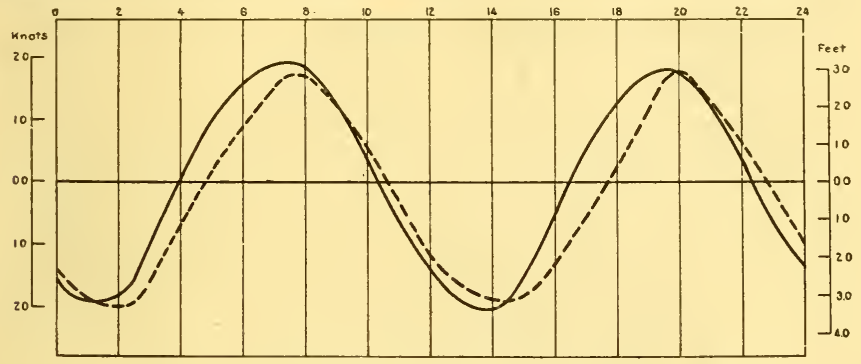

Fig. E.-Tide and current curves, New York Harbor, October 9, 1919

of the current at a station in Upper Bay, and the tide curve being the full-line curve, representing the rise and fall of the tide at Fort Hamilton, on the eastern shore of the Narrows.

The diagrams of Figure $\mathrm{E}$ were drawn by plotting the heights of the tide and the velocities of the current to the same time scale and to such velocity and height scales as will make the maximum ordinates of the two curves approximately equal. The time axis or axis of $\mathrm{X}$ represents the line of zero velocity for the currents and of mean sea level for the tide, the velocity of the current being plotted in accordance with the scale of knots on the left, while the height of the tide reckoned from mean sea level was plotted in accordance with the scale in feet on the right.

From Figure $\mathrm{E}$ it is seen that the corresponding features of the tide and current in New York Harbor bear a very nearly constant time relation to each other, and this constancy in time relation of tides and currents is characteristic of tidal waters in which the diurnal inequality is small. This permits the times of slack and of strength of current to be referred to the times of high and low water. Thus, from Figure $\mathrm{E}$ we find strength of ebb occurred about 0.6 hour after the time of low water, both morning and afternoon; slack before flood occurred 2.2 hours before high water; strength of flood 0.4 hour after high water; slack before ebb 3.0 hours before low water. In this connection, however, it is to be noted that the time relations between the various phases of tide and current are subject to the disturbing effects of wind and weather.

Apart from the disturbing effect of nontidal agencies, the time relations between tide and current are subject to variation in regions where the tide exhibits considerable diurnal inequality, as, for example, on the Pacific coast of the United States. This variation is due to the fact, previously mentioned, that

$$
81772-28-8
$$


the diurnal inequality in the current at any given place is, in general, only about half as great as that in the tide. This brings about differences in the corresponding features of tide and current as between morning and afternoon. However, in such cases it is frequently possible to refer the current at a given place to the tide at some other place with comparable diurnal inequality.

\section{EFFECT OF NONTIDAL CURRENT}

The tidal current is subject to the disturbing influence of nontidal currents which affect the regularity of its occurrence as regards time, velocity, and direction. In the case of the rectilinear current the effect of a steady nontidal current is, in general, to make both the periods and the velocities of flood and ebb unequal and to change the times of slack water but to leave unchanged the times of flood and ebb strengths. This is evident from a consideration of Figure $\mathrm{F}$, which represents a simple rectilinear tidal current, the time axis of which is the line $A B$, flood velocities being plotted above the line and ebb velocities below.

When unaffected by nontidal currents, the periods of flood and ebb are, in general, equal as represented in the diagram, and slack water occurs regularly three hours and six minutes after the times of flood and ebb strengths. But if we assume a steady nontidal current introduced which has, in the direction of the tidal current, a velocity component represented by the line $C D$, it is evident

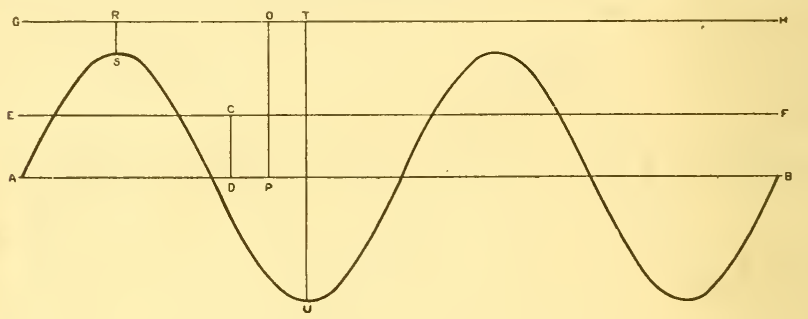

Fig. F.-Effect of nontidal current on tidal current

that the strength of ebb will be increased by an amount equal to $C D$, while the flood strength will be decreased by the same amount. The current conditions may now be completely represented by drawing, as a new axis, the line $E F$ parallel to $A B$ and distant from it the length of $C D$.

Obviously, if the velocity of the nontidal current exceeds that of the tidal current at the time of strength, the tidal current will be completely masked and the resultant current will set at all times in the direction of the nontidal current. Thus, if in Figure $\mathrm{F}$ the line $O P$ represents the velocity component of the nontidal current in the direction of the tidal current, the new axis for measuring the velocity of the combined current at any time will be the line $G O$ and the current will be flowing at all times in the ebb direction. There will be no slack waters; but at periods 6 hours 12 minutes apart there will occur minimum and maximum velocities represented, respectively, by the lines $R S$ and $T U$.

In so far as the effect of the nontidal current on the direction of the tidal current is concerned, it is only necessary to remark that the resultant current will set in a direction which at any time is the resultant of the tidal and nontidal currents at that time. This resultant direction and also the resultant velocity may be determined either graphically by the parallelogram of velocities or by the usual trigonometric computations.

\section{VELOCITY OF TIDAL CURRENTS AND PROGRESSION OF THE TIDE}

In the tidal movement of the water it is necessary to distinguish clearly between the velocity of the current and the progression or rate of advance of the tide. In the former case reference is made to the actual speed of a moving particle, while in the latter case the reference is to the rate of advance of the tide phase or the velocity of propagation of wave motion, which generally is many times greater than the velocity of the current. 
It is to be noted that there is no necessary relationship bctween the velocity of the tidal current at any place and the rate of advance of the tide at that place. In other words, if the rate of advance of the tide is known we can not from that alone infer the velocity of the current, nor vice versa. The rate of advance of the tide in any given body of water depends on the type of tidal movement. In a progressive wave the tide moves approximately in accordance with the formula $r=\sqrt{g d}$ in which $r$ is the rate of advance of the tide, $g$ the acceleration of gravity, and $d$ the depth of the waterway. In stationary-wave movement, since high or low water occurs at very nearly the same time over a considerable area, the rate of advance is theoretically very great; but actually there is always some progression present, and this reduces the theoretical velocity considerably.

The velocity of the current, or the actual speed with which the particles of water are moving past, any fixed point, depends on the volume of water that must pass the given point and the cross-section of the chammel at that point. The velocity of the current is thus independent of the rate of advance of the tide.

\section{DiSTANCE TRAVELED BY A PARTICLE IN A TIDAL CXCLE}

In a rectillinear current the distance traveled by the water particles or by any object floating in the water is obviously equal to the product of the time by the average velocity during this interval of time. To determine the average velocity of the tidal current for any desired interval several methods may be used.

If the curve of the tidal current has been plotted, the average velocity may be derived as the mean of a number of measurements of the velocity made at frequent intervals on the curve; as, for example, every 10 or 15 minutes. From the current curve the average velocity mav also be determined by deriving the mean ordinate of the curve by use of the planimeter. For a full tidal cycle of flood or ebb, however, since the current curve generally approximates the cosine curve, the simplest method consists in making use of the well-known ratio of the mean ordinate of the cosine curve to the maximum ordinate which is $2 \div \pi$, or 0.6366 .

The latter method has another advantage in that the velocity of the tidal current is almost invariably specified by its velocity at the time of strength, which corresponds to the maximum ordinate of the cosine curve; hence, the average velocity of the tidal current for a flood or ebb cycle is given immediately as the product of the strength of the current by 0.6366 . And though this method is only approximate, since the curve of the current may deviate more or less from the cosine curve, in general the results will be sufficiently accurate for all practical purposes. For a normal flood or ebb period of 6.2 hours the distance a tidal current with a velocity at strength of $1 \mathrm{knot}$ will carry a floating object is, in nautical miles, $0.6366 \times 6.2=3.95$, or 24,000 feet.

\section{DURATION OF SLACK}

In the change of direction of flow from flood to ebb, and vice versa, the tidal current goes through a period of slack water or zero velocity. Obviously, this period of slack is but momentary, and graphically it is represented by the instant when the current curve cuts the zero line of velocities. For a brief period each side of slack water, however, the current is very weak, and in ordinary usage "slack water" denotes not only the instant of zero velocity but also the period of weak current. The question is therefore frequently raised, How long does slack water last?

To give slack water in its ordinary usage a definite meaning, we may define it to be the period during which the velocity of the current is less than onetenth of a knot. Velocities less than one-tenth of a knot may generally be disregarded for practical purposes, and such velocities are, moreover, difficult to measure either with float or with current meter. For any given current it is now a simple matter to determine the duration of slack water, the current curve furnishing a ready means for this determination.

In general, regarding the current curve as approximately a sine or cosine curve, the duration of slack water is a function of the strength of current-the stronger the current the less the duration of slack-and from the equation of the sine curve we may easily compute the duration of slack water for currents of various strengths. For the normal flood or ebb cvcle of $6^{\mathrm{h}} 12.6^{\mathrm{m}}$ we may write the equation of the current curve $y=A \sin 0.4831 t$, in which $A$ is the velocity of the current in knots at time of strength, 0.4831 the angular velocity in degrees per minute, and $t$ is the time in minutes from the instant of zero velocity. 
Setting $y=0.1$ and solving for $t$ (this value of $t$ giving half the duration of slack), we get for the duration of slack the following values: For a current with a strength of 1 knot, slack water is 24 minutes; for currents of 2 knots strength, 12 minutes; 3 knots, 8 minutes; 4 knots, 6 minutes; 5 knots, 5 minutes: 6 knots, 4 minutes; 8 knots, 3 minutes; 10 knots, $21 / 3$ minutes.

\section{HARMONIC CONSTANTS}

The tidal current, like the tide, may be regarded as the resultant of a number of simple harmonic movements, each of the form $y=A \cos (a t+a)$ : hence, tidal currents may be analyzed in a manner analagous to that used in tides and the harmonic current constants derived. These constants permit the characteristies of the currents to be determined in the same manner as the tidal harmonic constants and they may also be used in the prediction of the times of slack and the times and velocities of the strength of current.

It can easily be shown that in coastal or inland tidal waters the amplitudes of the various current components are related to each other, not as the amplitudes of the corresponding tidal components, but as these latter multiplied by their respective speeds; that is, in any given harbor, if we denote the various components of the current by primes and of the tide by double primes, we have

$$
\mathrm{M}_{2}^{\prime}: \mathrm{S}_{2}^{\prime}: \mathrm{N}_{2}^{\prime}: \mathrm{K}_{1}^{\prime}: \mathrm{O}_{1}^{\prime}=m_{2} \mathrm{M}^{\prime \prime}{ }_{2}: s_{2} \mathrm{~S}_{2}^{\prime \prime}: n_{2} \mathrm{~N}^{\prime \prime}{ }_{2}: k_{1} \mathrm{~K}^{\prime \prime}{ }_{1}: o_{1} \mathrm{O}^{\prime \prime}{ }_{1}
$$

where the small italic letters represent, respectively, the angular speed of the corresponding components. This shows at once that the diurnal inequality in the currents should be approximately half that in the tide.

\section{MEAN VALUES}

In the nonharmonic analysis of current observations it is customary to refer the times of slack and strength of current to the times of high and low water of the tide at some suitable place, generally near by. In this method of analysis the time of current determined is in effect reduced to approximate mean value, since the changes in the tidal current from day to day may be taken to approximate the corresponding changes in the tide; but the velocity of the current as determined from a short series of observations must be reduced to a mean value.

In the ordinary tidal movement of the progressive or stationary wave types the change in the strength of the current from day to day may be taken approximately the same as the variation in the range of the tide. Hence, the velocity of the current from a short series of observations may be corrected to a mean value by multiplying by a factor equal to the mean range of the tide divided by the range for the period of observations. It is to be noted that in this method of reducing to a mean value any nontidal currents must first be eliminated and the factor applied to the tidal current alone. This may be done by taking the strength of the tidal current as the half sum of the flood and ebb strengths for the period in question.

In some places the current, while exhibiting the characteristic features of the tidal current, is in reality a hydraulic current due to differences in head at the ends of a strait connecting two independent tidal bodies of water. East River and Harlem River in New York Harbor and Seymour Narrows in British Columbia are examples of such straits, and the currents sweeping through these waterways are not tidal currents in the true sense, but hydraulic currents. The velocities of such currents vary as the square root of the head, and hence in reducing the velocities of such currents to a mean value the factor to be used is the square root of the factor used for ordinary tidal currents. 


\section{PUBLICATIONS BY THE UNITED STATES COAST AND GEODETIC SURVEY RELATING TO TIDES AND CUR- RENTS}

TIDE AND CURRENT TABLES

Price

$\$ 0.75$

Tide Tables, United States and Foreign Ports

United States and Foreign Ports)

Tide Tables, Pacific Coast, North America, Eastern Asia and Island Group (reprinted from Tide Tables, United States and Foreign Ports) - -

Tide Table, New York Harbor..... Current Tables, Atlantic Coast, North America................... Current Tables, Pacific Coast, North America and Philippine Islands...Current Diagram, Nantucket and Vineyard Sounds............. Current Diagram, Chesapeake Bay.

The tide tables contain the predicted times and heights of the tide for each day in the year at a number of principal ports and tidal differences and constants for many other places. The current tables give the predicted currents for each day in the year at a number of principal ports and current differences and constants for many other stations. The current diagrams are reproductions on an enlarged scale of similar diagrams contained in the current tables.

The tide and current tables are issued in advance annually and may be purchased at the office of the United States Coast and Geodetic Survey or from any of its agencies.

\section{TIDAL BENCH MARKS}

Special Publication No. 83 (Serial 193), Tidal Bench Marks, State of New York, 1922 Special Publication No. 119 (Serial 320), Tidal Bench Marks, District of Columbia, 1925

Special Publication No. 128 (Serial 370), Tidal Bench Marks, State of Rhode Island, 1927 . Special Publication No. 136. Tidal Bench Marks, State of Connecticut, $1927 \ldots \ldots$ Special Publication No. 141. Tidal Bench Marks, State of California, 1928

HARBOR PUBLICATIONS

Special Publication No. 111 (Serial 285), Tides and Currents in New

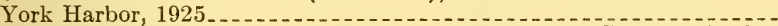
Special Publication No. 115 (Serial 311), Tides and Currents in San Francisco Bay, 1925

Special Publication No. 123 (Serial 336), Tides and Currents in Delaware Bay and River, 1926

Special Publication No. 127 (Serial 364), Tides and Currents in Southeast - Alaska, 1926 Special Publication No. 142. Tides and Currents in Boston Harbor, 1928

Special Publication No. - Tides and Currents in Portsmouth Harbor (in preparation).

The above harbor publications aim to give in detail the results of all the observational data available for each harbor covered.

\section{MISCELLANEOUS PUBLICATIONS}

The Gulf Stream, by J. E. Pillsbury. Published as appendix to the Annual Report of the United States Coast and Geodetic Survey for the year 1890. This report is no longer available for distribution but may be consulted in any of the larger libraries.

Manual of Tides, by R. A. Harris. This publication was issued in separate parts as appendices to the Annual Reports of the United States Coast and Geodetic Survey for the years 1894, 1897, 1900, 1904, and 1907. These reports are no longer available for distribution but may be consulted in any of the larger libraries.

Arctic Tides, 1911 
Special Publication" No. 23, United States Coast and Geodetic Survey. Description of its work, methods, and organization. Includes illustrated sections on tides and currents. This publication can be obtained free of charge from the office of the United States Coast and Geodetic Survev.

Special Publication No. 32 (Serial 16), Description of the United States Coast and Geodetic Survey Tide-Predicting Machine No. 2, 1915

Special Publication No. 41 (Serial 60), Use of Mean Sea Level as the Datum for Elevations, 1917

Special Publication No. 98 (Serial 244), A Manual of the Harmonic Analysis and Prediction of Tides, 1924

Serial 2so, Tidal and Current Surveys, Methods, Instruments, and Purposes, 1924. This is a small pamphlet which may be obtained free of charge from the office of the United States Coast and Geodetic Survey.

Special Publication No. 113 (Serial 300), Portable Automatic Tide Gauge, 1925

Special Publication No. 121 (Serial 330), Coastal Currents Along the Pacific Coast of the United States, 1926

Special Publication No. 124 (Serial 346), Instructions for Tidal Current Survevs, 1926

Serial 351, Tide and Current Investigations of the Coast and Geodetic Survey, 1926

Special Publication No. 135, Tidal Datum Planes, 1927

pecial Publication No. 139, Instructions for Tide Observations, 1928_ . 20

Except as otherwise noted, all the above publications are for sale by the Superintendent of Documents, Government Printing Office, Washington, D. C., to whom remittance should be sent. 


\section{N D E X}

Page

A ges of tide 14,100

A nnual variation in tide

A pondix

Bench marks

Boston (central portion) ....... 45

Boston Light, Little Brewster Island .... 43

Boston Navy Yard............ 4, 5, 6, 7, 8, 9, 44

Brookline.

Cambridge.

Charlestown

Chelsea Creek entrance ................. 44

Crow Point, Hingham Harbor entrance.

Georges Island

Lovells Island.

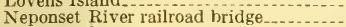

Nut Island.

South Boston

Weymouth Fore River bridge....................

Boston City base

Boston Harbor:

Adjusted tidal data

18,67

Condensed current data.

Temperature and density of sea water $\ldots 28,90$

Tidal data, 1817-1926 ............... 18, 65

Boston Light Vessel:

Current observations .................. 24

Harmonic analysis _...... 25,81

Set of nontidal current $\ldots \ldots \ldots \ldots . \ldots 25,80$

Tidal currents............ 25, 79

Wind reduction $\ldots \ldots \ldots \ldots$

Boston low-water datum................ 41

Boston Navy Yard:

Ages of tide.

A pogean range

Bench marks.

Box gauge

$4,5,6,7,8,9,44$

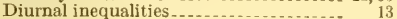

Diurnal ranges

Dry Dock No. 1

$3,6,7,8,9$

Duration of rise of tide

11,50

Expansion of seams in dry dock _.. $3,8,9$

Extreme high waters....... 52

Extreme low waters ................ 54

Extreme ranges.

Greenwich inter vals

Harmonic constants

High and low water heig

Letters from observer, 1857.

3

Leveling connections

Mean rise interval

Mean sea level.

Mean tide level

Neap range.

Neap.tide level

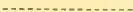

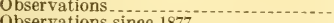

Observations since $1877 \ldots \ldots \ldots \ldots$
Observers

Perigean range

Porcelain tide staff

Pressure or glycerin gauge

Range of tide

Reduction of records

Repairs to dry dock

Self-registering tide gauge -

Self-registering tide gauge

Spring range.

Spring tide level.

Summary, ranges and inequalities

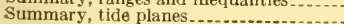

Boston Nay y Yard-Continued.

Summary, time relations.

Temperature of sea water $\ldots \ldots \ldots \ldots .28,90$

Tide scale . .

Tide staff.

Tropic lunitidal intervals

Tropic ranges

Commonwealth Pier No. 5 :

Annual variation............... 15

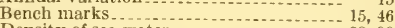

Density of sea water.................. 28, 90

Difference between mean tide level and mean sea level

Duration of rise of tide..................... 23

Extreme high waters. . .

Extreme low waters.

Float well ................ 14

Harmonic constants _._. 17,64

High and low water heights _.......

Lunitidal intervals ............. 17,56,57

Mean sea level $\ldots \ldots \ldots, 62$

Mean tide level ............................ 61

Monthly means. 15

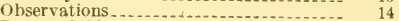

Range of tide

Reduction of records

Summary of ranges and inequalities.... 63

Summary of tide planes............... 17,63

Surnmary of time relations .............. 62

Temperature of sea water ............ 28,90

Tide staff...................................... 15

Current:

Definitions. _._.

Duration of slack

General characteristics _._. 106

Harmonic analysis ........... 23, 25, 79, 81

Mean current hour

Mean values.

Moon Head .

Nontidal . . . .

Rectilinear

Relation to tide.

Rotary

The Narrows. . .

Variation in strength........ 107

Velocity ......... 110

Wind reduction..... 25,80

Current eharts...................

Current data:

Condensed data $\ldots \ldots \ldots \ldots$ 27, 89

Observations, $1847,1848 \ldots \ldots \ldots \ldots \ldots . \ldots 18,68$

Observations, $1860,1861,1863 \ldots \ldots \ldots$

Observations, 1902 .................. 21, 72

Observations, 1926_....... 21, 73

Observations, Boston Light Vessel...... 24, 79

Summary of surface currents ........... 25,82

Current meter............................. 21, 22

Current pole

Boston eity base

Boston low-water datum ............ 41

Navy yard datum................... 42

Sea-level datum

Density of sea water.... 28,90

Difference, mean sea level and mean tide

level.

Distance traveled in a tidal cycle $\ldots 2 \ldots$

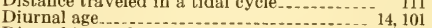

Diurnal age
Diurnal inequality ........... 14,101

Diurnal range $\ldots \ldots \ldots 13$

Dry Dock No. 1

Expansion of seams........

Repairs . . 
Page

Duration of rise of tide $11,50,57,65,67$

Duration of slack water

111

Extreme high water.

Extreme low water

Extreme range....

Glycerin gauge.

Greenwich intervals

Half tide level. See Mean tide level.

Harmonic analysis:

Current

$23,25,79,81,112$

Tides.

$14,17,64,103$

High water

Inequality. See Diurnal inequality.

Intervals. See Lunitidal intervals.

Introduction

$11,50,51,58$

Low water

Mean current hour

Mean rise interval

10

Mean sea level ...................... $14,41,61,62,104$

Mean tide level.................... 14, $56,61,62,105$

Mean values......................... 105, 112

Narrows, The

27
26

Navy yard. See Boston Navy Yard.

Navy yard datum

Neap range.

Neap tide level

$12,17,100$

4, 17

Nontidal current

110

Perigean range

14

Pettersson current meter

Phase age

Porcelain tide staff

Price current meter

Progression of the tide.

Publications relating to tides and currents..

Range of tide:

Descriptive $\ldots \ldots \ldots \ldots \ldots \ldots . . . \ldots \ldots 12,15,17,18,100$ Tables _.................... $51,59,63,65,67$

Rectilinear tidal current

Relation of current to tide........ 109

Rotary tidal currents....................... 107

Sea-level datum................ 41

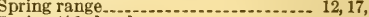

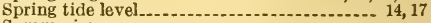
Summaries:

Adjusted tidal data........... 67

Condensed current data $\ldots \ldots \ldots$

Ranges and inequalities................ 63

Tide planes.............................. 63

Time relations 62

Surface currents

Tables.

Tidal data:

Adjusted data, Boston Harbor......... 18,67

Boston Harbor, miscellaneous series.... 18, 65

Boston Navy Yard................... 2, 50, 62

Commonwealth Pier No. $5 \ldots$

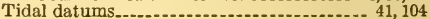
Tide:

Definitions............ 98

General characteristics.................. 98

Mean values........................... 105

Relation to current

Types

Tide planes........

Tide-producing forces........................ 99

Tropic intervals ............ 10

Tropic range........... 13

Variation in range

Velocity of tidal current.......

Wind reduction. 


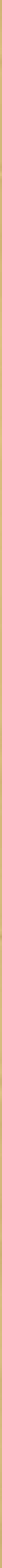


